\title{
EVALUATION OF NATURAL ATTENUATION PROCESSES FOR TRICHLOROETHYLENE AND TECHNETIUM-99 IN THE NORTHEAST AND NORTHWEST PLUMES AT THE PADUCAH GASEOUS DIFFUSION PLANT PADUCAH, KENTUCKY
}

\author{
J. L. Clausen \\ Environmental Management and Enrichment Facilities \\ Engineering and Technical Support Division \\ N. C. Sturchio \\ L. J. Heraty \\ L. Huang \\ T. Abrajano \\ Argonne National Laboratory \\ Lockheed Martin Energy Systems, Inc. \\ Prepared for \\ Environmental Management and Enrichment Facilities \\ Kevil, Kentucky 42053 \\ Managed by \\ LOCKHEED MARTIN ENERGY SYSTEMS, INC. \\ for the \\ U.S. DEPARTMENT OF ENERGY \\ Under Contract No. DE-AC05-760R00001
}




\section{DISCLAIMER}

This report was prepared as an account of work sponsored by an agency of the United States Government. Neither the United States Government nor any agency thereof, nor any of their employees, make any warranty, express or implied, or assumes any legal liability or responsibility for the accuracy, completeness, or usefulness of any information, apparatus, product, or process disclosed, or represents that its use would not infringe privately owned rights. Reference herein to any specific commercial product, process, or service by trade name, trademark, manufacturer, or otherwise does not necessarily constitute or imply its endorsement, recommendation, or favoring by the United States Government or any agency thereof. The views and opinions of authors expressed herein do not necessarily state or reflect those of the United States Government or any agency thereof. 


\section{DISCLAIMER}

Portions of this document may be illegible in electronic image products. Images are produced from the best available original document. 


\section{PREFACE}

This final report for evaluation of Natural Attenuation in the Northwest and Northeast Plumes at the Paducah Gaseous Diffusion Plant (PGDP) was prepared in accordance with requirements under the Comprehensive Environmental Response, Compensation, and Liability Act (CERCLA) and the Resource Conservation and Recovery Act (RCRA) and applicable state laws for investigating areas of concern.

Information generated from this study will provide data needed to determine if Natural Attenuation is a viable process for aquifer restoration at PGDP. 


\section{CONTENTS}

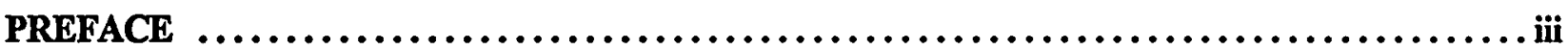

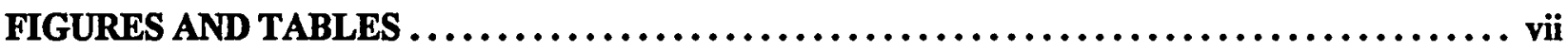

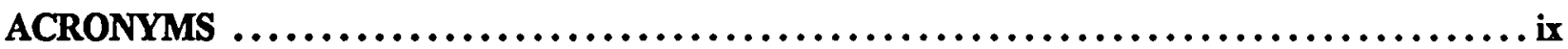

EXECUTIVE SUMMARY $\ldots \ldots \ldots \ldots \ldots \ldots \ldots \ldots \ldots \ldots \ldots \ldots \ldots \ldots \ldots \ldots \ldots \ldots$

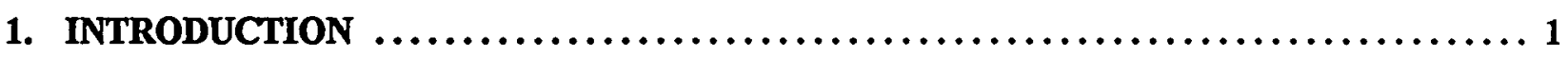

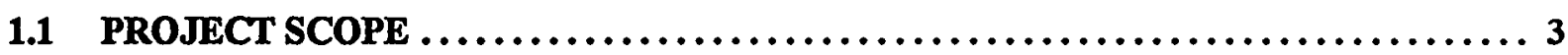

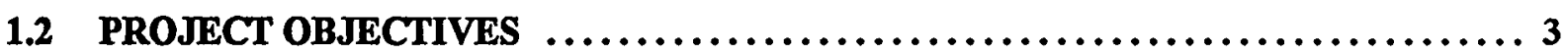

1.3 REGULATORY OVERVIEW $\ldots \ldots \ldots \ldots \ldots \ldots \ldots \ldots \ldots \ldots \ldots \ldots \ldots \ldots \ldots \ldots \ldots$

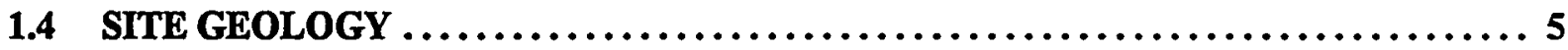

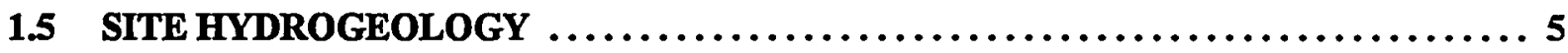

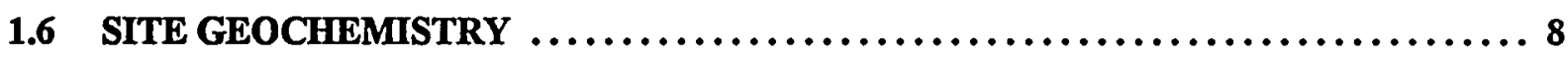

2. GENERAL OVERVIEW OF NA $\ldots \ldots \ldots \ldots \ldots \ldots \ldots \ldots \ldots \ldots \ldots \ldots \ldots \ldots \ldots \ldots \ldots \ldots$

2.1 PROTOCOL FOR NA EVALUATION $\ldots \ldots \ldots \ldots \ldots \ldots \ldots \ldots \ldots \ldots \ldots \ldots \ldots \ldots$

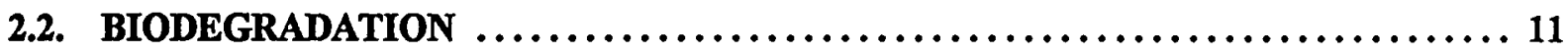

2.2.1 Electron Acceptor Reactions $\quad \ldots \ldots \ldots \ldots \ldots \ldots \ldots \ldots \ldots \ldots \ldots \ldots \ldots \ldots, \ldots \ldots$

2.2.2 Electron Donor Reactions $\ldots \ldots \ldots \ldots \ldots \ldots \ldots \ldots \ldots \ldots \ldots \ldots \ldots \ldots \ldots, 15$

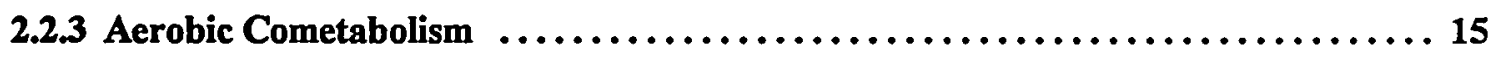

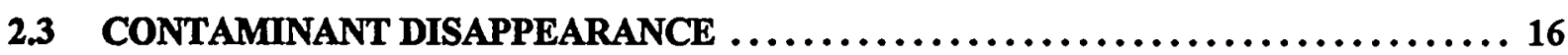

2.4 LOSS OF ELECTRON ACCEPTORS AND ACCUMULATION OF DEGRADATION PRODUCTS FOR CHLORINATED SOLVENTS $\ldots \ldots \ldots \ldots \ldots \ldots \ldots \ldots \ldots \ldots, 17$

2.5 ADDITIONAL MONITORING PARAMETERS $\ldots \ldots \ldots \ldots \ldots \ldots \ldots \ldots \ldots \ldots, 18$ 
3. FIELD AND ANALYTICAL METHODS $\ldots \ldots \ldots \ldots \ldots \ldots \ldots \ldots \ldots \ldots \ldots \ldots \ldots, 18$

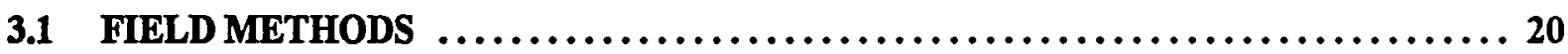

3.2 ANALYTICAL METHODS $\ldots \ldots \ldots \ldots \ldots \ldots \ldots \ldots \ldots \ldots \ldots \ldots \ldots \ldots \ldots \ldots . \ldots \ldots$

4. QUALITY ASSURANCE/QUALITY CONTROL $\ldots \ldots \ldots \ldots \ldots \ldots \ldots \ldots \ldots \ldots \ldots \ldots \ldots$

4.1 GROUND WATER SAMPLING $\ldots \ldots \ldots \ldots \ldots \ldots \ldots \ldots \ldots \ldots \ldots \ldots \ldots \ldots \ldots \ldots, 23$

4.2 ANALYTICAL PROTOCOL $\ldots \ldots \ldots \ldots \ldots \ldots \ldots \ldots \ldots \ldots \ldots \ldots \ldots \ldots, 24$

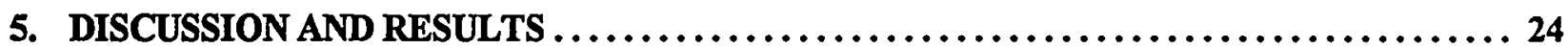

5.1 GENERAL GROUNDWATER GEOCHEMISTRY $\ldots \ldots \ldots \ldots \ldots \ldots \ldots \ldots \ldots \ldots$

5.2 CONTAMINANT GEOCHEMISTRY $\ldots \ldots \ldots \ldots \ldots \ldots \ldots \ldots \ldots \ldots \ldots \ldots \ldots, 25$

5.3 ISOTOPE GEOCHEMISTRY $\ldots \ldots \ldots \ldots \ldots \ldots \ldots \ldots \ldots \ldots \ldots \ldots \ldots \ldots \ldots \ldots \ldots \ldots, 30$

5.4 GASEOUS GEOCHEMISTRY $\ldots \ldots \ldots \ldots \ldots \ldots \ldots \ldots \ldots \ldots \ldots \ldots \ldots \ldots \ldots \ldots, 31$

5.5 EVALUATION OF TCE BIODEGRADATION $\ldots \ldots \ldots \ldots \ldots \ldots \ldots \ldots \ldots \ldots \ldots \ldots \ldots \ldots$

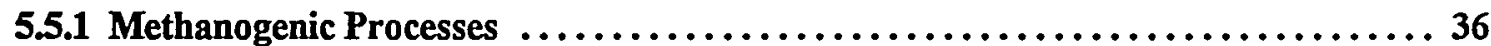

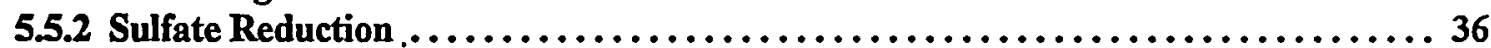

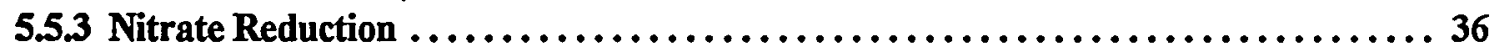

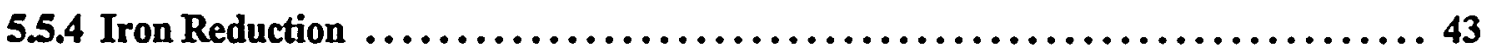

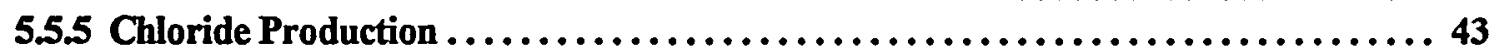

5.6 RADIOCHEMISTRY $\ldots \ldots \ldots \ldots \ldots \ldots \ldots \ldots \ldots \ldots \ldots \ldots \ldots \ldots \ldots \ldots \ldots, 48$

5.7 QUANTIFICATION OF NATURAL ATTENUATION $\ldots \ldots \ldots \ldots \ldots \ldots \ldots \ldots \ldots, 48$

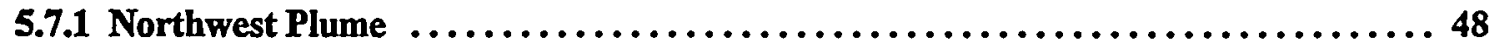

5.7 .2 Northeast Plume $\ldots \ldots \ldots \ldots \ldots \ldots \ldots \ldots \ldots \ldots \ldots \ldots \ldots \ldots \ldots \ldots \ldots, 53$

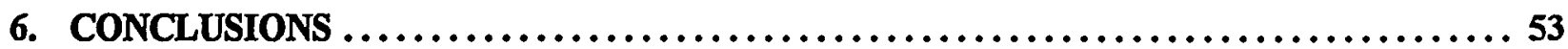

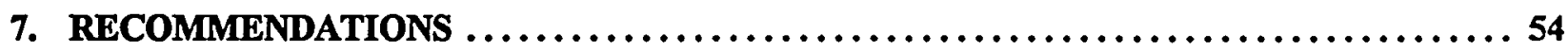

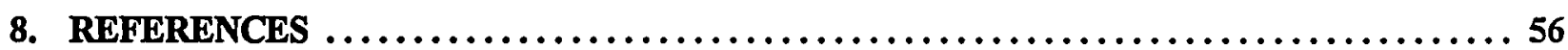

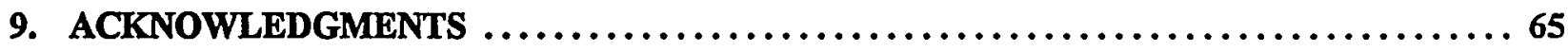


CONTENTS (Cont.)

Page

APPENDIX A (NATURAL ATTENUATION STUDY DATA) $\ldots \ldots \ldots \ldots \ldots \ldots \ldots \ldots \ldots$ A-1

APPENDIX B (HISTORICAL MONITORING WELL DATA) $\ldots \ldots \ldots \ldots \ldots \ldots \ldots \ldots$. B-1 


\section{LIST OF FIGURES AND TABLES}

Eigure Number

Page

1. The location of PGDP $\ldots \ldots \ldots \ldots \ldots \ldots \ldots \ldots \ldots \ldots \ldots \ldots \ldots \ldots \ldots \ldots \ldots \ldots \ldots \ldots$

2. The location of sample collection points within the Northeast and Northwest Plumes $\ldots \ldots \ldots 4$

3. Block diagram of PGDP geology $\ldots \ldots \ldots \ldots \ldots \ldots \ldots \ldots \ldots \ldots \ldots \ldots \ldots \ldots \ldots \ldots \ldots \ldots$

4. Fence diagram of PGDP lithology $\ldots \ldots \ldots \ldots \ldots \ldots \ldots \ldots \ldots \ldots \ldots \ldots \ldots \ldots \ldots \ldots \ldots$

5. Potentiometric map for the RGA during May $1997 \ldots \ldots \ldots \ldots \ldots \ldots \ldots \ldots \ldots \ldots \ldots$

6. Reductive dechlorination pathway of TCE $\ldots \ldots \ldots \ldots \ldots \ldots \ldots \ldots \ldots \ldots \ldots \ldots \ldots \ldots \ldots$

7. Terminal electron acceptor patterns for reductive dechlorination $\ldots \ldots \ldots \ldots \ldots \ldots \ldots \ldots 14$

8. The relationship of dissolved oxygen to bicarbonate $\ldots \ldots \ldots \ldots \ldots \ldots \ldots \ldots \ldots \ldots \ldots$

9. The relationship of dissolved oxygen to nitrogen $\ldots \ldots \ldots \ldots \ldots \ldots \ldots \ldots \ldots \ldots \ldots \ldots$

10. The level of TCE and ${ }^{99} \mathrm{Tc}$ within the Northwest Plume at MW66 over time ........... 28

11. The level of TCE and ${ }^{99} \mathrm{Tc}$ within the Northwest Plume at $\mathrm{R2}$ over time ............. 29

12. The relationship of bicarbonate to dissolved inorganic carbon (DIC) $\ldots \ldots \ldots \ldots \ldots \ldots \ldots 32$

13. The relationship of dissolved oxygen to $8^{37} \mathrm{Cl}$ of TCE $\ldots \ldots \ldots \ldots \ldots \ldots \ldots \ldots \ldots \ldots$

14. The relationship of normalized $8^{37} \mathrm{Cl}$ of TCE to normalized TCE concentrations ......... 34

15. The relationship of $8^{37} \mathrm{Cl}$ of TCE to $8^{37} \mathrm{Cl}$ of dissolved inorganic chloride (DIC) ......... 35

16. Comparison of redox sensitive parameters along the groundwater flowpath for the Northwest Plume $\ldots \ldots \ldots \ldots \ldots \ldots \ldots \ldots \ldots \ldots \ldots \ldots \ldots \ldots \ldots \ldots \ldots \ldots \ldots \ldots$

17. Comparison of redox sensitive parameters along the groundwater flowpath

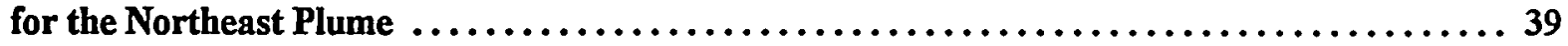

18. Plan view representation of sulfate levels within the RGA $\ldots \ldots \ldots \ldots \ldots \ldots \ldots \ldots \ldots \ldots .40$

19. Plan view representation of nitrate levels within the $R G A \ldots \ldots \ldots \ldots \ldots \ldots \ldots \ldots \ldots$

20. The relationship of argon to nitrogen $\ldots \ldots \ldots \ldots \ldots \ldots \ldots \ldots \ldots \ldots \ldots \ldots \ldots \ldots \ldots . \ldots 44$

21. Potential-pH diagram for iron in the RGA $\ldots \ldots \ldots \ldots \ldots \ldots \ldots \ldots \ldots \ldots \ldots \ldots \ldots \ldots$ 


\section{LIST OF FIGURES AND TABLES (Cont.)}

Eigure Number

Page

22. Plan view representation of chloride levels within the RGA

46

23. The relationship of chloride to TCE $\ldots \ldots \ldots \ldots \ldots \ldots \ldots \ldots \ldots \ldots \ldots \ldots \ldots \ldots \ldots \ldots$

24. Potential-pH stability diagram for ${ }^{99} \mathrm{Tc} \ldots \ldots \ldots \ldots \ldots \ldots \ldots \ldots \ldots \ldots \ldots \ldots \ldots \ldots$

Table Number $\quad$ Page

1. Electron acceptor reactions $\ldots \ldots \ldots \ldots \ldots \ldots \ldots \ldots \ldots \ldots \ldots \ldots \ldots \ldots \ldots \ldots \ldots \ldots \ldots$

2. Screening criteria for NA assessment for chlorinated solvents $\ldots \ldots \ldots \ldots \ldots \ldots \ldots \ldots \ldots$

3. Potential for anaerobic bioremediation $\ldots \ldots \ldots \ldots \ldots \ldots \ldots \ldots \ldots \ldots \ldots \ldots \ldots \ldots \ldots \ldots$

4. Summary of monitoring well information $\ldots \ldots \ldots \ldots \ldots \ldots \ldots \ldots \ldots \ldots \ldots \ldots \ldots \ldots \ldots$

5. Parameters and reporting limits for the NA study $\ldots \ldots \ldots \ldots \ldots \ldots \ldots \ldots \ldots \ldots \ldots \ldots 22$

6. Comparison of site specific geochemical parameters against a biodegradation screening protocol developed by Wiedemeier et al. (1996) $\ldots \ldots \ldots \ldots \ldots \ldots \ldots \ldots \ldots \ldots \ldots \ldots \ldots \ldots$

7. Concentration of redox sensitive parameters in the Northwest Plume $\ldots \ldots \ldots \ldots \ldots \ldots \ldots$

8. Concentration of redox sensitive parameters in the Northeast Plume $\ldots \ldots \ldots \ldots \ldots \ldots \ldots$

9. Comparison of flux rates in the Northwest Plume $\ldots \ldots \ldots \ldots \ldots \ldots \ldots \ldots \ldots \ldots \ldots \ldots$ 


\section{ACRONYMS}

$\begin{array}{ll}\text { ANL } & \text { Argonne National Laboratory } \\ \text { ASTM } & \text { American Society of Testing and Materials } \\ \text { bgs } & \text { below ground surface } \\ \text { BTEX } & \text { benzene, toluene, ethylbenzene, and xylene } \\ \text { CDM } & \text { Camp Dresser \& McKee } \\ \text { CERCLA } & \text { Comprehensive Environmental Response, Compensation, and Liability Act } \\ \text { cis-1,2-DCE } & \text { cis-1,2-dichloroethene } \\ \text { CO } & \text { carbon dioxide } \\ \text { DCE } & \text { dichloroethylene } \\ \text { DIC } & \text { dissolved inorganic carbon } \\ \text { DNAPL } & \text { dense nonaqueous phase liquid } \\ \text { D.O. } & \text { dissolved oxygen } \\ \text { DOE } & \text { U.S. Department of Energy } \\ \text { EPA } & \text { U.S. Environmental Protection Agency } \\ \text { FFA } & \text { Federal Facilities Agreement } \\ \text { f }_{\text {o }} & \text { fraction of organic carbon } \\ \text { H2S } & \text { hydrogen sulfide } \\ \text { HSWA } & \text { Hazardous Solid Waste Authority } \\ \text { HU } & \text { hydrogeologic unit } \\ \text { HWMP } & \text { Hazardous Waste Management Permit } \\ \text { K } & \text { partitioning coefficient } \\ \text { KDEP } & \text { Kentucky Department for Environmental Protection } \\ \text { LMES } & \text { Lockheed Martin Energy Systems, Inc. } \\ \text { LMUS } & \text { Lockheed Martin Utility Services, Inc } \\ \text { MCL } & \text { maximum contaminant level } \\ \text { MTBE } & \text { methyl tertiary-butyl ether } \\ \text { NA } & \text { Natural Attenuation } \\ \text { NCP } & \text { National Oil and Hazardous Substances Contingency Plan } \\ \text { NPL } & \text { National Priority List } \\ \text { PDB } & \text { Pee Dee Belemnite Standard } \\ \text { PGDP } & \text { Paducah Gaseous Diffusion Plant } \\ \text { QC } & \text { quality control } \\ \text { RCRA } & \text { Resource Conservation and Recovery Act } \\ \text { RGA } & \text { regional gravel aquifer } \\ \text { SMOC } & \text { Standard Mean Ocean Chloride } \\ \text { SMOW } & \text { Standard Mean Ocean Water } \\ \text { SWMU } & \text { Solid Waste Management Unit } \\ \text { 99Tc } & \text { technetium-99 } \\ \text { TCE } & \text { trichloroethylene } \\ \text { UCRS } & \text { upper continental recharge system } \\ \text { VC } & \text { vinyl chloride } \\ \text { VOA } & \text { volatile organic analyte } \\ \text { VOC } & \text { volatile organic compound } \\ & \end{array}$




\section{EXECUTIVE SUMMARY}

This document represents the final report on field sampling activities for evaluation of Natural Attenuation Processes (NA) in the Northwest and Northeast Plumes at the Paducah Gaseous Diffusion Plant (PGDP). Although NA processes are active and plume attenuation is occurring, the rate is insufficient to utilize as a viable remedial measure for either dissolved phase plume. Data generated as part of this report, as well as previous site data, indicate the dominant Natural Attenuation (NA) processes for the chlorinated solvents in the regional gravel aquifer (RGA) are advection, dispersion, dilution, and biodegradation. Technetium-99 (9S Tc) is not significantly sorbed, diffused, or precipitated onto the aquifer matrix of the RGA.

The groundwater characteristics for both plumes are: $\mathrm{pH} 5.7-6.3$, Eh +120 to $+460 \mathrm{mV}$, dissolved oxygen (D.0.) 1.0 - $7.9 \mathrm{mg} / \mathrm{L}$, bicarbonate $102-223 \mathrm{mg} / \mathrm{L}$, chloride $20-90 \mathrm{mg} / \mathrm{L}$, sulfate $8.8-30 \mathrm{mg} / \mathrm{L}$, nitrate $<0.7-50$ $\mathrm{mg} / \mathrm{L}$, total iron $<0.3-3.2 \mathrm{mg} / \mathrm{L}$, hydrogen sulfide $<0.01-0.04 \mathrm{mg} / \mathrm{L}$, ammonia $<0.1 \mathrm{mg} / \mathrm{L}$. Eh and D. O. data indicate an oxic and aerobic environment. Electron redox couples of nitrate, sulfate, and iron suggest a lack of anaerobic biological activity based on the spatial distribution of the terminal electron acceptors. The relationship of declining $\mathrm{D}$. $\mathrm{O}$. concentrations with increased bicarbonate levels is consistent with aerobic respiration by microorganisms within the aquifer. However, the geochemical data for the water samples do not indicate an energy source, I. e. organic carbon, toluene, methane, ammonia etc., sufficient for biological processes to occur.

Carbon isotope ratios of trichloroethylene (TCE) range from -30.4 to -26.7 per mil Pee Dee Belemnite (PDB). Chlorine isotope ratios of TCE range from -1.0 to +2.0 per mil Standard Mean Ocean Chloride (SMOC). Oxygen isotope ratios of water range from -5.8 to -4.9 per mil (Standard Mean Ocean Water SMOW). The isotopic data indicate minor biological degradation of TCE, little or no difference in source composition of TCE in the two plumes, and no difference in water source for the two plumes. These conclusions are consistent with the relatively low cis-1,2-dichloroethene (cis-1,2-DCE)/TCE concentration ratios in the plumes $(<0.00008$ to 0.022 ) and the generally oxidizing conditions of the aquifer. Increased isotopic chloride $\left(\delta^{37} \mathrm{Cl}\right)$ levels in relation to decreased TCE concentrations is suggestive of slow degradation of TCE. Anaerobic degradation of TCE is postulated to occur in organic-rich micro-environments within a generally aerobic aquifer at PGDP.

A TCE half-life in excess of 25 years was calculated for a region between the U. S. Department of Energy (DOE) property boundary and northern extraction well field in the Northwest Plume. Based on current TCE concentrations and reliance on NA processes coupled with the existing containment system, TCE levels will remain above the maximum contaminant level (MCL) of $0.005 \mathrm{mg} / \mathrm{L}$ for over 100 years. TCE levels between the source region, $\mathrm{C}-400$, and the southern extraction well field in the Northwest Plume will remain above MCLs until the dense, non-aqueous phase liquid (DNAPL) source area is removed, isolated, or depleted.

TCE and cis-1,2-DCE levels in the plumes ranged from $<0.001$ to $16 \mathrm{mg} / \mathrm{L}$ and $<0.001$ to $0.058 \mathrm{mg} / \mathrm{L}$, respectively. Vinyl chloride, ethylene, ethane, and chloroethene were not detected in any samples from this study. ${ }^{99} \mathrm{Tc}$ levels ranged from $<25$ to $4178 \mathrm{pCi} / \mathrm{L}$. Aerobic aquifer conditions suggest the dominant form of ${ }^{99} \mathrm{Tc}$ is pertechtenate which behaves as a conservative anion. Thus, the only mechanism identified for reduction of ${ }^{99} \mathrm{Tc}$ within the plumes is advection, dispersion, and dilution. 


\section{INTRODUCTION}

The Paducah Gaseous Diffusion Plant (PGDP), located within the Jackson Purchase region of western Kentucky, is an active uranium enrichment facility owned by the U.S. Department of Energy (DOE) (Figure 1). Effective July 1, 1993, DOE leased the PGDP production operations facilities to the United States Enrichment Corporation, which in turn contracted with Lockheed Martin Utility Services, Inc. (LMUS) to provide operations and maintenance services. Lockheed Martin Energy Systems, Inc. (LMES) manages the Environmental Management and Enrichment Facility activities at PGDP for DOE.

PGDP has operated continuously since 1952 and produces enriched uranium for commercial nuclear reactors. Plant operations have resulted in waste streams common to many large industrial facilities, namely chlorinated solvents. A common degreaser used at the PGDP site, since its initial operation from 1952 through 1993, was trichloroethylene (TCE). The largest quantities of TCE were used at the C-400 facility located near the center of the plant. During various plant upgrades piping and equipment from the enrichment facilities, which was contaminated with various radionuclides, was degreased and became contaminated with technetium- 99 $\left.{ }^{99} \mathrm{Tc}\right)$. The ${ }^{99} \mathrm{Tc}$ is a byproduct of nuclear fission and reactor tails processed in the $1950 \mathrm{~s}$ and 1970 s by PGDP. ${ }^{99} \mathrm{Tc}$ tends to accumulate near the front end of the enrichment process.

In 1988, TCE was detected offsite in residential wells exceeding the U. S. Environmental Protection Agency (EPA) maximum contaminant level (MCL) of $0.005 \mathrm{mg} / \mathrm{L}$. Subsequent investigations led to the identification of two large groundwater plumes extending offsite (CH2M Hill, 1990; CH2M Hill, 1991; Clausen et al., 1993; Clausen et al., 1995a; DOE, 1996). The Northwest Plume has a length of approximately 3.1 miles and the Northeast Plume is 2.7 miles long. The contaminants of concern in the Northwest Plume are TCE and ${ }^{99} \mathrm{Tc}$. Although the Northeast Plume contains both TCE and ${ }^{99} \mathrm{Tc}$, the latter is only present within the DOE plant security fence. Combined, the two groundwater plumes have contaminated approximately 6 billion gallons of water. Additional details on the distribution of contaminants within each plume can be found in Clausen et al. (1993); Clausen et al. (1995a); DOE (1996); and Laase and Clausen (1997).

Over the past several years, a remedial alternative gaining increasing acceptance for compounds dissolved in groundwater is Natural Attenuation (NA). NA in conjunction with source treatment or containment can be a remedial alternative for many sites (EPA, 1997). Data collected from both plumes suggested attenuating mechanisms are in operation. Currently, two hydraulic containment systems have been installed at the DOE property boundary for the Northeast and Northwest Plumes. Additionally, several source areas are being evaluated for treatment. Therefore, an evaluation of NA at this time seems appropriate and consistent with the overall groundwater strategy at PGDP. In general, the level of site characterization necessary to support NA is greater than that needed to support active remediation which then led to the initiation of this study.

Currently, there are no regulatory approved regulations or guidelines for implementating NA as a remedial option. The current practice is to follow guidelines set forth in an Air Force developed protocols for hydrocarbons and chlorinated solvents (Wiedemeier et al., 1995 and 1996). EPA Region IV has developed a draft approach manual, developed largely from guidance in the Wiedemeier et al. (1995 and 1996) reports. EPA is developing a NA directive for petroleum and hazardous sites to be released in the near future (Tulis, 1997). Additionally, American Society of Testing and Materials (ASTM) is developing guidance for NA assessments. In the interim, the default approach used was the reliance on the 


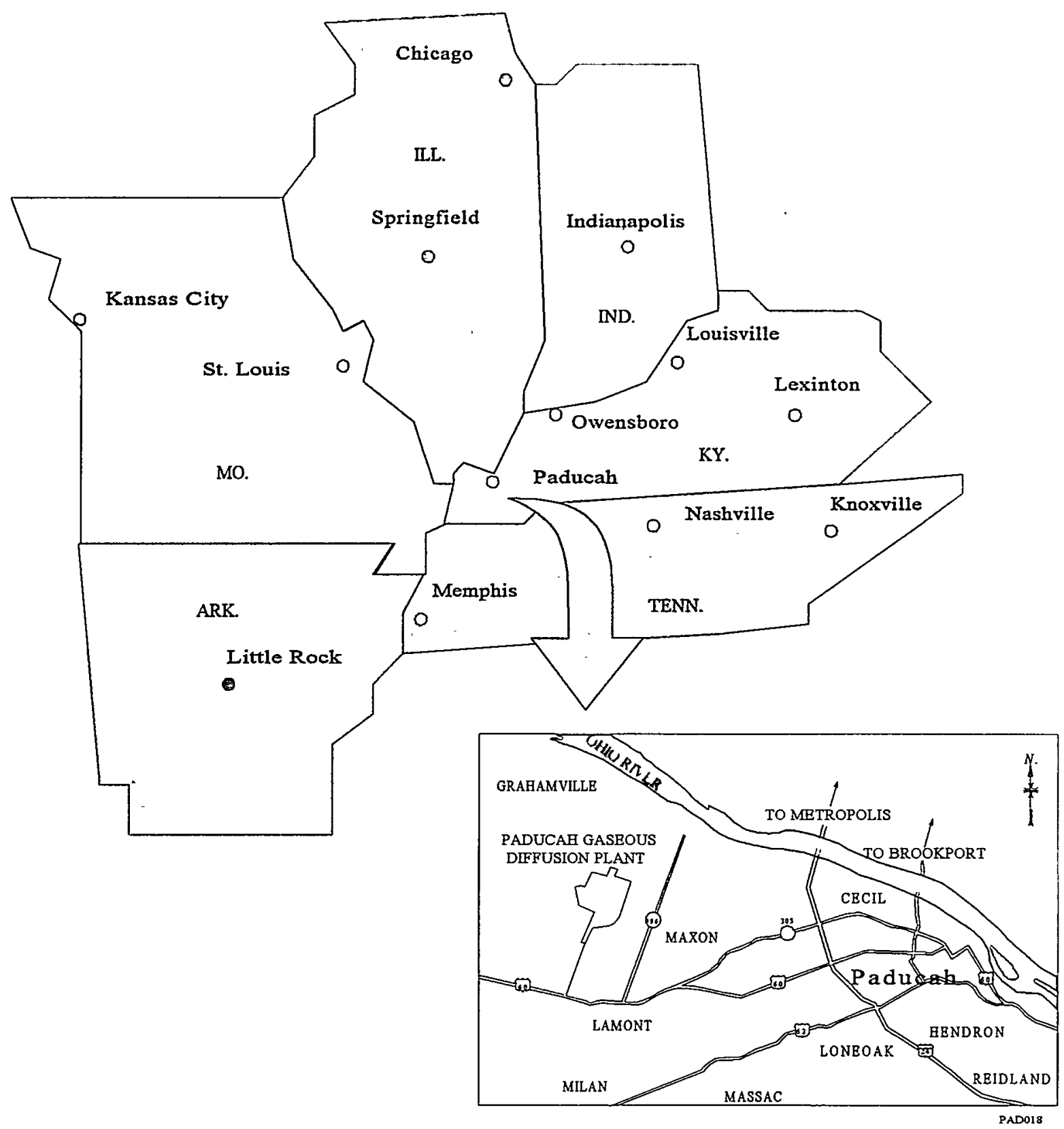


Weidemeier et al. (1996) approach for chlorinated solvents. In the case of radionuclides, ${ }^{99} \mathrm{Tc}$ in particular, no existing guidance is available.

\subsection{PROJECT SCOPE}

The scope of the project consisted of sampling 15 monitoring wells located in the Northwest and Northeast Plumes and background locations for an evaluation of geochemical parameters (Figure 2). The geometry of the plumes is based on the monitoring of over 300 wells. This information was used to assess the effectiveness of Natural Attenuation (NA) processes for remediation of the Northwest and Northeast contaminant plumes.

\subsection{PROJECT OBJECTIVES}

The three major objectives for this NA study included collection of: 1) geochemical data to further assess the extent and concentrations of contaminants within the Northwest and Northeast Plumes, 2) geochemical data to provide evidence of NA and assess natural biodegradation, and 3) chemical and physical data for input into fate-and-transport modeling. Previous work focused on objectives one and three have largely been completed through previous investigations (CH2M Hill, 1990; CH2M Hill, 1992; Clausen et al., 1992; Clausen et al., 1993; Clausen et al., 1995a; DOE, 1996). Thus, the objective of this study was to focus on the second objective.

One of the methods utilized to answer whether NA is a significant process was through the analysis of stable isotopes. Aggarwal et al. (1997) utilized stable isotopes of carbon and oxygen to monitor pathways and rate of biodegradation. The objectives of using stable isotope ratios (of carbon and chlorine in TCE; dissolved inorganic carbon (DIC); inorganic chlorine; and oxygen in water) are to determine: (1) the possible extent of natural TCE attenuation; (2) whether the two plumes could have different TCE sources; and (3) whether the contaminated plumes could have different water sources, as evidenced by variations in oxygen isotope ratios of water. Based on the outcome of this study, recommendations are made on the practicality of pursuing a NA approach for the final disposition of the Northeast and Northwest Plumes and whether biological microcosm studies are warranted.

\subsection{REGULATORY OVERVIEW}

The Environmental Program at PGDP is driven by several laws and regulations. In general, these laws include the Resource Conservation and Recovery Act (RCRA), Comprehensive Environmental Response, Compensation, and Liability Act (CERCLA), Clean Water Act, Toxic Substances Control Act, and applicable Kentucky Department for Environmental Protection (KDEP) statutes. Although all of these regulations impact the Environmental Program at PGDP, CERCLA and RCRA and applicable state laws are considered to be the primary laws and regulations driving the investigation and remediation activities at the PGDP site.

RCRA and corresponding state law requirements for PGDP are contained in two separate but related permits: Hazardous Waste Management Permit (HWMP), issued and administrated by KDEP, and the Hazardous Solid Waste Authority (HSWA) Permit, issued and administrated by EPA. The HWMP and HSWA permits were issued on July 19, 1991, and July 16, 1991, respectively, and constitute the RCRA 
Figure 2. The location of sample collection points within the Northeast and Northwest Plumes

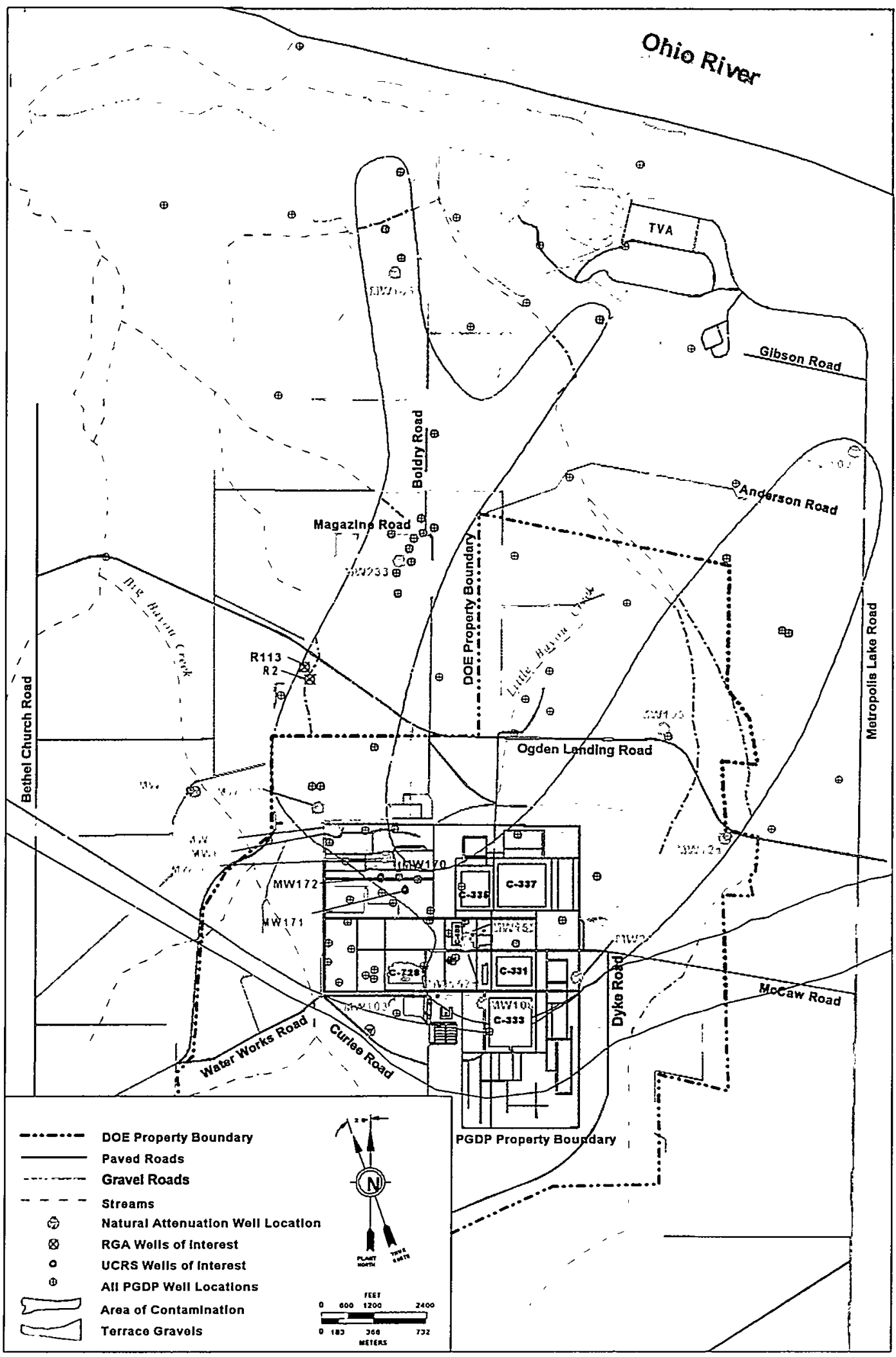

Natural Attenuation Sampling Points

NATATT 
permits for PGDP. These permits include corrective action requirements for Solid Waste Management Units (SWMUs).

EPA scored PGDP using the Hazardous Ranking System to determine the site's eligibility for inclusion on the National Priority List (NPL) as promulgated under Section 105 of CERCLA and 40 Code of Federal Register 300 National Oil and Hazardous Substances Contingency Plan (NCP). PGDP was listed on the NPL on May 31, 1994. Section 120 of CERCLA requires federal facilities listed on the NPL to enter into an Federal Facilities Agreement (FFA) with the EPA. A FFA for PGDP is currently being negotiated between DOE, EPA, and KDEP.

The EPA, DOE, and the KDEP are negotiating a FFA in conjunction with final listing of PGDP on the NPL of CERCLA sites. The FFA will ensure compliance pursuant to CERCLA, RCRA, and the NCP. A common goal of FFA participants is to ensure past releases from operations and waste management activities at PGDP are investigated and appropriate remedial action is taken for protection of human health and the environment.

The primary purpose of the FFA is to establish a procedural framework and schedule to investigate and remediate contaminant releases at sites posing a threat to human health, welfare, and the environment. The FFA for PGDP will incorporate the site investigation process as initiated in accordance with the CERCLA Administrative Order by Consent and requirements stated in the EPA HSWA and Kentucky HSWP.

\subsection{SITE GEOLOGY}

The stratigraphy at PGDP consists of Cretaceous, Tertiary, and Quaternary sediments which uncomfortably overlie Paleozoic bedrock. Depth to bedrock is approximately $300 \mathrm{ft}$ below ground surface (bgs). The sediments (Pleistocene age) are divided into two main facies: lower continental deposits and upper continental deposits (Figure 3). The lower continental deposits consist of chert gravel in a matrix of poorly sorted sand and silt. The depth of the lower continental deposits is approximately 60 to $100 \mathrm{ft}$ bgs. Some gravels appear to have a limonite or manganese oxide coating (Clausen et al., 1995a). Chemical analysis of this material has not been performed to date.

Overlying the lower continental deposits are the upper continental deposits which consist of clayey silt interspersed with discrete lenses of sand and gravel. Beneath these two units is the McNairy Formation which can vary from clay to sand in composition. Detailed discussions of the site geology can be found in Clausen et al. (1992).

\subsection{SITE HYDROGEOLOGY}

Douthitt and Phillips (1991) developed five hydrogeologic units (HUs) to explain groundwater flow at PGDP. Additionally, the HUs have been grouped together based on their hydrologic similarities. HU1 through HU3 are collectively referred to as the upper continental recharge system (UCRS). HU4 and HU5 are known as the regional gravel aquifer [RGA] (Figure 4). The RGA also includes the upper portion of the McNairy Formation in hydraulic connection with the RGA. In descending order, the HUs are: 


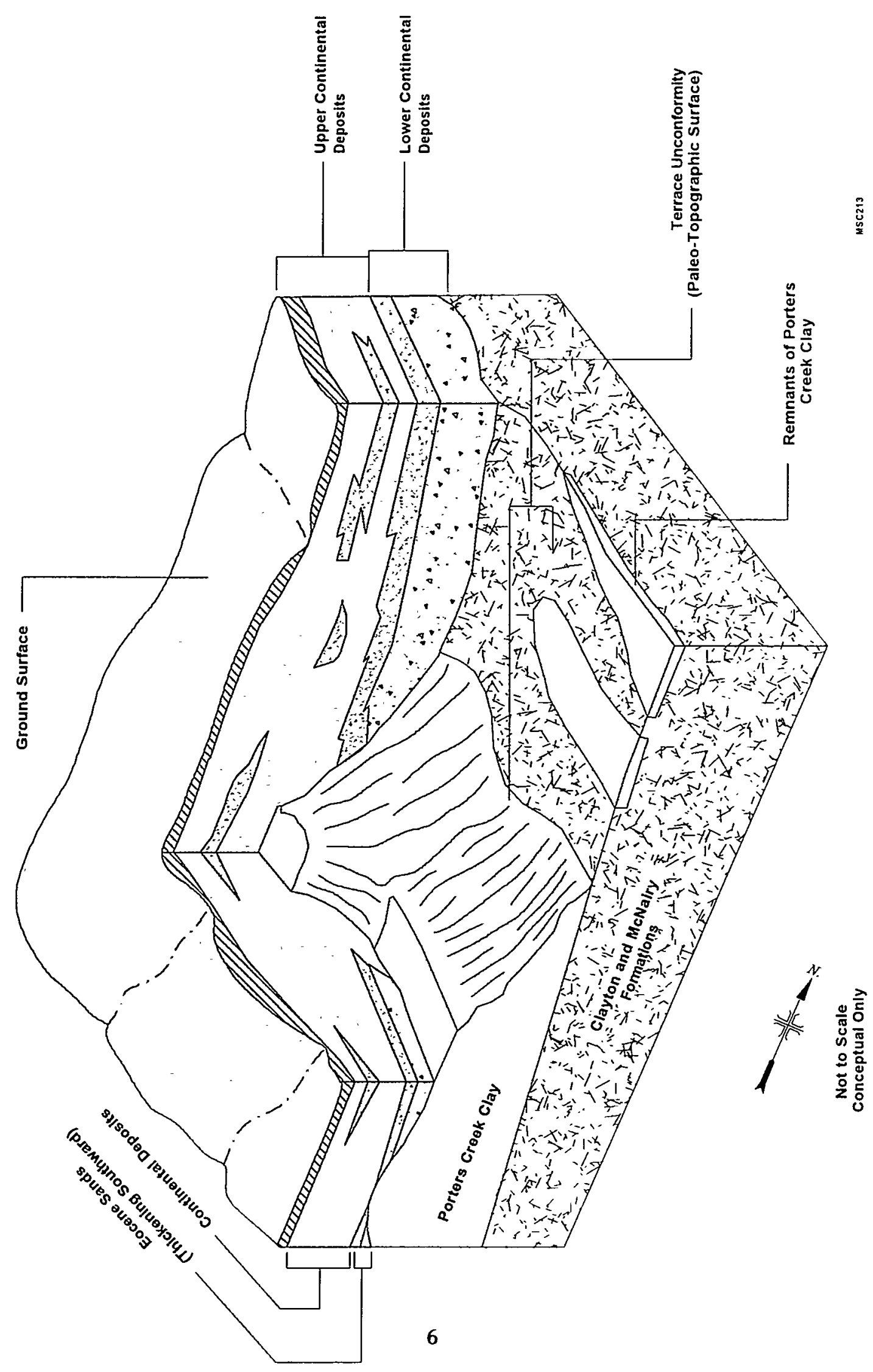



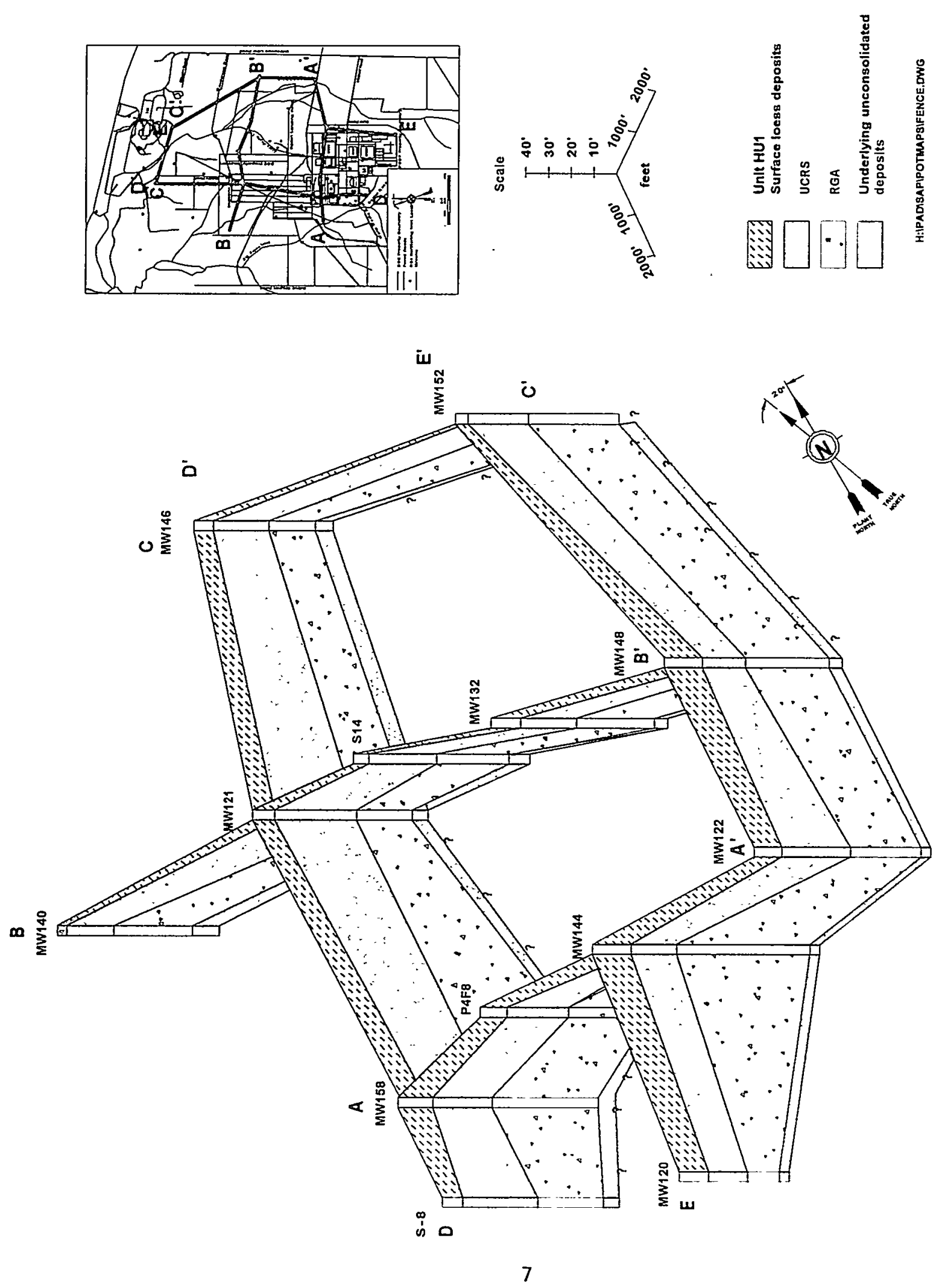


\section{Upper Continental Deposits}

- HU 1 (UCRS): loess which covers the entire site.

- HU 2 (UCRS): discontinuous, but correlatable, sand and gravel lenses in a clayey silt matrix.

- HU 3 (UCRS): lower permeability clay layer that acts as a semi-confining layer for the RGA. The lithologic composition of this unit varies from clay to sand but is predominantly clay or silt.

- HU 4 (RGA): predominantly continuous sand unit with a clayey silt matrix which directly overlies the RGA. This unit is in hydraulic connection with HUS and is included as part of the RGA.

\section{Lower Continental Deposits}

- HU 5 (RGA): gravel, sand and silt. This is the primary pathway for groundwater transport of contaminant away from SWMU 2 and is the uppermost aquifer in the area of PGDP.

The hydraulic conductivity of sands comprising HU 2 and HU 4 are typically two orders of magnitude or larger than clays and silts which make up HUl and HU 3 (Clausen et al., 1992). The HUs present a vertical profile of alternating hydraulic conductivities, and within each HU lateral heterogeneity also exists. The sand lenses within the UCRS, although laterally extensive, are not always continuous beneath PGDP. On the larger scale, sand lenses within the UCRS decrease in frequency towards the Ohio River. In contrast, the hydraulic conductivity of HU 5 is 3 to 5 orders of magnitude higher than

HU 2 or HU 4. Groundwater flow through the UCRS to the RGA is primarily vertical due to extreme differences in the hydraulic conductivity of these two units (Clausen et al., 1992).

The Ohio River is base level for the RGA, therefore groundwater flow is generally from south to north. However, flow directions in the RGA are highly variable and dependent on Ohio River stage and precipitation (Moore and Clausen, 1997). The RGA behaves as a semi-confined aquifer based on pumping tests (Terran, 1990; and 1992; CH2M Hill, 1992; and Phillips, 1996). The potentiometric map of the RGA during the sampling period is presented in Figure 5. The hydraulic conductivity of the RGA based on aquifer and slug tests ranges from 0.62 to $7928 \mathrm{ft} /$ day (Terran 1990 and 1992; CH2M Hill, 1992; and Phillips, 1996) and appears to be scale dependent. The average hydraulic gradient for the RGA ranges from 0.0002 to 0.001 and is spatially specific (Moore and Clausen, 1997). Effective porosity values of 0.2 to 0.3 are assumed to be representative of the RGA based on a measurement of 0.25 by McConnell (1992) and is consistent with the work by Freeze and Cherry (1979) for sand and gravel aquifers. The average thickness of the RGA is $30 \mathrm{ft}$ which yields a flow velocity of 0.15 to $15.9 \mathrm{ft} /$ day with a mean of $1.3 \mathrm{ft}$ /day (Clausen et al., 1995a). However, the thickness of the RGA can vary from 5 to $50 \mathrm{ft}$.

\subsection{SITE GEOCHEMISTRY}

The major ion chemistry of RGA water at PGDP falls into the bicarbonate classification with a pH in the 5.4 to 7.7 range with a mean value of 6.3 (Clausen et al., 1992). Fryar (1997) corrected Eh measurements (CH2M Hill, 1990 and 1992) for temperature which yielded values in the +113 to $+680 \mathrm{mv}$ range which is indicative of toxic conditions. 
Figure 5. Potentiometric map for the RGA during May 1997

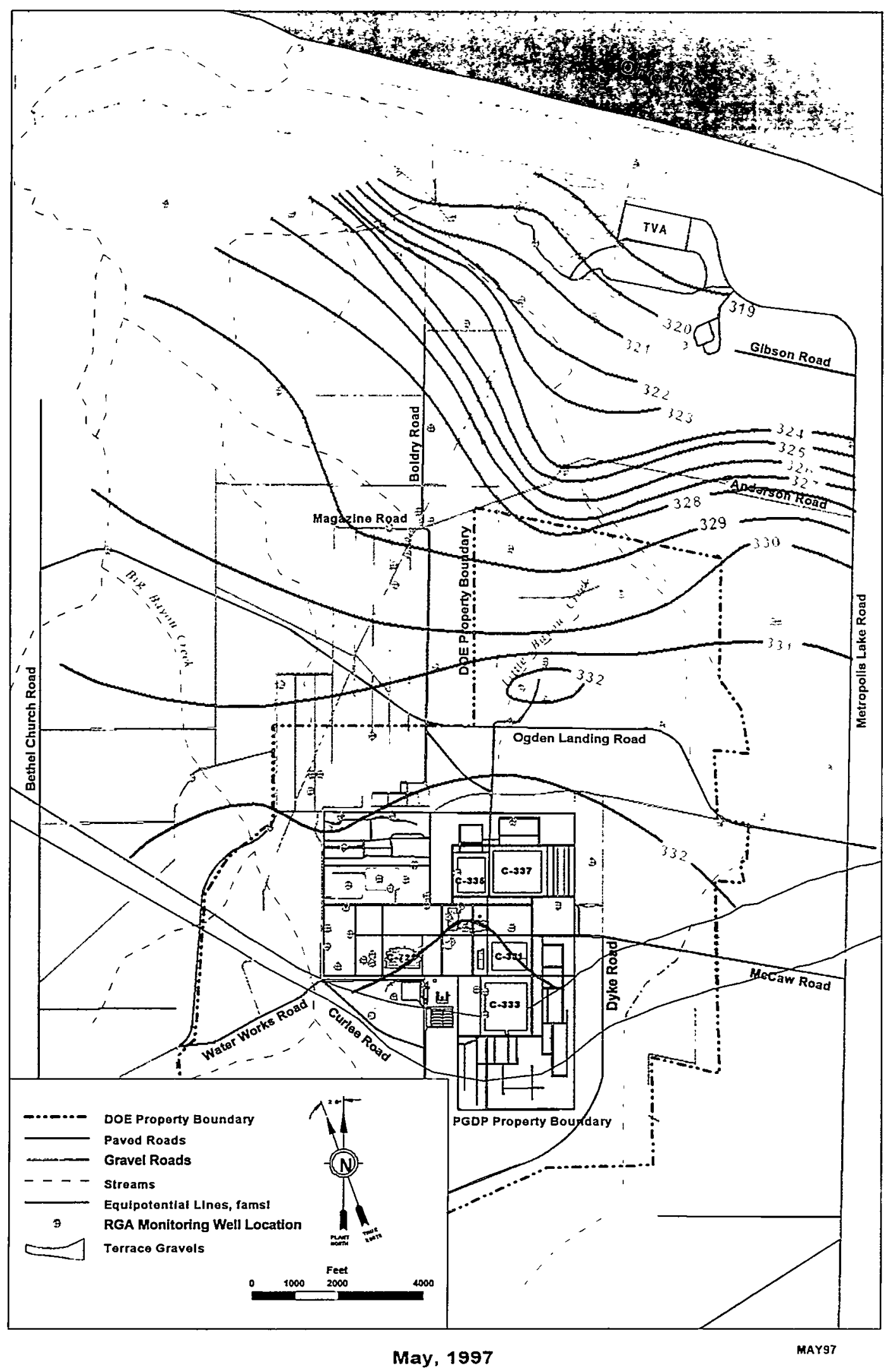


Routine sampling data indicates dissolved oxygen (D.O.) values in excess of $0.5 \mathrm{mg} / \mathrm{L}$ as measured with a Hydrolab ${ }^{\mathrm{MM}}$ instrument using a flow through cell. Typical values in the RGA range from 2 to $8 \mathrm{mg} / \mathrm{L}$ indicating an aerobic environment.

The contaminants of concern, as discussed in Section 1 are TCE and ${ }^{99} \mathrm{Tc}$. In general, TCE concentrations range near the detection limit, $0.001 \mathrm{mg} / \mathrm{L}$, at the distal portions of the plumes to near the solubility limit of 1,100 $\mathrm{mg} / \mathrm{L}$ at the source (Clausen et al., 1995a and DOE, 1996). The source of both TCE plumes appears to be the C-400 building located near the center of the DOE facility (Laase and Clausen, 1997). A co-contaminant in both plumes is ${ }^{99} \mathrm{Tc}$, a radionuclide, with a half-life of 210,000 years. ${ }^{99} \mathrm{Tc}$ levels range from the detection limit, 25 $\mathrm{pCi} / \mathrm{L}$, at the periphery of the plumes to $40,000 \mathrm{pCi} / \mathrm{L}$ near the source for the Northwest Plume (Clausen et al., 1995a and DOE, 1996). ${ }^{99} \mathrm{Tc}$ in the Northeast Plume is limited to within the DOE fence boundary and a hypothesis is presented in Laase and Clausen (1997). Briefly, Laase and Clausen (1997) speculated that the source of the Northwest Plume is dense, nonaqueous phase liquid (DNAPL), which originated from the south side of the C-400 building, and now resides in the RGA. The ${ }^{99} \mathrm{Tc}$ is from a decontamination water collected in a tank located on the north side of $\mathrm{C}-400$ which may have leaked or from a drainage ditch which received effluent water from C-400. The Northeast Plume originates from residual DNAPL within the upper UCRS on the south side of C-400. ${ }^{99} \mathrm{Tc}$ is not present at elevated levels within the UCRS on the south side of C-400. A groundwater divide exists beneath the building due to leaking utility lines which prevents ${ }^{99} \mathrm{Tc}$ from migrating from the north end of $\mathrm{C}-400$ to the south end.

The likely form of ${ }^{99} \mathrm{Tc}$ at PGDP is as the pertechnetate anion based on a literature review, D. O. measurements, and $\mathrm{Eh} / \mathrm{pH}$ measurements from the site (Clausen et al., 1995b). The shortcomings of Eh measurements should be noted. The authors acknowledge the problem of internal disequilibrium as discussed by Stumm and Morgan (1981), Lindberg and Runnels (1984), and Thorstenson (1984). Secondly, the electrodes respond to few of the geochemically significant redox couples (Lovley et al., 1994). A plot of RGA potential-pH data with ${ }^{99} \mathrm{Tc}$, corrected for temperature, indicates most sample results fall in the $\mathrm{TcO}(\mathrm{OH})_{2}$ and $\mathrm{TcO}_{4}{ }^{-}$fields (Clausen et al., 1995b). The breadth of the vertical variations in Eh is indicative of the lack of redox equilibrium. In any case, the redox conditions in general support the work of $\mathrm{Gu}$ et al. (1994) and $\mathrm{Gu}$ and Dowlen (1996) which found ${ }^{99} \mathrm{Tc}$ is not transported as a colloidal particle, sorbed or complexed with natural organic matter in groundwater, or sorbed onto the aquifer matrix. Furthermore, the presence of ${ }^{99} \mathrm{Tc}$ off-site to a distance of 3.1 miles from the source is suggestive of a non-reactive solute. Thus, all of the data collected to date is suggestive that $\mathrm{TcO}_{4}^{-}$is the form of ${ }^{99} \mathrm{Tc}$ present at the PGDP site. Given the nature of $\mathrm{Tc} \oint$ and the work of $\mathrm{Gu}$ and Dowlen (1996) ${ }^{99} \mathrm{Tc}$ is not expected to be retarded to any significant degree by the sediments at PGDP. Gu and Dowlen (1996) show ${ }^{99} \mathrm{Tc}$ behaves essentially as an unreactive tracer at PGDP.

\section{GENERAL OVERVIEW OF NA}

EPA defines NA as the biodegradation, dispersion, dilution, sorption, volatilization, and/or chemical and biochemical stabilization of contaminants to effectively reduce contaminant toxicity, mobility, or volume to levels protective of human health and the ecosystem (NCP, 1996). The NA approach is not a no-action alternative but rather consists of a geochemical and biological evaluation coupled with modeling and long term monitoring. Additionally, regulatory approval for NA, in most cases, will require some form of source isolation or removal and a contingency "backup" remedy in the event the "selected" remedy fails to perform as anticipated. NA is recommended only when active restoration is not practicable, cost effective, or warranted because of site specific conditions (NCP, 1996). Additionally, NA should not be considered a default or presumptive remedy at any contaminated site (Fields, 1997). The NA approach must reduce the concentration of contaminants in 
groundwater to remediation goal levels in a reasonable time. Reasonable time is defined by the intended use of the groundwater resource but should be comparable to an engineered remedial approach (EPA, 1997).

\subsection{PROTOCOL FOR NA EVALUATION}

A typical NA project to be presented to the regulatory agencies for approval would consist of the following activities; 1) sampling of wells for contaminants, geochemical, biological, and biogeochemical indicators, 2) microcosm studies for organic compounds and absorption/desorption mechanistic studies for metals to determine kinetic rates, 3) installation of monitoring wells along the axis and cross-gradient to the plume axis for mass flux calculations, 4) fate-and-transport modeling, 5) final NA report, and 6) long term monitoring. Key to an NA approval is documentation of a thorough review of site specific data and presentation of a site conceptual model. The final NA report should include an exposure pathway and risk analysis along with mechanistic studies if NA is to be applied for metals or radionuclides. Additionally, evaluation of other remedial options in concert with NA must be presented (EPA, 1997).

In general, there are three lines of evidence used to evaluate NA. The primary line of evidence is a declining contaminant mass or concentrations of a given monitoring point. The second line of evidence is the type of NA by measuring geochemical parameters, such as D. O., nitrate, iron, sulfate, ammonia, carbon dioxide, etc. The final line of evidence is from field microcosm studies that demonstrate microbial activity and a rate sufficient for utilization of NA. The focus of this study is on the first two lines of evidence.

\subsection{BIODEGRADATION}

Three major processes whereby chlorinated aliphatic hydrocarbons are transformed/destroyed is through reductive dechlorination (electron acceptor reactions), aerobic cometabolism, and direct oxidation. Electron donor reactions are a possible fourth process, but this mechanism has not been documented for the dechlorination of TCE. Microorganisms capable of aerobic metabolism will predominate over anaerobic forms if sufficient oxygen and an organic substrate is present (EPA, 1996b). However, aerobic metabolism is very efficient resulting in rapid consumption of oxygen in contaminant plumes and subsequent creation of anoxic conditions. Although aerobic degradation rates may be fast, (i.e minutes); the rate of oxygen replenishment by groundwater flow is generally slow, (i.e. years). Thus, in many instances oxygen is limited, making reductive dechlorination the predominant mechanism and most efficient for the destruction of chlorinated solvents under natural conditions.

\subsubsection{Electron Acceptor Reactions}

Electron acceptor reactions or reductive dechlorination are a natural process which have been demonstrated to occur at numerous field sites and in laboratory studies (Bouwer 1984; Freedman \& Gosset, 1989; Vogel and McCarty, 1985). The process occurs by sequential dechlorination of TCE to dichloroethylene (DCE), vinyl chloride (VC), and ethene as illustrated in Figure 6. The ultimate 
Figure 6. Reductive dechlorination pathway of TCE

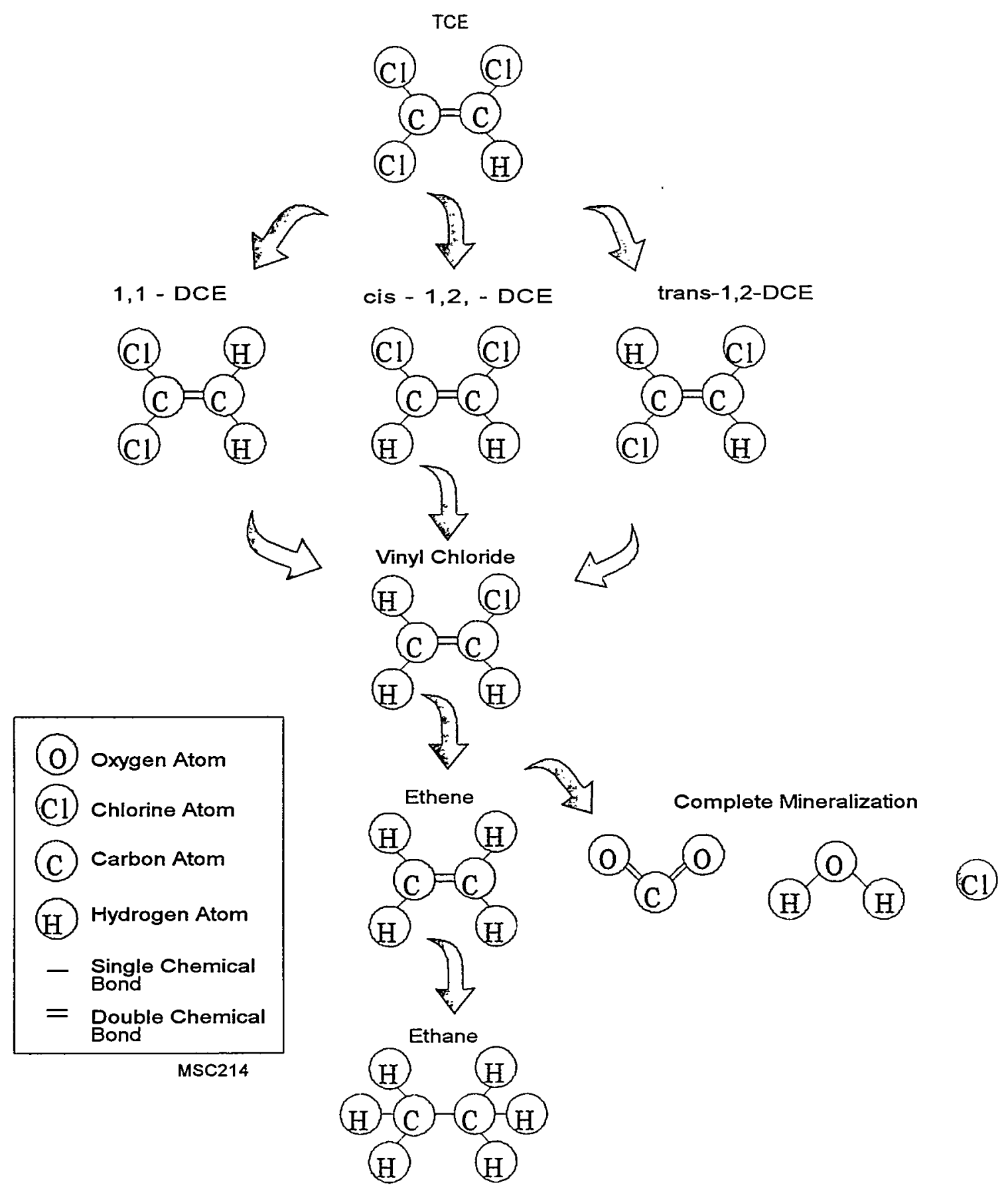


pathways are dependent upon the environmental conditions at a given site but the predominant TCE byproduct is the cis-1,2-dichloroethene (cis-1,2-DCE) isomer. The complete process can proceed along two pathways. The first pathway is complete dechlorination of TCE to ethene under anaerobic conditions. In this process, certain types of reducing conditions will result in transfer of an electron to the chlorinated hydrocarbon.

The electron accepting process has been described in detail by Chapelle et al. (1995) and can consist of a pattern of electron acceptors as exhibited in Figure 7. The pattern of electron acceptor consumption can provide insight into redox processes responsible for reductive dechlorination (Chapelle et al., 1995). Methanogenic and sulfate reducing processes tend to be the most efficient in dechlorination of chlorinated solvents (Table 1). Methanogenesis is identified on the basis of an accumulation of methane (Thorstenson et al., 1979 and Baedecker et al, 1988). Methane in groundwater can originate from two sources; microbial processes or thermogenic origin. The presence of hydrocarbons such as ethane, butane, propane, or hexane with methane is an indicator of petroleum formation (Coleman et al., 1977 and Barker and Fritz, 1981). Microbial processes rarely generate hydrocarbons higher than ethane (Barker and Fritz, 1981). In the case of sulfate reduction, evaluation of sulfate consumption or sulfide production can be useful in identifying the mechanism in operation (Thorstenson et al, 1979 and Jackson and Patterson, 1982). The other two processes, iron and nitrate reduction are the least efficient and can be identified by the consumption of nitrate or accumulation of dissolved iron (Langmuir, 1969; Baedecker and Back, 1979; Bulger et al., 1989; and Chapelle and Lovely, 1992).

Table 1. Electron acceptor reactions

\begin{tabular}{|c|c|c|c|c|}
\hline $\begin{array}{c}\text { Electron } \\
\text { Acceptor }\end{array}$ & $\begin{array}{c}\text { Reaction } \\
\text { Environment }\end{array}$ & $\begin{array}{c}\text { Metabolic } \\
\text { By-Product }\end{array}$ & $\begin{array}{c}\text { Reaction } \\
\text { Efficiency }\end{array}$ & $\begin{array}{c}\text { Mechanistic } \\
\text { Process }\end{array}$ \\
\hline Carbon Dioxide & Anaerobic & Methane & Most Efficient & Methanogenesis \\
\hline Sulfate & Anaerobic & $\mathrm{H}_{2} \mathrm{~S}$ & 1 & Sulfate Reduction \\
\hline Ferric Iron & Anaerobic & Ferrous Iron & 1 & Iron Reduction \\
\hline Nitrate & Anaerobic & $\mathrm{N}_{2}, \mathrm{CO}_{2}$ & $\downarrow$ & Nitrate Reduction \\
\hline Oxygen & Aerobic & $\mathrm{CO}_{2}$ & Least Efficient & Oxidation \\
\hline
\end{tabular}

However, as pointed out by Chapelle et al. (1995) terminal electron acceptor patterns do not always clearly define the redox processes. Dissolution or precipitation of electron acceptors with the geologic media can confuse the identification of the dominant microbiological processes. For example, sulfide is produced by reduction of sulfate which may react with ferrous iron forming a precipitate. Thus, increased sulfide levels may not be evident even when sulfate reduction is occurring. On the other hand, iron reduction results in the production of ferrous iron and reaction with sulfides in the geologic media could result in precipitation of the ferrous iron obscuring the iron reductive process. For this reason, Chapelle et al. (1995) recommends measuring hydrogen levels which are metabolic intermediaries of anaerobic reduction processes. Hydrogen concentrations can be used to pin-point the dominant reductive mechanism (Chapelle and Lovley, 1992). 


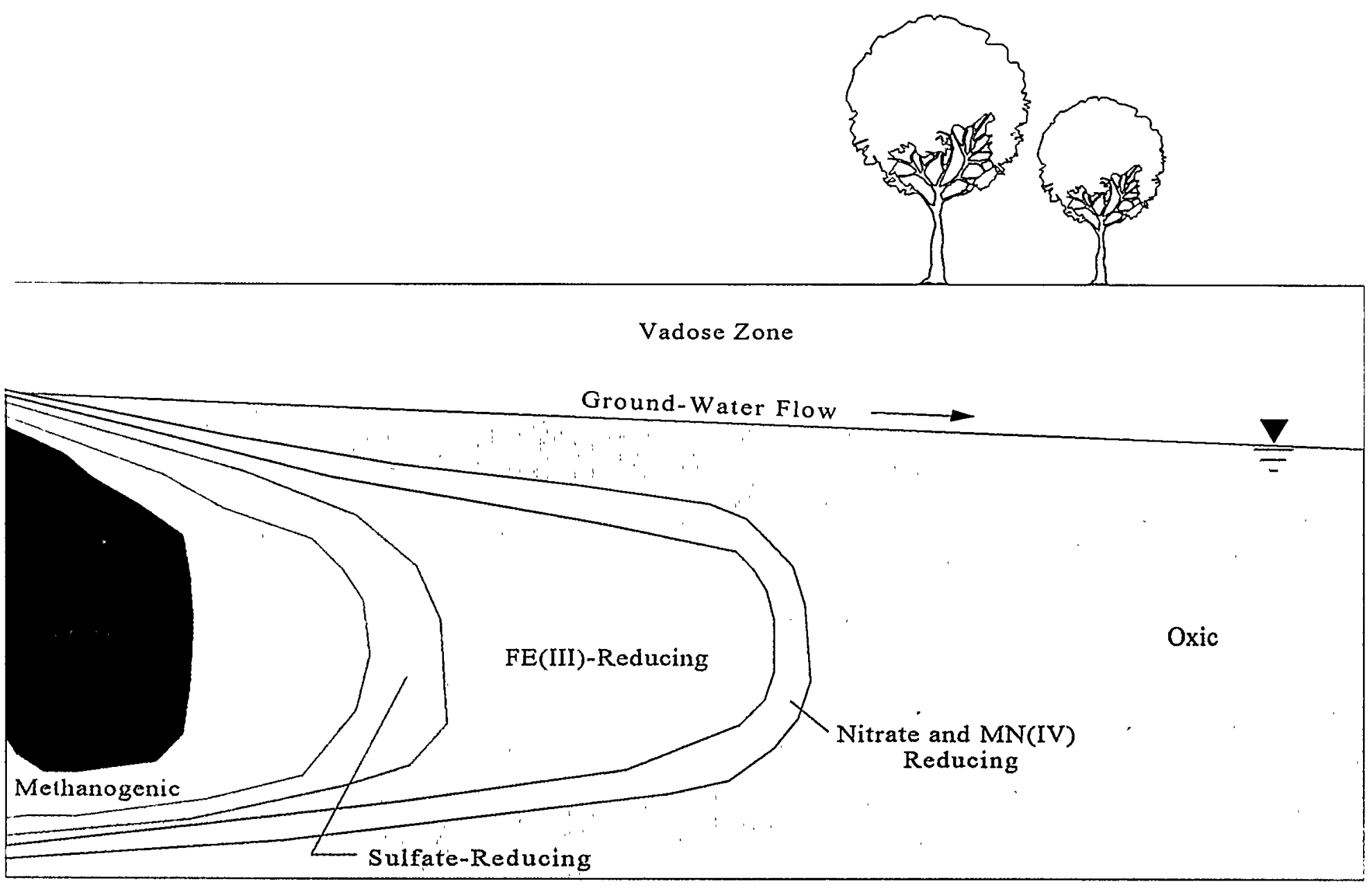


The second electron transfer pathway involves complete dechlorination of TCE to VC under anaerobic conditions, followed by mineralization of VC under aerobic conditions. The dechlorination process results in accumulation of daughter products and increase in chloride ion concentrations. In all cases, a primary substrate is required (natural organic matter or hydrocarbon fuels) which serve as the carbon and energy source for microbial metabolism.

\subsubsection{Electron Donor Reactions}

Electron donor reactions or direct oxidation consist of the chlorinated hydrocarbon acting as the electron donor providing energy and carbon for the microorganism. The theoretical stoichiometry for complete oxidation (mineralization) of TCE to carbon dioxide $\left(\mathrm{CO}_{2}\right)$, water, ethene, and chloride is as follows:

$$
2 \mathrm{C}_{2} \mathrm{HCl}_{3}+9 \mathrm{O}_{2} \rightarrow 4 \mathrm{CO}_{2(\mathrm{~B})}+\mathrm{H}_{2} \mathrm{O}+6 \mathrm{Cl}^{-}
$$

From this stoichiometric equation it is evident for every mole of TCE oxidized three moles of chloride are produced. Since many halogenated aliphatic compounds, such as TCE, are relatively oxidized they have few electrons available for microorganisms to utilize for oxidation. Work by Murray and Richardson (1993) suggests microorganisms are incapable of growth using TCE as the primary substrate under aerobic conditions, although McCarty and Semprini (1994) have reported reduction of VC under aerobic conditions in the laboratory. However, Chapelle (1993) suggests there are no known microorgansims capable of using TCE as a sole electron or carbon source and this may explain the persistence of TCE and similar compounds in aerobic aquifer systems.

\subsubsection{Aerobic Cometabolism}

Another aerobic process is the cometabolism of a chlorinated hydrocarbon. Early work by Pearson and McConnell (1975); Hill et al. (1976); Rittmann (1980); Bouwer and McCarty (1981); Bouwer et al. (1981); Tabak et al. (1981); Bouwer and McCarty (1982); and Wilson et al. (1983) suggested chlorinated aliphatic hydrocarbons, such as TCE, were not degraded under aerobic conditions. None of these experiments were conducted with the addition of methane. Wilson and Wilson (1985) first documented aerobic cometabolism of TCE with methanotrophic bacteria in an aerobic soil column environment adding natural gas and oxygen. This was followed by results from other researchers obtaining similar results but only with the addition of an energy source such as methane (Bouwer and McCarty, 1983; Fogel et al., 1986; Barrio-Lage et al., 1987). These results explain the apparent confusion by many individuals in the environmental industry on whether aerobic degradation of TCE is possible. Typically, methane oxidizing bacteria are found at the capillary fringe of a groundwater system (Hanson, 1980).

The cometabolic reaction is initiated when methanotrophic microorganisms produce a methane monooxygenase enzyme needed for methane reduction. A solvent present is in competition with methane for the oxidation site (Strand et al., 1990). The biological dechlorination of TCE results in a TCE epoxide which is further reduced to dichloroacetic and glyoxylic acid, carbon dioxide, and chloride (Little et al., 1988). In this process, methane is not completely broken down and thus tends to accumulate in the groundwater system. Although the aquifer system must have sufficient levels of methane present to facilitate this reaction (Little et al., 1988), too much methane has a negative effect on the reaction (Lanzarone and McCarty, 1990; Oldenhuis et al., 1991; and Semprini et al., 1991). Cis-1,2-DCE and VC which are typically seen in anaerobic degradation are not produced in the cometabolic reaction with methane (McClellan et al., 1989 and Malachowsky et al., 1994). However, some of the intermediary degradation products, such as carbon monoxide, have been suggested to inhibit TCE degradation in some situations due to their toxicity to microorganisms (Alvarez-Cohen and McCarty, 1991 and Henry and Grbic-Galic, 1991). This may explain why different cultures of bacteria have 
varying successes in degrading TCE. A study by Broholm et al. (1993) found only three of eight cultures removed TCE at a sufficient rate to be measured. The methanotrophic bacteria are attached to the aquifer matrix and degrade TCE sorbed to this surface. Ball and Roberts (1991) suggest the length of time TCE is sorbed onto the aquifer matrix, allowing the formation of residues difficult to desorb, may explain why aerobic degradation is not more common.

The cometabolic reaction efficiency of TCE and cis-1,2-DCE was lower than trans-1,2-DCE and VC (Murray and Richardson, 1993: Vogel, 1994; McCarty and Semprini, 1994; and Hopkins and McCarty, 1995). Rates of cometabolism increase as the degree of dechlorination decreases (Vogel, 1994). The more chlorinated compounds, such as TCE, can be toxic to some microorganisms depending on the TCE concentration levels (Oldenhuis et al., 1989). Additionally, the removal efficiency of TCE decreased with increasing TCE levels, although with the addition of phenol a maximum transformation concentration of $1400 \mu \mathrm{g} / \mathrm{L}$ might be obtained (Hopkins and McCarty, 1995). Strand et al. (1990) derived a rate constant of $3.7 \times 10^{-4} \mathrm{~L} / \mathrm{mg}$ for TCE degradation at a concentration of $3 \mathrm{mg} / \mathrm{L}$. The activity of the methanotrophic culture ceased at a concentration of $7.7 \mathrm{mg} / \mathrm{L}$ TCE (Strand et al., 1990). Malachowsky et al. (1994) found individual isolates could not degrade TCE at concentrations greater than $10 \mathrm{mg} / \mathrm{L}$ and bacterial mixtures were limited to $150 \mathrm{mg} / \mathrm{L}$, which is approximately ten percent of the solubility limit of TCE. Mu and Scow (1994) found similar limits for TCE degradation near $50 \mathrm{mg} / \mathrm{L}$, suggesting at certain levels TCE becomes toxic to the microorganisms. For comparison, TCE levels in the core of the Northwest Plume as far as the DOE property boundary exceed 20 $\mathrm{mg} / \mathrm{L}$.

\subsection{CONTAMINANT DISAPPEARANCE}

One of the methods to consider whether NA plays a significant role in contaminant reduction is by looking at contaminant concentrations along the axial flowpath of the plume. A single flow line is picked out downgradient of a source and traced out. A suitable selection of monitoring wells was available for the Northwest Plume, however the location of available monitoring wells in the Northeast Plume did not allow a proper axial transect. Therefore, the analysis of NA for the Northeast Plume may be affected by the non-ideal placement of monitoring wells. Another approach is to evaluate contaminant concentrations within a given well. If concentrations decline with time, then a given plume may be a candidate for NA. Also, if concentrations decrease with increasing distance from the source then a given plume is a possible candidate for NA. Declining concentrations do not prove contaminants are being destroyed since the observed reduction maybe the result of factors such as advection, dispersion, dilution, sorption, etc.

The role of sorption of ${ }^{99} \mathrm{Tc}$ at PGDP was evaluated by Gu and Dowlen (1996) who found no measurable evidence for the sorption or precipitation of ${ }^{99} \mathrm{Tc}$ onto RGA sediments. Thus, the measured partitioning coeffecient $\left(\mathrm{K}_{d}\right)$ for ${ }^{99} \mathrm{Tc}$ was less than 0.01 , which yields a retardation factor of 1.0 , i.e. no significant retardation. Essentially, ${ }^{99} \mathrm{Tc}$ behaves as a conservative tracer at PGDP. Similar studies evaluating TCE sorption onto sediments at PGDP have not been performed. Previous work by $\mathrm{CH} 2 \mathrm{M}$ Hill (1990 and 1992) and Clausen et al. (1993 and 1995a) derived a TCE $\mathrm{K}_{d}$ of approximately 1.0 based on measured fraction of organic carbon $\left(f_{o c}\right)$ values of 0.001 to 0.002 . The $K_{d}$ approach assumes a sorption partitioning coefficient is concentration independent. Nonlinear organic solvent sorption isotherms in low $\mathrm{f}_{\mathrm{oc}}$ aquifer sediments has been documentated by Curtis et al. (1986) and Ball and Roberts (1991). Recent work by Allen-King et al. (1996) indicates the $K_{d}$ technique significantly under predicts sorption. This observation has also been noted by other researchers for low carbon aquifer systems (Curtis et al., 1986; Piwoni and Banerjee, 1989; Ball and Roberts, 1991; and Ball and Roberts, 1992). Thus, sorption of TCE onto clay particles at PGDP within the RGA may have been significantly underestimated in the previous work by CH2M Hill (1990 and 1992) and Clausen et al. (1993 and 
1995a). Allen-King et al. (1996) have reported sorption underestimates for solvents as high as a factor of 20 . Therefore, sorption of TCE may play a more important role as an attenuating mechanism in the RGA at PGDP than previously believed.

Fryar (1997) reports evidence for discharge of RGA water into surface water near the Ohio River. Dispersion and dilution could be a significant mechanism once the plumes discharge into the Ohio River. Calculations performed indicate TCE levels will be well below current analytical methodologies (Clausen et al., 1995a). Surface water bodies present such as lake sediments and wetlands may also have conditions suitable for anaerobic processes (Mitsch and Gosselink, 1993; and Pardue et al., 1993; Chiang et al., 1997; Fryar et al., 1997). However, a more significant mechanism would be volatilization of TCE owing to its high vapor pressure. A change in redox chemistry has the potential for sorption and reductive dechlorination of TCE as well as sorption and precipitation of ${ }^{99} \mathrm{Tc}$. Additionally, phytoreduction of contaminants such as TCE and hypoaccumulation and immobilization of metals has been documented.

Solute plumes stabilize due to precipitation, sorption, diffusion, advection, dispersion, dilution and biogeochemical transformations. Dilution results from both mechanical mixing and molecular diffusion. Dispersion is a multidirectional process with vertical and transverse dispersive processes being less than longitudinal processes which results in the typical long and narrow plumes, such as the ones at PGDP. The concept of plume stabilization was presented by Clausen et al. (1995a) for the Northwest Plume and is based on a TCE and 99Tc concentration decline with distance. The concept assumes that eventually a point is reached that the flux rate from the source is equivalent to advective processes at the leading edge of the plume. An example of a stable plume in an advective flow field is smoke or steam emanating from stack emissions. Clausen et al. (1995a) predicted the Northwest Plume would stabilize at a distance of approximately $14,000 \mathrm{ft}$ from the source based on the TCE concentration decline in the plume. Computer modeling by Solomon (1995) yielded an estimate of less than $20,000 \mathrm{ft}$ for plume stabilization to occur. The concept of groundwater plume stabilization as an indicator of NA has only been recognized in the past several years based on the study of hundreds of petroleum hydrocarbon plumes (Nyer and Gearhart, 1997).

Other trending methods are to evaluate the concentrations of a contaminant from a well located within the contaminant plume. Trending analysis provides more robust results with increasing observations and length of time. In general, monitoring wells in a plume considered to be a candidate for NA, exhibits stable or declining levels of the contaminant. Although seasonal variations in concentration levels are expected, over a time period of years, the overall trend should be downward or a stabilized concentration level should be apparent. If contaminant concentrations in a given well are increasing with time, then the plume is not a candidate for NA (EPA, 1997).

\subsection{LOSS OF ELECTRON ACCEPTORS AND ACCUMULATION OF DEGRADATION PRODUCTS}

Wiedemeier et al. (1996) developed a screening criteria for assessing the viability of biodegradation as an NA process through the analysis of geochemical as well as biological parameters. The application of the screening process consists of sampling wells along the centerline of the plume, upgradient of source, immediately downgradient of source, and downgradient of the plume for the geochemical parameters in Table 2. One approach to evaluate biodegradation is by indirect evidence such as the 1) decline in parent concentration and increase in metabolic byproducts along the flow path. Additional evidence used is the 2) presence and concentrations of electron acceptors and donors. This information can also be useful if bioagumentation of organic solvent plume is considered in addition to NA or as a stand alone technology. Wiedemeier et al. (1996) 
developed a guideline to assess the biodegradation potential using the criteria in Table 2 . The criteria uses a ranking system to estimate the potential for reductive dehalogenation (Table 3). If analysis of a site is inconclusive for steps one and two, then 3) laboratory and/or field microcosm studies may be warranted. In general, Wiedemeier et al. (1996) recommend steps one and two be performed first and then step three, if needed. The drawback of microcosm studies is the cost, as well as the length of time to perform a thorough rate study (6 to 18 months). Additionally, there are some questions to the applicability of laboratory generated biodegradation rates for estimating field or "in-situ" rates.

\subsection{ADDITIONAL MONITORING PARAMETERS}

Analysis of geochemical parameters for evaluation of the NA of metals and radionculides is still in its infancy. To date, no published guidelines exist to direct an NA evaluation. However, similar observational trends exhibited by organic compounds may be applied to the metals. The analysis can include evaluation of concentration trends along the axis of a plume, as well as from monitoring wells located within the plumes. One of the key components in evaluating NA for metals is identifying the metal form of the contaminant, associated sorption/desorbtion kinetics, and bioavailability.

\section{FIELD AND ANALYTICAL METHODS}

The NA criteria discussed in Section 2 shaped the approach used in this study. A total of 15 wells were sampled as part of the NA study on May 12 through 15, 1997 (Figure 2). The sampling locations include six wells in the Northwest Plume, five wells in the Northeast Plume, two wells which serve as the source of both the Northwest and Northeast Plumes (one each, in the UCRS and RGA), and two background wells. Fourteen of the wells are completed in the uppermost aquifer of interest, the RGA. Two wells are completed in the UCRS near the source areas. Monitoring well MW262 was sampled twice and served as the duplicate. The location, distance from source, and depth are presented in Table 4. The selection of well sampling locations was patterned after the recommended approach in Wiedemeier et al. (1996). 
Table 2. Screening criteria for an NA assessment for chlorinated solvents

\begin{tabular}{|c|c|c|c|}
\hline Analysis & $\begin{array}{c}\text { Concentration in } \\
\text { Most } \\
\text { Contaminated } \\
\text { Zone } \\
\end{array}$ & Interpretation & Value \\
\hline Oxygen & $\begin{array}{l}<0.5 \mathrm{mg} / \mathrm{L} \\
>1 \mathrm{mg} / \mathrm{L}\end{array}$ & $\begin{array}{l}\text { Higher concentrations suppress reductive pathway } \\
\text { VC may be oxidized aerobically }\end{array}$ & $\begin{array}{c}3 \\
-3\end{array}$ \\
\hline Nitrate & $<1 \mathrm{mg} / \mathrm{L}$ & $\begin{array}{l}\text { Higher concentrations may compete with reductive } \\
\text { pathway }\end{array}$ & 2 \\
\hline Iron (II) & $>1 \mathrm{mg} / \mathrm{L}$ & Reductive pathway possible & 3 \\
\hline Sulfate & $<20 \mathrm{mg} / \mathrm{L}$ & $\begin{array}{l}\text { Higher concentrations may compete with reductive } \\
\text { pathway }\end{array}$ & 2 \\
\hline Sulfide & $>1 \mathrm{mg} / \mathrm{L}$ & Reductive pathway possible & 3 \\
\hline Methane & $\begin{array}{l}<0.5 \mathrm{mg} / \mathrm{L} \\
>0.5 \mathrm{mg} / \mathrm{L}\end{array}$ & $\begin{array}{l}\text { VC oxidizes } \\
\text { VC accumulates }\end{array}$ & 3 \\
\hline$\overline{\mathrm{Eh}}$ & $\begin{array}{l}<50 \mathrm{mV} \\
<-100 \mathrm{mV}\end{array}$ & $\begin{array}{l}\text { Reductive pathway possible } \\
\text { Reductive pathway likely }\end{array}$ & $\begin{array}{l}1 \\
2\end{array}$ \\
\hline $\mathrm{pH}$ & $\begin{array}{l}5<\mathrm{pH}<9 \\
5>\mathrm{pH}>9 \\
\end{array}$ & $\begin{array}{l}\text { Optimal range for reductive pathway } \\
\text { Outside optimal range }\end{array}$ & $\begin{array}{l}0 \\
-2\end{array}$ \\
\hline TOC & $>20 \mathrm{mg} / \mathrm{L}$ & Carbon source for biochemical processes & 2 \\
\hline Temperature & $>20^{\circ} \mathrm{C}$ & At $\mathrm{T}>20^{\circ} \mathrm{C}$ biochemical processes accelerated & 1 \\
\hline Carbon Dioxide & $>$ 2X Background & Ultimate oxidative daughter product & 1 \\
\hline Alkalinity & $>2 \times$ Background & Interaction of $\mathrm{CO}_{2}$ with aquifer matrix & 1 \\
\hline Chloride & $>2 \times$ Background & Daughter product of organic chlorine & 2 \\
\hline Hydrogen & $\begin{array}{l}>1 \mathrm{nM} \\
<1 \mathrm{nM} \\
\end{array}$ & $\begin{array}{l}\text { Reductive pathway possible } \\
\text { VC oxidized }\end{array}$ & $\begin{array}{l}3 \\
0\end{array}$ \\
\hline $\begin{array}{l}\text { Volatile Fatty } \\
\text { Acids }\end{array}$ & $>0.1 \mathrm{mg} / \mathrm{L}$ & Intermediate of biodegradation & 2 \\
\hline BTEX & $>0.1 \mathrm{mg} / \mathrm{L}$ & Drives dechlorination & 2 \\
\hline TCE & & Material Released & \\
\hline cis-1,2-DCE & & Daughter product of TCE & $2^{a}$ \\
\hline$\overline{V C^{2}}$ & & Daughter product of DCE & $2^{\mathrm{B}}$ \\
\hline Ethene/Ethane" & $\begin{array}{l}>0.01 \mathrm{mg} / \mathrm{L} \\
>0.1 \mathrm{mg} / \mathrm{L}\end{array}$ & Daughter product of VC/ethene & $\begin{array}{l}2^{a} \\
3^{a}\end{array}$ \\
\hline Chloroethane" & & Daughter product of VC & $2^{\mathrm{a}}$ \\
\hline 1,1-DCE & & Daughter product of TCE & $2^{8}$ \\
\hline
\end{tabular}

- Points awarded only if the compound is a daughter product and not a constituent of the source DNAPL. Modified from Wiedemeier et al., 1996. 
Table 3. Potential for anaerobic bioremediation

\begin{tabular}{|c|l|}
\hline Score & \multicolumn{1}{|c|}{ Interpretation } \\
\hline 0 to 5 & Inadequate evidence for biodegradation of chlorinated organics \\
\hline 6 to 14 & Limited evidence for biodegradation of chlorinated organics \\
\hline 15 to 20 & Adequate evidence for biodegradation of chlorinated organics \\
\hline$>20$ & Strong evidence for biodegradation of chlorinated organics \\
\hline
\end{tabular}

Table 4. Summary of monitoring well information

\begin{tabular}{|c|c|c|c|l|}
\hline $\begin{array}{c}\text { Well } \\
\text { Number ID }\end{array}$ & $\begin{array}{c}\text { Unit } \\
\text { Monitored }\end{array}$ & $\begin{array}{c}\text { Depth of } \\
\text { Well Screen } \\
(\mathrm{ft})\end{array}$ & $\begin{array}{c}\text { Distance From } \\
\text { Primary Source } \\
\text { (ft) }\end{array}$ & \multicolumn{1}{|c|}{ Location } \\
\hline \hline MW157 & UCRS & $30-35$ & 0 & $\begin{array}{l}\text { Immediate Vicinity of NW and NE Plume } \\
\text { Source, C-400 }\end{array}$ \\
\hline MW155 & top RGA & $63-70$ & 0 & $\begin{array}{l}\text { Immediate Vicinity of NW and NE Plume } \\
\text { Source, C-400 }\end{array}$ \\
\hline MW262 & base RGA & $90-95$ & 1750 & $\begin{array}{l}\text { Within NW Plume, Downgradient C-400 } \\
\text { Source, Upgradient C-749-A Source }\end{array}$ \\
\hline MW187 & UCRS & $21.6-26.5$ & 0 & Immediate Vicinity of C-749-A Source \\
\hline MW66 & top RGA & $55.2-60.2$ & 3000 & $\begin{array}{l}\text { Within NW Plume, Downgradient C-400 } \\
\text { Source and Immediate Vicinity of C-749-A } \\
\text { Source }\end{array}$ \\
\hline MW248 & top RGA & $65-75$ & 4500 & Within NW Plume \\
\hline MW233 & top RGA & $69-79$ & 11,500 & Within NW Plume \\
\hline MW146 & top RGA & $57.4-67.4$ & 16,250 & Leading Downgradient Edge of NW Plume \\
\hline MW108 & RGA & $67-97$ & 1575 & $\begin{array}{l}\text { Within NE Plume and Immediate Vicinity of } \\
\text { possible C-333 Source }\end{array}$ \\
\hline MW255 & base RGA & $91-96$ & 4075 & $\begin{array}{l}\text { Within NE Plume and Immediate Vicinity of } \\
\text { possible Kellogg Source }\end{array}$ \\
\hline MW193 & top RGA & $58-63$ & 6500 & Downgradient Lateral Periphry of NE Plume \\
\hline MW124 & base RGA & $55-65$ & 7500 & Within NE Plume \\
\hline MW100 & top RGA & $77-87$ & 14,000 & Leading Downgradient Edge of NE Plume \\
\hline MW103 & RGA & $79.5-89.5$ & Background & Background \\
\hline MW194 & RGA & $46.9-51.9$ & Background & Background \\
\hline
\end{tabular}

\subsection{FIELD SAMPLING METHODS}

All of the monitoring wells are constructed of stainless steel and are 2 in. in diameter. The majority of wells have a $5 \mathrm{ft}$ screen as seen in Table 4. All of the monitoring wells are equipped with dedicated Well 
Wizard ${ }^{\mathrm{TM}}$ bladder pumps and packers. Each well is packed off just above the well screen to avoid unnecessary purging of water. The packed off zone, usually $5 \mathrm{ft}$ in length, is purged three times. Packers allow for the collection of a water sample directly from the formation and avoids mixing with the stagnant water column above the well screen. Low-flow purging and sampling methods, flow rates of less than $200 \mathrm{ml} / \mathrm{minute}$, were utilized during the project. Low flow rates have been documented to minimize the disturbance of the water sample and result in less suspension of solids in the water, which can effect reported metal concentrations (Kearl, 1993).

Water samples for anion and alkalinity analyses were collected untreated in 500-mL polyethylene bottles. Volatile Organic Analytes (VOAs) were collected in pre-acidified amber 40-ml VOA vials having septum top lids. ${ }^{99} \mathrm{Tc}$ samples were collected in $250 \mathrm{-ml}$ polyethylene bottles. Samples for oxygen isotope analysis were collected untreated in 30-mL polyethylene bottles. Carbon isotope samples for dissolved inorganic carbon analysis were collected in 10-mL vacutainers. Samples for carbon isotope analysis of TCE were collected in 20-mL crimp-seal EPA vials. Samples for chlorine isotopic samples for analysis of TCE were collected in pre-evacuated 350-mL Schenk tubes having Teflon valves. All samples were placed in a cooler, with ice packs, for transport to the laboratory and then stored in a refrigerator in the laboratory at $4^{\circ} \mathrm{C}$ prior to analysis.

\subsection{ANALYTICAL METHODS}

The parameters analyzed, media sampled, and required reporting limits are presented in Table 5. A single quantification limit is possible for most samples and is based on the method utilized for analysis, except for the volatile organic compounds (VOCs). The quantification limit for VOCs is dependent upon the TCE concentration level and the need for dilution of the sample.

The parameters measured in the field include depth to water, temperature, $\mathrm{pH}, \mathrm{D}$.O., specific conductance, $\mathrm{Eh}$, hydrogen sulfide, ammonia, total and ferric iron. Temperature, $\mathrm{pH}, \mathrm{D} . \mathrm{O}$., and specific conductance were measured with a Hydrolab ${ }^{\mathrm{TM}}$ sampling device with a flow through cell. The flow through cell should minimize the introduction of oxygen to the sample. Good comparison between the Hydrolab ${ }^{\mathrm{TM}}$ and gaseous extraction method for D.O. indicated the flow cell minimized the introduction of atmospheric oxygen to the sample. A second set of analysis for temperature, $\mathrm{pH}$ and Eh were collected in the field using a portable Orion meter by Argonne National Laboratory (ANL). The Orion meter utilizes a platinum electrode for Eh analysis. The $\mathrm{pH}$ numbers reported in this study are those collected with Hydrolab ${ }^{\mathrm{TM}}$ and an enclosed flow-through cell. The water samples have significant levels of $\mathrm{CO}_{2}$ and exposure of the samples to the atmosphere resulted in degassing of $\mathrm{CO}_{2}$ and subsequent increase in $\mathrm{pH}$ values. Therefore, the $\mathrm{pH}$ values obtained with the Hydrolab ${ }^{\mathrm{TM}}$ were

reported. Hydrogen sulfide, ammonia, and total iron concentrations were analyzed in the field using Hach test kits. (Hach, 1992).

The parameters measured by ANL included nitrate, chloride, sulfate, oxygen isotope ratios in water, carbon isotope ratios in DIC, carbon isotope ratios in TCE, and chlorine isotope ratio analysis of TCE. The anions (nitrate, chloride, sulfate) were analyzed by ion chromatography using a Dionex system. In addition, a gaseous extraction technique was utilized to measure gas phases of D.O., $\mathrm{CO}_{2}$, hydrogen, methane, nitrogen, and argon. 
Table 5. Parameters and reporting limits for the NA study

\begin{tabular}{|l|l|l|}
\hline Parameter & Media & Reporting Limits \\
\hline \hline Hydrogen & Gas & $0.22 \mathrm{ppm}$ \\
\hline Methane & Gas & $0.1 \mathrm{ppm}$ \\
\hline Argon & Gas & 0.018 \\
\hline Dissolved Oxygen & Gas & $0.1 \mathrm{ppm}$ \\
\hline Methane & Gas & $0.001 \mathrm{ppm}$ \\
\hline Nitrogen & Gas & $0.013 \mathrm{ppm}$ \\
\hline Nitrate Nitrogen & Water & $1 \mathrm{mg} / \mathrm{L}$ \\
\hline Ammonia & Water & $0.10 \mathrm{mg} / \mathrm{L}$ \\
\hline Sulfate & Water & $10 \mathrm{mg} / \mathrm{L}$ \\
\hline Hydrogen Sulfide & Water & $0.01 \mathrm{mg} / \mathrm{L}$ \\
\hline Total Iron & Water & $0.1 \mathrm{mg} / \mathrm{L}$ \\
\hline Ferrous Iron & Water & $0.1 \mathrm{mg} / \mathrm{L}$ \\
\hline DOC & Water & $1 \mathrm{mg} / \mathrm{L}$ \\
\hline Alkalinity & Water & $1.0 \mathrm{mg} / \mathrm{L}$ \\
\hline Chloride & Water & $0.1 \mathrm{mg} / \mathrm{L}$ \\
\hline Sulfate & Water & $0.1 \mathrm{mg} / \mathrm{L}$ \\
\hline TCE* & Water & $0.001 \mathrm{mg} / \mathrm{L}$ \\
\hline cis,, $1-2-D C E^{*}$ & Water & $0.001 \mathrm{mg} / \mathrm{L}$ \\
\hline $1,1-D C E^{*}$ & Water & $0.005 \mathrm{mg} / \mathrm{L}$ \\
\hline Vinyl Chloride* & Water & $0.003 \mathrm{mg} / \mathrm{L}$ \\
\hline Chloroethene* & Water & $0.005 \mathrm{mg} / \mathrm{L}$ \\
\hline Ethene & Water & $0.03 \mathrm{mg} / \mathrm{L}$ \\
\hline Ethane & Water & $0.03 \mathrm{mg} / \mathrm{L}$ \\
\hline BTEX & Water & $0.005 \mathrm{mg} / \mathrm{L}$ \\
\hline 99 Tc & Water & $25 \mathrm{pCi} / \mathrm{L}$ \\
\hline pH & Water & $\mathrm{NA}$ \\
\hline Temperature & Water & $1{ }^{\circ} \mathrm{F}$ \\
\hline D.O. & Water & $0.1 \mathrm{mg} / \mathrm{L}$ \\
\hline Eh & Water & $\mathrm{NA}$ \\
\hline
\end{tabular}

- The reporting limit for these compounds varies depending upon the concentration of TCE and the laboratory doing the analysis. The cis-1,2-DCE and VC were analyzed by two methods to obtain a low quantification limit.

Oxygen isotope ratios in water were measured using the $\mathrm{CO}_{2}$ equilibration method of Kishima and Sakai (1980). Analytical precision of the isotope ratios was 0.02 units per mil. Carbon isotope ratios in DIC were measured after $\mathrm{CO}_{2}$ liberation using phosphoric acid (Holt et al., 1995). Analytical precision of the isotope ratios was 0.02 units per mil.

For carbon isotope ratio analysis, TCE was extracted from water samples using solid-phase microextraction. Carbon isotope ratios in TCE were then measured by gas chromatography-combustion-isotope 
ratio mass spectrometry using a VG Optima system. Analytical precision of the carbon isotope ratios ranged from 0.03 to 0.08 units per mil.

For chlorine isotope ratio analysis of TCE, the TCE was stripped from the water using a vacuum extraction technique (Holt et al., 1995). TCE was then sealed in a pyrex combustion tube with $\mathrm{CuO}$ and combusted at $550^{\circ}$ $\mathrm{C}$ for two hours, following the method of Holt et al. (1997). Combustion products included $\mathrm{CuCl}$, that was distilled away from the residual $\mathrm{CuO}$ at $700^{\circ} \mathrm{C}$ and then reacted with $\mathrm{CH}_{3} \mathrm{I}$ to produce $\mathrm{CH}_{3} \mathrm{Cl}$. $\mathrm{CH} \mathrm{Cl}$ was purified by cryogenic distillation and then introduced into a VG Prism Series II gas-source isotope ratio mass spectrometer. Analytical precision of the chlorine isotope ratios ranged from 0.02 to 0.05 units per mil.

Volatile compounds were analyzed by LMUS using RCRA method 8260, purge-and-trap, with a Hewlett Packard gas chromatograph/mass spectroscopy, model 5790, with a megabore $0.53 \times 60 \mathrm{~m}$ capillary column. The quantification limit for the undiluted water samples is $0.001 \mathrm{mg} / \mathrm{L}$ for TCE. Samples with elevated levels of TCE will have a higher quantification limit for the other VOCs analyzed due to the need of dilution, and this level will vary depending on the TCE concentration level. To obtain a lower quantification limit for cis-1,2-DCE and VC a split sample was sent to an onsite laboratory run by Camp Dresser McKerr (CDM) for analysis using a purge-and-trap gas chromatograph with a electrolytic capture detector following EPA Method 8010. A quantification limit of 0.001 and $0.003 \mathrm{mg} / \mathrm{L}$ was obtained for cis-1,2-DCE and VC, respectively.

${ }^{99}$ Tc was measured by LMUS using a modified EPA Method 900 , liquid scintillation counting, following methylethylketone extraction. The quantification limit for ${ }^{99} \mathrm{Tc}$ is $25 \mathrm{pCi} / \mathrm{L}$.

\section{QUALITY ASSURANCE/QUALITY CONTROL}

All sampling performed in accordance with medium-specific procedures followed the PGDP Environmental Restoration and Enrichment Facilities Field Operations Procedures Manual (MMES, 1993). These procedures are consistent with the LMES Environmental Surveillance Procedures (Kimbrough et al., 1990) and the EPA Region IV Standard Operating Proceduress.

\subsection{GROUNDWATER SAMPLING}

Field quality control (QC) sampling was conducted to check sampling analytical accuracy and precision for both laboratory and field analyses of collected samples. Three different types of field QC samples were collected during implementation of the investigation: trip blanks, field blanks, and field duplicates. One well, MW262, was sampled in duplicate.

A trip blank consisted of a sealed container of ASTM Type II water prepared in the laboratory. The trip blank traveled with samples collected in the field and was transported to the laboratory for VOCs analysis. Trip blanks are used to identify contaminants, specifically VOCs, originating during transport of the samples from the field. One trip blank accompanied each cooler of samples to the field laboratory.

A field blank consisted of a sealed container of ASTM Type II water that traveled with the sample bottles into the field. One field blank was collected during the course of the study. The field blank consisted of a 40-mL VOA vial filled with deionized water in the laboratory. The vial was taken to the field where the cap was 
removed for a brief period and replaced. Each vial was properly labeled and returned to the field laboratory for analysis.

A field duplicate was collected along with a field sample and placed into a separate set of containers labeled with a different sample number. One field duplicate was submitted "blind" to the laboratory and used to indicate whether the field sampling technique was reproducible and to ensure the accuracy of reported laboratory results.

Field documentation maintained throughout the investigation consisted of various types of documents including a site logbook, field logbook, sample labels, sample tags, chain-of-custody forms, and field data sheets. Sample identification, numbering, and labeling was performed in accordance with PGDP Field Operation Procedure CP4-ER-SAM2001. Field documentation conformed to PGDP CP4-ER-A1101. Additionally, comparisons were made between data collected in this study (Appendix A) and historical data for the same wells (Appendix B) with no notably discrepancies.

\subsection{ANALYTICAL PROTOCOL}

The CDM onsite gas chromatograph was calibrated using standards of $5,10,20,40$, and $80 \mathrm{ppb}$ using a correlation coefficient of 0.995 or greater. Cis-1,2-DCE and VC samples were analyzed undiluted. The following laboratory QC samples were run: laboratory duplicate, laboratory blank, and continuing calibration check. Laboratory quality control criteria followed those specified in KY/EM-110, Rev. 1, Field Laboratory Quality Assurance Plan.

\subsection{DISCUSSION AND RESULTS}

\subsection{GENERAL GROUNDWATER GEOCHEMISTRY}

The general groundwater characteristics for both plumes as measured in this study are: $\mathrm{pH}, 5.7$ - 6.8; Eh, +120 to $+280 \mathrm{mV}$; D. O., 1.0 - 7.9; bicarbonate, 99 - $351 \mathrm{mg} / \mathrm{L}$; chloride, 3 - $120 \mathrm{mg} / \mathrm{L}$; sulfate, 5.5 - $115 \mathrm{mg} / \mathrm{L}$; nitrate, $<0.5-50 \mathrm{mg} / \mathrm{L}$; total iron< $0.3-7.0 \mathrm{mg} / \mathrm{L}$; hydrogen sulfide $\left(\mathrm{H}_{2} \mathrm{~S}\right),<0.01-0.04 \mathrm{mg} / \mathrm{L}$; and ammonia, $<0.1 \mathrm{mg} / \mathrm{L}$ (Appendix A). The D.O. and Eh values are consistent with an aerobic aquifer system. Background D.O. levels were measured at 3.1 and $4.9 \mathrm{mg} / \mathrm{L}$. However, there may be micro environments of oxic-limited conditions within the RGA, such as near MW255, which exhibited a D.O. value of $0.7 \mathrm{mg} / \mathrm{L}$. Similar conditions may exist in the UCRS as demonstrated by a D.O. level of $1.0 \mathrm{mg} / \mathrm{L}$ at MW187. Micro sites capable of supporting strict anaerobes were postulated for an aerobic column experiment evaluating TCE degradation (Enzien et al., 1994); similar conditions seem plausible for aquifer systems.

Clausen et al. (1993 and 1995a) previously discussed the low D.O. levels at MW187, as well as elevated cis-1,2-DCE and VC levels as compared to TCE, which were postulated to be suggestive of an anaerobic environment suitable for dechlorination of TCE. Historical records indicate this area was used as a fire training area, and an incinerator was also located nearby (DOE, 1997). These activities may have resulted in a suitable carbon source for anaerobic microorganisms present at the site to utilize. Electron acceptor reactions require an energy source for the degradation of the chlorinated aliphatic organic compounds. However, microbiological activity doesn't necessitate the reduction of a contaminant and may explain why other UCRS wells at PGDP don't exhibit any specific degradation of TCE. As discussed in Section 2, microbiological activity can occur in aerobic as well as anaerobic conditions or change an aerobic environment to anaerobic one. The microbiological 
reduction of a contaminant is dependent on a number of geochemical parameters which act as energy sources and nutrients.

Elevated $\mathrm{CO}_{2}$ levels in RGA groundwater samples suggests biological activity is present in the RGA and is resulting in the consumption of oxygen and generation of $\mathrm{CO}_{2}$. The latter may occur by oxidation of natural soil organic material, abiotic processes, or by both. A plot of oxygen versus bicarbonate indicates D.O. decreases as bicarbonate increases (Figure 8). Furthermore, $\mathrm{pH}$ values for the RGA are slightly acidic even in background locations. A plot of $D$. $O$ versus nitrogen indicates a loss of oxygen, presumably via microbial respiration (Figure 9). Groundwater without microbial activity would plot within the temperature indicator field. All of these indicators suggest aerobic microbiological activity. However, not all microorganisms are capable of degradation of TCE.

The presence of D.O. in excess of $1 \mathrm{mg} / \mathrm{L}$ indicates metabolic processes may be nutrient limited or active replenishment of oxygenated water is occurring, or both. Previous age dating of the RGA at the Northwest Plume using tritium/helium techniques suggested very old "pre-bomb" water or very young groundwater (Clausen et al., 1995a). The previous age dating results, combined with this study, suggest the RGA may consist of recently recharged water. This observation appears to conflict with the site lithology, i.e. relatively low to moderate permeability clays and sand lenses with hydraulic conductivities in the range of $10^{-4}$ to $10^{-8} \mathrm{~cm} / \mathrm{s}$. However, presence of fractures could be an avenue allowing for rapid recharge of groundwater. Clausen et al., 1993 postulated fractures may play an important role in contaminant transport at PGDP. Furthermore, Laase and Clausen (1997) conducted a modeling exercise which indicated industrial recharge from leaking utility lines may play a role in contaminant transport.

\subsection{CONTAMINANT GEOCHEMISTRY}

The contaminant chemistry profile within the Northwest and Northeast Plumes is reported in Clausen et al. (1993 and 1995a) and DOE (1996). As reported in Clausen et al. (1995a) the concentration of TCE and ${ }^{99} \mathrm{Tc}$ within the Northwest Plume declines with distance and may suggest steady-state conditions based on eight years of monthly to quarterly data. However, data from wells MW66, R2, and R113 (not reported) located within the core of the Northwest plume exhibited increasing concentration trends for TCE starting in 1994 (Figures 2, 10, and 11). Monitoring wells R2 and R113 are located near the center of the Northwest Plume where it intersects Ogden Landing Road (Figure 2). The intra-well increasing concentration trends suggest the core of the Northwest Plume is migrating northward. Based on current flow velocities, $1.3 \mathrm{ft} /$ day, TCE levels greater than $5 \mathrm{mg} / \mathrm{L}$ should reach the northern extraction well field within five years. Furthermore, TCE and ${ }^{99} \mathrm{Tc}$ levels in excess of $10 \mathrm{mg} / \mathrm{L}$ and $2500 \mathrm{pCi} / \mathrm{L}$, respectively should reach the northern well field in ten years. However, a factor complicating the analysis are two extraction well fields in the Northwest Plume which began pumping in the fall of 1995. All other wells located in the Northwest Plume exhibit no increasing or decreasing contaminant concentration trends, although the wells do exhibit seasonal changes (Clausen et al., 1993 and 1995a). As discussed in Section 2.3, the distal portion of the Northwest Plume has stabilized, however the hotspot has not reached equilibrium. Monitoring wells within the Northeast Plume (most were installed in 1995) have an insufficient sampling record to make a similar evaluation of concentration through time. 
Figure 8. The relationship of dissolved oxygen to bicarbonate

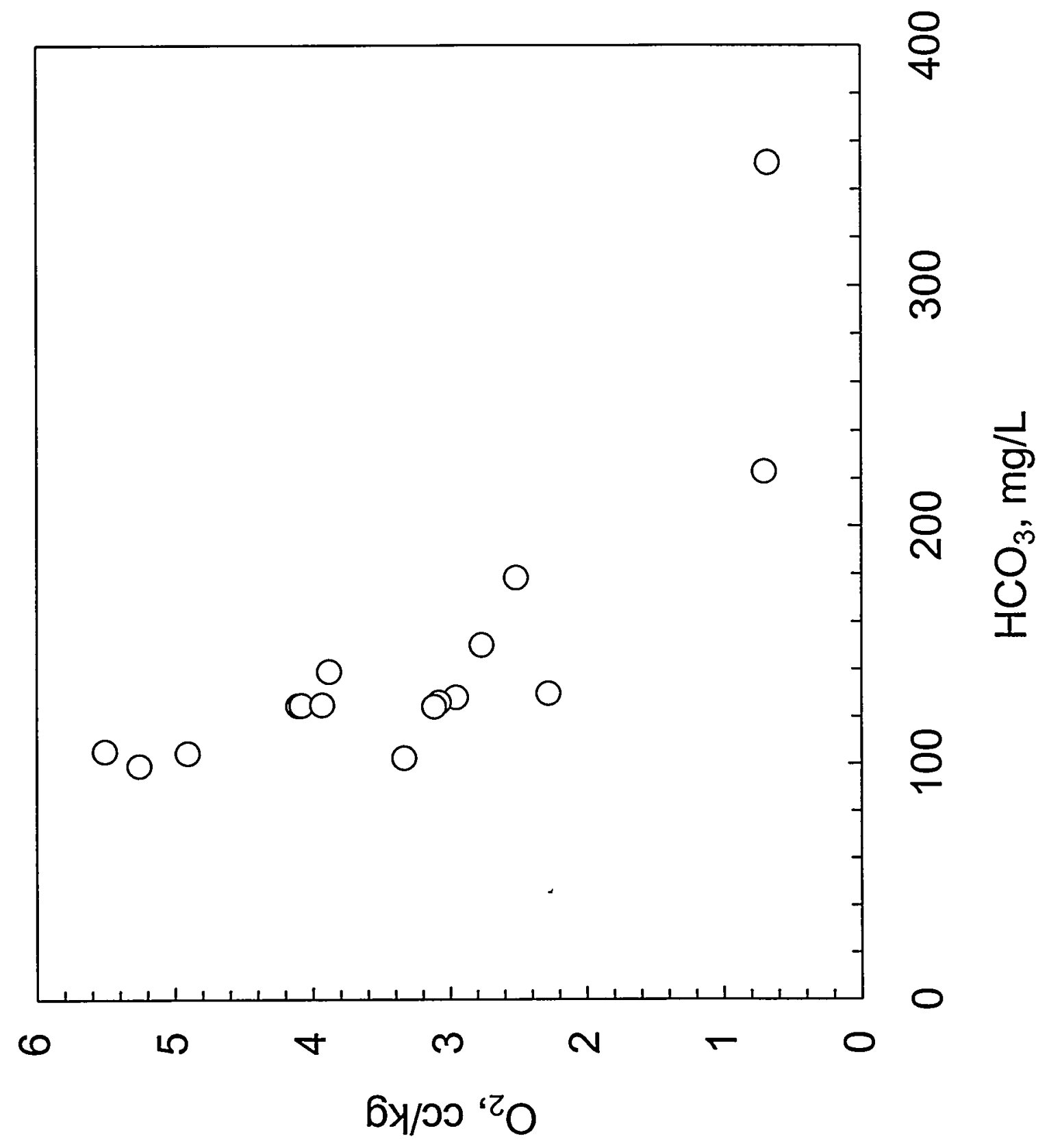


Figure 9. The relationship of dissolved oxygen to nitrogen

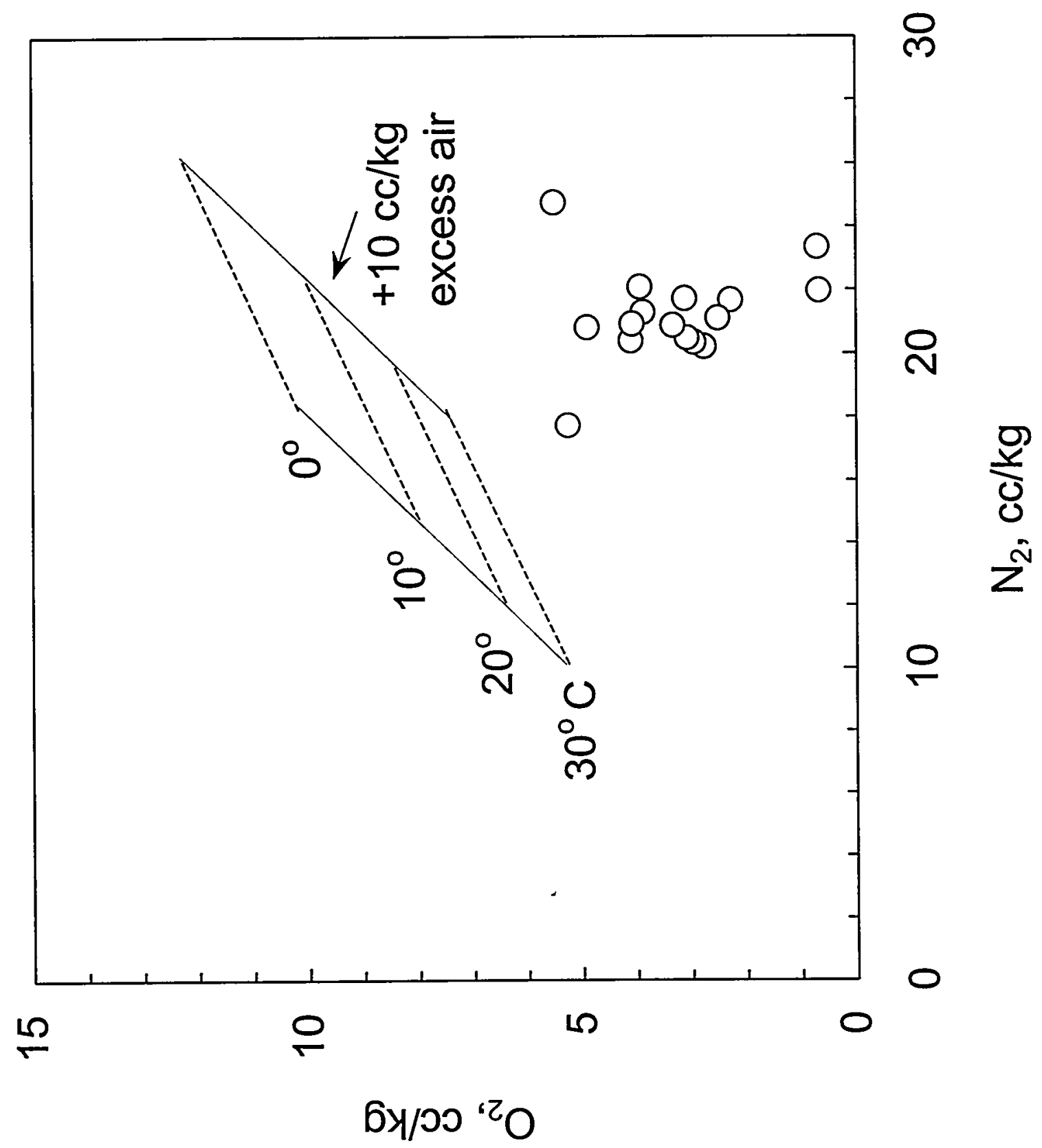


Figure 10. The level of TCE and 99 Tc within the Northwest Plume at MW66 over time

TCE (ug/L) \& Tc-99 (pCi/L)

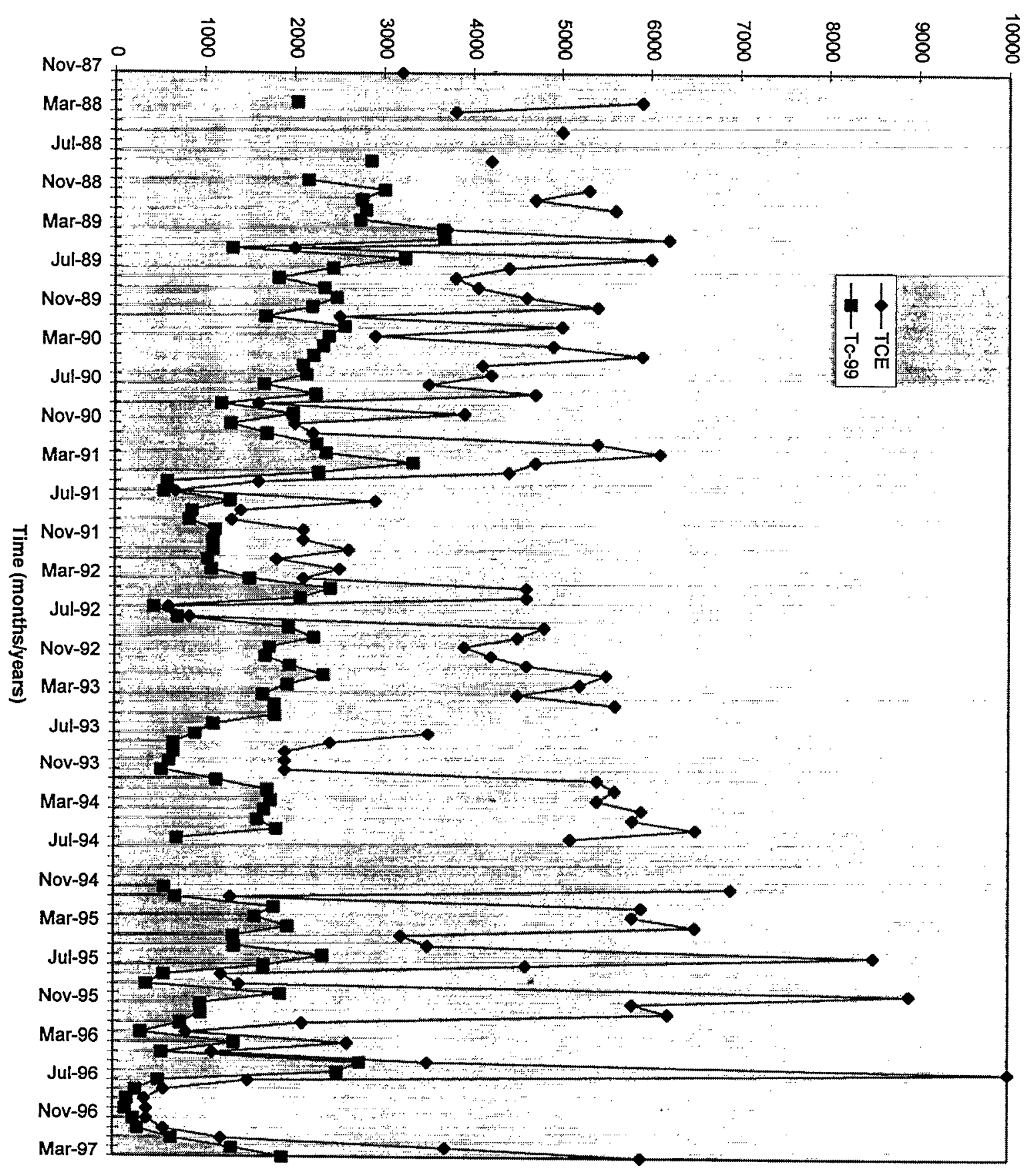


Figure 11. The level of TCE and ${ }^{99}$ Tc within the Northwest Plume at R2 over time

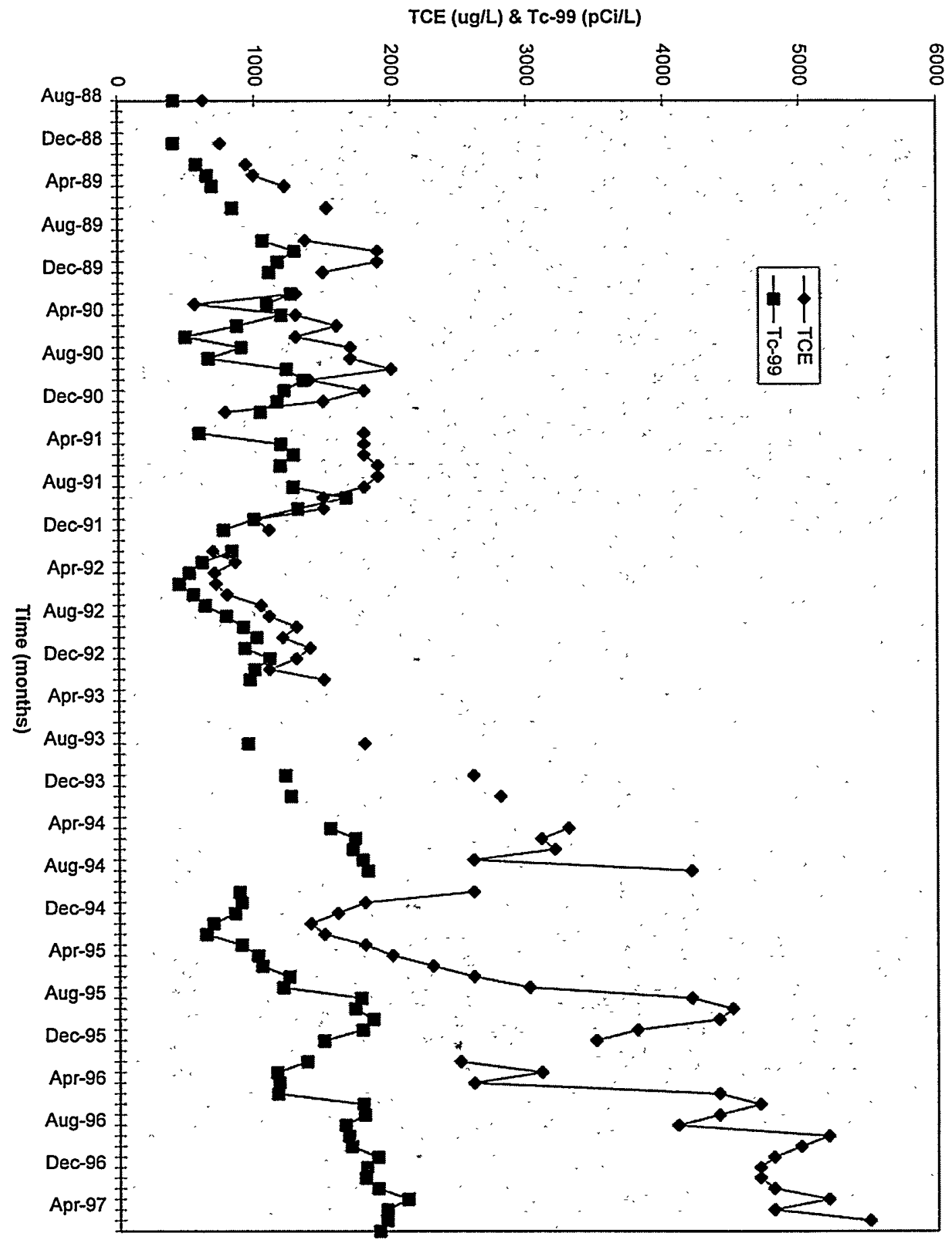


Cis-1,2-DCE was detected in a number of RGA wells. Spatial mapping of the data indicates a general decline with distance from the source. However, the geochemical parameters to be discussed in Section 5.5 are not consistent with active anaerobic biodegradation of TCE. There is a lack of later stage degradation products (VC, ethene, ethane, and chloroethane) which are usually associated with anaerobic biodegradation (Appendix A). Furthermore, cis-1,2-DCE is not a constituent typical of aerobic degradation of TCE, as discussed in Section 2.2.3. Thus, the presence of low levels of cis-1,2-DCE, $<0.01 \mathrm{mg} / \mathrm{L}$, may suggest very limited anaerobic degradation.

\subsection{ISOTOPIC GEOCHEMISTRY}

Isotopic composition is reported in per mil deviation from an isotopic standard reference material using the conventional $\delta$ notation:

$$
\delta=\left(\left(R_{\text {zample }} / R_{\text {ztandard }}\right)-1\right) \times 1000
$$

where

$\mathrm{R}=$ is the isotopic ratio e.g. $\left({ }^{13} \mathrm{C} /{ }^{12} \mathrm{C}\right.$ or $\left.{ }^{37} \mathrm{Cl} / 35 \mathrm{Cl}\right)$.

The isotopic standard reference materials are Pee Dee Belemnite (PDB) for carbon (Craig, 1957), standard mean ocean chloride (SMOC) for chlorine (Lang et al., 1993), and standard mean ocean water (SMOW) for oxygen (Craig, 1961). Oxygen isotope ratios of water $\delta^{18} \mathrm{O}$ from PGDP range from -5.8 to -4.9 per mil. This is a fairly narrow range compared to the typical annual range for the isotopic composition of precipitation at a given continental location. For example, the annual range of $\delta^{18} \mathrm{O}$ values in precipitation at Chicago, IL vary from -19 to -2 per mil (Dansgaard, 1964). There is no obvious systematic spatial variation of the $\delta^{18} \mathrm{O}$ values in PGDP groundwater, and therefore no indication of isotopically distinct recharge sources for the RGA at the site.

There are few published data for stable isotope ratios of chlorinated solvents. Van Warmerdan et al. (1995) show a range of $\delta^{13} \mathrm{C}$ values from -37.2 to -23.3 per mil and a $\delta^{37} \mathrm{Cl}$ range from -3.5 to +6.0 for samples of perchloroethylene, TCE, and trichloroethane from various manufacturers. Holt et al. (1997) provide a range of $8^{13} \mathrm{C}$ values from -58.1 to -24.1 per mil and a range of $8^{37} \mathrm{Cl}$ values from -2.9 to +1.6 per mil for eight chlorinated solvents. The TCE samples collected at PGDP by ANL for isotopic analysis proved problematic for carbon isotopes due to unanticipated high levels of $\mathrm{CO}_{2}$ that interfered with the analysis; insufficient sample volume remained for re-analysis. The ANL sampling procedure has been subsequently improved to allow for the separation of TCE from dissolved $\mathrm{CO}_{2}$, but resampling was not performed for this study. However, carbon isotope ratios of TCE samples at PGDP were determined by gas chromatography-combustion-isotope ratio mass spectrometry using an alternate method which requires substantial less sample volume and yielded results ranging from -30.4 to -26.7 per mil. These $\delta^{13} \mathrm{C}$ values for TCE were obtained from Memorial University using an untested sampling method (in crimp-seal EPA-type headspace vials) and therefore should be used with caution, because of the possibility of isotopic fractionation by interaction with the container materials. The data is not considered further in this report.

Carbon isotope ratios of dissolved inorganic carbon (DIC) at PGDP were measured using a phosphoric acid liberation method (Holt et al., 1995). The resulting $\delta^{13} \mathrm{C}$ DIC values range from -15.4 to -20.0 per mil, and decrease with increasing bicarbonate concentrations (Figure 12). This relationship indicates bicarbonate may be derived from microbial $\mathrm{CO}_{2}$ production from organic material in the aquifer having a relatively low $\delta^{13} \mathrm{C}$ value near -28.0 per mil. 
Chlorine isotope ratios of TCE $\left(8^{37} \mathrm{Cl}\right)$ and dissolved inorganic chloride were determined by the method of Holt et al. (1997). The resulting $8^{37} \mathrm{Cl}$ values range from -1.0 to +2.0 per mil for TCE and +0.3 to +1.4 per mil for chloride. Microbial activity and possible TCE degradation is suggested by the negative correlation of D.O. with $8^{37} \mathrm{Cl}$ of TCE (Figure 13). As the D.O. level decreases the ${ }^{37} 8 \mathrm{Cl}$ of TCE increases suggesting consumption of oxygen by bacteria and reduction of TCE. As TCE is reduced, $\mathrm{Cl}$ ions are liberated by the breakage of the chemical bonds. Furthermore, a plot of normalized $\delta^{37} \mathrm{Cl}$ of TCE versus normalized TCE concentration shows increasing $8^{37} \mathrm{Cl}$ with decreasing TCE concentrations, which is consistent with isotopic fractionation caused by TCE degradation (Figure 14). Two populations are evident and the group with $\delta^{37} \mathrm{Cl}$ of TCE greater than 1.5 per mil are all from wells located along the periphery of both plumes, whereas the group with $8^{37} \mathrm{Cl}$ of TCE values less than 1 per mil are all from wells located within the centroid of the plumes. Correspondingly, the concentration of TCE within the centroid of the plumes is higher than along the periphery. The results suggest that most degradation of TCE is occurring along the periphery of the plumes, but not within the hotspot. The variation in chloride isotope ratios could also be explained by changes in the isotopic signature of the source with time. However, this would seem to be a rather fortuitous occurrence. Further information can be gleaned from the $8^{37} \mathrm{Cl}$ values of TCE by comparing them with $\delta^{37} \mathrm{Cl}$ of dissolved inorganic chloride. (Figure 15). The $8^{37} \mathrm{Cl}$ value of dissolved inorganic chloride in the representative background well (MW-194) is +1.1 per mil. Water samples collected near the source of the plumes show a significant contribution of chloride having relatively low $8^{37} \mathrm{Cl}$ values. As the plume is dispersed, the relative contribution of TCE-produced chloride is small compared to the background chloride.

\subsection{GASEOUS GEOCHEMISTRY}

Hydrogen data for PGDP groundwater contraindicates anaerobic reduction of TCE. Hydrogen was measured by ultrasonic gaseous extraction at ANL using the method of Holt et al. (1995) with a detection limit of $0.22 \mathrm{nM}$. Hydrogen was sampled from wells in both plumes and was reported to be below the detection limit for all samples. Different anaerobic reduction processes give rise to different hydrogen levels (Lovley et al., 1994). Chapelle et al. (1995) describe how the rate of hydrogen production and consumption can be utilized as a single indicator of the reductive microbial mechanism. Typically, hydrogen concentrations less than $0.1 \mathrm{nM}$ are indicative of nitrate reduction in anaerobic groundwater (Lovley and Goodwin, 1988). Furthermore, hydrogen concentrations in the 0.1 to $0.8 \mathrm{nM}$ range are indicative of $\mathrm{Fe}$ (III) reduction (Chapelle and Lovley, 1992). Sulfate reduction is indicated by hydrogen concentrations in the 1.0 to $4.0 \mathrm{nM}$ range and methanogenesis by hydrogen in the 5 to $25 \mathrm{nM}$ range (Vroblesky and Chapelle, 1994). To test the hydrogen analysis, a comparison was made with the typical approach of evaluating electron acceptors.

\subsection{EVALUATION OF BIODEGRADATION}

A comparison of electron acceptor results against screening criteria developed by Wiedemeier et al. (1996) suggests anaerobic biodegradation is not an NA process in the Northwest and Northeast Plumes. The screening criteria followed were presented in Section 2.4 . Screening results yielded a value of $(-1)$, strongly suggesting anaerobic biodegradation is not occurring in the RGA (Table 6). The wells located in the most concentrated part of the plumes used for the analysis include MW66, MW233, MW248, and MW262 in the Northwest Plume and MW108, MW155, and MW255 in the Northeast Plume. Background wells used for comparison were MW103 and MW194. None of the indicators usually associated with anaerobic processes; e.g., elevated ferrous iron, sulfide, methane, $\mathrm{CO}_{2}$, or hydrogen was detected or significantly above background levels (Table 6). 


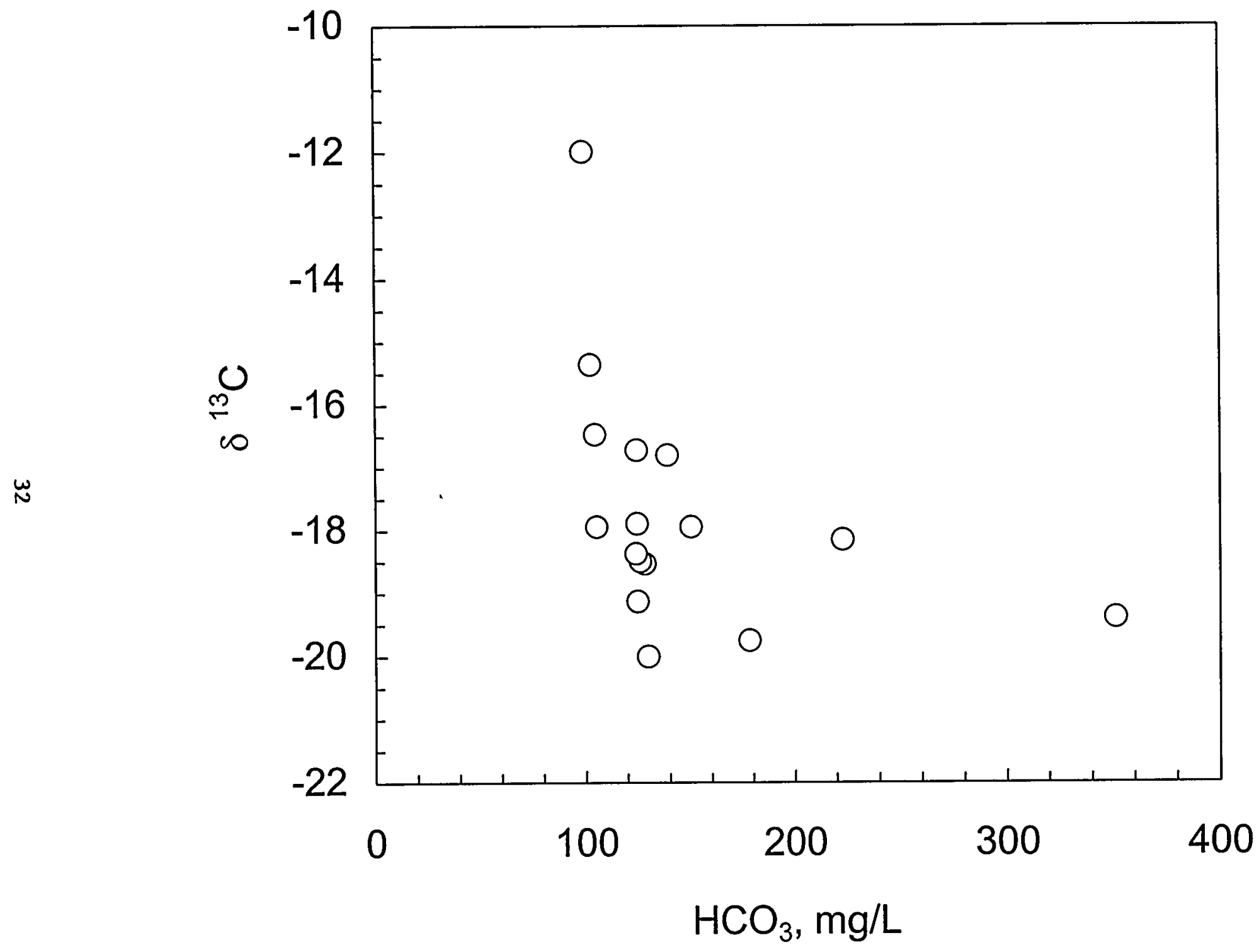


Figure 13. The relationship of dissolved oxygen to $8^{37} \mathrm{Cl}$ of TCE

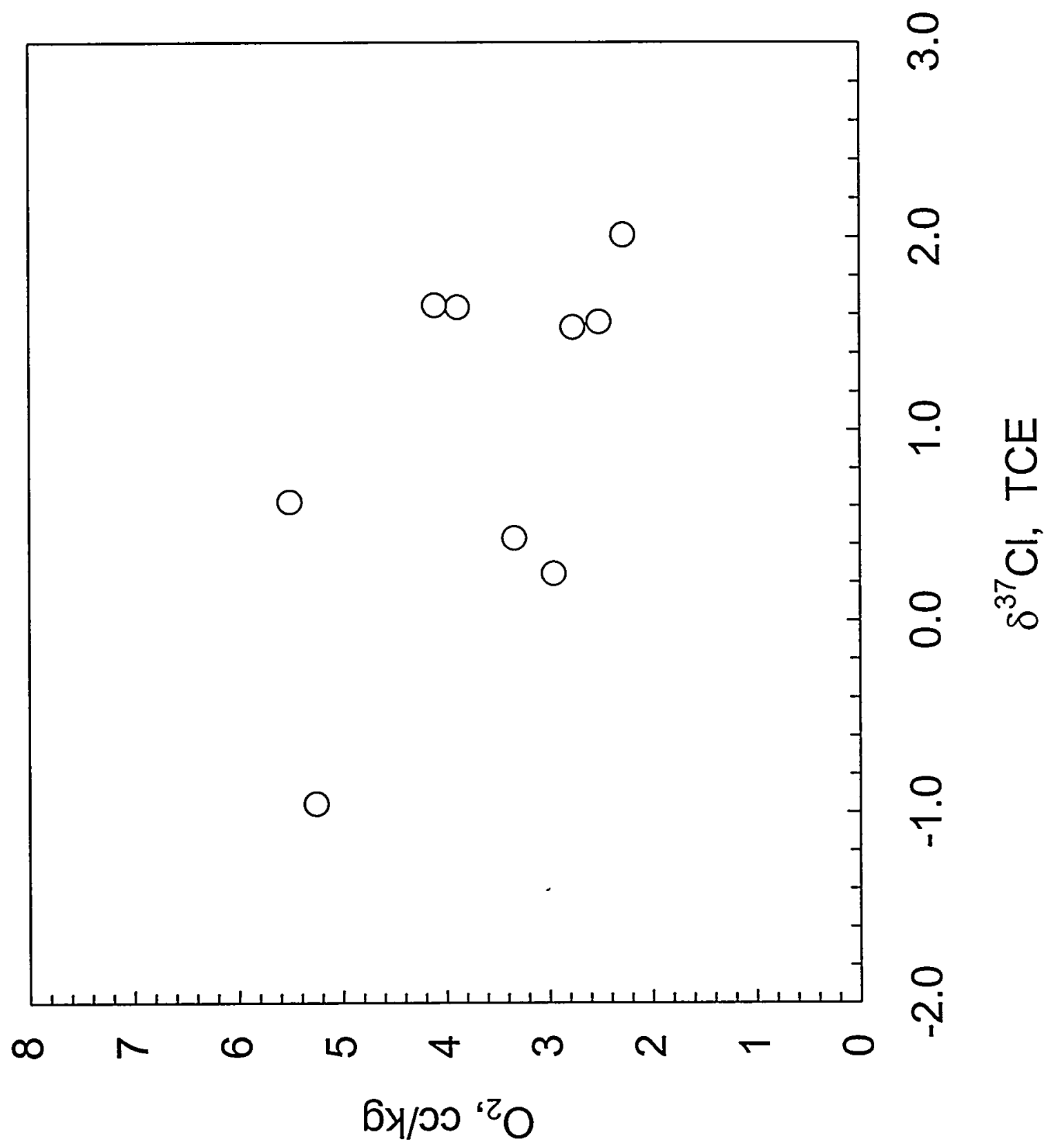


Figure 14. The relationship of normalized $\delta^{37} \mathrm{Cl}$ of TCE to normalized TCE concentrations

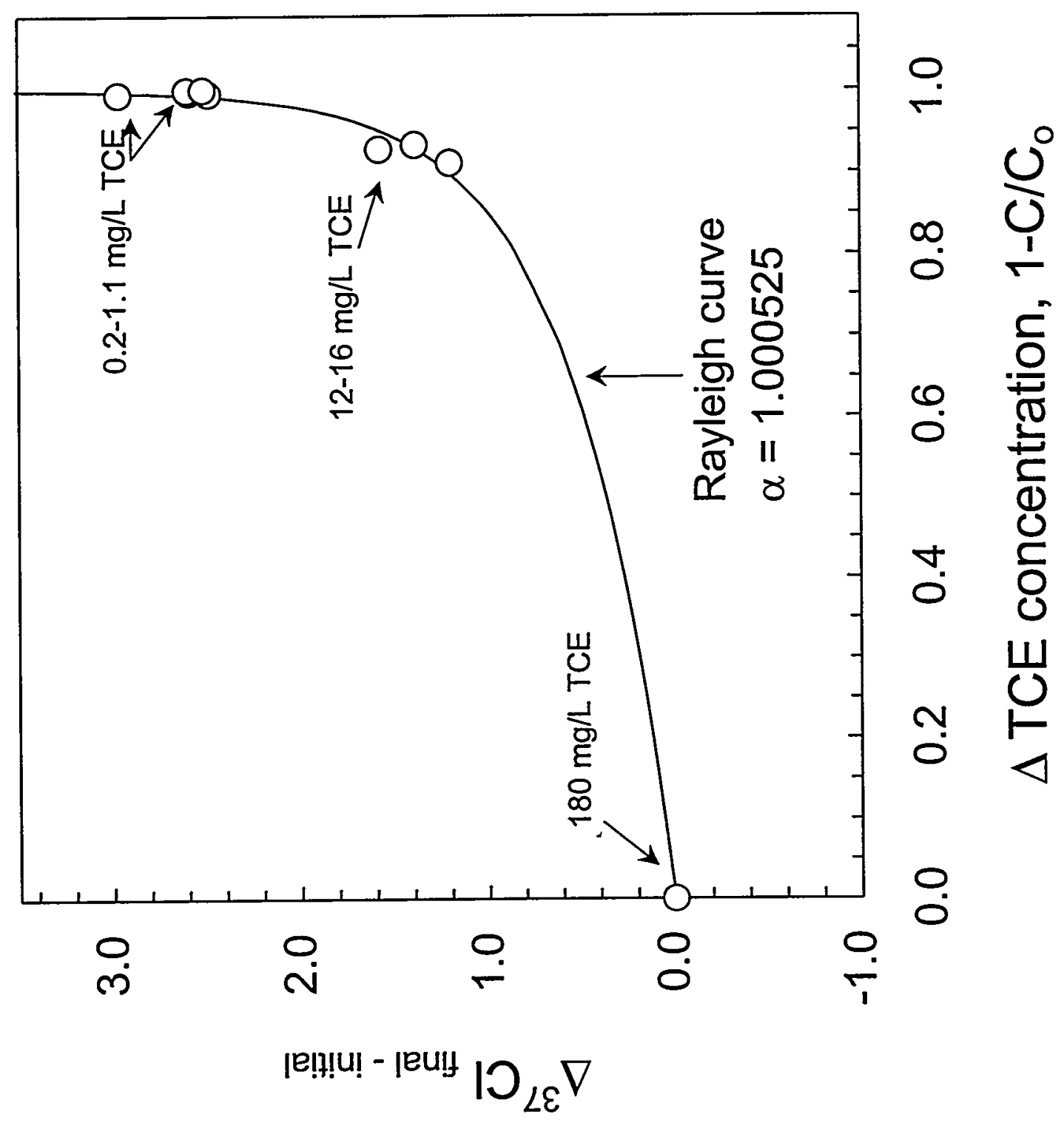


Figure 15. The relationship of $8^{37} \mathrm{Cl}$ of $\mathrm{TCE}$ to $8^{37} \mathrm{Cl}$ of dissolved inorganic chloride

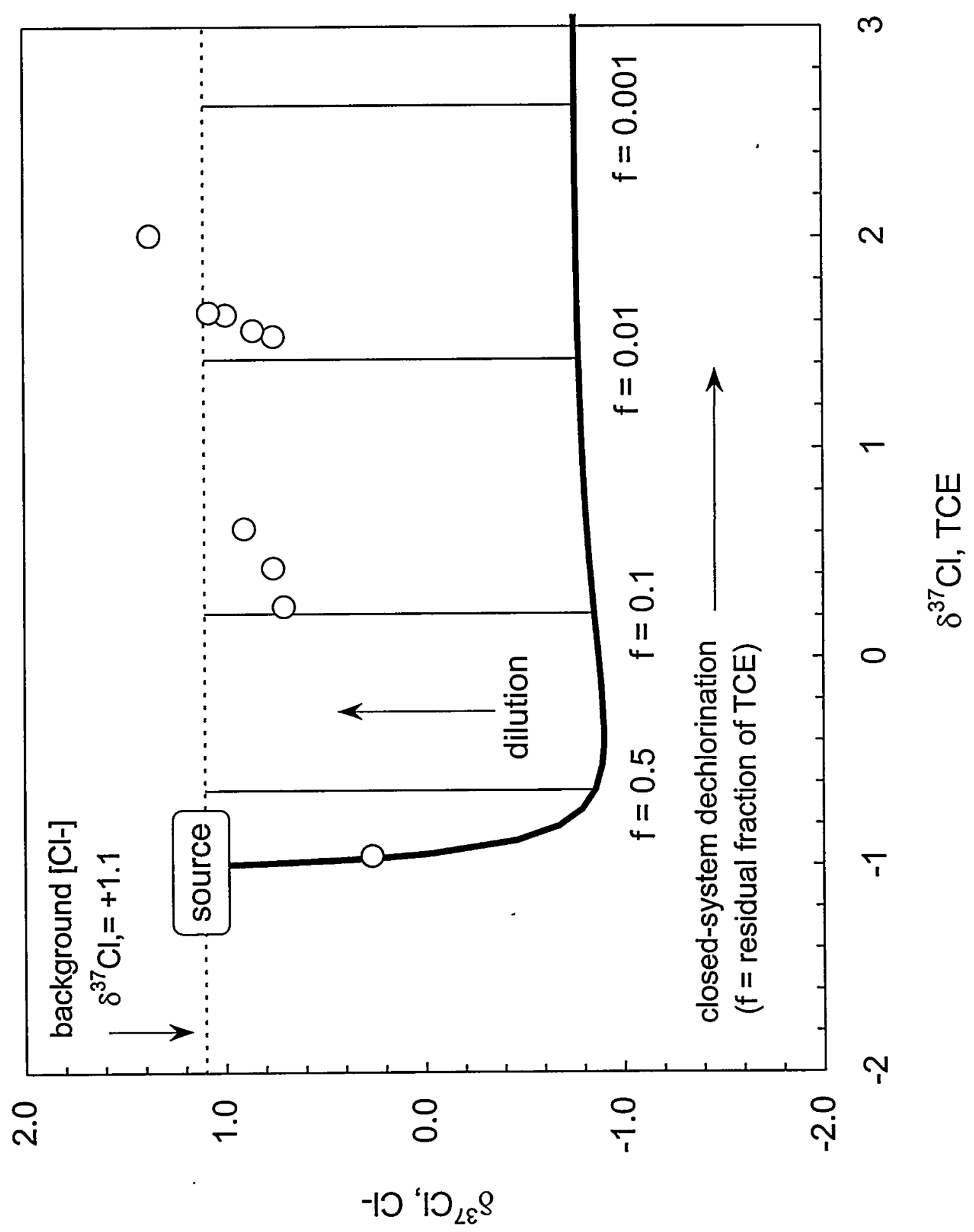




\subsubsection{Methanogenic Processes}

The current study did not indicate the presence of methane in any PGDP groundwater samples; the detection limit was $0.002 \mathrm{mg} / \mathrm{L}$ (Appendix A). The absence of methane appears to indicate a general lack of methanogenic microbial activity within the plumes. Methane is an indicator of methanogenic microbial activity, although it may also be consumed by methanotrophic microorganisms. Chapelle et al. (1995) point out methane may be transported away from areas of production by groundwater flow. However, methane was not detected in any downgradient wells within the plumes. The next dominant electron acceptor reaction is sulfate reduction.

\subsubsection{Sulfate Reduction}

Sulfate reduction identification can be less clear than a methanogenic evaluation due to the possible precipitation of sulfides. In the sulfate reduction reaction, sulfate is consumed and hydrogen sulfide produced. Along the flow path of the Northwest Plume, sulfate concentrations are unchanged (Table 7 and Figure 16). Similarly, the hydrogen sulfide data indicates a lack of accumulation along the groundwater flow path for the Northwest Plume (Table 7 and Figure 16).

As can be seen in Figure 17, the sulfate data for the Northeast Plume is less definitive. Sulfate appears to be slightly elevated in both plumes as compared to the background wells MW103 and MW194 (Figure 18). Elevated sulfate exists at MW108 and MW255 in the Northeast Plume as compared with MW155 located at the source. Figure 17 and Table 8 indicate sulfate levels decline along the flowpath. However, hydrogen sulfide data is not supportive of the sulfate results and does not indicate an increasing concentration trend with distance (Tables 7, 8, and Figure 18). However, as pointed out by Chapelle et al. (1995) patterns of electron acceptor consumption and production are not always definitive. Plummer et al. (1990) report sulfate replenishment in some aquifer systems from mineral sources and Chapelle and Lovley (1992) and McMahon et al. (1992) report similar occurrences from confining bed pore water. Furthermore, dissolved sulfides readily precipitate from solution in the presence of metals (Chapelle et al., 1995). For this reason, Chapelle et al. (1995) rely on hydrogen, an intermediate anaerobic microbial metabolic product. Nitrate reduction is a possible mechanism for consideration at the PGDP site based on the hydrogen results.

\subsubsection{Nitrate Reduction}

Nitrate levels for both groundwater plumes appear elevated as compared with the background wells MW103 and MW194. Nitrate reduction is characterized by a decline in nitrate-nitrogen along the flow-path of a plume with concomitant increase in dissolved nitrogen levels. The data for the Northeast Plume clearly indicates a lack of nitrate decline (Table 8 and Figure 19). Nitrogen levels in the Northeast Plume are consistently around $20 \mathrm{mg} / \mathrm{L}$ with no increasing or decreasing trends evident. Well MW100 indicates an elevated level of nitrate-nitrogen as compared to upgradient wells. However, agricultural fields, typically of corn, lie directly upgradient of MW100. The application of nitrogen fertilizers is suspected to be the source of the nitrate in the well. In the Northwest Plume, nitrate levels downgradient of MW262 appear to decline with distance. However, MW155 located at the presumed source of the plume has relatively low levels of nitrate. The decline of nitrate levels as an indicator of nitrate reduction are not consistent with the nitrogen and hydrogen data (Table 7). Richards (personnel communication, 1997) indicated a known release of nitric acid occurred in a field to the east of the C-404 landfill, which is upgradient of MW262 and downgradient of MW155. Routine monitoring well data from UCRS wells in this area seem to substantiate the nitric acid release. Nitrate concentrations in MWs 170, 171, and 172 have been reported in the 100's of ppm. 
Table 6. Comparison of site specific geochemical parameters against a biodegradation screening protocol developed by Wiedemeier et al. (1996)

\begin{tabular}{|c|c|c|}
\hline Analyte & $\begin{array}{l}\text { Concentration Range in Most } \\
\text { Contaminated Zone }\end{array}$ & Points Awarded \\
\hline D.O. & 1.0 to $7.9 \mathrm{mg} / \mathrm{L}$ & -3 \\
\hline Nitrate & 7.5 to $50 \mathrm{mg} / \mathrm{L}$ & 0 \\
\hline Iron (II) & $<0.1$ to $0.2 \mathrm{mg} / \mathrm{L}$ & 0 \\
\hline Sulfate & 10 to $30 \mathrm{mg} / \mathrm{L}$ & 0 \\
\hline Sulfide & $<0.01 \mathrm{mg} / \mathrm{L}$ & 0 \\
\hline Methane & $<0.002$ & 0 \\
\hline Eh & +120 to +460 & 0 \\
\hline DOC & 1 to $2 \mathrm{mg} / \mathrm{L}$ & 0 \\
\hline Temperature & 15.0 to $16.7^{\circ} \mathrm{C}$ & 0 \\
\hline Carbon Dioxide & ( $<2 X$ background $)$ & 0 \\
\hline Alkalinity & $99-223 \mathrm{mg} / \mathrm{L}(<2 \mathrm{X}$ background & 0 \\
\hline Chloride & $25-90 \mathrm{mg} / \mathrm{L}$ (2X background) & 2 \\
\hline Hydrogen & $<0.22 \mathrm{nM}$ & 0 \\
\hline BTEX & ND & 0 \\
\hline 1,1-DCE & ND & 0 \\
\hline cis-1,2-DCE & $<0.001$ to $0.057 \mathrm{mg} / \mathrm{L}$ & 0 \\
\hline $\mathrm{VC}$ & $<0.003 \mathrm{mg} / \mathrm{L}$ & 0 \\
\hline Ethene/Ethane & $<0.03 \mathrm{mg} / \mathrm{L}$ & 0 \\
\hline \multirow[t]{2}{*}{ Chloroethane } & ND & 0 \\
\hline & Total Points Awarded & -1 \\
\hline
\end{tabular}




\section{Northwest Plume}

\section{North West Plume}
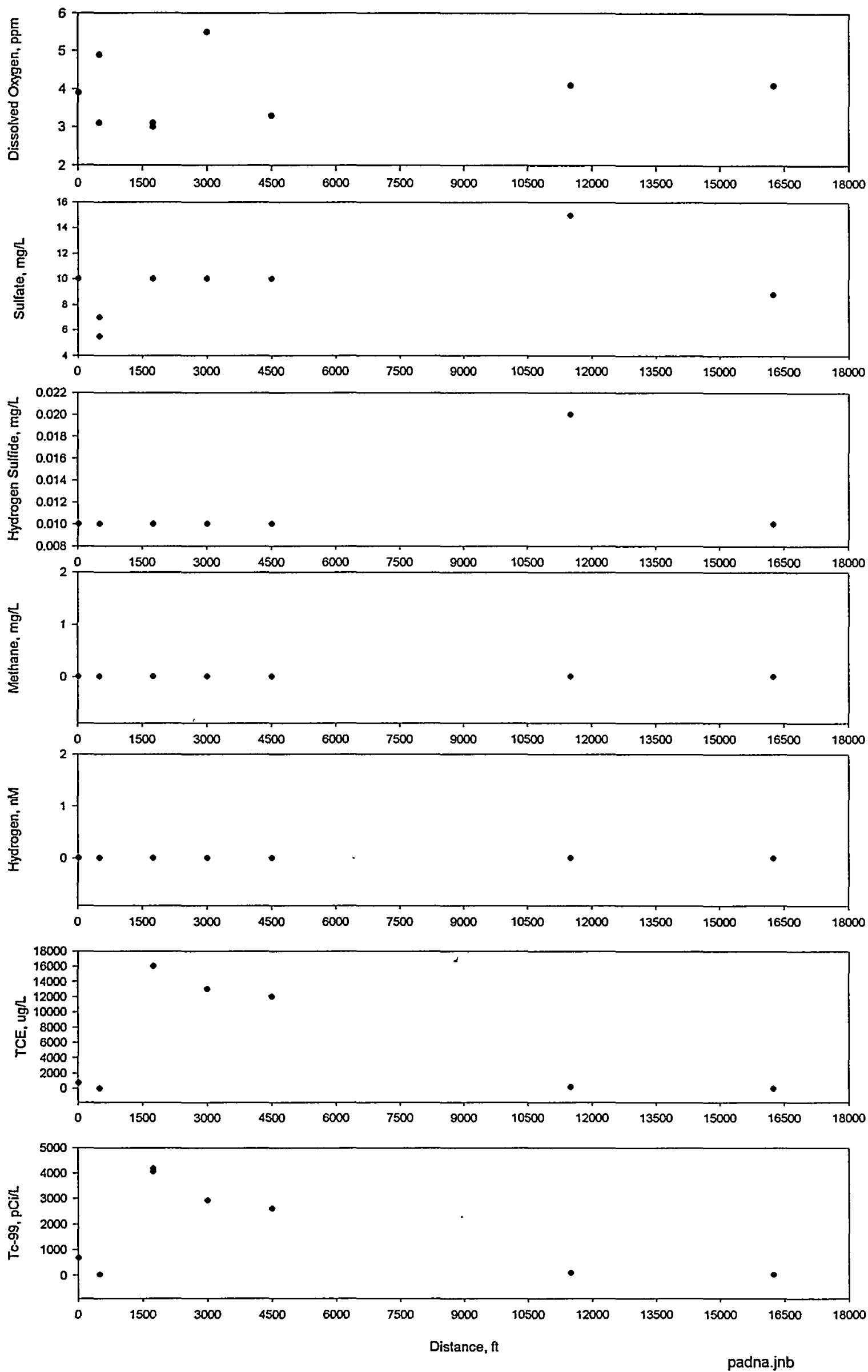
Figure 17. Comparison of redox sensitive parameters along the groundwater flowpath for the Northeast Plume North East Plume
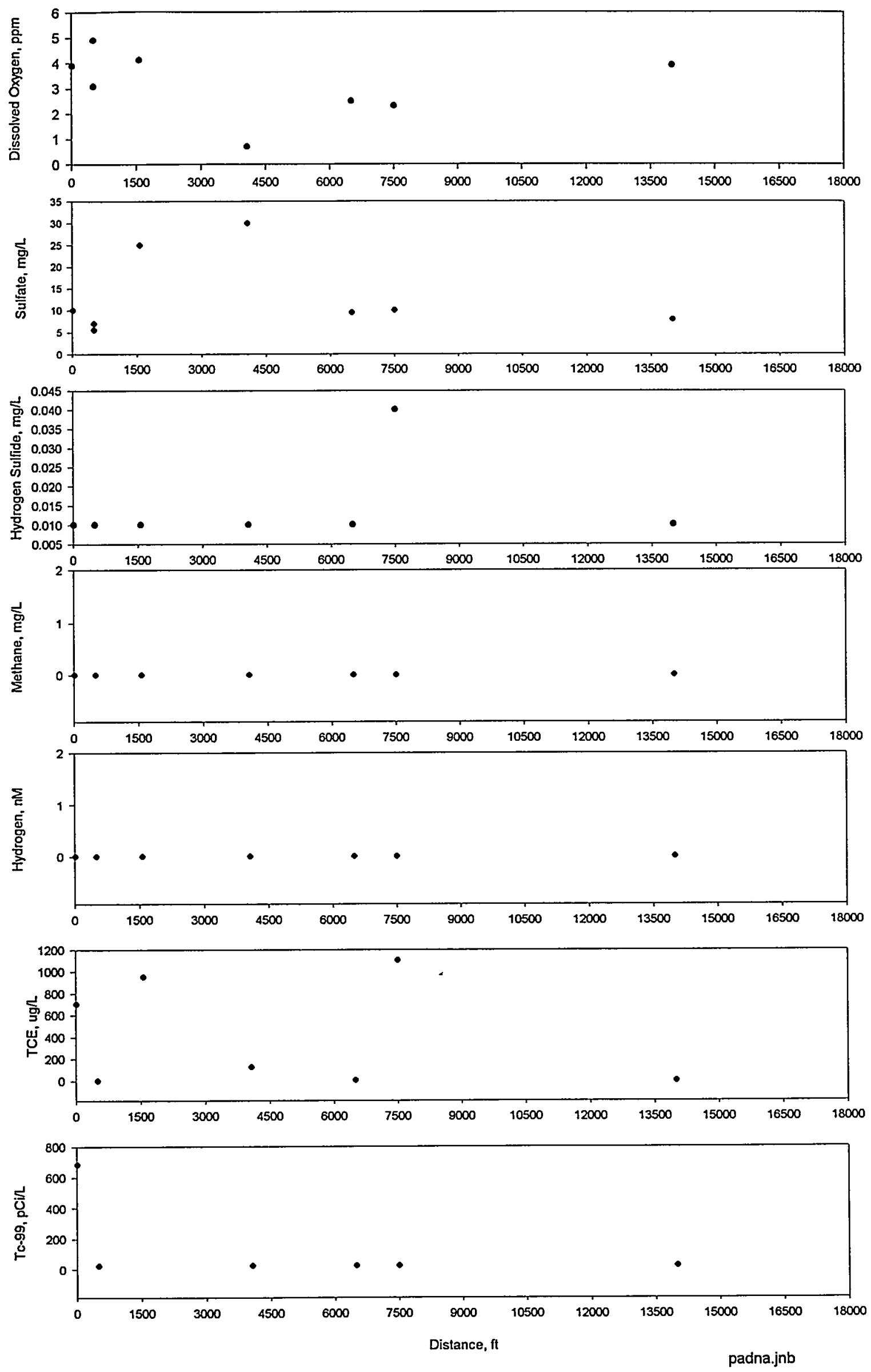

39 
Figure 18. Plan view representation of sulfate levels within the RGA

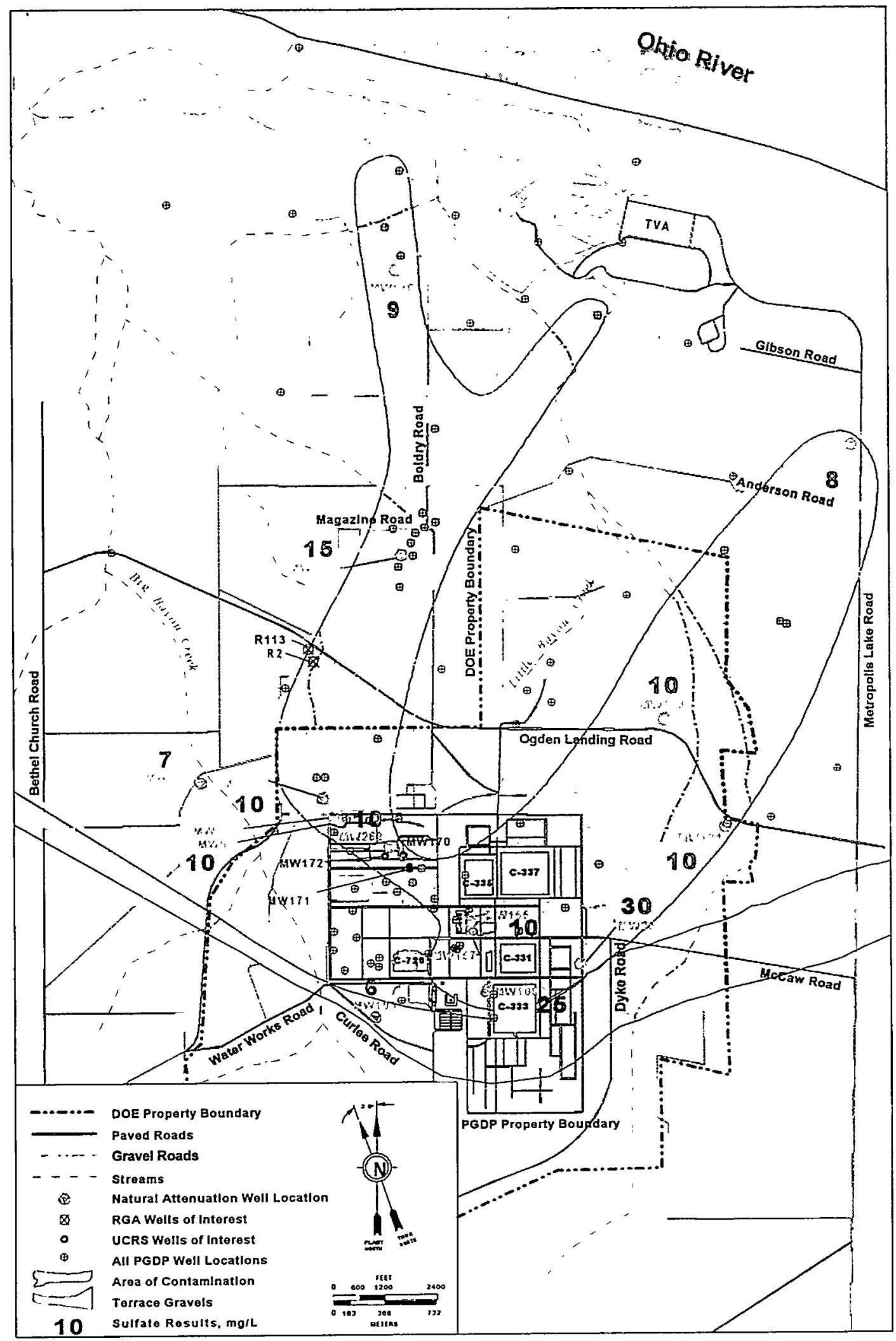

contam 
Table 7. Concentrations of redox sensitive parameters in the Northwest Plume

\begin{tabular}{|l|l|l|l|l|l|l|l|l|}
\hline Well & $\begin{array}{c}\mathrm{H}_{2} \\
\mathrm{nM}\end{array}$ & $\begin{array}{c}\mathrm{SO}_{4} \\
\mathrm{mg} / \mathrm{L}\end{array}$ & $\begin{array}{c}\mathrm{H}_{2} \mathrm{~S} \\
\mathrm{mg} / \mathrm{L}\end{array}$ & $\begin{array}{c}\mathrm{CH}_{4} \\
\mathrm{mg} / \mathrm{L}\end{array}$ & $\begin{array}{c}\mathrm{Fe}^{2+} \\
\mathrm{mg} / \mathrm{L}\end{array}$ & $\begin{array}{c}\mathrm{NO}_{3} \\
\mathrm{mg} / \mathrm{L}\end{array}$ & $\begin{array}{c}\text { D.O. } \\
\mathrm{mg} / \mathrm{L}\end{array}$ & $\begin{array}{c}\text { Distance from } \\
\text { Source (ft) }\end{array}$ \\
\hline 155 & $<0.22$ & 10 & $<0.01$ & $<0.002$ & $<0.1$ & 9.0 & 5.6 & 0 \\
\hline 262 & $<0.22$ & 10 & $<0.01$ & $<0.002$ & $<0.1$ & 50 & 4.3 & 1750 \\
\hline 66 & $<0.22$ & 10 & $<0.01$ & $<0.002$ & $\mathrm{NA}$ & 35 & 7.9 & 3000 \\
\hline 248 & $<0.22$ & 10 & $<0.01$ & $<0.002$ & $<0.1$ & 30 & 4.7 & 4500 \\
\hline 233 & $<0.22$ & 15 & 0.02 & $<0.002$ & 0.1 & 7.5 & 5.9 & 11,500 \\
\hline 146 & $<0.22$ & 8.8 & $<0.01$ & $<0.002$ & $<0.1$ & 15 & 5.9 & 16,250 \\
\hline
\end{tabular}

NA - not analyzed

Table 8. Concentrations of redox sensitive parameters in the Northeast Plume

\begin{tabular}{|l|l|l|l|l|l|l|l|l|}
\hline Well & $\begin{array}{c}\mathrm{H}_{2} \\
\mathrm{nmol}\end{array}$ & $\begin{array}{c}\mathrm{SO}_{4} \\
\mathrm{mg} / \mathrm{L}\end{array}$ & $\begin{array}{c}\mathrm{H}_{2} \mathrm{~S} \\
\mathrm{mg} / \mathrm{L}\end{array}$ & $\begin{array}{c}\mathrm{CH}_{4} \\
\mathrm{mg} / \mathrm{L}\end{array}$ & $\begin{array}{c}\mathrm{Fe}^{2+} \\
\mathrm{mg} / \mathrm{L}\end{array}$ & $\begin{array}{c}\mathrm{NO}_{3} \\
\mathrm{mg} / \mathrm{L}\end{array}$ & $\begin{array}{c}\text { D.O. } \\
\mathrm{mg} / \mathrm{L}\end{array}$ & $\begin{array}{c}\text { Distance from } \\
\text { Source (ft) }\end{array}$ \\
\hline 155 & $<0.22$ & 10 & $<0.01$ & $<0.002$ & $<0.1$ & 9.0 & 5.6 & 0 \\
\hline 108 & $<0.22$ & 25 & $<0.01$ & $<0.002$ & 0.1 & 9.3 & 4.0 & 1575 \\
\hline 255 & $<0.22$ & 30 & $<0.01$ & $<0.002$ & $<0.1$ & 6.8 & 1.0 & 4075 \\
\hline 124 & $<0.22$ & 10 & 0.04 & $<0.002$ & $<0.1$ & 6.1 & 3.3 & 6500 \\
\hline 193 & $<0.22$ & 9.5 & $<0.01$ & $<0.002$ & $<0.1$ & 0.7 & 3.6 & 7500 \\
\hline 100 & $<0.22$ & 7.9 & $<0.01$ & $<0.002$ & $<0.1$ & 20 & 5.6 & 14,400 \\
\hline
\end{tabular}

$\mathrm{NA}$ - not analyzed 
Figure 19. Plan view representation of nitrate levels within the RGA

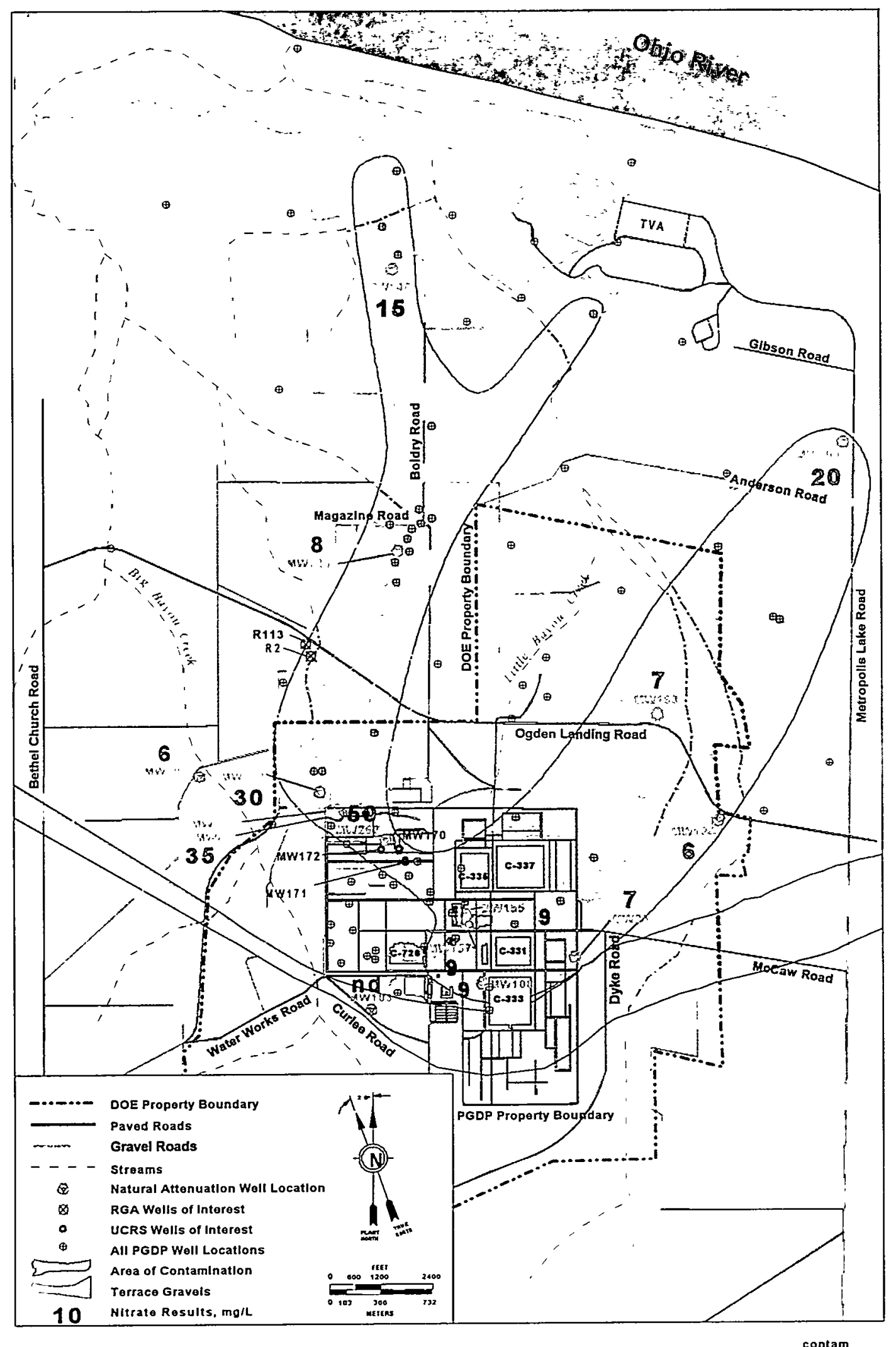


Additional evidence for the lack of denitrification is the comparison of dissolved gases argon and nitrogen in groundwater (Figure 20). If significant amounts of denitrification are occurring the data points would fall far to the right of the temperature indicator field. Figure 20 also suggests recharged water had a temperature of approximately $10^{\circ} \mathrm{C}$ and may have incorporated excess air in the process. Thus, nitrate reduction does not appear to be supported by the available data for PGDP. The final terminal electron acceptor reaction possible for the reduction of TCE is iron reduction.

\subsubsection{Iron reduction}

Total iron and ferrous iron measurements were made in the field with Hach colorimetric methods (Hach, 1982). Ferric iron was calculated by subtracting ferrous iron from total iron values. The resulting data indicates the dominant iron species to be ferric. It seems reasonable that the dominant form of iron is ferric with the likely species being $\mathrm{Fe}(\mathrm{OH})_{3}$. Geochemical modeling analysis using data from the Northwest Plume resulted in ferric iron being identified as the dominant form at PGDP (Clausen et al., 1993). Lovley and Phillips (1986) have documented that ferric iron can be bioavailable and that ferric iron reduction can be an important mechanism for organic matter decomposition. However, as reported by Lovley et al. (1989), the iron reduction reaction results in accumulation of ferrous iron which is not evident in either plume. In comparison, $\mathrm{Eh} / \mathrm{pH}$ measurements plotted on a pH-potential diagram for iron suggest the dominant iron species to be ferrous. Previous work by Clausen et al. (1995a) indicates ferric iron is the stable species. However, as mentioned in Section 1.6, Eh measurements have frequently been questioned in the literature due to the non-specificity of the redox couple being measured. The current Eh data was not corrected for temperature, which would result in a positive shift from the ferrous to ferric iron field (Figure 21). Ferrous iron could react with sulfides and be precipitated out of solution, but the data generally indicate negligible sulfide concentrations in the groundwater (Tables 8 and 9). Thus, all of the available evidence suggests iron reduction is not an active mechanism for the reduction of TCE. Lovley and Phillips (1986) report ferric iron must be in a form bioavailable for the reaction to occur. The iron reduction reaction as well as the other reductive processes produce chloride. Chloride is produced through the dechlorination of organic chlorinated compounds.

\subsubsection{Chloride Production}

Another line of evidence for the intrinsic bioremediation of TCE is increasing chloride concentrations along the flow path of the plume. For every mole of TCE completely dehalogenated three moles of chloride are produced. Figure 22 appears to indicate a possible increase in chloride levels along the flow path of the plumes. More evident, is that chloride levels in both plumes are elevated in comparison with the two background wells MW103 and MW194 (3 and $20 \mathrm{mg} / \mathrm{L}$ chloride, respectively). Roughly, chloride levels in both plumes are three times the background levels, which is consistent with the stoichiometry for TCE reductive dechlorination. However, an analytical analysis indicates the given concentration levels of TCE in the plume, coupled with a flux rate calculated in Section 5.7.1, would yield $10 \mathrm{mg} / \mathrm{L}$ chloride produced. Given background chloride levels range from 3 to $20 \mathrm{mg} / \mathrm{L}$, the production of chloride via reductive dechlorination is likely to be masked and indiscernible from natural or other anthropogenic sources of chloride. Figure 23 shows the relationship of chloride to TCE and the expected trends for dilution and dechlorination of TCE. The increasing chloride levels with declining TCE supports both dilution and intrinsic bioremediation of TCE. However, the previous discussion of electron acceptors eliminates reductive degradation processes as a mechanism for the dechlorination of TCE and production of chloride. Thus, the production of chloride could possibly be the result of an aerobic cometabolic process. 
Figure 20. The relationship of argon to nitrogen

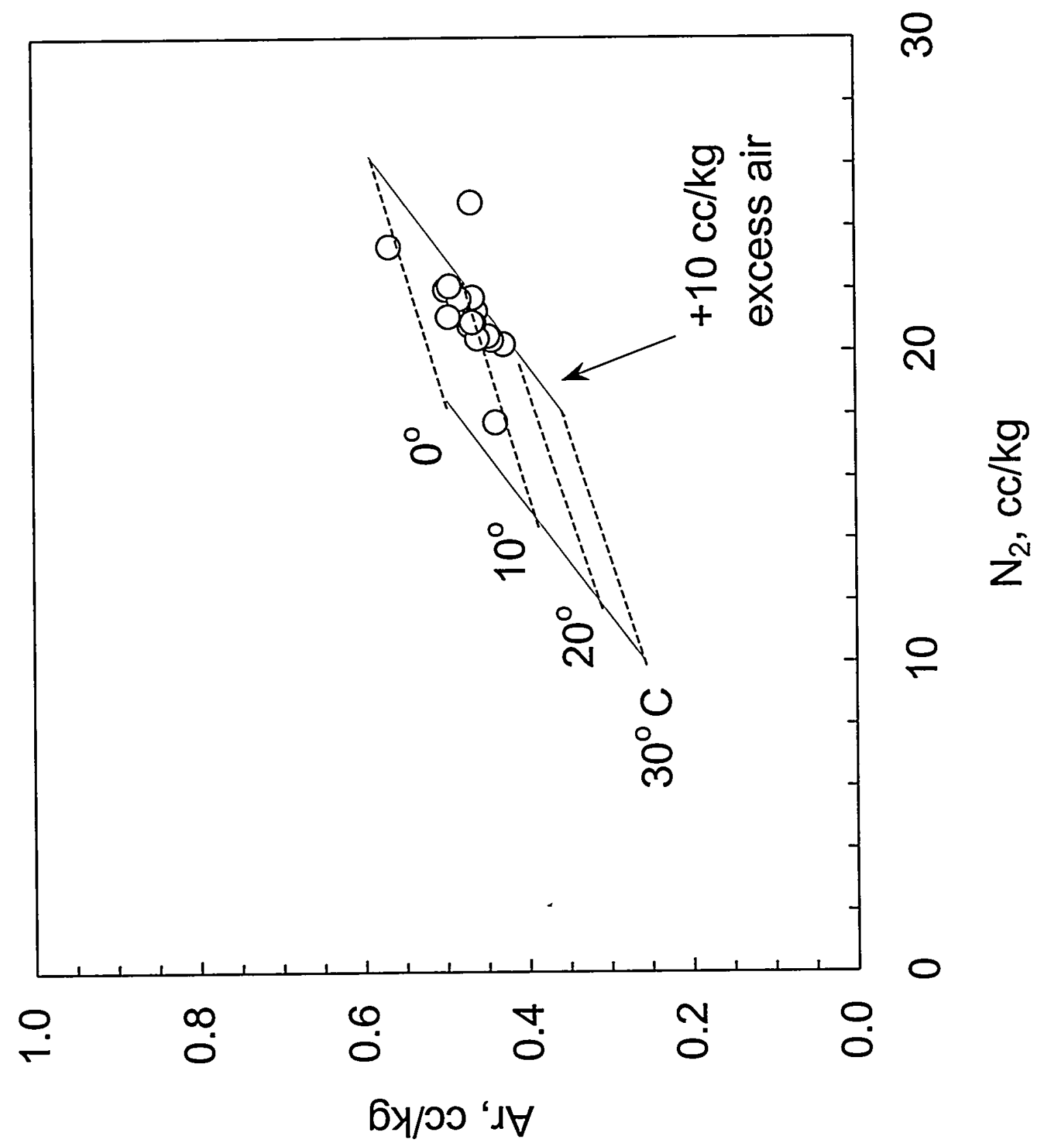


Figure 21. Potential-pH diagram for iron

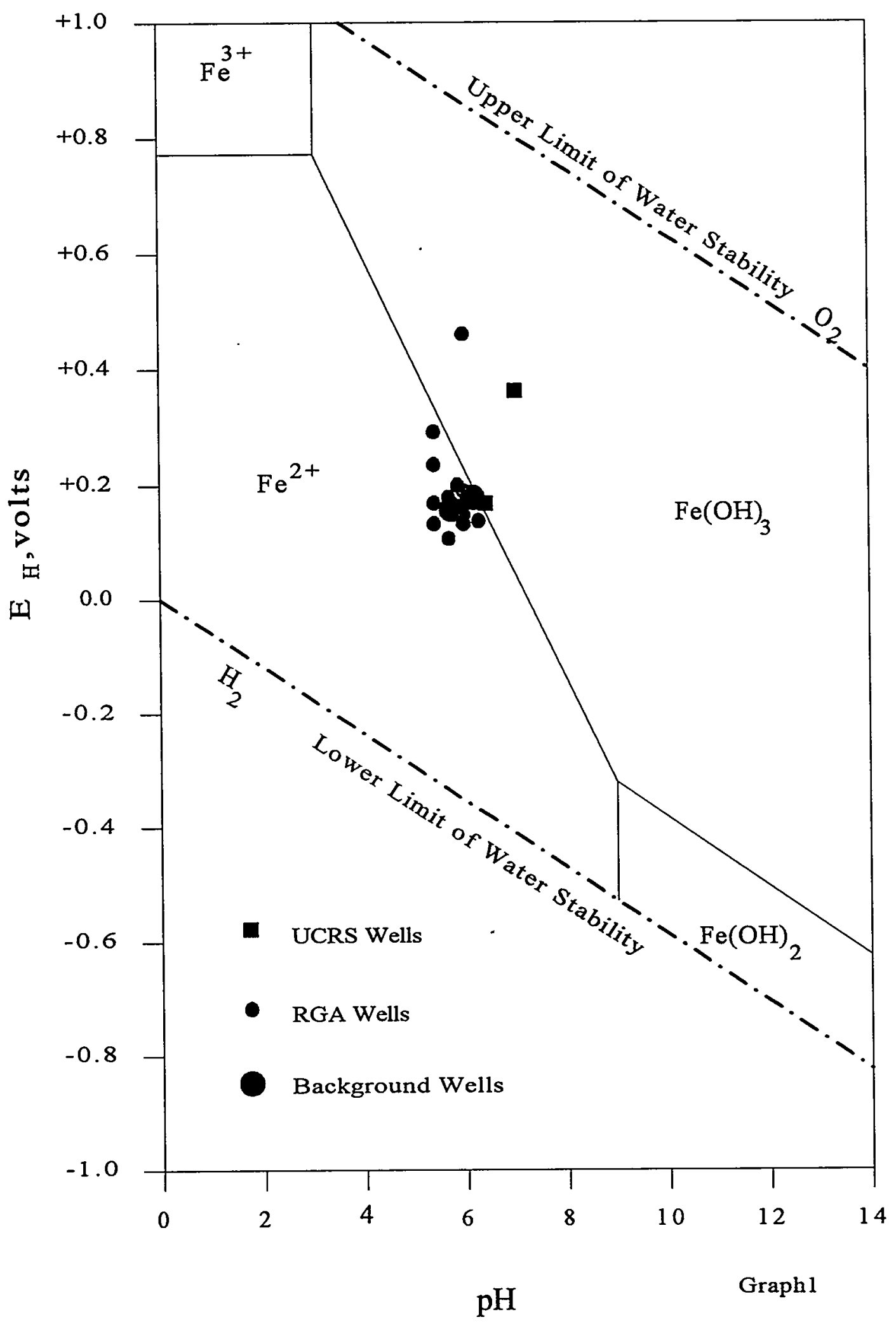


Figure 22. Plan view representation of chloride levels within the RGA

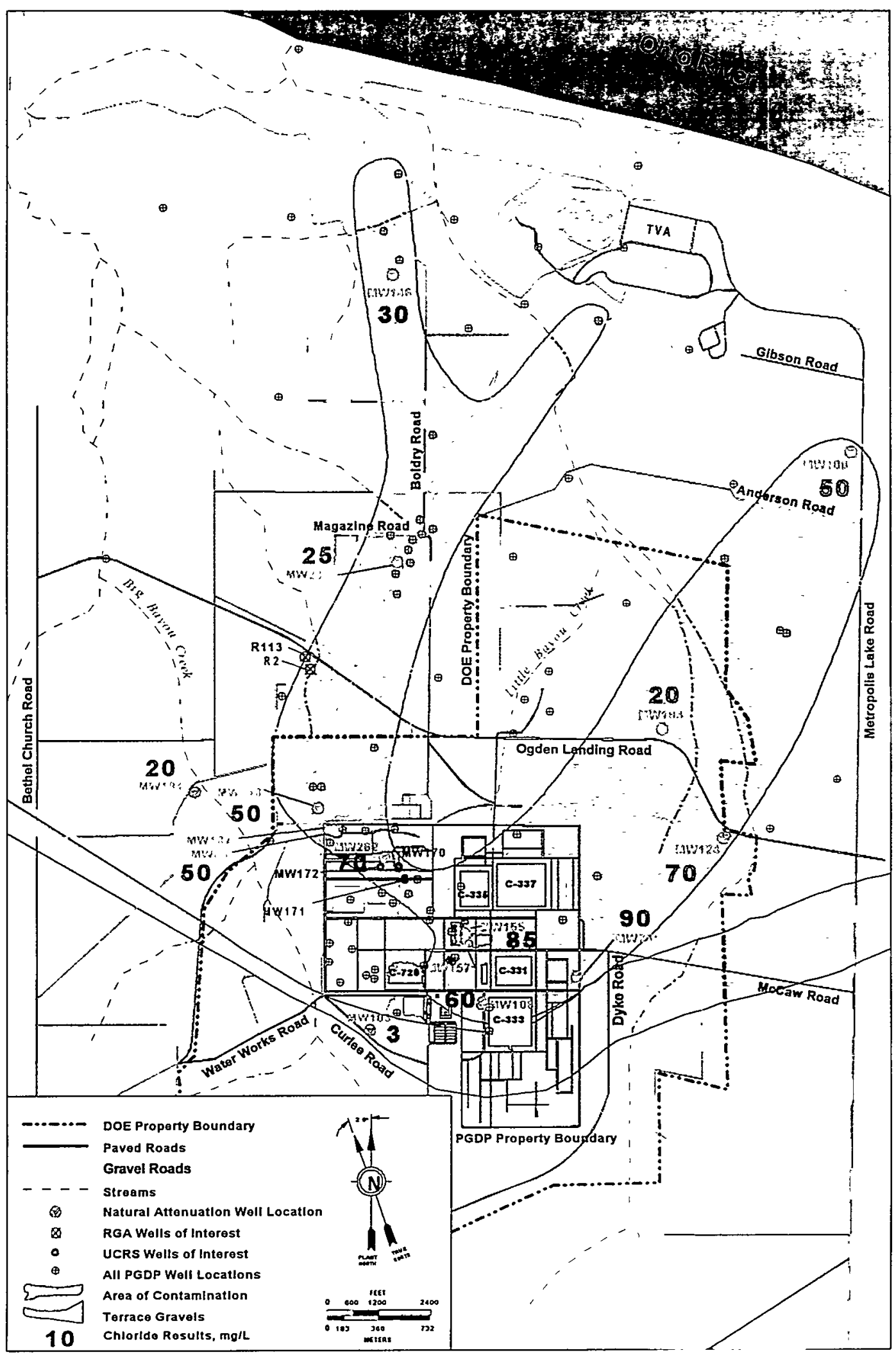

contam 
Figure 23. The relationship of chloride to TCE

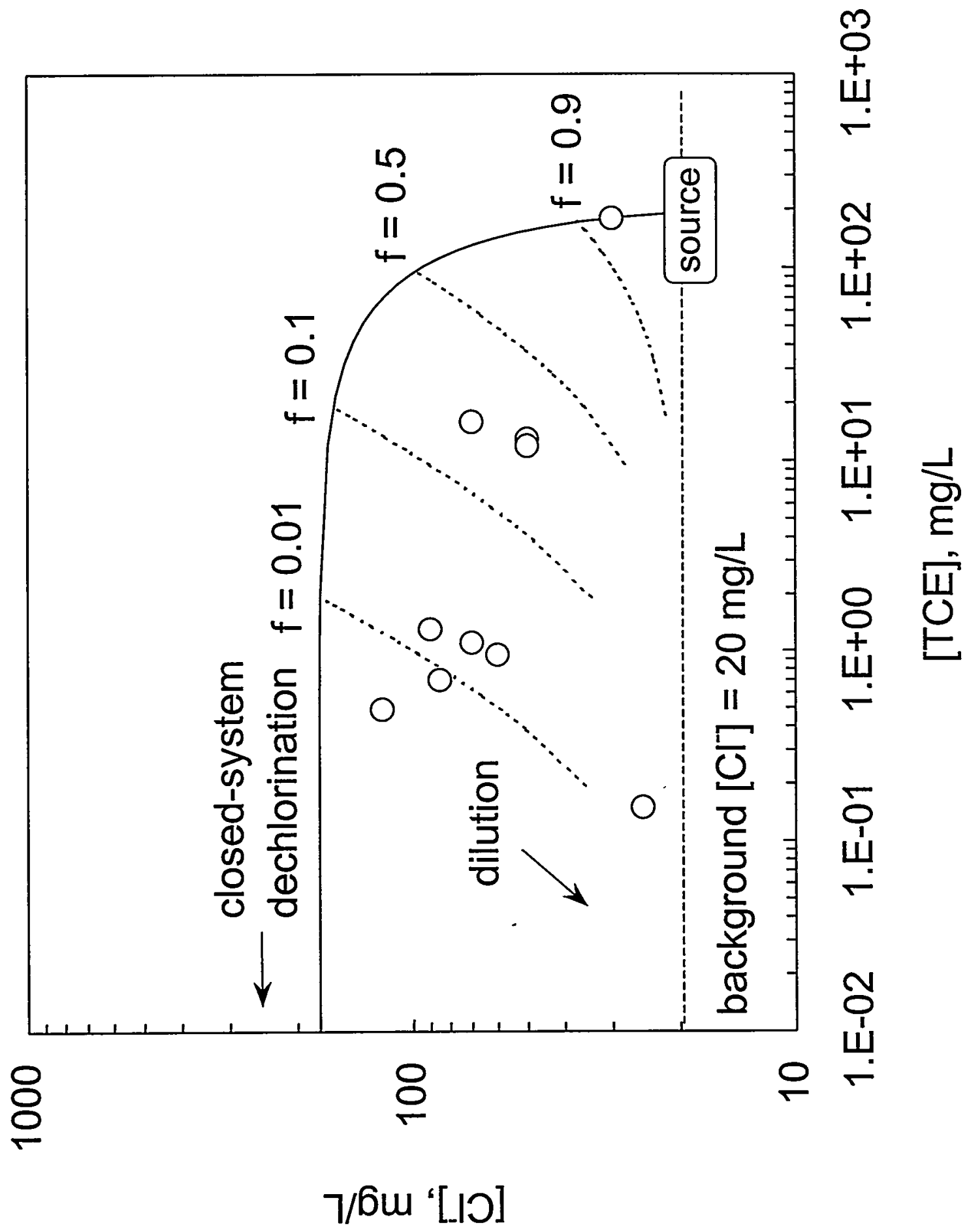


However, no compelling geochemical evidence supports the reductive dechlorination of TCE via microbial processes due to the absence of an energy source such as organic matter, methane, toluene, etc. Even if these energy sources are available, less than one percent of the energy flow is directed to cometabolic degradation of TCE (Phelps, personal communication, 1997). Several possible hypothesis for the incongruity of data are presented in Section 6.

\subsection{RADIOCHEMISTRY}

Unlike the previous discussion of TCE being amenable to biological dechlorination, no known biological processes can be found in the literature for the destruction or removal of ${ }^{99} \mathrm{Tc}$ from groundwater. Since the reactivity of ${ }^{99} \mathrm{Tc}$ is redox sensitive, an attempt was made to measure $\mathrm{Eh}$ in this study. The data from this study was plotted on a potential-pH diagram (Figure 24) modified from Allard et al. (1979) and Paquette et al. (1980). All of the samples fall in the region of $\mathrm{TcO}_{4}^{-}$which is in the Tc (VII) redox state and is referred to as the pertechnetate anion. This result is consistent with work by Gu et al. (1994) Clausen et al. (1995b), and Gu and Dowlen (1996) specific to the PGDP site, indicating the likely form of ${ }^{99} \mathrm{TC}$ is as the pertechnetate anion. Additionally, ${ }^{99} \mathrm{Tc}$ is present off-site as far as 3.1 miles from the source area within the Northwest Plume indicating ${ }^{99} \mathrm{Tc}$ is in a very mobile state. This was confirmed by the work of $\mathrm{Gu}$ and Dowlen (1996) which found no measurable sorption of ${ }^{99} \mathrm{Tc}$ onto RGA lithologic material. Thus, there is little evidence for the reduction of ${ }^{99} \mathrm{Tc}$ levels through precipitation or sorption. The long radioactive decay process for ${ }^{99} \mathrm{Tc}$, as discussed in Section 1.6, precludes this mechanism as an important means for the reduction of ${ }^{99} \mathrm{Tc}$. Therefore, through a process of elimination the dominant mechanism for NA of ${ }^{99} \mathrm{Tc}$ within the RGA is through advection, dispersion, dilution, and possibly diffusion. EPA (1997) suggest the presence of an unreactive co-contaminant, such as ${ }^{99} \mathrm{Tc}$, may be used to evaluate the rate of biodegradation.

\subsection{QUANTIFICATION OF NATURAL ATTENUATION}

As pointed out by (Jacobs, 1997), the presence of ${ }^{99} \mathrm{Tc}$, an unreactive contaminant, with TCE potentially could be used to evaluate TCE biodegradation rates. However, the utilization of this approach requires no other attenuating processes to be active within the aquifer, except for biodegradation. The potential for absorption of TCE onto the aquifer matrix raises the question of the appropriateness of this analytical analysis method for PGDP. However, another approach is possible looking at the flux rates through a given cross-sectional area, as well as simple geochemical modeling.

\subsubsection{Northwest Plume}

Clausen et al. (1995a) calculated the annual mass flux of TCE through a cross-sectional area of the Northwest Plume at the DOE property boundary yielding a value ranging from 18 to $32 \mathrm{~kg} / \mathrm{year}$. This calculation is all inclusive for the NA mechanisms, and thus includes biological as well as non-biological processes. The DOE property boundary is approximately $6000 \mathrm{ft}$ from the source area, $\mathrm{C}-400$, following the centerline of the plume. The calculation was based on the equation:

$$
Q=n_{i} A
$$

$$
\text { where } \begin{aligned}
Q & =\text { volume of contaminated water, } \\
\mathbf{n}_{\mathrm{i}} & =\text { intrinsic permeability } \\
\mathrm{A} & =\text { area of contaminated water. }
\end{aligned}
$$


Figure 24. Potential-pH stability diagram for ${ }^{99} \mathrm{Tc}$

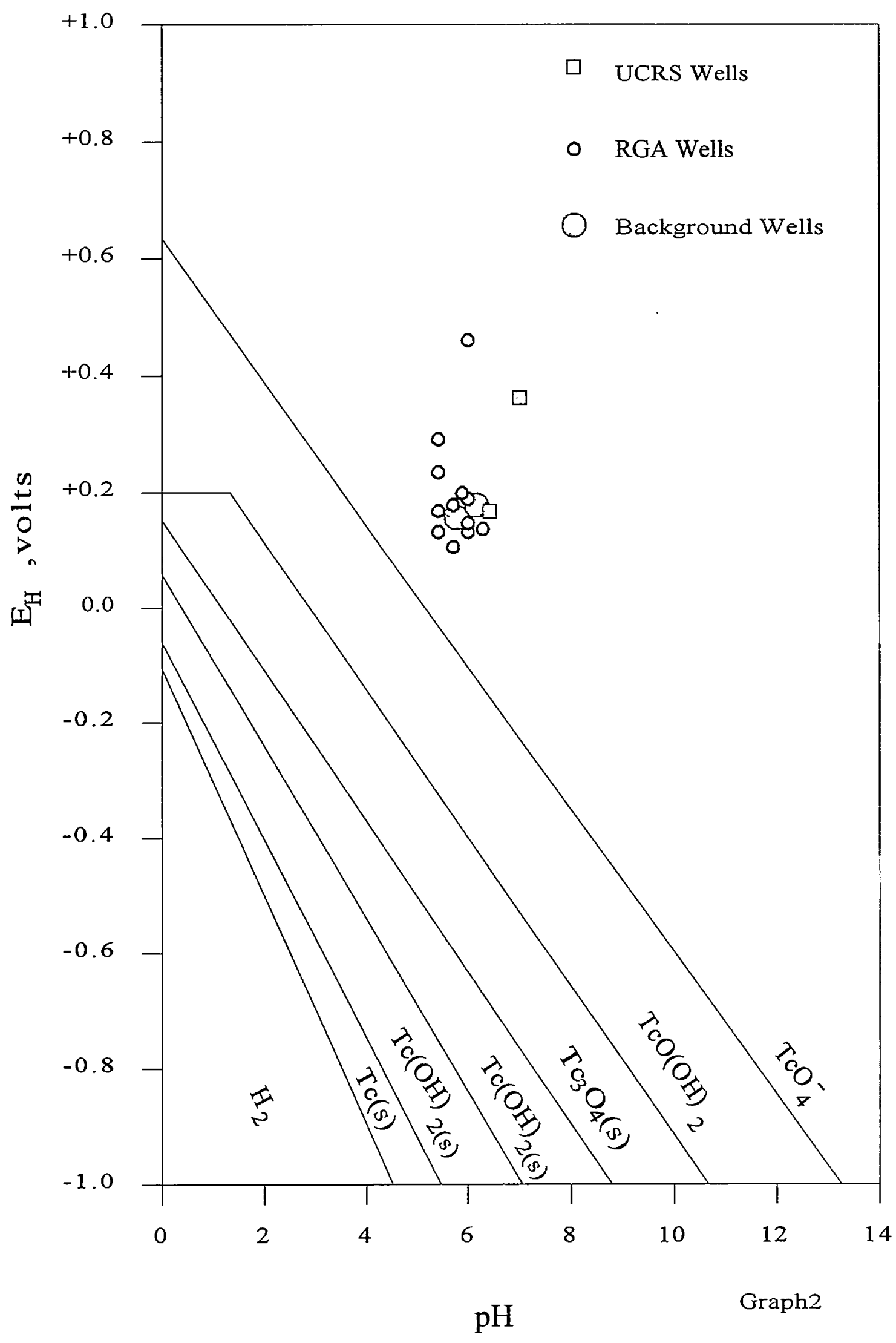


Integrating the concentrations within the cross-sectional area and knowing the groundwater flow velocity allows for a calculation of flux. In all of the flux calculations a porosity of 0.25 and a flow rate of $1.3 \mathrm{ft} /$ day was assumed (McConnell, 1992 and Clausen et al., 1995a). Similar calculations can be performed for a crosssectional area of the Northwest Plume at the plant fence boundary, near Ogden Landing Road, and the northern extraction well field, at distances of 3000,8800 , and 11,500 from the source zone, respectively (Table 9).

Table 9. Comparison of flux rates within the Northwest Plume

\begin{tabular}{|l|l|l|l|l|}
\hline \multicolumn{1}{|c|}{ Location } & $\begin{array}{c}\text { Flux Rate TCE } \\
(\mathrm{kg} / \mathrm{yr})\end{array}$ & $\begin{array}{c}\text { Flux Rate } \\
(\mathrm{pCi} / \mathrm{yr})\end{array}$ & $\begin{array}{c}\text { Flux Rate } \\
{ }^{99} \mathrm{Tc}(\mathrm{ug} / \mathrm{yr})\end{array}$ & $\begin{array}{c}\text { Distance from } \\
\text { Source (ft) }\end{array}$ \\
\hline Plant Perimeter Fence & 16 & 0.4 & 80 & 3000 \\
\hline $\begin{array}{l}\text { DOE Property } \\
\text { Boundary }\end{array}$ & 25 & 0.5 & 100 & 7000 \\
\hline Ogden Landing Road & 2.4 & 0.4 & 80 & 8800 \\
\hline $\begin{array}{l}\text { Northern Extraction } \\
\text { Well Field }\end{array}$ & 0.1 & 0.3 & 60 & 11,500 \\
\hline
\end{tabular}

The data used for these calculations were presentated in Clausen et al. (1995a) from drive-point profile samples. These calculations indicate the flux of TCE across a given cross-sectional area, generally decreases with distance from the source area. A TCE flux rate of $16 \mathrm{~kg} /$ year was calculated at the plant perimeter fence, 25 $\mathrm{kg} / \mathrm{year}$ at the DOE property boundary, $2.4 \mathrm{~kg} / \mathrm{yr}$ at Ogden Landing Road, and $0.1 \mathrm{~kg} / \mathrm{year}$ at the north extraction well field. Between the plant fence and DOE boundary the flux is essentially the same. Given that the isoconcentration cross-sections were developed from borings separated from 100 to $1000 \mathrm{ft}$ in the horizontal direction and vertical samples were collected on $10 \mathrm{ft}$ intervals by Clausen et al. (1995a), there could be some potential error associated with the flux rates. Therefore, the flux rates presented in Table 9 should not be considered absolute values. More detailed sampling would reduce the error associated with the flux calculations but the lack of permanent monitoring wells with the needed sampling points is not currently available For this reason, order of magnitude differences in flux rates are likely significant, but changes less than this may not signifcant.

The flux rate of TCE appears constant between the plant perimeter fence and DOE property boundary indicating no net loss of TCE, as mentioned above, but this may be an artifact of the availability of sampling locations. A constant flux suggests the active attenuating mechanisms to be dilution, dispersion, and advection. Changes in flux from the DOE property boundary to Ogden Landing Road, and to the northern extraction well field are significant. The possible mechanisms active in this region and potentially responsible for the reduction in flux are; sorbtion, diffiusion, and biodegradation. Dilution, dispersion, and advection are also active processes but they don't contribute to a reduction in flux, although they do contribute to a decrease in contaminant concentrations. However, several wells in this region (MW66, R2, and R113) actually exhibit increasing TCE concentrations, which began in 1994, as discussed in Section 5.2. This result seems to be consistent with the higher flux rate at the DOE property boundary than at the plant fence boundary. The agreement between the concentration data and flux rates suggests the previous discussion of possible errors in the flux rate calculations may not be warranted. If this is true, the data suggests a region of elevated TCE (i.e. a slug release of TCE) in 
relation to the overall plume. Since, the flux of TCE is unknown upgradient of the plant fence boundary, further attempts at explanation of this phenomen are not possible. A lack of suitably located wells perpindicular to the plume axis prevents an analysis of flux rates between the plant fence boundary and the source.

The overall flux of a contaminant at several locations within a plume is important, but for a definitive NA analysis the components contributing to a decline in flux must be known. Sorbtion and diffusion rates should be consistent throughout the aquifer but may vary due to differences in lithology. The overlying and underlying units in contact with the RGA tend to be finer and consist of clay towards the Ohio River, and coarser back towards the plant site. Additionally, sorbtion is concentration dependent and nonlinear (Curtis et al., 1986; Ball and Roberts, 1991; Allen-King et al., 1996). However, since field data are lacking for diffusion and sorbtion of TCE , they will not be discussed further and are assumed to be constant for this analysis.

As mentioned earlier, an assumption was made that sorbtion and diffusion are constant throughout the plume. Without specific studies these two parameters can not be individually quantified. Given the available data, it may be possible to separate out the contribution of bioedegradation from the other parameters; dilution, dispersion, advection, diffusion, and sorbtion. A geochemical model, BioScreen ${ }^{\mathrm{TM}}$, was utilized to calculate what percentage of the TCE reduction could be attributed to biological processes. Although this particular model was developed for evalauting reductive processes for petroleum hydrocarbons, (Weidemeier et al. (1997) point out it can be used for chlorinated solvent reductive processes if the results are interpretated with caution. Input of site specific parameters, calibrating to the known plume length, and assuming a TCE loss of $55,000 \mathrm{~kg}$ resulted in a determination that less than 10 percent of the reduction in TCE flux may be accounted for by biological processes. If the overall flux rate for each cross-section is normalized to a constant cross-sectional area at the DOE property boundary, the contribution of dilution, dispersion, and advection can be separated out assuming the rate of diffusion and sorbtion is constant throughout the aquifer. The analysis yields that dilution, dispersion, and advection account for approximately 90 percent of the observed decline in concetration levels in the Northwest Plume. Therefore, sorbtion and difussion likely account only for a few percent of the total attenuation variable.

From the above discussion, ten percent of the reduction in TCE levels can be attributed to biological destructive processes. Therefore, between the DOE property boundary and Ogden Landing Road $2.3 \mathrm{~kg}$ of TCE is being dechlorinated on an annual basis and $0.23 \mathrm{~kg}$ between Ogden Landing Road and the North Extraction Well Field. Clausen et al. (1995a) estimated that approximately 3200 to $4700 \mathrm{~kg}$ of dissolved TCE could be accounted for in the Northwest Plume. Assuming an annual $3 \mathrm{~kg}$ rate of TCE destruction and reliance solely on bioedegradation, it would take in excess of several hundred years for all of the TCE to be detroyed by biological processes. Another way to look at the destruction rate of TCE is through half-life calculations.

The reduction of TCE flux rates allows for a calculation of the half-life of TCE. For this analysis it is assumed the declining flux rate is solely a result of biodegradation with sorption and diffusion processes ignored. The Northwest contaminant plume between the north and south well fields has a one pore volume flush out rate of 10 years using a flow velocity of $1.3 \mathrm{ft} /$ day (Laase and Clausen, 1997). 
The following equation can be used to calculate the biodegradation rate constant;

\{4\} $K=1 / t \ln (a([a-x]))$

where

$\mathrm{K}=$ biodegradation rate constant,

$\mathrm{t}=$ time,

$a=$ initial flux rate,

$x=$ change in flux with time,

$\mathbf{n}=$ reaction order, $\mathbf{a}$ value of 1 is assumed for first order reaction.

Using equation 4, the biodegradation rate of TCE in the Northwest Plume varies from $2.6 \times 10^{-2}$ to $7.4 \times 10^{-2} \mathrm{yr}^{-1}$. It should be kept in mind, this calculation ignores sorbtion and diffusion. Although these mechanisms may only account for a few percent of the total NA process, they could have impact on the calculated biodegradation rate. If it were possible to factor in sorbtion and diffusion, the net result would be a lower biodegradation rate with a concomitant increase in half-life. In comparison, Barrio-Lage et al. (1986) determined a laboratory anaerobic biodegradation rate of $5.4 \times 10^{-3} \mathrm{yr}^{-1}$ and Howard et al. (1991) measured a value of $4.19 \times 10^{-4} \mathrm{yr}^{-1}$ for hydrolysis of TCE. Once K is calculated the half-life of TCE can be calculated using

\section{\{5\} $\quad t_{1 / 2}=\ln \left(C / C_{0}\right) / K$}

where

$\mathrm{C}=$ initial TCE flux rate

$\mathrm{C}_{\mathrm{o}}=$ final flux rate

The corresponding TCE half-life in the Northwest Plume between the DOE property boundary on the northern extraction well field is greater than 25 years. In comparison, laboratory half-lives for TCE have been calculated; 4.5 years for anaerobic degradation (Barrio-Lage et al., 1986), six months to one year for aerobic degradation (Tabak et al., 1981), and 10.7 month to 4.5 years for hydrolysis (Dilling et al., 1975). Thus, based on the calculated NA rate TCE concentrations, downgradient of the extraction well fields in the Northwest Plume, will remain above the MCL in excess of 100 years, even though the existing containment system has cut off the plume from the source. For the region upgradient of the southernmost extraction well field the NA rate is irrelavent since this region is being fed by DNAPL. TCE levels will remain above the MCL until the DNAPL source is depleted. Owing to the uncertainity of the volume of DNAPL beneath C-400 a calculation of the time to reach the $\mathrm{MCL}$, for the region upgradient of the southernmost extraction well field, via NA mechanisms is not possible.

As mentioned in Section 5.6, no known biological processes are available for the destruction or reduction in toxicity or mobility of ${ }^{99} \mathrm{Tc}$. The ${ }^{99} \mathrm{Tc}$ results indicate no change in net flux throughout the Northwest Plume which is consistent with a lack of destructive or removal mechanism to reduce ${ }^{99} \mathrm{Tc}$ in solution, e.g. precipitation or sorbtion. Natural radioactive decay of ${ }^{99} \mathrm{Tc}$ is a destructive process, unfortunately the half-life of ${ }^{99} \mathrm{Tc}(210,000$ years) makes this an unsuitable mechanism for NA purposes. The flux of ${ }^{99} \mathrm{Tc}$ at the plant fence boundary, DOE property boundary, Ogden Landing Road, and at the extraction well field in the Northwest Plume is $0.4,0.5,0.4$, and $0.3 \mathrm{Ci}$ /year, respectively (Table 9). Advection, dispersion, and dilution have the net effect of spreading the cross-sectional area of the plume, but the net flux remains the same since there is no destructive mechanism. However, advection, dispersion, and dilution do result in a decline in ${ }^{99} \mathrm{Tc}$ levels with increasing distance from the source. 


\subsubsection{Northeast Plume}

Similar calculations could not be performed for the Northeast Plume due to a lack of suitable sampling points perpindicular to the plume axis at varying distances downgradient from the source. It is expected that the conditions and attenuating mechansims in the Northeast Plume are similar to those in the Northwest Plume. The lack of significant geochemical differences between the two plumes appears to validate this assumption. Therefore, half-lives of TCE calculated for the Northwest Plume are applicable to the Northeast Plume.

\section{CONCLUSIONS}

NA processes such as biodegradation, sorption, dilution, dispersion, advection, and possibly sorbtion and diffusion are occuring in the Northeast and Northwest plumes. However, the overall biological attenuation rate for TCE within the plumes is not sufficiently rapid to utilize as remedial option. The mobility and toxicity of ${ }^{99} \mathrm{Tc}$ is not being reduced by attenuating procesess within the Northwest Plume. The current EPA position is that NA is not a viable remedial approach unless destructive processes are present or processes are active which reduce the toxicity and mobility of a contaminant (EPA, 1997; Kramer, 1997; Tulis, 1997; and Wischkaemper, 1997). Therefore, active remediation of the dissolved phase plumes will be neccessary to reduce contaminant concentrations before an NA approach could be justified at PGDP for either plume. Possible treatment methods for the reduction of dissolved phase concentrations within the plumes are pump-and-treat, bioagumentation, biostimulation, or multiple reactive barriers. Another possibility is the use of a regulatory instrument such as an Alternate Concentration Limit (ACL) petition.

Biodegradation of TCE is occuring in both plumes and several hypothesis are possible to explain the apparent conflicts with some of the geochemical data. The first hypothesis is active intrinsic bioremediation is negligible or so slow to be nonmeasurable. In this scenario, the $\mathrm{D}$. O., chloride, TCE, and isotopic results are indicative of past microbiological reactions. It is surmised in this scenario, that when the initial TCE release occurred, sufficient energy sources were available for microorganisms to drive aerobic reduction of TCE, but these energy sources were rapidly depleted. The initial degraded TCE has since migrated to downgradient locations.

In the second scenario, TCE anaerobic degradation occurs in organic-rich micro-environments within a generally aerobic aquifer. TCE may be strongly absorbed to organic-rich materials in the aquifer matrix and degraded by local communities of microbes, perhaps even under anaerobic conditions. Chloride, generated by degradation in such microenvironments is released rapidly into the water, as is $\mathrm{CO}_{2}$, from respiration of the microorganisms. TCE and its organic degradation products are retained on the aquifer matrix, by sorption, and released more slowly into the groundwater. In this process, chloride produced from the microbial reaction may become separated in the plume from the residual TCE. This may explain why the chloride isotope ratio and dissolved TCE do not correlate with the DIC isotope ratio. The relationship between the $\delta^{37} \mathrm{Cl}$ values of TCE and dissolved inorganic chloride is consistent with what would be expected from the degradation of TCE, but is complicated by the elevated levels of background chloride, presumably due to agriculture practice, and complex behavior of TCE in the aquifer.

Other key observations obtained through this study include the following:

- There is no evidence for the reduction of ${ }^{99} \mathrm{Tc}$ levels through precipitation or sorption. The dominant NA mechanisms for ${ }^{99} \mathrm{Tc}$ are advection, dispersion, and dilution. 
- Hydrogen and electron acceptor results, when screened with the Wiedemeier et al. (1996) criteria, from this study suggest a lack of TCE reduction by anaerobic processes.

- Anaerobic degradation processes are unsupported by concentration profiles of methane, sulfate, hydrogen sulfide, nitrate, ferrous and ferric iron, and D. O., along the flow path for both plumes.

- Low levels of cis-1,2-DCE ( $<0.050 \mathrm{mg} / \mathrm{L})$, a direct anaerobic degradation product of TCE, were observed in this study, however, later stage degradation products such as VC, ethylene, ethane, and chloroethane were not detected. The analytical detection limits for these compounds were in the tens of ppb.

- Increasing chloride levels along the flow path of both plumes, comparison with background chloride levels, as well as the isotopic data, suggest chloride production from the reductive dehalogenation of TCE.

- The negative correlation of D. $O$. with $8^{37} \mathrm{Cl}$ of TCE suggests consumption of oxygen and dehalogenation of TCE. This observation is supported by the correlations of $8^{37} \mathrm{Cl}$ TCE with TCE concentration as well as $8^{37} \mathrm{Cl}$ of TCE with $8^{37} \mathrm{Cl}$ of DIC.

- The classic approach for evaluating reductive dechlorination of aliphatic chlorinated compounds, such as presented by Wiedemeier et al. (1997) and Chapelle et al. (1995) may not be applicable to all sites, especially those with slow rates of biological dechlorination.

- D. O. levels throughout the RGA in both contaminated and uncontaminated regions are consistently greater than $1 \mathrm{mg} / \mathrm{L}$, for the most part, indicating aerobic conditions.

- Flux calculations for the Northwest Plume suggest reduction in TCE mass may be spatially specific throughout the RGA.

- Intra well trending analysis for MW66, R2, and R113, located within the hotspot of the Northwest Plume, indicates a statistically significant increase in TCE and ${ }^{99} \mathrm{Tc}$ levels, which suggests the core of the plume is not in equilibrium.

- No evidence was found for the reduction of TCE by native iron.

- The lack of TCE degradation products was not masked by analytical dilution, a criticism of previous studies at PGDP.

\section{RECOMMENDATIONS}

Further efforts are not recommended for evaluating NA processes within the aquifer at the PGDP site. Furthermore, microcosm studies are not recommended even though the data from this study exhibited conflicting results in some cases. However, microcosm studies may prove useful if a biostimulation or bioagumentation approach is evaluated for either plume. In this case, natural intrinsic biodegradation rates will be needed to compare with engineered bioremediation rates to determine if biological manipulation is warranted as a remedial approach. 
Further evaluation of the impact of the Ohio River system on the RGA may be needed to quantify the rates of dispersion and dilution if an ACL approach is selected for plume management. Evaluation of these attenuation processes will require quantifying the transmissivity of the RGA in the near Ohio River area.

Also, the interaction of contaminants with the Ohio River sediments and discharge into surface water should be evaluated to see what role, if any, sorption, precipitation, bioremediation, and phytoreduction may play. Fryar (1997) has speculated that water from the RGA may intersect surface water bodies such as streams and ponds before reaching the Ohio River. A study may be appropriate to investigate this possibility. If it is proven RGA water is recharging surface water prior to the Ohio River the geochemical makeup of the sediments in these surface water bodies and any associated wetlands should be evaluated for possible reduction, sorption, or precipitation of TCE and ${ }^{99} \mathrm{Tc}$. NA processes at the aquifer/river boundary may prove to be significant if the regulatory agencies find the current contaminant levels within the dissolved phase plumes to be acceptable.

DOE should consider evaluating the applicability of an ACL petition, which could be tied to the existing containment systems in operation at the Northeast and Northwest plumes. The current size of the plumes, in excess of 2.5 miles in length and over 6 billion gallons of contaminated water, may rule out active remedial measures as a cost effective approach to plume management. 


\section{REFERENCES}

Aggarwal, P. K. and R. E. Hinchee. 1996. Monitoring in situ biodegradation of hydrocarbons by using stable carbon isotopes. Environmental Science and Technology. 25: 1178-1180.

Aggarwal, P. K, M. E. Fuller, M. M. Gurgas, J. F. Manning, and M. A. Dillon. 1997. Use of stable oxygen and carbon isotope analysis for monitoring the pathways and rates of intrinsic and enhanced in situ biodegradation. Environmental Science and Technology. 31:590-596.

Allard, B., H. Kigatsi, and B. Torstenfelter. 1979. Technetium: Reduction and sorption in granite bedrock. Radiochemistry and Radioanalytical Letters. 37: 223-230.

Allen-King, R. M., V. H. Groenevelt, C. J. Warren, and D. M. Mackay. 1996. Non-linear chlorinated-solvent sorption in four aquitards. Journal of Contaminant Hydrology. 22:203-221.

Alvarez-Cohen, L., P. L. McCarty, E. Boulygina, R. S. Hanson, G. A. Brusseau, and H. C. Tsien. 1992. Characterization of a methane-utilizing bacterium from a bacterial consortium that rapidly degrades trichloroethylene and chloroform. Applied and Environmental Microbiology. 58: 1886-1893.

Baedecker, M. J. and W. Back. 1979. Hydrogeological processes and chemical reactions at a landfill. Groundwater. 17:429-437.

Baedecker, M. J., D. I. Siegel, P. Bennett, and I. Cozzarelli. 1988. The fate and effects of crude oil in a shallow aquifer. U. S. Geological Survey Toxic Substances Hydrology Program, Proceedings of the Technical Meeting, Phoenix Arizona, September 26-30. U. S. Geological Survey Water Resources Investigation Report 88-420. p. 13-20.

Ball, W. P. and P. V. Roberts. 1991. Long-term sorption of halogenated organic chemicals by aquifer material, 1. Equilibrium. Environmental Science and Technology. 25:1223-1226.

Ball, W. P. and P. V. Roberts. 1992. Comments on long-term sorption of halogenated organic chemicals by aquifer materials, 1: Equilibrium. Environmental Science and Technology. 26: 2301-2302.

Barker, J. F. and P. Fritz. 1991. The occurrence and origin of methane in some groundwater flow systems. Canadian Journal of Earth Sciences. 18:1802-1816.

Barrio-Lage, G. A., F. Z. Parsons, R. S. Nassar. and P. A. Lorenzo. 1986. Sequential dehalogenation of chlorinated ethenes. Environmental Science and Technology. 20: 96-99.

Barrio-Lage, G. A., F. Z. Parsons, R. S. Nassar. and P. A. Lorenzo. 1987. Biotransformation of trichloroethylene in a variety of subsurface materials. Environmental Toxicology and Chemistry. 6: 571-579.

Bouwer, E. J. B. and P. L. McCarty. 1981. Biofilm degradation of trace chlorinated organics. In Proceedings of the American Society of Civil Engineers Environmental Engineering Division Specialty Conference, p. 196202. Atlanta, GA. ASCE. 
Bouwer, E. J., B. E. Rittmann, and P. L. McCarty. 1981. Anaerobic degradation of halogenated 1- and 2-carbon organic compounds. Environmental Science and Technology. 15: 596-599.

Bouwer, E. J. and P. L. McCarty. 1982. Removal of trace chlorinated organic compounds by activated carbon and fixed-film bacteria. Environmental Science and Technology. 16: 836-843.

Bouwer, E. J. and P. L. McCarty. 1983. Transformations of 1- and 2-carbon halogenated aliphatic organic compounds under methanogenic conditions. Applied and Environmental Microbiology. 45: 1286-1294.

Bouwer, E. J. 1994. Bioremediation of chlorinated solvents using alternate electron acceptors, In Handbook of Bioremediation. Lewis Publishers. p. 149-175.

Bradley, P. M. and F. H. Chapelle. 1996. Anaerobic mineralization of vinyl chloride in Fe(III)-reducing, aquifer sediments. Environmental Science and Technology. 30: 2084-2086.

Broholm, K., T. H. Christensen, and B. K. Jensen. 1993. Different abilities of eight mixed cultures of methaneoxidizing bacteria to degrade TCE. Water Research. 27: 215-224.

Brookins, D. G. 1988. Eh-pH Diagrams for Geochemistry. Springer-Verlag. New York.

Bulger, P. R, A. E. Kehew, and R. A. Nelson. 1989. Dissimilatory nitrate reduction in waste-water contaminated aquifer. Ground Water. 27:664-671.

CH2M Hill. 1990. Results of the Site Investigation, Phase I, at the Paducah Gaseous Diffusion Plant, Paducah, Kentucky. KY/ER-4.

CH2M Hill. 1992. Results of the Site Investigation, Phase II, at the Paducah Gaseous Diffusion Plant, Paducah, KY. KY/SUB 13 B-97777 CP-03/1991.

Chapelle, F. H. and D. R. Lovley. 1992. Competitive exclusion of sulfate reduction by Fe(III)-reducing bacteria: A mechanism for producing discrete zones of high-iron ground water. Ground Water. 30:29-36.

Chapelle, F.H. 1993. Ground-Water Microbiology and Geochemistry. John Wiley \& Sons, Inc. New York.

Chapelle, F. H., P. B. McMahon, N. M. Dubrovsky, R.F. Fuji, E. T. Oaksford, and D. A. Vroblesky. 1995. Deducing the distribution of terminal electron-accepting processes in hydrologically diverse groundwater systems. Water Resources Research. 31:359-371.

Chiang, S. Y., X. Wang, J. Wynn, and F. M. Saunders. 1997 (in press). Intrinsic bioremediation of acetone and aromatic compounds using wetland sediments under methanogenic conditions. EOS.

Clausen, J.L., K.R. Davis, J.W. Douthitt, and B.E. Phillips. 1992. Report of the Paducah Gaseous Diffusion Plant Groundwater Investigation, Phase III. Martin Marietta Energy System. Paducah, KY. KY/E-150.

Clausen, J. L., J. L. Zutman, and N. D. Farrow. 1993. Characterization of the Northwest Plume Utilizing a Driven Discrete-Depth Sampling System. Martin Marietta Energy Systems. Paducah, KY. KY/ER-22. 
Clausen, J. L., J. L. Zutman, D. A. Pickering, and N. D. Farrow. 1995a. Final Report on Drive-Point Characterization of the Northwest Plume at the Paducah Gaseous Diffusion Plant and Analysis of Related Data. Martin Marietta Energy Systems. Paducah, KY. KY/ER-66.

Clausen, J. L., W. L. Richards, N. E. Korte, and L. Liang. 1995b. ORNLMMES Research Into Remedial Applications of Zero-Valence Metals. 3: Removal of TCE, cis-1,2-DCE, Vinyl Chloride and Technetium. American Chemical Society Symposium on Reductive Dehalogenation. April 2-7. Anaheim, CA. pp. 755-758.

Coleman, D. D., W. F. Meents, C. L. Liu, and R. A. Keogh. 1997. Isotopic Identification of Leakage Gas from Underground Storage Reservoirs-A Progress Report. Illinois State Geological Survey. Champaign, IL.

Craig $\mathrm{H}$. 1957. Isotopic standards for carbon and oxygen and correction factors for mass spectrometric analysis of carbon dioxide. Geochimica et Cosmochimica Acta. 12: 133-149.

Craig, H. 1961. Standard for reporting concentrations of deuterium and oxygen-18 in natural waters. Science. 133: 1833-1834.

Curtis, G. P., P. V. Roberts, and M. Reinhard. 1986. An Natural gradient experiment on solute transport in a sand aquifer, 4. Sorption of organic solvents and its influence on mobility. Water Resources Research. 22: 2059-2067.

Dansgaard, W. 1964. Stable isotopes in precipitation. Tellus. 16: 436-468.

Dayan, H., T. Abrajano, L. Heraty, L. Huang, and N. Sturchio. 1997. Isotopic fractionation during reductive dehalogenation of chlorinated ethenes by metallic iron. Geological Society of America Annual Meeting. October 20-23. Salt Lake City, UT.

Dilling, W. L., N. B. Terfertiller, G. J. Kallos. 1975. Evaporation rates and reactivities of methylene chloride, chloroform, 1,1,1-TCA, TCE, PCE, and other chlorinated compounds in dilute aqueous solutions. Environmental Science and Technology. 9: 833-838.

DOE. 1996. Northeast Plume Preliminary Characterization Summary Report. Lockheed Martin Energy Systems. Kevil, KY. DOE/OR/07-1339/V1 \&D2.

DOE. 1997. Remedial Investigation Report for Solid Waste Management Units $7 \& 30$ of Waste Area Grouping 22 at Paducah Gaseous Diffusion Plant Paducah, Kentucky. Science Applications International Corporation. Oak Ridge, TN. DOE/OR/07-1604/V1\&D0.

Douthitt, J. W. and B. E. Phillips. 1991. Stratigraphic controls on contaminant migration in fluvial lacustrine sediments near Paducah, Kentucky. Geological Society of America Southeast-Northeast Meeting. March 1416. Baltimore, $\mathrm{MD}$.

Enzien, M. V., F. Picardal, T. C. Hazen, R. G. Arnold, and C. B. Fliermans. 1994. Reductive dechlorination of trichloroethylene and tetrachloroethylene under aerobic conditions in a sediment column. Applied and Environmental Microbiology. 60: 2200-2204.

EPA. 1996a. Symposium on Natural Attenuation of Chlorinated Organics in Groundwater, Dallas, TX, Septemeber 11,13. U. S. Environmental Protection Agency. EPA/540/R-96/509. Washington, DC. 
EPA. 1996b. Bioscreen Natural Attenuation Decision Support System User's Manual Version 1.3.

U. S. Environmental protection Agency. EPA/600/R-96/087. Washington, DC.

EPA. 1997 (draft). Draft Region 4 Approach to Natural Attenuation of Chlorinated Solvents. U. S. Environmental Protection Agency. Atlanta, GA.

Fan, S. and K. M. Scow. 1993. Biodegradation of trichloroethylene and toluene by indigenous microbial populations in soil. Applied and Environmental Microbiology. 59: 1911-1918.

Fields, T. Jr. 1997 (draft). Use of Monitored Natural Attenuation at Superfund, RCRA Corrective Action, and UST Sites. Memo to Regional Adminstrators. U. S. Environmental Protection Agency.

Fogel, M. M. A. R. Taddeo, and S. Fogel. 1986. Biodegradation of chlorinated ethenes by a methane-utilizing mixed culture. Applied and Environmental Microbiology. 51:720-724.

Freedman, D. L. and J. M. Gossett. 1989. Biological reductive dehalogenation of tetrachloroethylene and trichloroethylene to ethylene under methanogenic conditions. Applied and Environmental Microbiology. 55: 1009-1014.

Freeze, R. A. and J. A. Cherry. 1979. Groundwater. Prentice-Hall, Inc. Englewood Cliffs, NJ. 604 p.

Fryar A. E. 1997. Subsurface Degradation and Sorbtion of Chloroethenes in the Vicinity of the Paducah Gaseous Diffusion Plant. Report prepared for the University of Kentucky Federal Facilities Oversight Unit. University of Kentucky. Lexington, KY.

Gu, B., J. L. Clausen, J. A. McDonald, and J. F. McCarthy. 1994. Assessment of the Influences of Groundwater Colloids on the Migration of Technetium-99 at the Paducah Gaseous Diffusion Plant Site in Paducah. Kentucky. Oak Ridge National Laboratory. Oak Ridge, TN. ORNL/TM-12747.

Gu, B. and K. E. Dowlen. 1996. An Investigation of Groundwater Organics, Soil Minerals, and Activated Carbon on the Complexation, Adsorbtion, and Separation of Technetium-99. Oak Ridge National Laboratory. Oak Ridge, TN. ORNL/TM-13154.

Hach. 1992. Hach Analysis Handbook. Hach Company. Loveland, CO.

Hanson, R. S. 1980. Ecology and diversity of methylotrophic organisms. Advanced Applied Microbiology. 26: 3-39.

Henry, S. M. and D. Grbic-Galic. 1991. Influence of endogenous and exogenous electron donors and trichloroethylene oxidation toxicity on trichloroethylene oxidation by methanotrophic cultures from a groundwater aquifer. Applied and Environmental Microbiology. 57: 236-244.

Hill, J., IV, H. P. Kollig, D. F. Paris, N. L. Wolfe, and R. G. Zep. 1976. Dynamic Behavior of Vinyl Chloride in Aquatic Ecosystems. U. S. Environmental Protection Agency. EPA-600/3-76-001. Springfield, VA.

Holt B. D., N. C. Sturchio, G. B. Arehart, and A. J. Bakel. 1995. Ultrasonic vacuum extraction of gases from water for chemical and isotopic analysis. Chemical Geology (Isotope Geoscience Section). 122: 275-284. 
Holt, B. D., N. C. Sturchio, T. Abrajano, and L. Heraty. 1997 (in press). Conversion of chlorinated volatile organic compounds to carbon dioxide and methyl chloride for isotopic analysis of carbon and chlorine. Analytical Chemistry.

Hopkins, G. D. and P. L. McCarty. 1995. Field evaluation of in situ aerobic cometabolism of trichloroethylene and three dichloroethylene isomers using phenol and toluene as the primary substrates. Environmental Science and Technology. 29: 1628-1637.

Jackson, R. E. and R. J. Patterson. 1982. Interpretation of $\mathrm{pH}$ and Eh trends in a fluvial-sand aquifer system. Water Resources Research. 18: 1255-1268.

Jacobs Engineering. 1997. Groundwater Restoration Potential and Natural Attenuation at the Paducah Gaseous Diffusion Plant, Paducah, Kentcuky. Letter to DOE, September 15, 1997.

Kearl, P. M. 1993. Colloidal Borescope Investigation at Paducah Gaseous Diffusion Plant. Oak Ridge National Laboratory. Grand Junction, CO.

Kishima, N. and H. Sakai. 1980. Oxygen-18 and deuterium determination on a single water sample of a few milligrams. Analytical Chemistry. 52: 356-358.

Kramer, F. 1997. Personal Communication. U. S. Environmental Protection Agency. Washington, DC.

Laase, A. D. and J. L. Clausen. 1997. Paducah Gaseous Diffusion Plant Northwest Plume Interceptor System Evaluation. Oak Ridge National Laboratory. Oak Ridge, TN. ORNL/TM-13333.

Langmuir, D. 1969. Geochemistry of iron in Coastal-Plain ground water of the Camden, New Jersey, area. $U$. S. Geological Survey Professional Paper 650-C. p. C224-C235.

Lanzarone, N. A. and P. L. McCarty. 1990. Column studies on methanotrophic degradation of trichloroethylene and 1,2-dichloroethylene. Ground Water. 28: 910-919.

Lindbergh, R. D. and D. D. Runnells. 1984. Ground water redox reactions: An analysis of equilibrium state applied to Eh measurements and geochemical modeling. Science. 225: 925-927.

Little, C. D., A. V. Palumbo, S. E. Herbes, M. E. Lidstrom, R. L. Tyndall, and P. J. Gilmer. 1988. Trichloroethylene biodegradation by a methane-oxidizing bacterium. Applied and Environmental Microbiology. 54: 951-956.

Long, A., C. J. Eastoe, R. S. Kaufmann, J. G. Martin, L. Wirt, and J. B. Finley. 1993. High precision measurement of chlorine stable isotopes. Geochimica et Cosmochimica Acta. 57: 2902-2912.

Lovley, D. R. and E. J. P. Phillips. 1986. Availability of ferric iron for microbial reduction in bottom sediments of the freshwater tidal Potomac River. Applied and Environmental Microbiology. 52: 751-757.

Lovley, D. R. and E. J. P. Phillips. 1987. Competitive mechanisms for inhibition of sulfate reduction and methane production in the zone of ferric iron reduction in sediments. Applied and Environmental Microbiology. 53: $2636-2641$. 
Lovley, D. R. and S. Goodwin. 1988. Hydrogen concentrations as an indicator of the predominant terminal electron-accepting reactions in aquatic sediments. Geochmica et Cosmochimica Acta. 52: 2993-3003.

Lovley, D. R, M. J. Baedecker, D. J. Lonergan, I. M. Cozzarelli, E. J. P. Phillips, and D. I. Siegel. 1989. Oxidation of aromatic contaminants coupled to mircrobial iron reduction. Nature. 339: 297-300.

Lovley, D. R, F. H. Chapelle, and J. C. Woodward. 1994. Use of dissolved $\mathrm{H}_{2}$ concentrations to determine distribution of microbially catalyzed redox reactions in anoxic groundwater. Environmental Science and Technology. 28:1205-1210.

Malachowsky, K. J., T. J. Phelps, A. B. Teboli, D. E. Minnikin, and D. C. White. 1994. Aerobic mineralization of trichloroethylene, vinyl chloride, and aromatic compounds by Rhodococcus species. Applied and Environmental Microbiology. 60: 542-548.

McCarty, P. L. and L. Semprini. 1994. Ground-water treatment for chlorinated solvents, In Handbook of Bioremediation. Lewis Publishers. Boca Raton, FL.

McClellen, K. L., N. Buras, and R. C. Bales. 1989. Biodegradation of trichloroethylene by bacteria indigenous to a contaminated site. Journal of Environmental and Scientific Health. 6: 561-570.

McConnell, C. L. 1992. A Steady State Computer Model of the C-404 Landfill Area in Clausen J. L. et al., 1992. Resource Conservation and Recovery Act Part B Permit Modification for Inclusion of the C-404 LowLevel Radioactive/Hazardous Waste Landfill. Martin Marietta Energy Systems. Paducah, KY. KY/E-129.

McMahon, P. B., F. H. Chapelle, W. F. Falls, and P. M. Bradley. 1992. Role of microbial processes in linking sandstone diagenesis with organic-rich clays. Journal of Sediment Petrology. 62:1-10.

Mitsch, W. J. and J. G. 1993. Wetlands. New York. Van Nostrand Reinhold. 722p.

MMES. 1993. PGDP ER\&WM Field Operations Procedure Manual. Martin Marietta Energy Systems, Inc. Paducah, KY.

Moore, G. K. and J. L. Clausen. 1997. Analysis and Interpretation of Water levels in Observation Wells at Paducah Gaseous Diffusion Plant, 1990-1997. Lockheed Martin Energy Systems. Kevil, KY. KY/EM-210.

Mu, D. Y. and K. M. Scow. 1994. Effect of trichloroethylene (TCE) and toluene concentrations on TCE and toluene biodegradation and the population density of TCE and toluene degraders in soil. Applied and Environmental Microbiology. 60: 2661-2665.

Murray, W. D. and M. Richardson. 1993. Progress toward the biological treatment of $C_{1}$ and $C_{2}$ halogenated hydrocarbons. Critical Reviews in Environmental Science and Technology. 23:195-217.

NCP. 1996. National Contigency Plan. 40CFR

Nyer, E. K. and M. J. Gearhart. 1997. Plumes don't move. Ground Water Monitoring and Remediation. Winter: 52-55 
Oldenhuis, R, R. L. Vink, B. J. Janssen, and B. Witholt. 1989. Degradation of chlorinated aliphatic hydrocarbons by methylosinus trichosporium $\mathrm{OB} 3 \mathrm{~b}$ and toxicity of trichloroethylene. Applied Environmental Microbiology. 55: 2819-2826.

Oldenhuis, R., J. Y. Oedzes, J. J. Van der Waarde, and D. B. Janssen. 1991. Kinetics of chlorinated hydrocarbon degradation by methylosinus trichosporium OB3b and toxicity of TCE. Applied Environmental Microbiology. 57: 7-14.

Paquette, J., J. A. K. Reid, and E. L. J. 1980. Review of technetium behavior in relation to nuclear waste disposal. Whiteshell Nuclear Research Establishment. Pinawo, Manitoba. TR-25.

Pardue, J. H., R. D. DeLaune, D. D. Adrian, W. H. Jr. 1993. Reductive dechlorination of hexachlorobenzene in wetlands soils, in Sorption and Degradation of Pesticides and Organic Chemicals in Soils. D. M. Linn, F. H. Carski, M. L. Brusseau, and T. H. Chang Eds. Soil Science Society of America Special Publication 32. pp. 145-152.

Pearson, C. R. and G. McConnell. 1975. Chlorinated $C_{1}$ and $C_{2}$ hydrocarbons in the marine environment. Proceedings of the Royal Society London Service Bulletin. 189: 305-332.

Phelps, T. E. 1997. Personal Communication. Oak Ridge National Laboratory. Oak Ridge, TN.

Phillips, B. E. 1996. Aquifer Test Analysis of the Northwest Plume, Paducah Gaseous Diffusion Plant, Paducah, Kentucky. Lockheed Martin Energy Systems. Paducah, KY. KY/EM-145.

Piwoni, M. D. and P. Banerjee. 1989. Sorption of volatile organic solvents from aqueous solution onto subsurface solids. Journal of Contaminant Hydrology. 4: 163-179.

Plummer, L. N., J. F. Busby, R. W. Lee, and B. B. Hanshaw. 1990. Geochemical modeling of the Madison Aquifer in parts of Montana, Wyoming, and South Dakota. Water Resources Research. 26:1981-2014.

Richards, W. L. 1997. Personal communication. Lockheed Martin Energy Systems, Inc. Paducah, KY.

Rittman, B. E., E. J. Bouwer, J. E. Schreiner, and P. L. McCarty. 1980. Biodegradation of Trace Organic Compounds in Groundwater Systems. Stanford University. Stanford, CA. Technical Report 255.

Semprini, L., G. D. Hopkins, P. V. Roberts, D. Grbic-Galic, and P. L. McCarty. 1991. Ground Water. 29: 239250.

Solomon, D. K. 1995. Potential for stabilization of the Northwest Plume due to dilution and biogeochemical transformations. University of Utah.

Strand, S. E., M. D. Bjelland, and H. D. Stensal. 1990. Kinetics of chlorinated hydrocarbon degradation by suspended cultures of methane-oxidizing bacteria. Research Journal World Pollution Control Federation. 62: 124-129.

Stumm, W. and J. J. Morgan. 1981. Aquatic Chemistry. John Wiley \& Sons. New York, NY. 
Sturchio, N., T. Abrajano, L. Heraty, L. Huang, and J. Clausen. 1997. Stable isotopic investigation of Natural Attenuation of TCE at the Paducah Gaseous Diffusion Plant. Geological Society of America National Meeting. October 20-23. Salt Lake City, UT.

Tabak, H. H., S. A. Quave, C. I. Mashni, and E. F. Barth. 1981. Biodegradability studies with organic priority pollutant compounds. Journal of the Water Pollution Control Federation. 53: 1503-1518.

Terran 1990. Aquifer Assessment Report - Groundwater Monitoring Phase II C-404 Aquifer Testing Program.

Terran. 1992. Aquifer Assessment report - Groundwater Monitoring Phase III: Aquifer Test Program West of Building C-333, Paducah Gaseous Diffusion Plant, Paducah, Kentcuky. Report No. TK-9213, ESO 16905.

Thorstenson, D. C., D. W. Fisher, and M. G. Croft. 1979. The geochemistry of the Fox Hills-Basal Hell Creek aquifer in southwestern North Dakota and northwestern South Dakota. Water Resources Research. 15:14791498.

Thorstenson, D. C. 1984. The Concept of Electron Activity and its Relation to Redox Potentials in Aqueous Geochemical Systems. U. S. Geological Survey Open-File Report, 84-072.

Tulis, D. S. 1997. Issues Associated with Natural Attenuation. http://www.epa.gov/swerist 1/rbdm/issues.htm.

Van Warmerdam, E. M., S. K. Frape, R. Araveno, R. J. Drimmie, and J. A. Cherry. 1995. Stable chlorine and carbon isotope measurements of selected organic solvents. Applied Geochemistry. 10: 547-552.

Vogel, T. M. and P. L. McCarty. 1985. Biotransformation of tetrachloroethylene to trichloroethylene, dichlorethylene, vinyl chloride, and carbon dioxide under methanogenic conditions. Applied Environmental Microbiology. 59:1080-1083.

Vogel, T. M. 1994. Natural bioremediation of chlorinated solvents, In Handbook of Bioremediation. Lewis Publishers. Boca Raton, FL.

Vroblesky, D. A. and F. H. Chapelle. 1994. Temporal and spatial changes of terminal electron-accepting processes in a petroleum hydrocarbon contaminated aquifer and the significance for contaminant biodegradation. Water Resources Research. 30:1561-1570.

Wiedemeier, T. H., J. T. Wilson, D. H. Kampbel, R. N. Miller, and J. E. Hansen. 1995. Technical Protocol for Implementating Intrinsic Remediation with Long-Term Monitoring for Natural Attenuation for Fuel Contamination Dissolved in Groundwater. Air Force Center for Environmental Excellence. Brooks Air Force Base. San Antonia, TX.

Wiedemeier, T. H., M. A. Swanson, D. A. Moutoux, E. K. Gordon, J. T. Wilson, B. H. Wilson, D. H. Kampbell, J. E. Hansen, P. Haas, and F. H. Chapelle. 1996. Technical Protocol for Evaluating Natural Attenuation of Chlorinated Solvents in Groundwater. Air Force Center for Environmental Excellence. Brooks Air Force Base. San Antonio, TX.

Wilson, J. T, J. F. McNabb, B. H. Wilson, and M. J. Noonan. 1983. Biotransformation of selected organic pollutants in ground water. Developments in Industrial Microbiology. 24: 225-233. 
Wilson, J. T. and B. H. Wilson. 1985. Biotransformation of trichloroethylene in soil. Applied and Environmental Microbiology. 49:242-243.

Wischkaemper, K. 1997. Personal Communication. U. S. Environmental Protection Agency. Atlanta, GA. 


\section{ACKNOWLEDGMENTS}

The authors would like to acknowledge the LMES field sampling crew of Jimmy Hicks and Jeff Boulton for their support in the field. Also credit goes to Kirk Roemer ORNL/GJ for developing the figures in this document. 
APPENDIX A

NATURAL ATTENUATION STUDY DATA 


\begin{tabular}{|c|c|c|}
\hline Analyte & MW103 (Background) & MW194 (Background) \\
\hline Sample Number & $5372-97$ & $5380-97$ \\
\hline Depth to Water ${ }^{2}$ (ft) & 60.65 & 23.50 \\
\hline Specific Conductance ${ }^{2}$ (umhos $/ \mathrm{cm}$ ) & 209 & 248 \\
\hline Dissolved Oxygen ${ }^{2}(\mathrm{mg} / \mathrm{L})$ & 3.7 & 6.1 \\
\hline Dissolved Oxygen ${ }^{1}(\mathrm{mg} / \mathrm{L})$ & 4.4 & 7.0 \\
\hline Temperature ${ }^{2}\left({ }^{\circ} \mathrm{C}\right)$ & 17 & 16 \\
\hline $\mathrm{pH}^{2}$ (units) & 6.2 & 5.9 \\
\hline $\mathrm{Eh}^{2}(\mathrm{mv})$ & +191 & +178 \\
\hline Hydrogen ${ }^{1}(\mathrm{nM})$ & $<0.22$ & $<0.22$ \\
\hline Methane $^{1}$ (ppm) & $<0.001$ & $<0.001$ \\
\hline Nitrogen $^{1}(\mathrm{ppm})$ & 27.1 & 26.0 \\
\hline $\operatorname{Argon}^{1}(\mathrm{ppm})$ & 0.9 & 0.9 \\
\hline Ethane (ug/L) & $<30$ & $<30$ \\
\hline Ethene (ug/L) & $<30$ & $<30$ \\
\hline $1,1,1-\mathrm{TCA}(\mathrm{ug} / \mathrm{L})$ & $<5$ & $<5$ \\
\hline $1,1,1-\mathrm{TCA}$ (ug/L) & $<5$ & $<5$ \\
\hline $1,1-\mathrm{DCA}(\mathrm{ug} / \mathrm{L})$ & $<5$ & $<5$ \\
\hline 1,1-DCE (ug/L) & $<5$ & $<5$ \\
\hline 1,2-DCE (ug/L) & $<5$ & $<5$ \\
\hline Benzene (ug/L) & $<5$ & $<5$ \\
\hline Bromodichloromethane (ug/L) & $<5$ & $<5$ \\
\hline Carbon Tetrachloride (ug/L) & $<5$ & $<5$ \\
\hline Chloroethane (ug/L) & $<5$ & $<5$ \\
\hline cis-1,2-DCE $(\mathrm{ug} / \mathrm{L}$ ) & 2 & $<1$ \\
\hline Ethylbenzene (ug/L) & $<5$ & $<5$ \\
\hline PCE (ug/L) & $<5$ & $<5$ \\
\hline Toluene (ug/L) & $<5$ & $<5$ \\
\hline trans-1,2-DCE (ug/L) & $<5$ & $<5$ \\
\hline TCE (ug/L) & $<1$ & $<1$ \\
\hline $\mathrm{VC}^{4}(\mathrm{ug} / \mathrm{L})$ & $<3$ & $<3$ \\
\hline Xylene (ug/L) & $<5$ & $<5$ \\
\hline Tc-99 (pCi/L) & $<25$ & $<25$ \\
\hline $\mathrm{DOC}(\mathrm{mg} / \mathrm{L})$ & $<1$ & $<1$ \\
\hline Total Iron ${ }^{2}(\mathrm{mg} /)$ & 0.1 & 0.6 \\
\hline Ferrous Iron ${ }^{2}(\mathrm{mg} / \mathrm{L})$ & 0.1 & 0.1 \\
\hline Ferric iron (mg/L) & 0 & 0.5 \\
\hline Alkalinity $^{3}(\mathrm{mg} / \mathrm{L})$ & 124 & 104 \\
\hline Chloride (mg/L) & 3 & 20 \\
\hline Nitrate (mg/L) & $<0.5$ & 6.3 \\
\hline Ammonia $^{2}(\mathrm{mg} / \mathrm{L})$ & $<0.1$ & $<0.1$ \\
\hline Sulfate (mg/L) & 5.5 & 7 \\
\hline Hydrogen Sulfide $(\mathrm{mg} / \mathrm{L})$ & $<0.01$ & $<0.01$ \\
\hline${ }^{13} \mathrm{C}$ of TCE (per mil) & ND & ND \\
\hline${ }^{13} \mathrm{C}$ of DIC (per mil) & -18.4 & -16.5 \\
\hline${ }^{37} \mathrm{Cl}$ of TCE (per mil SMOC) & NA & NA \\
\hline${ }^{37} \mathrm{Cl}$ of inorganic $\mathrm{Cl}$ (per mil) & NA & 1.1 \\
\hline $\mathrm{O}^{18} / \mathrm{O}^{16}(\mathrm{SMOW})$ & -4.9 & -5.8 \\
\hline
\end{tabular}


- Result Inferred by Subtracting Ferrous Iron from Total Iron

'Extracted Gas Analysis

${ }^{2}$ Field Measured

${ }^{3}$ Total Alkalinity as bicarbonate

${ }^{4}$ Purge-and-Trap GC analysis using an ELCD detector by CDM

ND - not detected

NA - not analyzed

$\mathrm{E}$ - error in analysis, not enough sample for reanalysis. 


\begin{tabular}{|c|c|c|}
\hline Analyte & MW187 (UCRS) & MW157 (UCRS) \\
\hline Sample Number & $5378-97$ & $5377-97$ \\
\hline Depth to Water ${ }^{2}(\mathrm{ft})$ & 30.50 & 38.74 \\
\hline Specific Conductance ${ }^{2}$ (umhos $/ \mathrm{cm}$ ) & 873 & 460 \\
\hline Dissolved Oxygen ${ }^{2}(\mathrm{mg} / \mathrm{L})$ & $\overline{1.1}$ & 10.1 \\
\hline Dissolved Oxygen ${ }^{1}$ (mg/L) & 1.0 & 7.6 \\
\hline Temperature ${ }^{2}\left({ }^{\circ} \mathrm{C}\right)$ & $\overline{14}$ & 17 \\
\hline $\mathrm{pH}^{2}$ (units) & 6.2 & 6.8 \\
\hline $\mathrm{Eh}^{2}(\mathrm{mv})$ & +180 & +380 \\
\hline Hydrogen 1 (nM) & $<0.22$ & $<0.22$ \\
\hline Methane $^{1}(\mathrm{mg} / \mathrm{L})$ & $<0.001$ & $<0.001$ \\
\hline Nitrogen ${ }^{1}(\mathrm{ppm})$ & 27.5 & 22.1 \\
\hline $\operatorname{Argon}^{1}(\mathrm{ppm})$ & 0.9 & 0.7 \\
\hline Ethylene (ug/L) & $<30$ & $<30$ \\
\hline Ethane (ug/L) & $<30$ & $<30$ \\
\hline $1,1,1-\mathrm{TCA}(\mathrm{ug} / \mathrm{L})$ & $<25$ & $<12,500$ \\
\hline $1,1,1-\mathrm{TCA}$ (ug/L) & $<25$ & $<12,500$ \\
\hline $1,1-\mathrm{DCA}(\mathrm{ug} / \mathrm{L})$ & $<25$ & $<12,500$ \\
\hline 1,1-DCE (ug/L) & $<25$ & $<12,500$ \\
\hline $1,2-\mathrm{DCE}(\mathrm{ug} / \mathrm{L})$ & $<25$ & $<12,500$ \\
\hline Benzene (ug/L) & $<25$ & $<12,500$ \\
\hline Bromodichloromethane (ug/L) & $<25$ & $<12,500$ \\
\hline Carbon Tetrachloride (ug/L) & $<25$ & $<12,500$ \\
\hline Chloroethane (ug/L) & $<25$ & $<12,500$ \\
\hline cis-1,2-DCE (ug/L) & 84 & 130 \\
\hline Ethylbenzene (ug/L) & $<25$ & $<12,500$ \\
\hline PCE (ug/L) & $<25$ & $<12,500$ \\
\hline Toluene (ug/L) & $<25$ & $<12,500$ \\
\hline trans-1,2-DCE (ug/L) & $<25$ & $<12,500$ \\
\hline $\mathrm{TCE}$ (ug/L) & 490 & 180000 \\
\hline $\mathrm{VC}^{4}(\mathrm{ug} / \mathrm{L})$ & $<3$ & $<3$ \\
\hline Xylene (ug/L) & $<5$ & $<12,500$ \\
\hline Tc-99 (pCi/L) & $<25$ & NA \\
\hline $\mathrm{DOC}(\mathrm{mg} / \mathrm{L})$ & 4 & 2 \\
\hline Total Iron ${ }^{2}(\mathrm{mg} / \mathrm{L})$ & 5 & 1.2 \\
\hline Ferrous Iron ${ }^{2}(\mathrm{mg} / \mathrm{L})$ & 0.2 & $<0.1$ \\
\hline Ferric Iron (mg/L) & 4.8 & 1.2 \\
\hline Alkalinity $^{3}(\mathrm{mg} / \mathrm{L})$ & 351 & 99 \\
\hline Chloride (mg/L) & 120 & 30 \\
\hline Nitrate (mg/L) & $<0.5$ & $<0.5$ \\
\hline $\operatorname{Ammonia}^{2}(\mathrm{mg} / \mathrm{L})$ & $<0.1$ & $<0.1$ \\
\hline Sulfate (mg/L) & 15 & 115 \\
\hline Hydrogen Sulfide ${ }^{2}(\mathrm{mg} / \mathrm{L})$ & $<0.01$ & $<0.01$ \\
\hline${ }^{13} \mathrm{C}$ of TCE (per mil) & -28.6 & -27.8 \\
\hline${ }^{13} \mathrm{C}$ of DIC (per mil) & -19.4 & -12.0 \\
\hline${ }^{37} \mathrm{Cl}$ of TCE (per mil SMOC) & $\mathrm{E}$ & -1.0 \\
\hline${ }^{37} \mathrm{Cl}$ of inorganic $\mathrm{Cl}$ (per mil) & 0.7 & 0.3 \\
\hline $\mathrm{O}^{18} / \mathrm{O}^{16}$ (SMOW) & -5.4 & $\overline{-5.3}$ \\
\hline
\end{tabular}

* Result Inferred by Subtracting Ferrous Iron from Total Iron 
1 Extracted Gas Analysis

2 Field Measured

${ }^{3}$ Total Alkalinity as bicarbonate

${ }^{4}$ Purge-and-Trap GC analysis using an ELCD by CDM

ND - not detected

NA - not analyzed

$\mathrm{E}$ - error in analysis, not enough sample for reanalysis. 


\begin{tabular}{|c|c|c|c|c|c|c|}
\hline Analyte & $\begin{array}{c}\text { MW262 } \\
\text { (RGA) NW } \\
\end{array}$ & \begin{tabular}{|c|} 
MW262 Dup. \\
(RGA) NW
\end{tabular} & $\begin{array}{c}\text { MW66 } \\
\text { (RGA) NW }\end{array}$ & $\begin{array}{c}\text { MW248 } \\
\text { (RGA) NW } \\
\end{array}$ & $\begin{array}{c}\text { MW233 } \\
\text { (RGA)NW } \\
\end{array}$ & \begin{tabular}{|c|} 
MW146 \\
$(\mathrm{RGA}) \mathrm{NW}$ \\
\end{tabular} \\
\hline Sample Number & $5384-97$ & $5385-97$ & $5370-97$ & $5382-97$ & $5381-97$ & $5375-97$ \\
\hline Depth to Water ${ }^{2}(\mathrm{ft})$ & 40.23 & 40.23 & 37.96 & 35.16 & 39.36 & 28.30 \\
\hline Specific Conductance (umhos $/ \mathrm{cm}$ ) & 523 & 523 & 381 & 377 & 289 & 338 \\
\hline Dissolved Oxygen ${ }^{2}(\mathrm{mg} / \mathrm{L})$ & 3.8 & 3.8 & 7.0 & 4.5 & 5.5 & 5.5 \\
\hline Dissolved Oxygen ${ }^{1}$ (ppm) & 4.3 & 4.4 & 7.9 & 4.7 & 5.9 & 5.9 \\
\hline Temperature ${ }^{2}\left({ }^{\circ} \mathrm{C}\right)$ & 16 & 16 & 15 & 15 & 15 & 17 \\
\hline $\mathrm{pH}^{2}$ (units) & 5.7 & 5.7 & 5.7 & 5.7 & 6.0 & 6.0 \\
\hline $\mathrm{Eh}^{2}(\mathrm{mv})$ & +220 & +180 & +280 & +160 & +170 & +160 \\
\hline Hydrogen' (nM) & $<0.22$ & $<0.22$ & $<0.22$ & $<0.22$ & $<0.22$ & $<0.22$ \\
\hline Methane $(\mathrm{ppm})$ & $<0.001$ & $<0.001$ & $<0.001$ & $<0.001$ & $<0.001$ & $<0.001$ \\
\hline Nitrogen $^{1}(\mathrm{ppm})$ & 25.5 & 25.6 & 31.0 & 26.1 & 25.5 & 26.1 \\
\hline Argon ${ }^{1}(\mathrm{ppm})$ & 0.7 & 0.7 & 0.9 & 0.9 & 0.9 & 0.9 \\
\hline Ethane (ug/L) & $<30$ & $<30$ & $<30$ & $<30$ & $<30$ & $<30$ \\
\hline Ethene (ug/L) & $<30$ & $<30$ & $<30$ & $<30$ & $<30$ & $<30$ \\
\hline $1,1,1-\mathrm{TCA}(\mathrm{ug} / \mathrm{L})$ & $<1250$ & $<1250$ & $<1250$ & $<1250$ & $<10$ & $<5$ \\
\hline $1,1,1-\mathrm{TCA}$ (ug/) & $<1250$ & $<1250$ & $<1250$ & $<1250$ & $<10$ & $<5$ \\
\hline $1,1-\mathrm{DCA}(\mathrm{ug} / \mathrm{L})$ & $<1250$ & $<1250$ & $<1250$ & $<1250$ & $<10$ & $<5$ \\
\hline $1,1-\mathrm{DCE}$ (ug/L) & $<1250$ & $<1250$ & $<1250$ & $<1250$ & $<10$ & $<5$ \\
\hline 1,2-DCE (ug/L) & $<1250$ & $<1250$ & $<1250$ & $<1250$ & $<10$ & $<5$ \\
\hline Benzene (ug/L) & $<1250$ & $<1250$ & $<1250$ & $<1250$ & $<10$ & $<5$ \\
\hline Bromodichloromethane (ug/L) & $<1250$ & $<1250$ & $<1250$ & $<1250$ & $<10$ & $<5$ \\
\hline Carbon Tetrachloride (ug/L) & $<1250$ & $<1250$ & $<1250$ & $<1250$ & $<10$ & $<5$ \\
\hline Chloroethane (ug/L) & $<1250$ & $<1250$ & $<1250$ & $<1250$ & $<10$ & $<5$ \\
\hline cis-1,2-DCE $(\mathrm{ug} / \mathrm{L})$ & 58 & 29 & 58 & $<\mathrm{I}$ & $<1$ & $<1$ \\
\hline Ethylbenzene (ug/L) & $<1250$ & $<1250$ & $<1250$ & $<1250$ & $<10$ & $<5$ \\
\hline PCE (ug/L) & $<1250$ & $<1250$ & $<1250$ & $<1250$ & $<10$ & $<5$ \\
\hline Toluene (ug/L) & $<1250$ & $<1250$ & $<1250$ & $<1250$ & $<10$ & $<5$ \\
\hline trans-1,2-DCE (ug/L) & $<1250$ & $<1250$ & $<1250$ & $<1250$ & $<10$ & $<5$ \\
\hline $\mathrm{TCE}$ (ug/L) & 16000 & 16000 & 13000 & 12000 & 150 & 1 \\
\hline $\mathrm{VC}^{4}$ (ug/L) & $<3$ & $<3$ & $<3$ & $<3$ & $<3$ & $<3$ \\
\hline Xylene (ug/L) & $<1250$ & $<1250$ & $<1250$ & $<1250$ & $<10$ & $<5$ \\
\hline $\mathrm{Tc}-99(\mathrm{pCi} / \mathrm{L})$ & $4056+-58$ & $4178+-59$ & $2911+-51$ & $2601+-48$ & $98+-14$ & $<25$ \\
\hline DOC (mg/L) & $<1$ & 1 & $<1$ & 1 & 1 & 2 \\
\hline Total Iron ${ }^{2}(\mathrm{mg} / \mathrm{L})$ & 1.5 & 1.2 & $<0.3$ & 0.8 & 0.6 & 0.6 \\
\hline Ferrous Iron ${ }^{2}(\mathrm{mg} / \mathrm{L})$ & $<0.1$ & $<0.1$ & NA & $<0.1$ & 0.1 & $<0.1$ \\
\hline Ferric Iron (mg/L) & 1.5 & 1.2 & NA & 0.8 & 0.5 & 0.6 \\
\hline Alkalinity $^{3}(\mathrm{mg} / \mathrm{L})$ & 128 & 126 & 106 & 102 & 124 & 125 \\
\hline Chloride (mg/L) & 70 & 70 & 50 & 50 & 25 & 30 \\
\hline Nitrate (mg/L) & 50 & 50 & 35 & 30 & 7.5 & 15 \\
\hline Ammonia $^{2}(\mathrm{mg} / \mathrm{L})$ & $<0.1$ & $<0.1$ & $<0.1$ & $<0.1$ & $<0.1$ & $<0.1$ \\
\hline Sulfate $(\mathrm{mg} / \mathrm{L})$ & 10 & 10 & 10 & 10 & 15 & 8.8 \\
\hline Hydrogen Sulfide ${ }^{2}(\mathrm{mg} / \mathrm{L})$ & $<0.01$ & $<0.01$ & $<0.01$ & $<0.01$ & 0.02 & $<0.01$ \\
\hline${ }^{13} \mathrm{C}$ of TCE (per mil) & -27.3 & -26.8 & -27.6 & -26.7 & $\mathrm{ND}$ & ND \\
\hline${ }^{13} \mathrm{C}$ of DIC (per mil) & -18.5 & -18.5 & -17.9 & -15.4 & -16.7 & -17.9 \\
\hline${ }^{37} \mathrm{Cl}$ of TCE (per mil SMOC) & 0.2 & -0.5 & 0.6 & 0.4 & 1.6 & $\mathrm{NA}$ \\
\hline${ }^{37} \mathrm{Cl}$ of inorganic $\mathrm{Cl}$ (per mil) & 0.7 & 0.7 & 0.9 & 0.8 & 1.1 & 0.8 \\
\hline $\mathrm{O}^{18} / \mathrm{O}^{16}(\mathrm{SMOW})$ & -5.2 & -5.6 & -5.4 & -5.6 & -5.8 & -5.8 \\
\hline
\end{tabular}


* Result Inferred by Subtracting Ferrous Iron from Total Iron ${ }^{1}$ Extracted Gas Analysis

2 Field Measured

${ }^{3}$ Total Alkalinity as bicarbonate

${ }^{4}$ Purge-and-Trap $G C$ analysis using an ELCD by CDM

ND - not detected

NA - not analyzed

$\mathrm{E}$ - error in analysis, not enough sample for reanalysis. 


\begin{tabular}{|c|c|c|c|c|c|c|}
\hline Analyte & \begin{tabular}{|c|} 
MW155 \\
(RGA) NE \\
\end{tabular} & $\begin{array}{c}\text { MW108 } \\
\text { (RGA) NE }\end{array}$ & $\begin{array}{c}\text { MW255 } \\
\text { (RGA) NE }\end{array}$ & $\begin{array}{c}\text { MW124 } \\
\text { (RGA) NE }\end{array}$ & $\begin{array}{c}\text { MW193 } \\
\text { (RGA) NE }\end{array}$ & $\begin{array}{c}\text { MW100 } \\
\text { (RGA) NE }\end{array}$ \\
\hline Sample Number & $5376-97$ & $5373-97$ & $5383-97$ & $5374-97$ & $5379-97$ & $5371-97$ \\
\hline Depth to Water ${ }^{2}(\mathrm{ft})$ & 47.46 & 51.93 & 50.29 & 32.74 & 35.16 & 41.76 \\
\hline Specific Conductance ${ }^{2}$ (umhos $/ \mathrm{cm}$ ) & 494 & 491 & 660 & 446 & 319 & 412 \\
\hline Dissolved Oxygen ${ }^{2}(\mathrm{mg} / \mathrm{L})$ & 4.4 & 4.1 & 0.65 & 3.0 & 2.3 & 6.2 \\
\hline Dissolved Oxygen ${ }^{1}$ (ppm) & 5.6 & 4.0 & 1.0 & 3.3 & 3.6 & 5.6 \\
\hline Temperature $e^{2}\left({ }^{\circ} \mathrm{C}\right)$ & 18 & 18 & 17 & 16 & 17 & 18 \\
\hline $\mathrm{pH}^{2}$ (units) & 5.9 & 6.0 & 6.0 & 5.8 & 6.3 & 5.9 \\
\hline $\mathrm{Eh}^{2}(\mathrm{mv})$ & +200 & +460 & +190 & +120 & +160 & +190 \\
\hline Hydrogen ${ }^{1}$ (nM) & $<0.22$ & $<0.22$ & $<0.22$ & $<0.22$ & $<0.22$ & $<0.22$ \\
\hline Methane $(\mathrm{ppm})$ & $<0.001$ & $<0.001$ & $<0.001$ & $<0.001$ & $<0.001$ & $<0.001$ \\
\hline Nitrogen $^{1}(\mathrm{ppm})$ & 26.6 & 25.3 & 29.3 & 27.1 & 26.4 & 27.6 \\
\hline Argon $^{2}(\mathrm{ppm})$ & 0.9 & 0.7 & 1.1 & 0.9 & 0.9 & 0.9 \\
\hline Ethane (ug/L) & $<30$ & $<30$ & $<30$ & $<30$ & $<30$ & $<30$ \\
\hline Ethene (ug/L) & $<30$ & $<30$ & $<30$ & $<30$ & $<30$ & $<30$ \\
\hline $1,1,1-\mathrm{TCA}$ (ug/L) & $<100$ & $<250$ & $<125$ & $<100$ & $<5$ & $<5$ \\
\hline $1,1,1-$ TCA (ug/L) & $<100$ & $<250$ & $<125$ & $<100$ & $<5$ & $<5$ \\
\hline $1,1-\mathrm{DCA}(\mathrm{ug} / \mathrm{L})$ & $<100$ & $<250$ & $<125$ & $<100$ & $<5$ & $<5$ \\
\hline $1,1-\mathrm{DCE}$ (ug/L) & $<100$ & $<250$ & $<125$ & $<100$ & $<5$ & $<5$ \\
\hline 1,2-DCE (ug/L) & $<100$ & $<250$ & $<125$ & $<100$ & $<5$ & $<5$ \\
\hline Benzene (ug/L) & $<100$ & $<250$ & $<125$ & $<100$ & $<5$ & $<5$ \\
\hline Bromodichloromethane (ug/L) & $<100$ & $<250$ & $<125$ & $<100$ & $<5$ & $<5$ \\
\hline Carbon Tetrachloride (ug/L) & $<100$ & $<250$ & $<125$ & $<100$ & $<5$ & $<5$ \\
\hline Chloroethane (ug/L) & $<100$ & $<250$ & $<125$ & $<100$ & $<5$ & $<5$ \\
\hline cis-1,2-DCE $(\mathrm{ug} / \mathrm{L})$ & 7 & 21 & 10 & 3 & $<1$ & 2 \\
\hline Ethylbenzene (ug/L) & $<100$ & $<250$ & $<125$ & $<100$ & $<5$ & $<5$ \\
\hline$\overline{\mathrm{PCE}}$ (ug/L) & $<100$ & $<250$ & $<125$ & $<100$ & $<5$ & $<5$ \\
\hline Toluene (ug/L) & $<100$ & $<250$ & $<125$ & $<100$ & $<5$ & $<5$ \\
\hline $\operatorname{trans-1,2-DCE}(\mathrm{ug} / \mathrm{L})$ & $<100$ & $<250$ & $<125$ & $<100$ & $<5$ & $<5$ \\
\hline TCE (ug/L) & 700 & 950 & 1300 & 1100 & 4 & $<1$ \\
\hline $\mathrm{VC}^{4}$ (ug/L) & $<3$ & $<3$ & $<3$ & $<3$ & $<3$ & $<3$ \\
\hline Xylene (ug/L) & $<100$ & $<250$ & $<125$ & $<100$ & $<5$ & $<5$ \\
\hline Tc-99 (pCi/L) & $682+-26$ & $\mathrm{NA}$ & $<25$ & $<25$ & $<25$ & $<25$ \\
\hline $\mathrm{DOC}(\mathrm{mg} / \mathrm{L})$ & $\mathrm{E}$ & 2 & 1 & 6 & 2 & 2 \\
\hline Total Iron $(\mathrm{mg} / \mathrm{L})$ & 0.7 & 3.2 & 0.4 & 1.2 & 0.9 & 0.9 \\
\hline Ferrous Iron ${ }^{2}(\mathrm{mg} / \mathrm{L})$ & $<0.1$ & 0.1 & $<0.1$ & $<0.1$ & $<0.1$ & $<0.1$ \\
\hline Ferric Iron (mg/L) & 0.7 & 3.1 & 0.4 & 1.2 & 0.9 & 0.9 \\
\hline Alkalinity $^{3}(\mathrm{mg} / \mathrm{L})$ & 139 & 150 & 223 & 130 & 178 & 125 \\
\hline Chloride (mg/L) & $\overline{85}$ & 60 & 90 & 70 & 20 & 50 \\
\hline Nitrate $(\mathrm{mg} / \mathrm{L})$ & 9 & 9.3 & 6.8 & 6.1 & 0.7 & 20 \\
\hline Ammonia $^{2}(\mathrm{mg})$ & $<0.1$ & $<0.1$ & 0.1 & $<0.1$ & $<0.1$ & $<0.1$ \\
\hline Sulfate (mg/L) & 10 & 25 & 30 & 10 & 9.5 & 7.9 \\
\hline Hydrogen Sulfide $(\mathrm{mg} / \mathrm{L})$ & $<0.01$ & $<0.01$ & $<0.01$ & 0.04 & $<0.01$ & $<0.01$ \\
\hline${ }^{13} \mathrm{C}$ of TCE (per mil) & -27.5 & -28.3 & -29.4 & -30.4 & $\mathrm{ND}$ & ND \\
\hline${ }^{13} \mathrm{C}$ of DIC (per mil) & -16.8 & -17.9 & -18.2 & -20.0 & -19.8 & -19.1 \\
\hline${ }^{37} \mathrm{Cl}$ of TCE (per mil SMOC) & 1.6 & 1.5 & NA & 2.0 & 1.6 & $\overline{\mathrm{NA}}$ \\
\hline${ }^{37} \mathrm{Cl}$ of inorganic $\mathrm{Cl}$ (per mil) & 1.0 & 0.8 & NA & $1.3 / 1.4$ & 0.9 & 1.1 \\
\hline $\mathrm{O}^{18} / \mathrm{O}^{16}$ (SMOW) & -5.5 & -5.5 & -5.5 & -5.3 & -5.8 & -5.6 \\
\hline
\end{tabular}


* Result Inferred by Subtracting Ferrous Iron from Total Iron

${ }^{1}$ Extracted Gas Analysis

${ }^{2}$ Field Measured

${ }^{3}$ Total Alkalinity as bicarbonate

${ }^{4}$ Purge-and-Trap GC analysis using an ELCD by CDM

ND - not detected

NA - not analyzed

E - error in analysis, not enough sample for reanalysis: 
APPENDIX B

HISTORICAL MONITORING WELL DATA 
Environmental Information Management System

Data Summary for Sampling Station MW100 04/28/97

\begin{tabular}{|c|c|c|c|c|c|c|c|}
\hline Analysis & & (Units) & Maximum & n Minimu & & Average & Count \\
\hline Alkalinity & $(\mathrm{mg} / \mathrm{L})$ & 88.00 & 88.000 & 88.00 & 0000 & $\mathbf{I}$ & \\
\hline Chloride & $(\mathrm{mg} / \mathrm{L})$ & 47.7000 & 47.7000 & 47.7000 & 1 & & \\
\hline Nitrate as Nitrogen & $(m g / L)$ & 5.4000 & 5.4000 & 5.4000 & 1 & & \\
\hline Sulfate & $(\mathrm{mg} / \mathrm{L})$ & 8.5000 & 8.5000 & 8.5000 & j & & \\
\hline Total Organic Carbon & $(m g / L)$ & 1.0000 & 1.0000 & 1.0000 & i & & \\
\hline Silica & & $(\mathrm{mg} / \mathrm{L})$ & 180000 & 18.0000 & & 18.0000 & 1 \\
\hline Arsenic & $(m g / L)$ & $<0.0050<$ & $<0.0050<$ & 0.0050 & 1 & & \\
\hline Selenium & $(m g / L)$ & $<0.0050<$ & $<0.0050<$ & $=0.0050$ & 1 & & \\
\hline Aluminum & $(\mathrm{mgh})$ & 2.1500 & 2.1500 & 2.1500 & 1 & & \\
\hline Antimony & $(\mathrm{mg} / \mathrm{L})$ & $<0.2500<$ & $<0.2500<$ & 0.2500 & i & & \\
\hline Barium & $(\mathrm{mg} / \mathrm{L})$ & 0.1730 & 0.1730 & 0.1730 & 1 & & \\
\hline Beryllium & $(m g / L)$ & $<0.0250<$ & $<0.0250<$ & 0.0250 & i & & \\
\hline Cadmium & $(m g / L)$ & $<0.1000<$ & $<0.1000<$ & 0.1000 & $\mathbf{I}$ & & \\
\hline Calcium & $(\mathrm{mgl})$ & 21.4000 & 21.4000 & 21.4000 & 1 & & \\
\hline Cobalt & $(\mathrm{mg} / \mathrm{L})$ & $<0.1000<$ & $<0.1000<$ & 0.1000 & $\mathbf{I}$ & & \\
\hline Copper & $(\mathrm{mg} / \mathrm{L})$ & $<0.1000<$ & $<0.1000<$ & 0.1000 & i & & \\
\hline Iron & & $(m g / L)$ & 5.7800 & 5.7800 & & 5.7800 & 1 \\
\hline Magnesium & $(\mathrm{mg} / \mathrm{L})$ & 8.7700 & 8.7700 & 8.7700 & 1 & & \\
\hline Manganese & $(\mathrm{mg} / \mathrm{L})$ & 0.1040 & 0.1040 & 0.1040 & 1 & & \\
\hline Molybdenum & $(\mathrm{mg} / \mathrm{L})$ & $<0.1000<$ & $<0.1000<$ & 0.1000 & 1 & & \\
\hline Nickel & $(\mathrm{mg} / \mathrm{L})$ & $<0.1000<$ & $<0.1000<$ & 0.1000 & $i$ & & \\
\hline Polassium & $(\mathrm{mg} / \mathrm{L})$ & 5.0000 & 5.0000 & 5.0000 & 1 & & \\
\hline Silver & & $(\mathrm{mg} / \mathrm{L})$ & $<0.0500$ & $<0.0500$ & $00<$ & $=0.0500$ & 01 \\
\hline Sodium & $(\mathrm{mg} / \mathrm{L})$ & 37.1000 & 37.1000 & 37.1000 & 1 & & \\
\hline Zinc & & $(\mathrm{mg} / \mathrm{L})$ & $<0.2500$ & $<0.250$ & $00<$ & $=0.2500$ & 1 \\
\hline Barium, Dissolved & $(\mathrm{mg} / \mathrm{L})$ & 0.1580 & 0.1580 & 0.1580 & 1 & & \\
\hline Depth to Water & (Feet) & 42.1000 & 42.1000 & 42.1000 & $t$ & & \\
\hline Dissolved Oxygen & $(\mathrm{mg} / \mathrm{L})$ & 6.6300 & 6.6300 & 6.6300 & $i$ & & \\
\hline Dissolved Solids & $(m g / L)$ & 228,0000 & 228.0000 & 228.0000 & 1 & & \\
\hline $\mathrm{pH}$ & & (SU) & 5.9000 & 5.9000 & & 5.9000 & 1 \\
\hline Specific conductance & (umhos' & cm) 386.0000 & $0 \quad 386.0000$ & $0 \quad 386.000$ & 200 & 1 & \\
\hline Temperature & (F) & 62.0000 & 62.0000 & 62.0000 & 1 & & \\
\hline Total Suspended Solids & $(\mathrm{mg} / \mathrm{L})$ & 49.0000 & 49.0000 & 49.0000 & 1 & & \\
\hline Gross Alpha & $(\mathrm{pCi} / \mathrm{L})$ & 2.2000 & 2.2000 & $2.2000 \quad 1$ & 1 & & \\
\hline Gross Beta & $(\mathrm{OCi} / \mathrm{L})$ & 0.0000 & -1.0000 & -1.0000 & 1 & & \\
\hline Radon 222 & $(\mathrm{pCi} / \mathrm{L})$ & 329.0000 & $329.0000 \quad 3$ & 329.0000 & 1 & & \\
\hline Technetium-99 & $(\mathrm{oCi} / \mathrm{L})$ & 17.0000 & 17.0000 & 17.0000 & $i$ & & \\
\hline Uranium & $(\mathrm{mg} / \mathrm{L})$ & $<0.0010<$ & $0.0010<$ & 0.0010 & 1 & & \\
\hline 1,1,1-Trichloroethane & $(u g / L)$ & $<5.0000<$ & $5.0000<$ & 5.0000 & $i$ & & \\
\hline 1,1,2-Trichloroethane & (ug/L) & $<5.0000<$ & $5.0000<$ & 5.0000 & 1 & & \\
\hline 1,1-Dichloroeahane & $(u g / L)$ & $<5.0000<$ & $5.0000<$ & 5.0000 & 1 & & \\
\hline 1,1-Dichloroethere & $(4 g / L)$ & $<5.0000<$ & $5.0000<$ & 5.0000 & 1 & & \\
\hline 1,2-Dichloroethane & $(u g / L)$ & $<5.0000<$ & $5.0000<$ & 5.0000 & l & & \\
\hline Benzene & $(u g / L)$ & $<5.0000<$ & $5.0000<$ & 5.0000 & $\mathbf{l}$ & & \\
\hline Bromodichloromethane & $(u g / L)<$ & $5.0000<5$ & $5.0000<5$. & $5.0000 \quad 1$ & & & \\
\hline Cabbon Tetrachloride & $(u g / L)$ & $<5.0000<$ & $5.0000<$ & 5.0000 & 1 & & \\
\hline Chloroethare & $(u \in / L)$ & $<5.0000<$ & $5,0000<$ & 5.0000 & $i$ & & \\
\hline Chloroform & $(u g / L)$ & $<5.0000<$ & $5.0000<$ & 5.0000 & $i$ & & \\
\hline cis-1,2-dichloroethere & $(u g / L)$ & $<5.0000<$ & $5.0000<$ & 5.0000 & l & & \\
\hline Ethane & $(u g / L)$ & $<30.000<$ & $30.0000<$ & 30.000 & $i$ & & \\
\hline Ethene & (ug/L) & $<30.000<$ & $30.0000<$ & 30.000 & 1 & & \\
\hline Ethylbenzene & $(\mathrm{ug} / \mathrm{L})$ & $<5.0000<$ & $5.0000<$ & 5.0000 & l & & \\
\hline Tetrachlonoethene & (ug/L) & $<5.0000<$ & $5.0000<$ & 5.0000 & 1 & & \\
\hline Toluene & $(u g / L)$ & $<5.0000<$ & $5.0000<$ & 5,0000 & 1 & & \\
\hline Trans-1,2-Dichloroethen & (ug/L) & $<5.0000<$ & $<5.0000<$ & 5.0000 & 1 & & \\
\hline Trichloroethene & $(4 \mathrm{~g} / \mathrm{L})$ & $3.0000<$ & $1.0000<$ & 1.2857 & $i$ & & \\
\hline Vinyl Chloride & $(\omega g / L)$ & $<5.0000<$ & < $5.0000<$ & 5.0000 & 1 & & \\
\hline Xylene & $(u g / L)$ & $<5.0000<$ & $5.0000<$ & 5.0000 & i & & \\
\hline
\end{tabular}


Aralysis (Units) Maximum Minimum Average Count

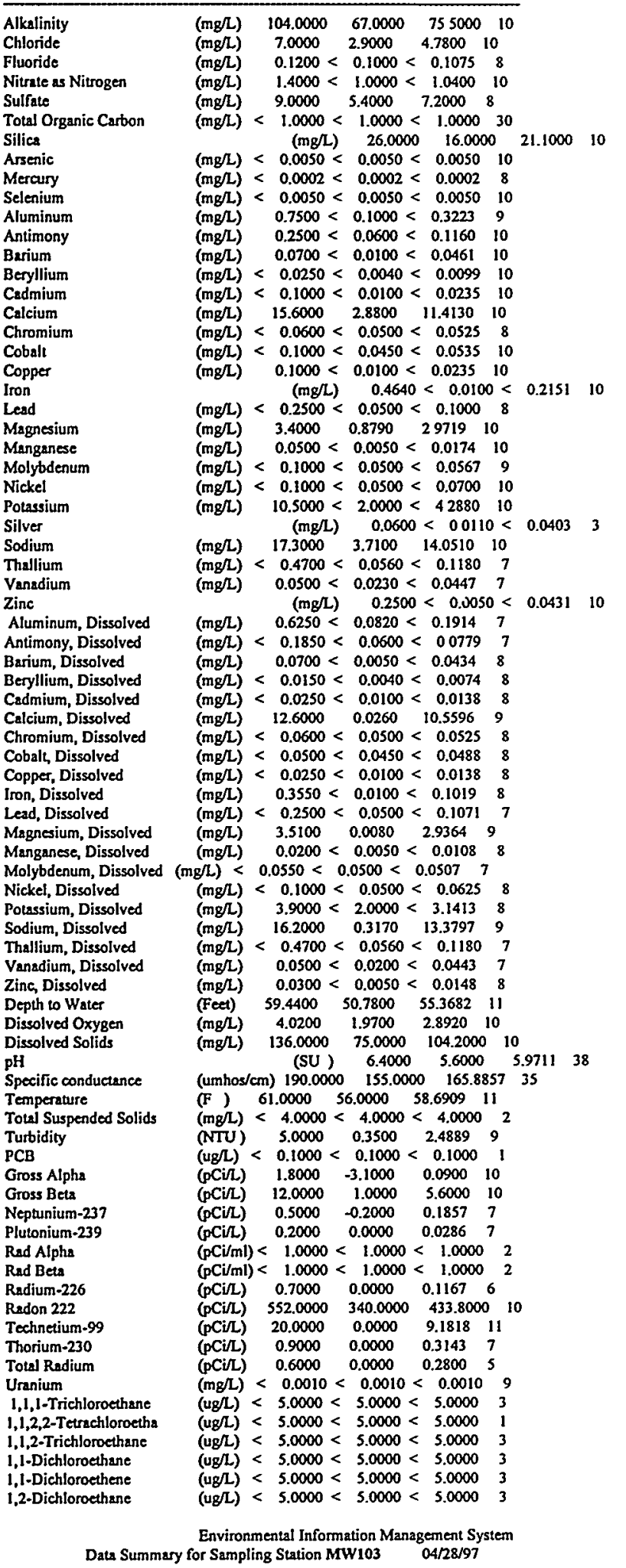

Analysis

(Units) Maximum Minimum Average Count 
1,2-Dichloropropane

2-Butanone

2-Hexanone

1-Methyl-2-pentanone

Acetone

Bromodichloromethane

Bromoform

Bromomethane

Carbon Disulfide

Carbon Tetrachloride

Chlorobenzene

Chloroethane

Chloroform

Chloromethane

cis-1,2-dichloroethene

cis-1,3-Dichloropropene

Dibromochloromethere

Ethylbenzene

Methylene Chloride

Styrene

Tetrachloroethene

Toluene

Trans-1,2-Dichloroethen trans-1,3-Dichloroprope

Trichloroethene

Vinyl Acetate

Vinyl Chloride

Xylene $(\mathrm{ug} / \mathrm{L})<5.0000<5.0000<5.00001$

(ug/L) $<100.0000<100.0000<100.0000$

$(u g / L)<50.0000<50.0000<50.0000$

(ug/L) $<50.0000<50.0000<50.00001$

$(\mathrm{ug} / \mathrm{L})<100.0000<100.0000<100.0000$

$(\mathrm{ug} / \mathrm{L})<5.0000<5.0000<5.0000$

(ugL) $<5.0000<5.0$

$(\mathrm{ug} / \mathrm{L})<5.0000<5.0000<5.00001$

$(u \mathrm{u} / \mathrm{L})<10.0000<10.0000<10.00001$

$(\mathrm{ug} / \mathrm{L})<100.0000<100.0000<100.0000$

(ug/L) $<5.0000<5.0000<5.00003$

$($ ug $/ \mathrm{L})<5.0000<5.0000<5.0000$

(ug/L) $<10.0000<10.0000<10.0000$

$(\mathrm{ug} / \mathrm{L})<5.0000<5.0000<5.00003$

$(\mathrm{ug} / \mathrm{L})<10.0000<10.0000<10.0000$

$(\mathrm{ug} / \mathrm{L})<5.0000<5.0000<5.00002$

$(\mathrm{ug} / \mathrm{L})<5.0000<5.0000<5.0000$

$(\mu / L)<5.0000<5.0000<5.00001$

$(\mathrm{ug} / \mathrm{L})<5.0000<5.0000<5.00003$

(ug/L) $<5.0000<5.0000<5.0000<1$

(ug/L) $<5.0000<5.0000<5.0000$

$(\mathrm{ug} / \mathrm{L})<5.0000<5.0000<5.0000$

(ug/L) $<5.0000<5.0000<5.0000$

$(\mathrm{ug} / \mathrm{L})<5.0000<5.0000<5.0000$

(ug/L) $<5.0000<1.0000<1.44449$

$(\mathrm{ug} / \mathrm{L})<50.0000<50.0000<50.0000$

$(u g L)<10.0000<5.0000<8.33333$

$(\mathrm{ug} / \mathrm{L})<10.0000<5.0000<6.66673$ 
Analysis

Aluminum

Chromium

Copper

Iron

Nickel

Zinc

Depth to Water

Dissolved Oxygen

$\mathrm{pH}$

Specific conductance

Temperature

Turbidity

Tochnetium-99

Uranium

1,1,1-Trichloroethane

1,1,2-Trichloroethane

1,1-Dichloroethane

1,1-Dichloroethene

1,2-Dichloroethane

Benzene

Bromodichloromethane

Carbon Tetrachloride

Chloroform

eis-1,2-dichloroethene

Ethylbenzene

Tetrachloroethene

Toluene

Trans-1,2-Dichloroethen

Trichloroethene

Vinyl Chloride

Xylene

(Units) Maximum Minimum Average Count

$\begin{array}{lllll}(\mathrm{mg} / \mathrm{L}) & 0.1780 & 0.1290 & 0.1482 & 5\end{array}$

(mg/L) $<0.0500<0.0500<0.05005$

(mg/L) $0.0180<0.0100<0.0116$ s

(mg/L) $0.0840<0.0100<0.0320$

(mg/L) $<0.0500<0.0500<0.05005$

$\begin{array}{lllll}(\mathrm{mg} / \mathrm{L}) & 0.2120 & 0.0720 & 0.1204 & 5\end{array}$

$\begin{array}{lllll}\text { (Feet) } \quad 55.2700 & 55.2100 & 55.2200 & 6\end{array}$

$\begin{array}{lllll}(\mathrm{mg} / \mathrm{L}) & 6.2100 & 3.5600 & 4.6233 & 6\end{array}$

$\begin{array}{lllll}\text { (SU ) } & 9.7000 & 5.9000 & 6.3579 & 19\end{array}$

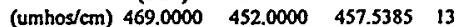

(F) $67.0000 \quad 62.0000 \quad 63.3684 \quad 19$

$\begin{array}{llll}\text { (NTU) } \quad 20.0000 & 20.0000 & 20.0000 & 3\end{array}$

$\begin{array}{lllll}(\mathrm{pCi} / \mathrm{L}) & 60.0000 & 50.0000 & 53.8000 \quad 5\end{array}$

$(\mathrm{mg} / \mathrm{L})<0.0010<0.0010<0.0010 \mathrm{~s}$

$(\mathrm{ug} / \mathrm{L})<250.0000<5.0000<130.83336$

$(\mathrm{ug} / \mathrm{L})<250.0000<5.0000<130.83336$

$(\mathrm{ug} / \mathrm{L})<250.0000<5.0000<130.83336$

$(\mathrm{ug} / \mathrm{L})<250.0000<5.0000<130.83336$

(ug/L) $<250.0000<5.0000<130.83336$

$(\mathrm{ug} / \mathrm{L})<250.0000<5.0000<130.83336$

(ug/L) $<250.0000<5.0000<130.83336$

(uR) $<250.0000<5.0000<130.83336$

$(\mathrm{ugL})<250.0000<5.0000<130.83336$

$(\mathrm{ug} / \mathrm{L})<250.0000<5.0000<130.83336$

$(\mathrm{ug} / \mathrm{L})<250.0000<5.0000<130.83336$

$(\mathrm{ug} / \mathrm{L})<250.0000<5.0000<130.83336$

$(\mathrm{ug} / \mathrm{L})<250.0000<5.0000<130.83336$

$(u g / L)<250.0000<5.0000<130.83336$

(ug/L) $<250.0000<5.0000<130.83336$

$\begin{array}{llll}\text { (ug/L) } \quad 1800.0000 & 8.0000 & 931.7727 \quad 22\end{array}$

(ug/L) $<500.0000<10.0000<261.66676$

$(u g / L)<500.0000<10.0000<261.66676$ 


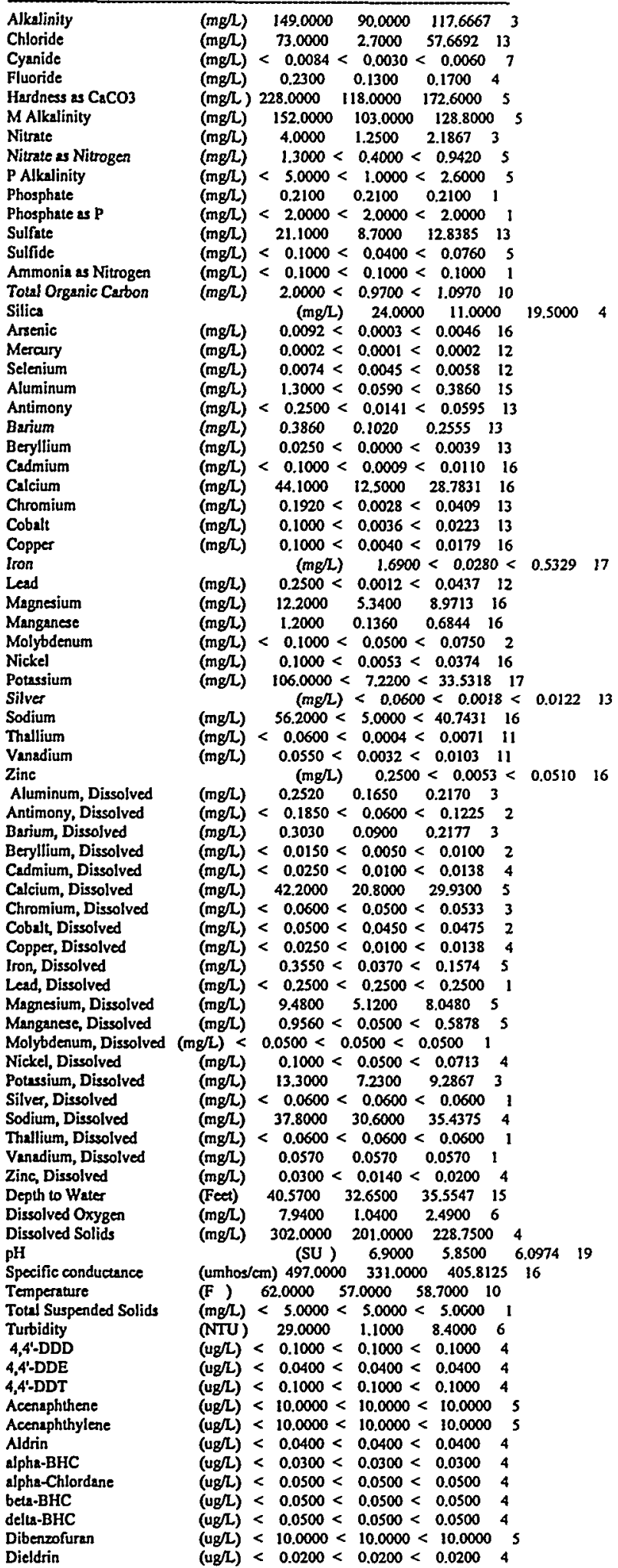




\begin{tabular}{|c|c|c|c|c|c|}
\hline Endosulfan I & $\mathrm{gg} / \mathrm{L})$ & $<0.0500$ & $<0.0500<$ & 0.0500 & \\
\hline Endosulfan II & $(\operatorname{ug} / L)$ & $<0.0400$ & $<0.0400<$ & 0.0400 & \\
\hline Endosulfan Sulfate & $(\operatorname{ug} / L)$ & $<0.1000$ & $<0.1000<$ & 0.1000 & 4 \\
\hline Endrin & (ug/L) & $<0.0600$ & $<0.0600<$ & 0.0600 & 4 \\
\hline Endrin Ketone & $(\mathrm{ug} / \mathrm{L})$ & $<0.1000$ & $<0.1000<$ & $<0.1000$ & 4 \\
\hline ImmE-BHC(Lindane) & $u g(L)<$ & $0.0400<$ & $0.0400<$ & 0.0400 & \\
\hline rima-Chlordane & $(u g / L)$ & $<0.0500$ & $<0.0500<$ & 0.0500 & 4 \\
\hline Heptachlor & $(\operatorname{ug} / \mathrm{L})$ & $<0.0300$ & $<0.0300<$ & 0.0300 & 4 \\
\hline Heptachlor Epoxide & $(\mathrm{ug} / \mathrm{L})$ & $<0.0500$ & $<0.0500<$ & $<0.0500$ & 4 \\
\hline Methoxychlor & $(\mathrm{ug} / \mathrm{L})$ & $<0.5000$ & $<0.5000<$ & $<0.5000$ & 4 \\
\hline PCB- & $($ ug $/ L)$ & $<0.5000$ & $<0.5000<$ & $<0.5000$ & 4 \\
\hline PCB-122! & $(\mathrm{ug} / \mathrm{L})$ & $<0.5000$ & $<0.5000<$ & 0.5000 & 4 \\
\hline PCB- & $(\operatorname{ug} / \mathrm{L})$ & $<0.5000$ & $<0.5000<$ & 0.5000 & 4 \\
\hline PCB-1242 & $(\mathrm{ug} / \mathrm{L})$ & $<0.5000$ & $<0.5000<$ & 0.5000 & 4 \\
\hline PCB-1248 & $(\mathrm{ug} / \mathrm{L})$ & $<0.5000$ & $<0.5000<$ & 0.5000 & 4 \\
\hline PCB-1254 & $(\mathrm{ug} / \mathrm{L})$ & $<0.5000$ & $<0.5000<$ & 0.5000 & 4 \\
\hline PCB-1260 & $(\operatorname{ug} / \mathrm{L})$ & $<0.5000$ & $<0.5000<$ & 0.5000 & 4 \\
\hline ene & $(\operatorname{ug} / \mathrm{L})$ & $<1.0000$ & $1.0000<$ & 1.0000 & 4 \\
\hline Gross Alpha & $(p \mathrm{Ci} / L)$ & 7.9000 & -13.3000 & 1.1625 & 8 \\
\hline Gross Beta & $(\mathrm{pCi} / \mathrm{L})$ & 158.0000 & 2.0000 & 47.8750 & 8 \\
\hline Neptunium-237 & $(\mathrm{pCi} / \mathrm{L})$ & 1.0000 & $0.4700<$ & $<0.82333$ & 3 \\
\hline um-239 & $(\mathrm{pCi} / \mathrm{L})$ & 1.6000 & $<-0.0220<$ & $<0.6945$ & 4 \\
\hline Rad Alpha & $(\mathrm{pCi} / \mathrm{mL}$ & 1.0000 & 1.0000 & 1.0000 & \\
\hline Rad Beta & (pCi/mL & L) $<1.0000$ & $<1.0000$ & $0<1.0000$ & 3 \\
\hline Radon 222 & $(\mathrm{pCi} / \mathrm{L})$ & 848.0000 & 848.0000 & 848.0000 & 1 \\
\hline ded Alpha & $(\mathrm{pCi} / \mathrm{L})$ & 1.4000 & 1.4000 & 1.4000 & 1 \\
\hline ded Beta & $(\mathrm{pCi} / 2)$ & 2.0000 & 2.0000 & 2.0000 & 1 \\
\hline $4 m-99$ & $(\mathrm{pC} \mathrm{i} / \mathrm{L})$ & 119.0000 & $<0.0000$ & $<16.0050$ & 20 \\
\hline$m-230$ & $(p \mathrm{Ci} / 2)$ & 0.6000 & $<-0.1100<$ & $<0.2593$ & 4 \\
\hline Uran & $(\mathrm{mg} / \mathrm{L})$ & $<0.0010$ & $<0.0010$ & $<0.0010$ & 5 \\
\hline$n-234$ & $(\mathrm{pCi} / \mathrm{L})$ & 0.6000 & $<0.0490<$ & $<0.3325$ & 4 \\
\hline 1.235 & $(\mathrm{pCi} / \mathrm{L})$ & 0.0170 & 0.0110 & 0.0140 & 2 \\
\hline n-238 & $(\mathrm{p} \mathrm{Ci} / \mathrm{L})$ & 0.6000 & $<-0.0016<$ & 0.3161 & 4 \\
\hline ed Alphs & $(\mathrm{pC} \mathrm{i} / \mathrm{L})$ & 0.0000 & -1.3000 & -1.3000 & 1 \\
\hline Disso & $(\rho \mathrm{Ci} / L)$ & 12.0000 & 12.0000 & 12.0000 & 1 \\
\hline izene & $(\mathrm{ug} / \mathrm{L})$ & $<10.0000$ & $=10.0000$ & $<10.0000$ & 5 \\
\hline 1,2 & $(u g / L)$ & $<10.0000$ & $<10.0000$ & $<10.0000$ & 7 \\
\hline & $(u g / L)$ & $<50.0000$ & $<50.0000$ & $<50.0000$ & 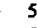 \\
\hline 2,4 & $(4 g / L)$ & $<10.0$ & $<10.0000$ & $<10.0000$ & 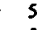 \\
\hline 4- & $(\mathrm{Ug} / \mathrm{L})$ & $<10.0000$ & $<10.0000$ & $<10.0000$ & 5 \\
\hline $2,4-1$ & $(\mathrm{ug} / \mathrm{L})$ & $<10.0000$ & $<10.0000$ & $<10.0000$ & 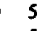 \\
\hline ol & $(\mathrm{ug} / \mathrm{L})$ & $<50.0000$ & $<50.0000$ & $<50.0000$ & 5 \\
\hline 2,4 & $(\mathrm{ug} / \mathrm{L})$ & $<10.0$ & $<10$. & $<10.0000$ & 3 \\
\hline $26-$ & $(\mathrm{ug} / \mathrm{L})$ & $<10.0000$ & $<10.0000$ & $<10.0000$ & 5 \\
\hline Ilene & (ug/L) & $<10.0000$ & $<10.0000$ & $<10.0000$ & 5 \\
\hline $2-0$ & (ug/L) & $<10.0000$ & $<10.0000$ & $<10.0000$ & 5 \\
\hline thalene & $(\mathrm{ug} / \mathrm{L})$ & $<10$. & $<10$. & $<10.0000$ & 5 \\
\hline اo & $(\mathrm{ug} / \mathrm{L})$ & $<10$. & $<10$. & $<10.0000$ & 5 \\
\hline $\mathrm{Ni}$ & $(\mathrm{ug} / \mathrm{L})$ & $<50.0000$ & $<50.0000$ & $<50.0000$ & 5 \\
\hline 2-Nit & $(u g / L)$ & $<10.0000$ & $<10.0000$ & $<10.0000$ & 5 \\
\hline benzidine & $(u g / L)$ & $<20.0$ & $<20.0000$ & $<20.0000$ & 5 \\
\hline $3-N$ & $(\operatorname{ug} / L)$ & $<50$. & $<$ so & $<50.0000$ & 5 \\
\hline $4,6-I$ & (ug/L) & $<50.0000$ & $<50.0000$ & $<50.0000$ & 5 \\
\hline -phenyleth & $g / L)<$ & $10.0000<$ & $10.0000<$ & $=10.0000$ & 5 \\
\hline 4-Chlc & $(g / L)<$ & $10.0000<$ & $10.0000<$ & 10.0000 & 5 \\
\hline 4-Ch & $(u g / L)$ & $<10.0000$ & $<10.0000$ & $<10.0000$ & 5 \\
\hline & $2 \pi)<$ & 10.00 & 10.00 & 10.000 & 5 \\
\hline $4-N$ & $(u g / L)$ & $<10.0000$ & $<10.0000$ & $<10.0000$ & 5 \\
\hline $4-1$ & $(\mathrm{ug} / \mathrm{L})$ & $<50$. & & $<50.0000$ & 5 \\
\hline $4-1$ & (ug/L) & 50.0 & $<15$. & $<43.0000$ & 5 \\
\hline & (ug/L) & $<10$. & $<10$ & $<<10.0000$ & 5 \\
\hline Ber & (ug/L) & $<10.0$ & $<10.0000$ & $0<10.0000$ & 5 \\
\hline Benzo(a)pyrene & $(\mathrm{ug} / \mathrm{L})$ & $<10.0$ & $<10.0000$ & $<10.0000$ & 5 \\
\hline Benzo(b)f & $(u g / L)$ & $<10$. & & $<10.0000$ & 5 \\
\hline & (ug/L) & $<10$. & $<10$ & $<10.0000$ & 5 \\
\hline Ber & $(u g / L)$ & $<10.0$ & $<10.0000$ & $<10.0000$ & 5 \\
\hline Benz & $(u g / L)$ & $<50.0$ & $<50.0000$ & $<<50.0000$ & 5 \\
\hline Ber & $(\operatorname{\omega g} / L)$ & $<10$. & $<10.0000$ & $0<10.0000$ & 5 \\
\hline & $(\mathrm{ug} / \mathrm{L})$ & $<10$. & $<10$. & $0<10.0000$ & 5 \\
\hline bi & $(\mathrm{ug} / \mathrm{L})$ & $<10.0$ & $<10.0000$ & $0<10.0000$ & 5 \\
\hline bis(2-Chloroethyl)ether & $(\mathrm{ug} / \mathrm{L})$ & $<10.0000$ & $<10.0000$ & $0<10.0000$ & 5 \\
\hline bis(2-Chloroisopropyl)e & $(\mathrm{ug} / \mathrm{L})$ & $<10.0000$ & $<10.0000$ & $0<10.0000$ & 5 \\
\hline & $(u g / L)$ & & $<10.0000$ & $<157.2000$ & \\
\hline & $(u g / L)$ & $<10.0$ & $<10.0000$ & $0<10.0000$ & 5 \\
\hline D & $(\mathrm{ug} / \mathrm{L})$ & J 10.0000 & $<2.0000$ & $<5.2000$ & 5 \\
\hline Di-n-octylphthalate & $(\mathrm{ug} / L)$ & $<10.0000$ & $<10.0000$ & $0<10.0000$ & 5 \\
\hline Dib & & $<10.0000$ & $<10.0000$ & $0<10.0000$ & 5 \\
\hline 1 & (ug/L) & 10.0000 & $<2.0000$ & $<8.4000$ & 5 \\
\hline Dimethylphthalate & $(u g / L)$ & $<10.0000$ & $<10.0000$ & $0<10.0000$ & 5 \\
\hline Fluoranthene & $(u g / L)$ & $<10.0000$ & $<10.0000$ & $0<10.0000$ & 5 \\
\hline Fluorene & $(u g / 2)$ & $<10.0000$ & $<10.0000$ & $0<10.0000$ & \\
\hline
\end{tabular}

Fluorene 


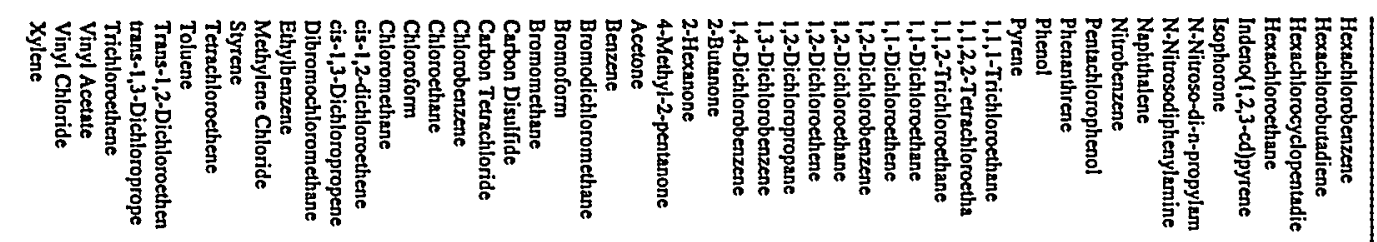

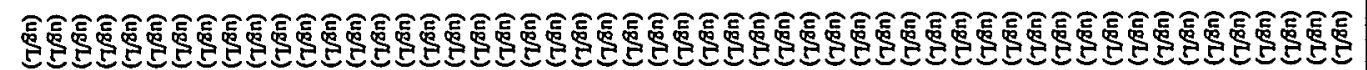

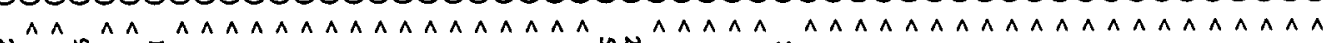

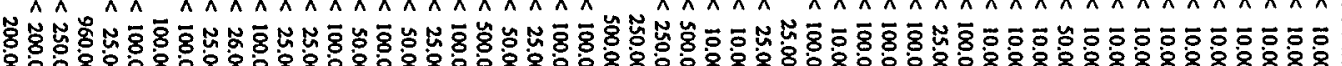

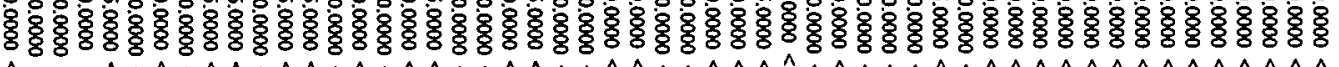

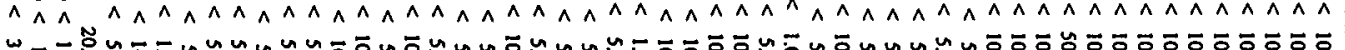

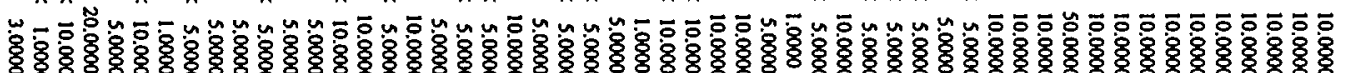

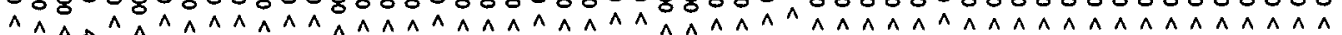

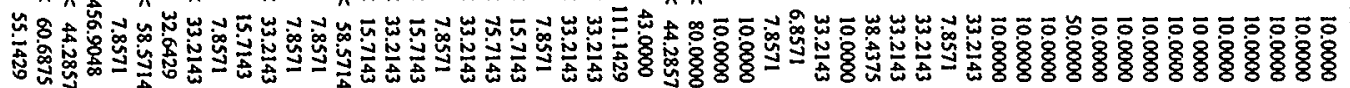

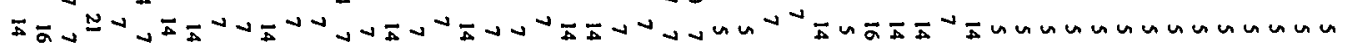


Environmental Information Management System

Data Summary for Sampling Station MW146 04/28/97

Analysis

(Units) Maximum Minimum Average Count

Alkalinity
Chloride
Cyanide
Fluoride
Nitrate as Nitsogen
Sulfate
Total Organic Carbon
Silica
Arsenic
Mercury
Selenium
Arsenic, Dissolved
Aluminum
Antimony
Barium
Beryllium
Cadmium
Calcium
Chromium
Cobalt
Copper
Iron
Lead
Magnesium
Manganese
Molybdenum
Nickel
Potassium
Silver
Sodium
Thallium
Vanadium
Zine
Aluminum, Dissolved
Antimony, Dissolved
Barium, Dissolved
Beryllium, Dissolved
Cadmium, Dissolved
Calcium, Dissolved
Chromium, Dissolved
Cobalt, Dissolved
Copper, Dissolved
Iron, Dissolved
Lead, Dissolved
Magnesium, Dissolved
Manganese, Dissolved
Molybdenum, Dissolved
Nickel, Dissolved
Potassium, Dissolved
Silver, Dissolved
Sodium, Dissolved
Thallium, Dissolved
Vanzdium, Dissolved
Depthethivity Water (Meter)
Dissolved Oxygen
Dissolved Solids
pH

$\begin{array}{lllll}(m g / L) & 87.0000 & 82.0000 & 85.1667 & 6\end{array}$

$\begin{array}{lllll}(\mathrm{mg} / \mathrm{L}) & 34.0000 & 25.0000 & 31.6800 & \mathrm{~s}\end{array}$

$(\mathrm{mg} / \mathrm{L})<0.0030<0.0030<0.0030$

$\begin{array}{lllll}0.1800 & 0.1600 & 0.1700 & 5\end{array}$

$\begin{array}{lllll}(\mathrm{mg} / \mathrm{L}) & 3.4000 & 2.9000 & 3.1200 & 5\end{array}$

$\begin{array}{lllll}(\mathrm{mg} / \mathrm{L}) & 9.0000 & 8.0000 & 8.7000 & 5\end{array}$

$1.0000<1.0000<1.000024$

$\begin{array}{lllll}(\mathrm{mg} / \mathrm{L}) & 21.0000 & 13.0000 & 16.3333 & 6\end{array}$

$(\mathrm{mg} / \mathrm{L}) \quad 0.0101<0.0050<0.00618$

$(\mathrm{mg} / \mathrm{L})<0.0002<0.0001<0.00026$

(mg/L) $0.0050<0.0009<0.00376$

$(\mathrm{mg} / \mathrm{L})<0.0050<0.0050<0.00501$

$(\mathrm{mg} / \mathrm{L}) \quad 7.1900<0.0195<2.24444$

$(\mathrm{mg} / \mathrm{L})<0.1850<0.0092<0.10439$

$\begin{array}{lllll}0.1600 & 0.0830 & 0.1131 \quad 8\end{array}$

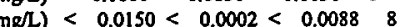

$(\mathrm{mg} / \mathrm{L})<0.0250<0.0006<0.01528$

$\begin{array}{lllll}(\mathrm{mg} / \mathrm{L}) & 24.4000 & 20.8000 & 22.9375 & 8\end{array}$

(mg/L) $0.0600<0.0013<0.04358$

$(\mathrm{mg} / \mathrm{L}) \mathrm{J}<0.0500<0.0026<0.03598$

$(\mathrm{mg} / \mathrm{L})<0.0250<0.0032<0.01588$

$(\mathrm{mg} / \mathrm{L})<0.2500<0.0006<0.16706$

$\begin{array}{lllll}(\mathrm{mg} / \mathrm{L}) & 8.5200 & 7.3300 & 7.8225 & 8\end{array}$

$(\mathrm{mg} / \mathrm{L}) \quad 0.3870<0.0200<0.11658$

$(\mathrm{mg} / \mathrm{L})<0.0500<0.0500<0.05002$

(mg/l) $<0.1000<0.0069<0.06349$

(mg/L) $\quad 10.5000<2.6800<6.93577$

$(\mathrm{mg} / \mathrm{L})<0.0600<0.0016<0.04056$

$\begin{array}{lllll}(\mathrm{mg} / \mathrm{L}) & 27.3000 & 24.2000 & 26.3250 & 8\end{array}$

$(\mathrm{mg} / \mathrm{L})<0.0600<0.0007<0.03635$

$(\mathrm{mg} / \mathrm{L}) \quad 0.0810<0.0010<0.04455$

(mg/L) $0.0380<0.0047<0.02049$

$\begin{array}{llll}0.2260 & 0.1330 & 0.1795 \quad 2\end{array}$

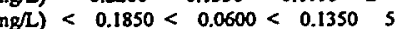

$\begin{array}{lllll}\mathrm{mg} / \mathrm{L}) & 0.0960 & 0.0820 & 0.0883 & 6\end{array}$

$(\mathrm{mg} / \mathrm{L})<0.0150<0.0050<0.01176$

$(\mathrm{mg} / \mathrm{L})<0.0250<0.0100<0.02006$

$\begin{array}{lllll}(\mathrm{mg} / \mathrm{L}) & 23.5000 & 20.2000 & 21.6333 & 6\end{array}$

mg/L) $<0.0600<0.0500<0.05676$

$(\mathrm{mg} / \mathrm{L})<0.0500<0.0450<0.04676$

$(\mathrm{mg} / \mathrm{L})<0.0250<0.0100<0.02006$

$(\mathrm{mg} / \mathrm{L}) \quad 0.3550<0.0100<0.25386$

$(\mathrm{mg} / \mathrm{L})<0.2500<0.2500<0.25004$

$\begin{array}{lllll}(\mathrm{mg} / \mathrm{L}) & 7.8400 & 7.1900 & 7.5383 \quad 6\end{array}$

(mg/L) $\quad 0.0200<0.0080<0.01636$

(mg/L) $<0.0500<0.0500<0.05002$

$(m g / L)<0.1000<0.0500<0.08336$

(mg/L) $10.5000<2.7100<7.4360$ s

$(\mathrm{mg} / \mathrm{L})<0.0600<0.0600<0.06004$

$\begin{array}{lllll}(\mathrm{mg} / \mathrm{L}) & 27.1000 & 21.6000 & 24.8167 & 6\end{array}$

$(\mathrm{mg} / \mathrm{L})<0.0600<0.0600<0.06002$

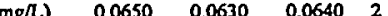

(me $<0.0300<0.0050<0.0222$

$\begin{array}{lllll}\text { (umhos/cm) } 318.0000 & 318.0000 & 318.0000\end{array}$

$\begin{array}{lllll}\text { Feet) } & 35.3900 & 25.0500 & 31.6238 & 16\end{array}$

$\begin{array}{lllll}(\mathrm{mg} / \mathrm{L}) & 5.7200 & 3.6700 & 4.8020 & \text { is }\end{array}$

$\begin{array}{lllll}(\mathrm{mg} / \mathrm{L}) & 187.0000 & 141.0000 & 170.8333 & 6\end{array}$

$\begin{array}{llllll}\text { SU ) } & 6.2000 & 5.7000 & 5.9904 & 52\end{array}$

pH

Temperature

Temperatu

Acenaphthene

Acenaphthylene

Dibenzofuran

Gross Alpha

Gross Bets

Neptunium-237

Plutonium-239

Red Alpha

Rad Bets

Redon 222

Technetium-99

Thorium-230

Uranium

Uranium-234

Uranium-235

Uranium-238

1,2,4-Trichlorobenzene

2,4,5-Trichlorophenol

2,4,6-Trichlorophenol

(umbos/cm) $3270000 \quad 300.0000319 .9400 \quad 50$

(F) $69.0000 \quad 56.0000 \quad 59.5438 \quad 16$

$\begin{array}{llll}\text { (NTU) } \quad 320.0000 & 0.8200 & 37.0400 & 13\end{array}$

(ug/L) $<10.0000<10.0000<10.0000$

$(\mathrm{ug} / \mathrm{L})<10.0000<10.0000<10.0000$,

$(\mathrm{ug} / \mathrm{L})<10.0000<10.0000<10.0000 \quad 1$

$\begin{array}{lllll}(\mathrm{pCi} / L) & 7.0000 & -2.9000 & 2.0235 & 17\end{array}$

$\begin{array}{lllll}\text { (pCi/L) } \quad 32.0000 & -6.0000 & 7.0000 & 17\end{array}$

$5.0000<1.1000<3.050017$

(pCiL) $5.0000<1.1000<3.051$

(pCi/L) $0.1000<0.0016<0.04293$

$(\mathrm{pCi} / \mathrm{ml})<1.0000<1.0000<1.0000$

$(\mathrm{pCi} / \mathrm{ml})<1.0000<1.0000<1.0000 \quad$ ।

$\begin{array}{lllll}\text { (pCiL) } \quad 468.0000 & 214.0000 & 375.0000 \quad 4\end{array}$

(pCi/L) $\quad 15.0000<-0.5000<4.823921$

(pCi/L) $\quad 1.3000<-0.2800<0.35673$

(pCI/) $<0.0010<0.0010<0.00107$

(pCi/L) $0.0640<0.0280<0.04403$

(PCi/L) $0.0300<0.0270<0.02833$

(pCi/L) $0.1600<-0.0280<0.05403$

(ug/L) $<10.0000<10.0000<10.0000$

$(u g / L)<50.0000<50.0000<50.0000$

$(u g / L)<10.0000<10.0000<10.00001$ 


\begin{tabular}{|c|c|c|c|c|c|c|}
\hline & L) & $\mathrm{s}^{2}$ & 10.0000 & 10.0000 & & \\
\hline enol & $e j$ & $<$ & 10.0000 & 10.0000 & 10.0000 & \\
\hline & (L) & $<$ & 50.0000 & 50.0000 & 50.0000 & \\
\hline initrotol & $g / L)$ & $<$ & $10.0000<$ & $<10.0000<$ & & \\
\hline 6-Dinitrotoluene & 2/L) & $<$ & & $10.0000<$ & & \\
\hline thalene & $(g / L)$ & $<$ & 10.0000 & 10.0000 & 10.0000 & \\
\hline & $B(L)$ & $<$ & 10.0000 & 10.0000 & 10.0000 & \\
\hline & $g(L)$ & $<$ & 10.0000 & 10.0000 & 10.0000 & \\
\hline & (f) & $<$ & & $<10.0000<$ & 10.0000 & \\
\hline Nitro & (ug/L) & $<$ & & & & \\
\hline ol & (ug/L) & $<$ & & 10.0000 & 000 & \\
\hline ine & $g / L)$ & $<$ & 20.0000 & 20.0000 & 000 & \\
\hline & $g / L)$ & $<$ & 50.0000 & 50.0000 & 000 & 1 \\
\hline $4,6-1$ & $(u g / L)$ & $<$ & $50.0000<$ & $50.0000<$ & 50.0000 & 1 \\
\hline 4-Bno & $\mathrm{g} / \mathrm{L})<$ & & $0.0000<1$ & $10.0000<1$ & 10.0 & \\
\hline or & $(u g / L)$ & $<$ & $10.0000<$ & $10.0000<$ & $<10$ & I \\
\hline & (ug/L) & $<$ & & $<10.0000<$ & $<10$ & \\
\hline & $(u g / L)$ & $<$ & & $<10.0000<$ & $<10$ & I \\
\hline $4-M$ & $(u g / L)$ & $<$ & & $300<$ & $<1$ & 1 \\
\hline 4-Nitro & (ug/L) & $<$ & $100<$ & $<50.0000<$ & $<50$ & \\
\hline tous & $(u g / L)$ & $<$ & $\infty<<$ & 50.0000 & 000 & \\
\hline & $(u g / L)$ & $<$ & & & 300 & \\
\hline & $g / L)$ & $<$ & & $000<$ & $<10$ & I \\
\hline Ben & $g / L)$ & $<$ & $00<$ & $000<$ & $<10$ & 1 \\
\hline Ben & $(u g / L)$ & $<$ & $0<<$ & $000<$ & $<10$ & $\mathbf{1}$ \\
\hline Benzol & $(u g / L)$ & $<$ & $00<$ & $000<$ & $<10$. & 1 \\
\hline ne & $(\operatorname{ug} / \mathrm{L})$ & $<$ & & & 000 & 1 \\
\hline & $(\mu g / L)$ & $<$ & & & 000 & 1 \\
\hline & $(u g / L)$ & $<$ & & & & I \\
\hline Ben & $(u g / L)$ & $<$ & $0<$ & $100<$ & $<10$ & $\mathbf{1}$ \\
\hline ieth & $(u g / L)$ & $<$ & $0<$ & $100<$ & $<10$ & 1 \\
\hline $\operatorname{bis}(2$ & $(U g / \mathcal{L})$ & $<$ & & $<10$ & 300 & 1 \\
\hline & $g / L)$ & $<$ & & & $<10$ & I \\
\hline & $(\operatorname{ug} / L)$ & $<$ & & & & $\mathbf{I}$ \\
\hline $\mathrm{Ch}_{\mathrm{h}}$ & $(\cup g / L)$ & $<$ & $0<$ & $00<$ & $<10$ & 1 \\
\hline ate & $(u g / L)$ & $<$ & $0<$ & $100<$ & $<10$ & 1 \\
\hline & $(u g / L)$ & $<$ & & & & 1 \\
\hline & (ug/L) & $<$ & & & & 1 \\
\hline & (ug/L) & $<$ & $0<$ & $00<$ & $<10$ & 1 \\
\hline halate & $(u g / L)$ & $<$ & $0<$ & $100<$ & $<10$ & 1 \\
\hline & $g / L)$ & $<$ & & & & 1 \\
\hline & (Ug/L) & $<$ & & & & 1 \\
\hline & g/L) & $<$ & $0<$ & $00<$ & $<10$ & 1 \\
\hline $\mathrm{He}$ & (ug/L) & $<$ & 10. & $100<$ & $<10$ & 1 \\
\hline & (ug/L) & $<$ & & & & 1 \\
\hline & (ug/L) & $<$ & & & & 1 \\
\hline & $(u g / L)$ & $<$ & & & $<10$ & 1 \\
\hline & (ug/L) & $<$ & $0<$ & $100<$ & $<10$ & 1 \\
\hline & (ug/L) & $<$ & & & & 1 \\
\hline re & (ug/L) & $<$ & & & & 1 \\
\hline & (ug/L) & $<$ & $0<$ & $<10$ & $<10$. & 1 \\
\hline & (ug/L) & $<$ & 10.0 & $<10.0000<$ & $<10.0000$ & 1 \\
\hline $\mathrm{Pe}$ & (ug/L) & $<$ & so & so & 50. & 1 \\
\hline & (ug/L) & $<$ & & & & 1 \\
\hline & (L) & $<$ & 10 & & $<10$ & l \\
\hline & (ugll) & $<$ & 10. & $100<$ & 10.0000 & 1 \\
\hline & $g / L$ & $<$ & $0<$ & 5. & 5.0000 & 11 \\
\hline 1, & b) & $<$ & 5. & & & 2 \\
\hline & (ug/L) & $<$ & $0<$ & & 001 & 11 \\
\hline & $(\operatorname{ug} / L)$ & $<$ & $30<$ & $00<$ & 5.0000 & 11 \\
\hline & $g / L)$ & $<$ & $0<$ & $00<$ & 5.0000 & 11 \\
\hline & $g / L)$ & $<$ & & & & 1 \\
\hline & $y(L)$ & $<$ & & $0<<$ & 5.0000 & 11 \\
\hline & (ug/L) & $<$ & $0<$ & $5.0000<$ & 5.0000 & 2 \\
\hline & $1 \mathrm{~g} / \mathrm{L})$ & $<$ & $0<<$ & $5.0000<$ & 5.0000 & 2 \\
\hline & $(u g / L)$ & $<$ & 10. & $<10$. & $<10.0000$ & 1 \\
\hline obenzene & & $<$ & & & $<10.0000$ & 1 \\
\hline & & $<$ & & $00<$ & 10.0000 & 2 \\
\hline & ug(L) & $<$ & $00<$ & $000<$ & $<10.0000$ & 2 \\
\hline 4-Met & & $<$ & & 10.0000 & $<10.0000$ & 2 \\
\hline & & $<$ & & $0<<$ & & 2 \\
\hline & & $<$ & $0<$ & $5.0000<$ & $=5.0000$ & 11 \\
\hline or & $g / L)$ & $<$ & 5.0 & 5.0000 & 5.0000 & 11 \\
\hline Bromoform & $(u g / L)$ & $<$ & $5.0000<$ & $<5.0000<$ & 5.0000 & 2 \\
\hline Bromometha & & $<$ & $10.0000<$ & $<10.0000<$ & $<10.0000$ & \\
\hline 1 & & $<$ & 5.0000 & 5.0000 & 5.0000 & 2 \\
\hline$c$ & & & 5.0000 & $5.0000<$ & $=5.0000$ & 11 \\
\hline Chlorobenzene & (ug/L) & $<$ & $5.0000<$ & $<5.0000<$ & 5.0000 & 2 \\
\hline Whom & & & $10.0000<$ & $<10.0000<$ & $<10.0000$ & \\
\hline & L) & & & 5.00 & 5.0000 & II \\
\hline & & & 10.00 & w & 10.0000 & \\
\hline
\end{tabular}

Data Summary for Sampling Station MW146 04/28/97

Environmental Information Management System

Analysis

(Units) Maximum Minimum Average Count

cis-1,2-dichloroethene

$(\mathrm{ug} / \mathrm{L})<5.0000<5.0000<5.00009$ 


$\begin{array}{ll}\text { cis-1,3-Dichloropropene } & (\mathrm{ug} / \mathrm{L})<5.0000<5.0000<5.0000 \quad 2 \\ \text { Dibromochloromethane } & (\mathrm{ug} / \mathrm{L})<5.0000<5.0000<5.00002 \\ \text { Ethylbenzene } & (\mathrm{ug} / \mathrm{L})<5.0000<5.0000<5.000011 \\ \text { Methylene Chloride } & (\mathrm{ug} / \mathrm{L})<16.0000<8.0000<12.00002 \\ \text { Styrene } & (\mathrm{ug} / \mathrm{L})<5.0000<5.0000<5.00002 \\ \text { Tetrachloroethene } & (\mathrm{ug} / \mathrm{L})<5.0000<5.0000<5.000011 \\ \text { Toluene } & (\mathrm{ug} / \mathrm{L})<5.0000<5.0000<5.000011 \\ \text { Trans-1,2-Dichloroethene } & (\mathrm{ug} / \mathrm{L})<5.0000<5.0000<5.000019 \\ \text { trans-1,3-Dichloroprope } & (\mathrm{ug} / \mathrm{L})<5.0000<5.0000<5.00002 \\ \text { Trichloroethene } & (\mathrm{ug} / \mathrm{L})<3.3000<1.0000<1.865020 \\ \text { Vinyl Acetate } & (\mathrm{ug} / \mathrm{L})<10.0000<10.0000<10.00002 \\ \text { Vinyl Chloride } & (\mathrm{ug} / \mathrm{L})<10.0000<1.0000<8.727311 \\ \text { Xylene } & (\mathrm{ug} / \mathrm{L})<10.0000<5.0000<8.636411\end{array}$




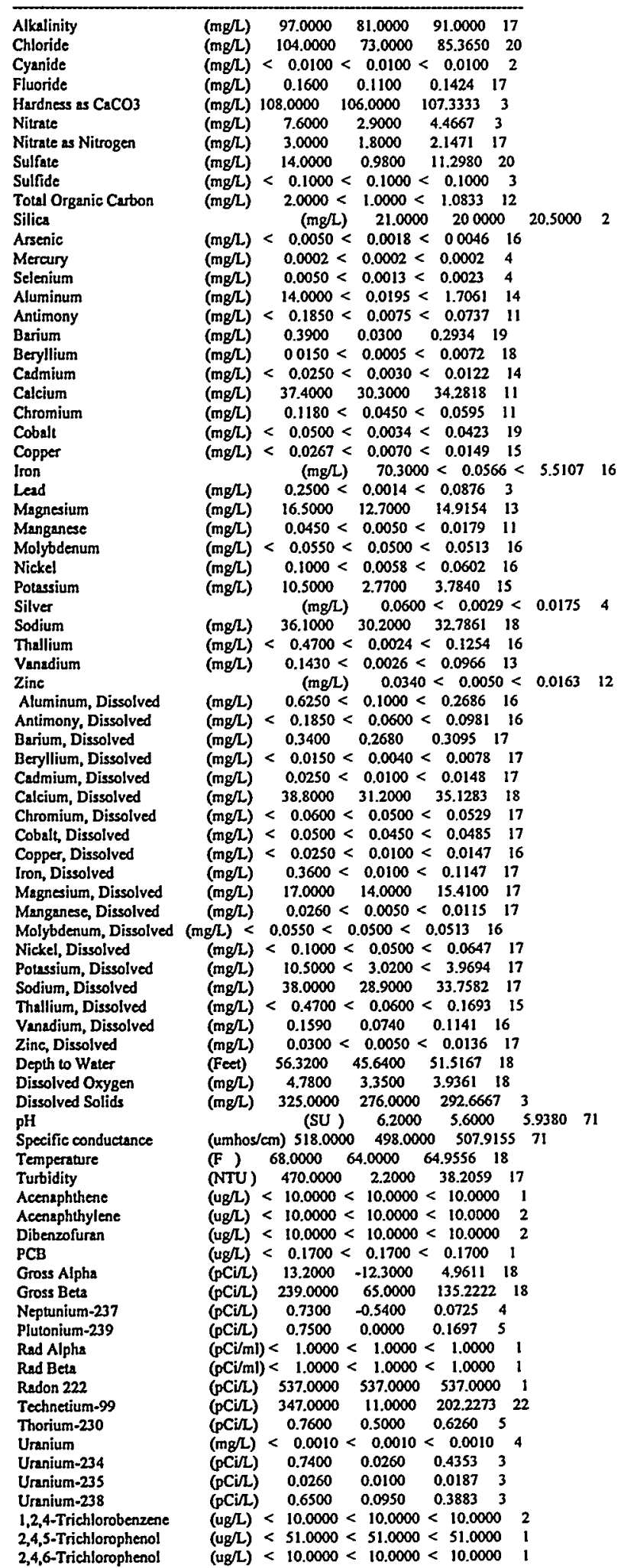




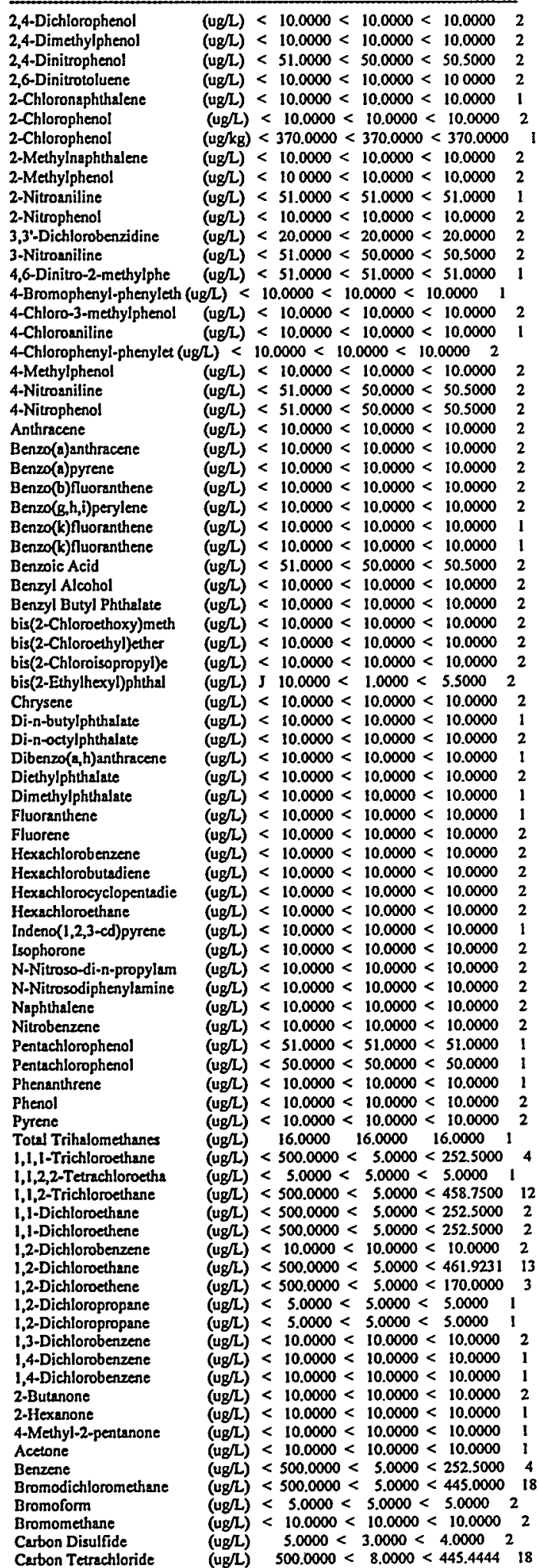

Environmental Information Management System

Data Summary for Sampling Station MW155 04/28/97 


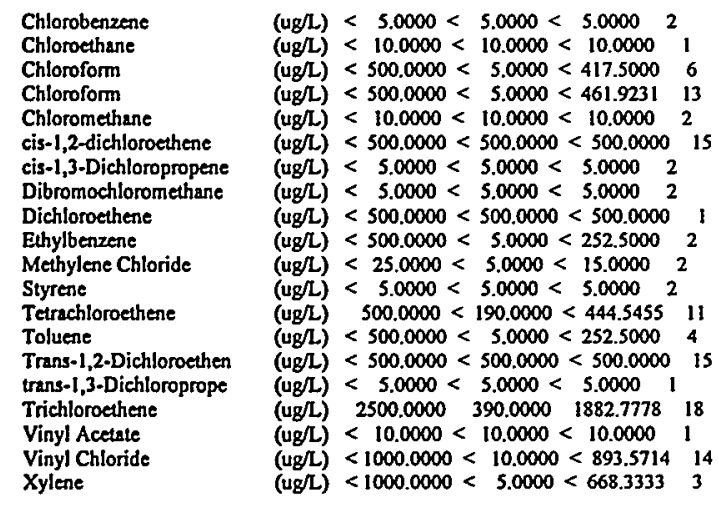


Environmental Information Management System

Data Summary for Sampling Station MW157 04/28/97

\begin{tabular}{|c|c|c|c|c|c|c|}
\hline \multirow{2}{*}{$\frac{\text { Analysis }}{\text { Alkalinity }}$} & \multicolumn{2}{|r|}{ (Units) } & Maximum & Minimum & \multirow{2}{*}{ Average } & e Count \\
\hline & $(\mathrm{mg} / \mathrm{L})$ & 215.0000 & 43.0000 & $69.1667 \quad 12$ & & \\
\hline Chloride & $(\mathrm{mg} / \mathrm{L})$ & 155.9000 & 19.0000 & $39.3462 \quad 13$ & & \\
\hline Cyanide & $(m g / L)$ & $<0.0030<$ & $=0.0000$ & $<0.00152$ & & \\
\hline Fluoride & $(m g / L)$ & $0.1700<$ & $0.1000<$ & $<0.1058 \quad 12$ & & \\
\hline Hardness as $\mathrm{CaCO}$ & $(m g / L)$ & $62.0000 \quad 62$ & 2.00006 & $62.0000 \quad 1$ & & \\
\hline Nitrale as Nitrogen & $(\mathrm{mg} / \mathrm{L})$ & $1.9000<$ & $0.4700<$ & $<1.1669 \quad 13$ & & \\
\hline Phosphate & $(\mathrm{mg} / \mathrm{L})$ & 0.1100 & 0.1100 & $0.1100 \quad 1$ & & \\
\hline Sulfate & $(m g / L)$ & 136.0000 & 8.7000 & $112.3615 \quad 13$ & & \\
\hline Sulfide & $(m g / L)$ & $<0.4000<$ & $=0.4000$ & $<0.40001$ & & \\
\hline Ammonia as Nitrogen & $(\mathrm{mg} / \mathrm{L})$ & $<0.1000<$ & $=0.1000$ & $<0.10001$ & & \\
\hline Total Organic Carton & $(\mathrm{mg} / \mathrm{L})$ & 3.0000 & 2.0000 & $2.3846 \quad 13$ & & \\
\hline Silica & & $(\mathrm{mg} / \mathrm{L})$ & 30.000 & $00 \quad 17.0000$ & 23.5000 & 2 \\
\hline Arsenic & $(\mathrm{mg} / \mathrm{L})$ & $0.0148<$ & $0.0018<$ & $<0.0057 \quad 16$ & & \\
\hline Mercury & $(\mathrm{mg} / \mathrm{L})$ & $<0.0002<$ & $=0.0001$ & $<0.00025$ & & \\
\hline Selenium & $(m g / L)$ & $<0.0050<$ & $=0.0008$ & $<0.0020 \mathrm{~s}$ & & \\
\hline Arsenic, Dissolved & $(\mathrm{mg} / \mathrm{L})$ & 0.0070 & 0.0070 & $0.0070 \quad 1$ & & \\
\hline Aluminum & $(\mathrm{mg} / \mathrm{L})$ & $65.6000<$ & 0.0161 & $<4.8507 \quad 16$ & & \\
\hline Antimony & $(\mathrm{mg} / \mathrm{L})$ & $0.1850<$ & $0.0075<$ & $<0.0556 \quad 17$ & & \\
\hline Barium & $(\mathrm{mg} / \mathrm{L})$ & 0.4260 & 0.0450 & $0.0913 \quad 17$ & & \\
\hline Beryllium & $(m g / L)$ & $0.0150<$ & $0.0002<$ & $<0.0046 \quad 17$ & & \\
\hline Cadmium & $(\mathrm{mg} / \mathrm{L})$ & $<0.0250<$ & $<0.0011$ & $<0.0091 \quad 17$ & & \\
\hline Calcium & $(\mathrm{mg} / \mathrm{L})$ & 39.0000 & 14.9000 & $21.0559 \quad 17$ & & \\
\hline Chromium & $(\mathrm{mg} / \mathrm{L})$ & $0.1890<$ & $0.0016<$ & $<0.0510 \quad 17$ & & \\
\hline Cobalt & $(m g / L)$ & $0.0500<$ & $0.0024<$ & $<\quad 0.0402 \quad 17$ & & \\
\hline Copper & $(m g / L)$ & $0.0254<$ & $0.0014<$ & $<0.0104 \quad 17$ & & \\
\hline Iron & & (mg/L) & 89.700 & $00<0.0121<$ & $<6.3914$ & 16 \\
\hline Lead & $(\mathrm{mg} / \mathrm{L})$ & $0.2500<$ & $0.0005<$ & $<0.05735$ & & \\
\hline Magnesium & $(\mathrm{mg} / \mathrm{L})$ & 14.4000 & 5.6300 & $7.6319 \quad 16$ & & \\
\hline Manganese & $(m g / L)$ & $0.5110<$ & $0.0003<$ & $<0.063416$ & & \\
\hline Molybidenum & $(m g / L)$ & $<0.0500<$ & $<0.0500$ & $<0.0500 \quad 11$ & & \\
\hline Nickel & & $(m g / L)$ & 0.4150 & $50<0.0036<$ & 0.0644 & 16 \\
\hline Potassium & $(m g / L)$ & $3.6400<$ & $0.5260<$ & $<1.9541 \quad 15$ & & \\
\hline Silicon & $(m g / L)$ & 97.4000 & 97.4000 & $97.4000 \quad 1$ & & \\
\hline Silver & & $(m g / L)$ & $<0.060$ & $00<0.0018$ & $<0.0139$ & 95 \\
\hline Sodium & $(\mathrm{mg} / \mathrm{L})$ & 119,0000 & 32.5000 & $64.9850 \quad 16$ & & \\
\hline Thallium & $(m g /)$ & $0.0600<$ & $0.0007<$ & $<0.045316$ & & \\
\hline Vanadium & $(m g / L)$ & $0.1780<$ & $0.0011<$ & $<0.0578 \quad 16$ & & \\
\hline Zinc & & (mg/L) & 0.1030 & $30<0.0030<$ & $=0.0170$ & 17 \\
\hline Aluminum, Dissolved & $(\mathrm{mg} / \mathrm{L})$ & $0.2820<$ & $0.1000<$ & $<0.1466 \quad 11$ & & \\
\hline Antimony, Dissolved & $(m g /)$ & $<0.1850<$ & $<0.0600$ & $<0.0704 \quad 12$ & & \\
\hline Barium, Dissolved & $(m g / L)$ & 0.2100 & 0.0450 & $0.0683 \quad 12$ & & \\
\hline Beryllium, Dissolved & $(m g / L)$ & $<0.0150<$ & $<0.0040$ & $<0.0058 \quad 12$ & & \\
\hline Cadmium, Dissolved & $(\mathrm{mg} / \mathrm{L})$ & $<0.0250<$ & $<0.0100$ & $<0.0113 \quad 12$ & & \\
\hline Calcium, Dissolved & $(\mathrm{mg} / \mathrm{L})$ & 32.7000 & 15.9000 & $19.5417 \quad 12$ & & \\
\hline Chromium, Dissolved & $(m g / L)$ & $<0.0600<$ & $<0.0500$ & $<0.0508 \quad 12$ & & \\
\hline Cobalt, Dissolved & $(m g / L)$ & $<0.0500<$ & $<0.0450$ & $<0.0495 \quad 11$ & & \\
\hline Copper, Dissolved & $(m g / L)$ & $<0.0500<$ & $<0.0100$ & $<\quad 0.0146 \quad 12$ & & \\
\hline Iron, Dissolved & $(m g h)$ & $0.3550<$ & 0.0100 & $<0.0514 \quad 11$ & & \\
\hline Lead, Dissolved & $(m g / h)$ & $<0.2500<$ & $<0.2500$ & $<0.2500 \quad 1$ & & \\
\hline Magnesium, Dissolved & $(m g /)$ & 15.0000 & 6.1600 & $\begin{array}{ll}7.7900 & 12\end{array}$ & & \\
\hline Manganese, Dissolved & $(m g / L)$ & $0.0620<$ & 0.0050 & $<0.0211 \quad 12$ & & \\
\hline Molybdenum, Dissolved & $(m g / L)<$ & $0.0500<0$ & $0.0500<$ & $0.0500 \quad 10$ & & \\
\hline Nickel, Dissolved & $(\mathrm{mg} / \mathrm{L})$ & $0.3790<$ & 0.0500 & $<0.0799 \quad 11$ & & \\
\hline Potrssium, Dissolved & $(m g / L)$ & $<2.0000<$ & $<2.0000$ & $<2.0000$ & & \\
\hline Silver, Dissolved & $(m g / L)$ & $<0.0600<$ & $<0.0600$ & $<0.0600 \quad 1$ & & \\
\hline Sodium, Dissolved & $(m g / L)$ & 123.0000 & 54.4000 & $70.6455 \quad 1$ & & \\
\hline Thellium, Dissolved & $(m g / L)$ & $0.1090<$ & 0.0600 & $<0.0645 \quad 11$ & & \\
\hline Vanadium, Dissolved & $(m g / L)$ & $0.0840<$ & 0.0500 & $<0.0595 \quad 10$ & & \\
\hline Zinc, Dissolved & $(m g / L)$ & $0.0300<$ & $=0.0050$ & $<0.0100 \quad 11$ & & \\
\hline Depth to Water & (Fet) & 35.2000 & 0.0000 & $29.9367 \quad 15$ & & \\
\hline Dissolved Oxygen & $(\mathrm{mg} / \mathrm{L})$ & 10.4200 & 6.7200 & $\begin{array}{ll}8.8500 & 13\end{array}$ & & \\
\hline Dissolved Solids & $(m g / L)$ & 542.0000 & 307,0000 & $0 \quad 382.2500$ & 4 & \\
\hline pH & & (SU) & 7.3000 & 0.0000 & 5.9857 & 35 \\
\hline Specific conductance & (umhos/ & $/(\mathrm{cm}) 905.0000$ & $0 \quad 442.00$ & $000 \quad 527.0750$ & 40 & \\
\hline Temperature & (F) & 75.9000 & 50.0000 & $\begin{array}{lll}64.3846 & 13\end{array}$ & & \\
\hline Total Suspended Solids & $(m g / L)$ & 206.0000 & 206.0000 & $0 \quad 206.0000$ & 1 & \\
\hline Turbidity & (NTU) & 125.0000 & 0.6100 & $31.3677 \quad 13$ & 13 & \\
\hline Acenaphthene & $(\mathrm{ug} / \mathrm{L})$ & $<11.0000<$ & $<10.0000$ & $0<10.5000$ & 2 & \\
\hline Acenaphthylene & $(\mathrm{ug} / \mathrm{L})$ & $<11.0000<$ & $<10.0000$ & $0<10.5000$ & 2 & \\
\hline Dibenzofuran & (ug/L) & $<11.0000<$ & $<10.0000$ & $0<10.5000$ & 2 & \\
\hline PCB & $(u g / L)$ & $<0.1700<$ & $<0.1700$ & $<0.1700 \quad 1$ & & \\
\hline PCB-1016 & $(u g / L)$ & $<0.5000<$ & $<0.5000$ & $<0.5000 \quad 1$ & & \\
\hline PCB-1221 & $(u g / L)$ & $<1.2000<$ & $<1.2000$ & $<1.20001$ & & \\
\hline PCB-1232 & (ug/L) & $<1.2000<$ & $<1.2000$ & $<1.2000 \quad 1$ & & \\
\hline PCB -1242 & $(u g / L)$ & $<0.5000<$ & $<0.5000$ & $<0.5000 \quad 1$ & & \\
\hline PCB-1248 & $(u g / L)$ & $<0.2000<$ & $<0.2000$ & $<0.2000 \quad 1$ & & \\
\hline PCB-1254 & (ug/L) & $<0.2000<$ & $<0.2000$ & $<0.2000 \quad 1$ & & \\
\hline PCB- 1260 & $(u g / L)$ & $<0.2000<$ & $<0.2000$ & $<0.2000 \quad 1$ & & \\
\hline Gross Alpha & $(\mathrm{pC} \mathrm{i} / \mathrm{L})$ & 5.7000 & -4.0000 & $1.9000 \quad 12$ & & \\
\hline Gross Bets & $(\rho C i / L)$ & 89.0000 & 1.0000 & $36.9167 \quad 12$ & & \\
\hline Neptunium-237 & $(\mathrm{pCi} / \mathrm{L})$ & 0.9000 & -0.3600 & $0.3000 \quad 4$ & & \\
\hline
\end{tabular}




\begin{tabular}{|c|c|c|c|c|c|}
\hline Plutonium-239 & $(\mathrm{pCi} / \mathrm{L})$ & 0.1000 & 0.0000 & 0.0396 & \\
\hline Rad Alphe & $(\mathrm{pCi} / \mathrm{ml})$ & )$<1.0000$ & 1.0000 & $<1.0000$ & 1 \\
\hline Rad Beta & $(\mathrm{pCi} / \mathrm{ml})$ & )$<1.0000$ & 1.0000 & $<1.0000$ & 1 \\
\hline Radon 222 & $(\mathrm{pCi} / \mathrm{L})$ & 461.0000 & 461.0000 & 461.0000 & 1 \\
\hline Technetium-99 & $(\mathrm{pCi} / \mathrm{L})$ & 106.0000 & $<0.0000$ & $<57.88241$ & 17 \\
\hline Thorium-230 & $(\mathrm{pCi} / \mathrm{L})$ & 0.7000 & 0.0570 & 0.3074 & \\
\hline Uranium & $(\mathrm{mg} / \mathrm{L})$ & $<0.0010$ & $<0.0010<$ & $<0.0010$ & 3 \\
\hline Uranium-234 & $(\mathrm{pCi} / \mathrm{L})$ & 0.3600 & -0.0038 & $0.1554 \quad 3$ & \\
\hline Uranium-235 & $(p C i / L)$ & 0.0330 & 0.0100 & $0.0233 \quad 3$ & \\
\hline Uranium-238 & $(p C i / L)$ & 0.7000 & 0.0270 & $0.4357 \quad 3$ & \\
\hline 1,2,4-Trichlorobenzene & $(u g / L)$ & $<11.0000$ & $<10.0000$ & $<10.5000$ & 2 \\
\hline ichlorophenol & $(\lg / L)$ & $<53.0000$ & $<50.0000$ & $<51.5000$ & 2 \\
\hline 2,4,6-Trichlorophenol & $(u g / L)$ & $<11.0000$ & $<10.0000$ & $<10.5000$ & 2 \\
\hline 2,4-Dichlorophenol & $(u g / L)$ & $<11.0000$ & $<10.0000$ & $<10.5000$ & 2 \\
\hline 2,4-Dimethylphenol & $(\operatorname{ug} / L)$ & $<11.0000$ & $<10.0000$ & $<10.5000$ & 2 \\
\hline 2,4-Dinitrophenol & $(\operatorname{ug} / \mathrm{L})$ & $<53.0000$ & $<50.0000$ & $<51.5000$ & 2 \\
\hline 2,4-Dinitrotoluene & $(U g / L)$ & $<11.0000$ & $<10.0000$ & $<10.5000$ & 2 \\
\hline 2,6-Dinitrotoluene & $(u g / L)$ & $<11.0000$ & $<10.0000$ & $<10.5000$ & 2 \\
\hline 2-Chloronaphthalene & (ug/L) & $<11.0000$ & $<10.0000$ & $<10.5000$ & 2 \\
\hline 2-Chlorophenol & $(u g / L)$ & $<11.0000$ & $<10.0000$ & $<10.5000$ & 2 \\
\hline 2-Methylnaphthalene & (ug/L) & $<11.0000$ & $<10.0000$ & $<10.5000$ & 2 \\
\hline 2-Methylphenol & (ug/L) & $<11.0000$ & $<10.0000$ & $<10.5000$ & 2 \\
\hline 2-Nitroaniline & (ug/L) & $<53.0000$ & $<50.0000$ & $<51.5000$ & 2 \\
\hline 2-Nitrophenol & $(u g / L)$ & $<11.0000$ & $<10.0000$ & $<105000$ & 2 \\
\hline 3,3'-Dichlorobenzidine & $(u g / L)$ & $<21.0000$ & $<20.0000$ & $<20.5000$ & 2 \\
\hline 3-Nitroaniline & (ug/L) & $<53.0000$ & $<50.0000$ & $<51.5000$ & 2 \\
\hline 4,6-Dinitro-2-methylphe & $(u g / L)$ & $<53.0000$ & $<50.0000$ & $<51.5000$ & 2 \\
\hline 4-Bromophenyl-phenyleth & $1 g(L)<$ & $11.0000<$ & $10.0000<$ & 10.5000 & \\
\hline 4-Chloro-3-methylphenol ( & & $11.0000<$ & $10.0000<$ & 10.5000 & \\
\hline 4-Chloroaniline & $(\mathrm{Ug} / \mathrm{L})$ & $<11.0000$ & $<10.0000$ & $<10.5000$ & 2 \\
\hline 4-Chlorophenyl-phenylet & $y / L)<$ & $11.0000<$ & $10.0000<1$ & 10.5000 & \\
\hline 4-Methylphenol & (ug/L) & $<11.0000$ & $<10.0000$ & $<10.5000$ & 2 \\
\hline 4-Nitroaniline & (ug/L) & $<53.0000$ & $<50.0000$ & $<51.5000$ & 2 \\
\hline 4-Nitrophenol & (Ug/L) & $<53.0000$ & $<50.0000$ & $<51.5000$ & 2 \\
\hline Anthracene & (ug/L) & $<11.0000$ & $<10.0000$ & $<10.5000$ & 2 \\
\hline Benzo(s)anthracene & (ug/L) & $<11.0000$ & $<10.0000$ & $<10.5000$ & 2 \\
\hline Benzo(a)pytene & (ug/L) & $<11.0000$ & $<10.0000$ & $<10.5000$ & 2 \\
\hline Benzo(b)fluoranthene & $(u g / L)$ & $<11.0000$ & $<10.0000$ & $<10.5000$ & 2 \\
\hline Benzo(g,h,i)perylene & $(u g / L)$ & $<11.0000$ & $<10.0000$ & $<10.5000$ & 2 \\
\hline Benzo(k)fluoranthene & $(u g / L)$ & $<11.0000$ & $<10.0000$ & $<10.5000$ & 2 \\
\hline Benzoic Acid & $(\mathrm{ug} / \mathrm{L})$ & $<53.0000$ & $<50.0000$ & $<\$ 1.5000$ & 2 \\
\hline Benzyl Alcohol & $(u g / L)$ & $<11.0000$ & $<10.0000$ & $<10.5000$ & 2 \\
\hline Benzyl Butyl Phthalate & $(u g / L)$ & $<11.0000$ & $<10.0000$ & $<10.5000$ & 2 \\
\hline bis(2-Chloroethoxy)meth & (ug/L) & $<11.0000$ & $<10.0000$ & $<10.5000$ & 2 \\
\hline bis(2-Chloroethyl)ether & $(u g / L)$ & $<11.0000$ & $<10.0000$ & $<10.5000$ & 2 \\
\hline bis(2-Chloroisopropyl)e & $(u g / L)$ & $<11.0000$ & $<10.0000$ & $<10.5000$ & 2 \\
\hline bis(2-Ethylhexyl)phthal & (ug/L) & J 16.0000 & $<8.0000<$ & $<12.0000$ & 2 \\
\hline Chrysene & (ug/L) & $<11.0000$ & $<10.0000$ & $<10.5000$ & 2 \\
\hline Di-n-butylphthalate & (ug/L) & 10.0000 & $<3.0000<$ & $<6.50002$ & 2 \\
\hline Di-n-octylphthalate & $(u g / h)$ & $<11.0000$ & $<10.0000$ & $<10.5000$ & 2 \\
\hline Dibenzo $(a, h)$ anthracene & $(u g / L)$ & $<11.0000$ & $<10.0000$ & $<10.5000$ & 2 \\
\hline Diethy!phthalate & $(u g / L)$ & $<11.0000$ & $<10.0000$ & $<10.5000$ & 2 \\
\hline Dimethylphthalate & $(u g / L)$ & $<11.0000$ & $<10.0000$ & $<10.5000$ & 2 \\
\hline Fluoranthene & (ug/L) & $<11.0000$ & $<10.0000$ & $<10.5000$ & 2 \\
\hline Fluorene & (ug/L) & $<11.0000$ & $<10.0000$ & $<10.5000$ & 2 \\
\hline Hexachlorobenzene & (ug/L) & $<11.0000$ & $<10.0000$ & $<10.5000$ & 2 \\
\hline Hexachlorobutadiene & (ug/L) & $<11.0000$ & $<10.0000$ & $<10.5000$ & 2 \\
\hline Hexachlorocyclopentadie & $(u g / L)$ & $<11.0000$ & $<10.0000$ & $<10.5000$ & 2 \\
\hline Hexachloroethane & $(u g / L)$ & $<11.0000$ & $<10.0000$ & $<10.5000$ & 2 \\
\hline Indeno(1,2,3-cd)pyrene & $(u g / L)$ & $<11.0000$ & $<10.0000$ & $<10.5000$ & 2 \\
\hline Isophorone & $(u g / L)$ & $<11.0000$ & $<10.0000$ & $<10.5000$ & 2 \\
\hline N-Nitroso-di-n-propylam & $(u g / L)$ & $<11.0000$ & $<10.0000$ & $<10.5000$ & 2 \\
\hline N-Nitrosodiphenylamine & $(\mathrm{ug} / \mathrm{L})$ & $<11.0000$ & $<10.0000$ & $<10.5000$ & 2 \\
\hline Naphthalene & $(\operatorname{ug} / L)$ & $<11.0000$ & $<10.0000$ & $<10.5000$ & 2 \\
\hline Nitrobenzene & $(\operatorname{ug} / \mathrm{L})$ & $<11.0000$ & $<10.0000$ & $<10.5000$ & 2 \\
\hline Pentachlorophenol & $(u g / L)$ & $<53.0000$ & $<50.0000$ & $<51.5000$ & 2 \\
\hline Phenanthrene & $(u g / L)$ & J 10.0000 & $<1.0000<$ & $<5.5000$ & 2 \\
\hline Phenol & $(u g / L)$ & $<11.0000$ & $<10.0000$ & $<10.5000$ & 2 \\
\hline Pyrene & $(u g / L)$ & $<11.0000$ & $<10.0000$ & $<10.5000$ & 2 \\
\hline Total Trihalomethanes & $(\mathrm{Ug} / \mathrm{L})$ & 16.0000 & 16.0000 & 16.0000 & \\
\hline 1,1,1-Trichloroethane & $(\omega g / L)$ & $<50000.000$ & $00<8.0000$ & $0<15014.500$ & \\
\hline 1,1,2,2-Tetrechloroetha & $(u g / L)$ & $<10000.000$ & $0<5.0000$ & $0<5002.5000$ & 2 \\
\hline 1,1,2-Trichloroethane & $(\mathrm{ug} / \mathrm{L})$ & 50000.0000 & $0<50.0000$ & $0<38234.2857$ & $\begin{array}{ll}7 & 14\end{array}$ \\
\hline 1.1-Dichloroethane & $(\mathrm{ug} / \mathrm{L})$ & $<50000.000$ & $10<5.0000$ & $0<15013.7500$ & 4 \\
\hline 1,1-Dichloroethene & $(\mathrm{ug} / \mathrm{L})$ & $<50000.000$ & $00<4.0000$ & $00<15013.500$ & 0 \\
\hline 1,2-Dichlorobenzene & $(u g / L)$ & $<11.0000$ & $<10.0000$ & $<10.5000$ & 2 \\
\hline 1,2-Dichloroethane & $(u g / L)$ & $<50000.000$ & $00<5.0000$ & $0<63337.0000$ & 15 \\
\hline 1,2-Dichloroethene & (ug/L) & $<10000.000$ & $00<550.000$ & $200<5275.000$ & \\
\hline 1,2-Dichloropropane & (ug/L) & $<10000.000$ & $30<5.0000$ & $0<5002.5000$ & 2 \\
\hline 1,3-Dichlorobenzene & (ug/L) & $<11.0000$ & $<10.0000$ & $<105000$ & 2 \\
\hline & & nentat & mation M & $\begin{array}{l}\text { zeme } \\
04 / 2\end{array}$ & \\
\hline
\end{tabular}

Analysis

(Units) Maximum Minimum Average Count

1.4-Dichlorobenzene

$(\mathrm{ug} / \mathrm{L})<11.0000<10.0000<10.50002$ 


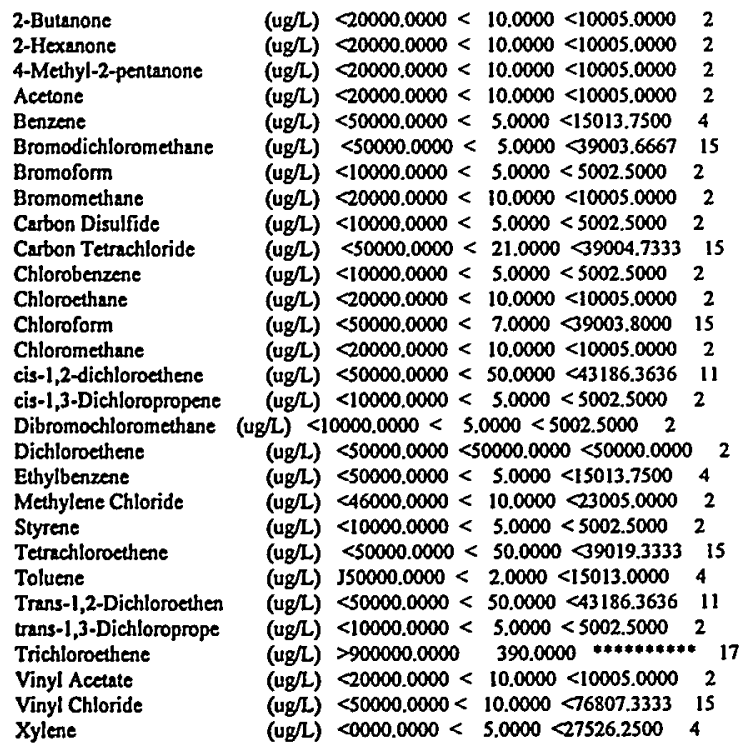




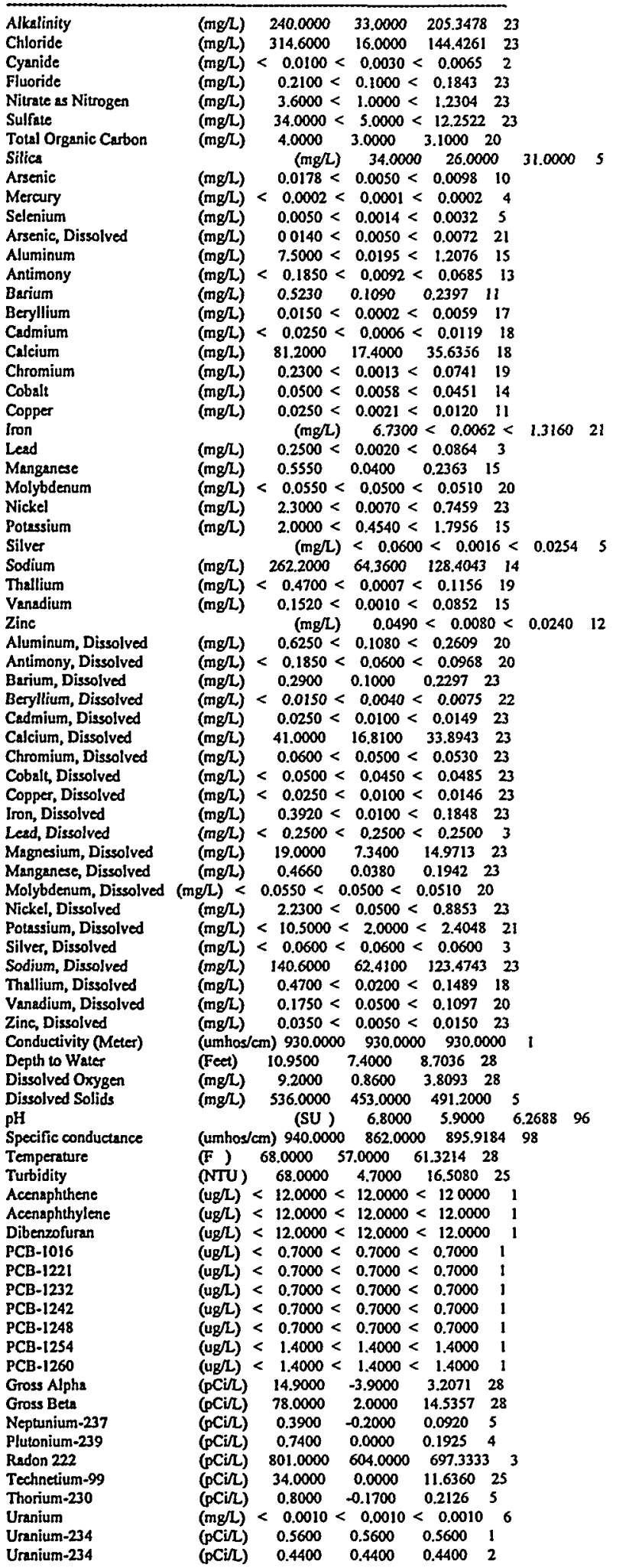




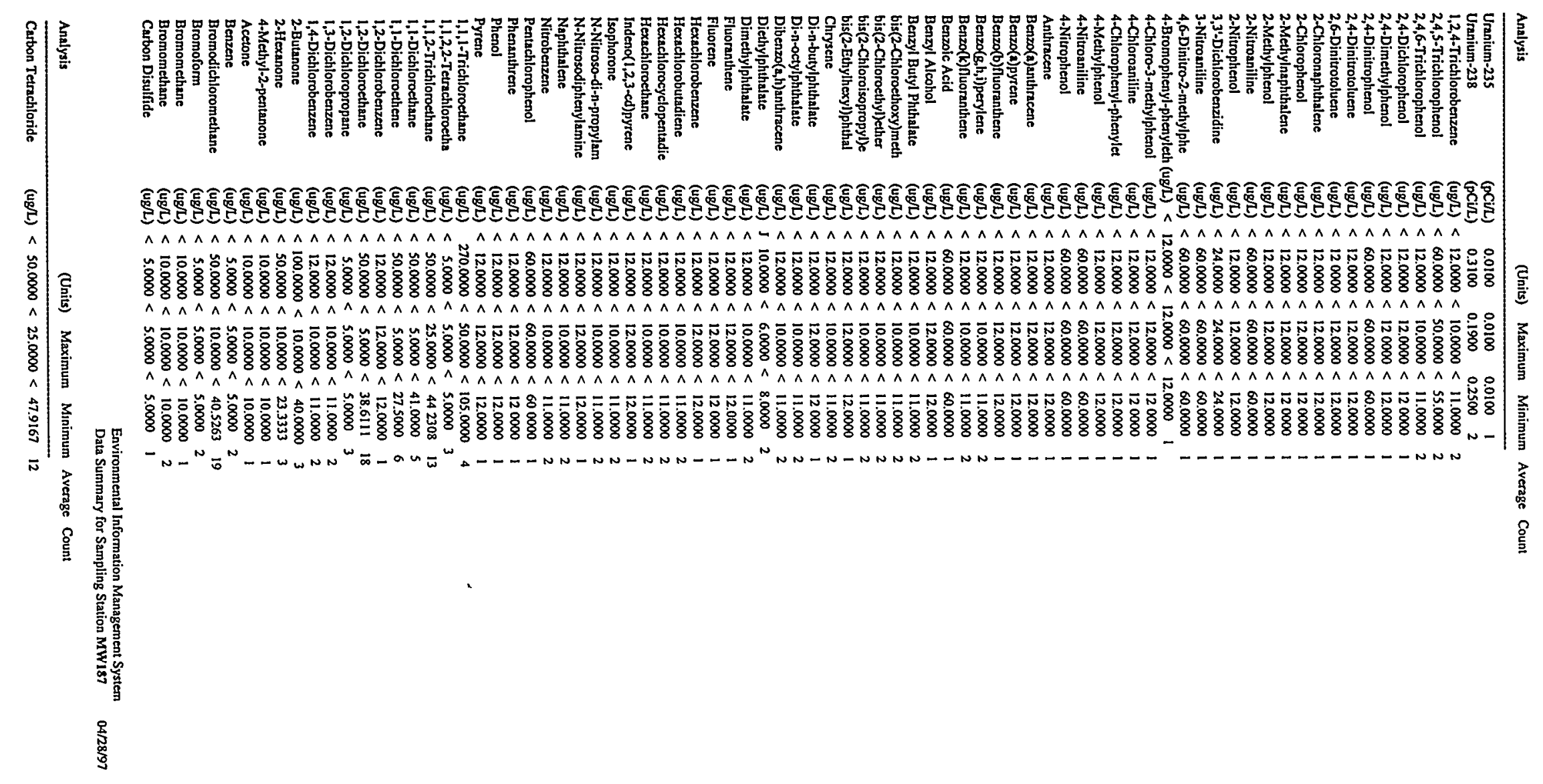




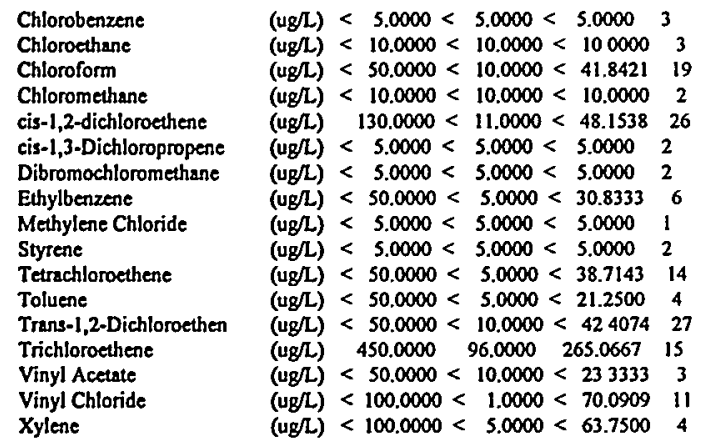




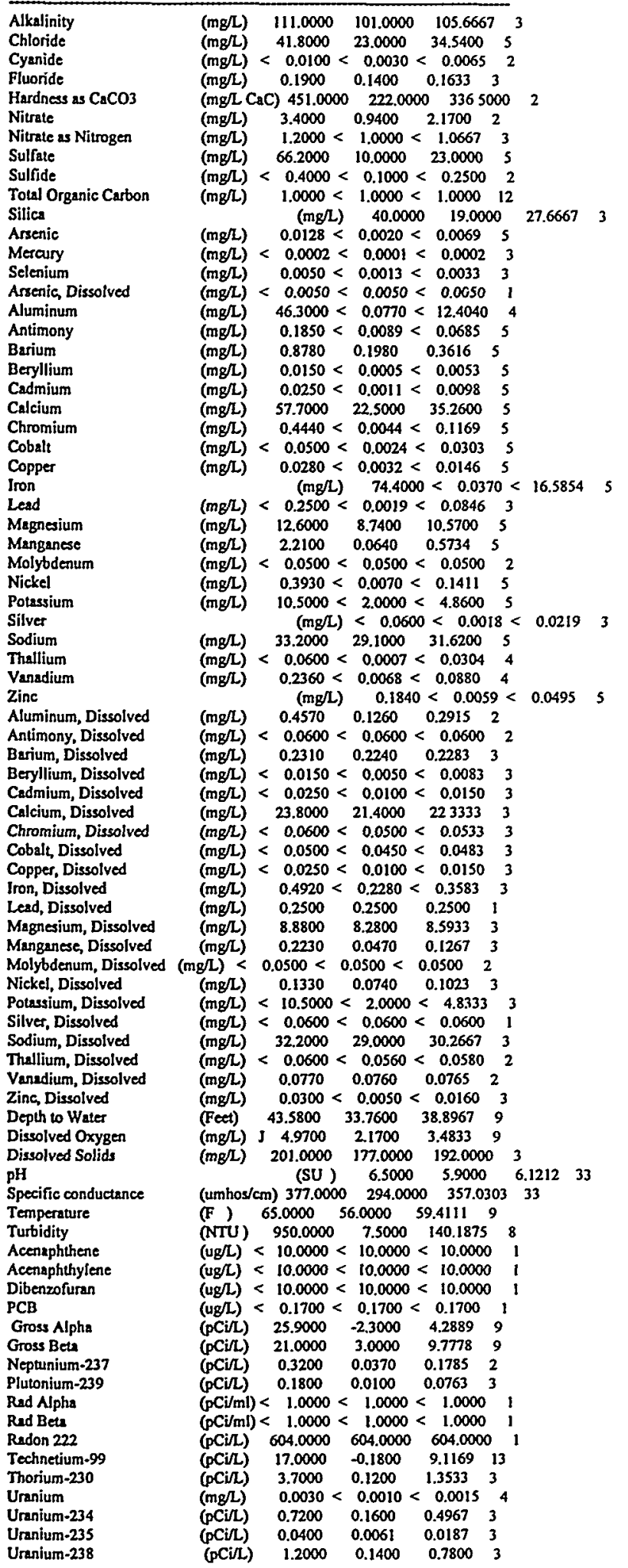




\begin{tabular}{|c|c|c|c|c|c|}
\hline 4-Trichlorobenzene & (ug/L) & $<100000<$ & $100<$ & 00 & \\
\hline Trichlorophenol & $(\mathrm{ug} / \mathrm{L})$ & $<50.0000<$ & $50.0000<$ & 50.0000 & \\
\hline 2,4,6-Trichlorophenol & $\left(u_{g} / L\right)$ & $<10.0000<$ & $10.0000<$ & 10.0000 & \\
\hline 2,4-Dichlorophenol & $(u g / L)$ & $<10.0000<$ & $10.0000<$ & 10.0000 & \\
\hline 4-Dimethylphenol & $g(L)$ & $<10.0000<$ & $10.0000<$ & 10.0000 & \\
\hline 4-Dinit & $g / L)$ & $<50.0000<$ & $50.0000<$ & 50.0000 & \\
\hline 2,4-Dinitrotoluene & $(\operatorname{ug} / L)$ & $<10.0000<$ & $10.0000<$ & 100000 & \\
\hline 2,6-Dinitrotoluene & $(U g / L)$ & $<10.0000<$ & $10.0000<$ & 10.0000 & \\
\hline thalene & $3(L)$ & $<10.0000<$ & $10.0000<$ & 10.0000 & \\
\hline Chlor & $g(L)$ & $<10.0000<$ & $10.0000<$ & 10.0000 & \\
\hline ualene & $(\mathrm{ug} / \mathrm{L})$ & $<10,0000<$ & $10.0000<$ & 10.0000 & \\
\hline 2-Meth & (ug/L) & $<10.0000<$ & $10.0000<$ & 10.0000 & \\
\hline 2-Nitroani & $(u g / L)$ & $<50.0000$ & & 000 & \\
\hline of & $(u g / L)$ & $<10.0000<$ & $10.0000<$ & 000 & \\
\hline enzidine & $(u g / L)$ & $<20.0000$ & 20.0000 & 20.0000 & \\
\hline ne & $(\mathrm{ug} / \mathrm{L})$ & $<50.0000<$ & 50.0000 & 50.0000 & \\
\hline -methylphe & (ug/L) & $<50.0000<$ & $50.0000<$ & 000 & \\
\hline yl-phenylet & $(u g / L)$ & $<10.0000<$ & $10.0000<$ & 10.0000 & \\
\hline no & $(u g / L)$ & $<10.0000<$ & $10.0000<$ & 10.0000 & \\
\hline -Chlc & 2(L) & $<10.0000<$ & $10.0000<$ & 10.0000 & \\
\hline 1-phenylet & (ug/L) & $<10.0000<$ & & 10.0000 & \\
\hline$M$ & $(U g / L)$ & $<10.0$ & $00<$ & 10.0000 & \\
\hline $4-N i$ & $(u g / L)$ & $<50$. & $00<$ & 000 & \\
\hline enol & $(u g / L)$ & $<50.0000<$ & $000<$ & 50.0000 & \\
\hline nun & $(u g / L)$ & $<10.0000<$ & $10.0000<$ & 10.0000 & \\
\hline inthracene & $(U g / L)$ & $<10.0$ & $10.0000<$ & 10 & \\
\hline Benzo(a)pyrene & $(u g / L)$ & $<10.0$ & $10.0000<$ & 10.0000 & \\
\hline Benzo(b) fluoranthene & $(u g / L)$ & $<10$. & $000<$ & 10.0000 & \\
\hline Ben & (ug/L) & $<10.0000<$ & $10.0000<$ & 10.0000 & \\
\hline iene & (ug/L) & $<10$. & $10.0000<$ & 10.0000 & \\
\hline & $g(L)$ & $<50$. & $00<$ & 00 & \\
\hline Ben & $(\mathrm{ug} / \mathrm{L})$ & $<10$. & $00<$ & 200 & \\
\hline Ben & $g / L)$ & $<10$ & $100<$ & 10.0000 & \\
\hline eth & /(L) & $<10.0$ & $10.0000<$ & 10.0000 & \\
\hline & g/L) & $<10.0000<$ & $=10.0000<$ & 10.0000 & \\
\hline bis( & /L) & $<10$ & $00<$ & 000 & \\
\hline bis( & $g(\mathcal{L})$ & $<10$ & $100<$ & 10.0000 & \\
\hline Chrys & 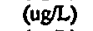 & $<10.0000<$ & $000<$ & 10.0000 & \\
\hline Diet & $g / L)$ & $<10.0$ & $00<$ & 10.0000 & \\
\hline hthalate & (2) & $<10$. & $00<$ & 100 & \\
\hline Dibe & $2(L)$ & $<10$ & $00<$ & 000 & \\
\hline Diet & $g(L)$ & $<10.0$ & $100<$ & 10.0000 & \\
\hline Thtalate & $(u g / L)$ & $<10.0$ & $=10 . c$ & 10.0000 & \\
\hline anthene & $g(L)$ & $<10$ & & $\infty$ & \\
\hline Fl & $g / L)$ & $<10$ & $0<$ & 00 & \\
\hline $\mathbf{H}$ & $g / L)$ & $<10 . C$ & $100<$ & 10.0000 & \\
\hline He & $g / L)$ & $<10$. & $=10$ & 10.0000 & \\
\hline entadie & $(\operatorname{ug} / L)$ & $<10$. & & $=10$. & \\
\hline & $(u g / L)$ & $<10$. & $00<$ & 10.0000 & \\
\hline pyrene & $(u g / L)$ & $<10.0$ & $=10.0000<$ & 10.0000 & \\
\hline Iso & ofL) & $<10.0$ & $<10.0000<$ & $=10.0000$ & 1 \\
\hline troso-di-n-p & $g / L)$ & $<10$ & & $=10.0000$ & 1 \\
\hline diphen & $(u g / L)$ & $<10$. & $\leqslant 10$ & 10.0000 & \\
\hline ene & $(\mathrm{ug} / \mathrm{L})$ & $<10.0$ & $<10.0000<$ & 10.0000 & \\
\hline Nitrobenzene & (ug/L) & $<10.0000<$ & $<10.0000<$ & $=10.0000$ & \\
\hline Pentachlorophenol & $(\operatorname{ug} / \mathrm{L})$ & $<50.0$ & $<50$. & S 50.0000 & 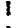 \\
\hline nthrene & $g / L)$ & $<10$ & $30<$ & 200 & \\
\hline Phe & (L) & $<10$. & $<10.0000<$ & 10.0000 & \\
\hline Pyr & $(/ L)$ & $<10.0$ & $<10.0000<$ & 10.0000 & 1 \\
\hline 1,1,1-Trichloroethan & (ug/L) & $<5.0000<$ & $5.0000<$ & 5.0000 & \\
\hline -Tetrachloroetha & & $<5.0$ & $0<$ & 5.0 & 1 \\
\hline ane & & $<5.0$ & $00<$ & 5.0000 & \\
\hline oroet & $g / L)$ & $<5.0000<$ & $5.0000<$ & 5.0000 & \\
\hline 1,1-Dichloroethene & $(\mathrm{ug} / \mathrm{L})$ & $<5.0000<$ & $5.0000<$ & 5.0000 & \\
\hline hlorobenzene & & $<10.0000<$ & $<10.0000<$ & 10.0000 & \\
\hline omethane & & $<5.0$ & $5.0000<$ & 5.0000 & \\
\hline loroethene & g/L) & $<5.0000$ & $5.0000<$ & 5.0000 & \\
\hline 1,2-Dichloropropane & $(\mathrm{g})$ & $<5.0000<$ & $5.0000<$ & 5.0000 & \\
\hline 1,3-Dichloroberizene & & $<10.0000<$ & $<10.0000$ & 10.0000 & \\
\hline f-Dichlorobenzene & & $<10.0$ & $<10.0000$ & 10.0000 & \\
\hline Butanone & ( & $<10.0000<$ & $<10.0000<$ & $<10.0000$ & \\
\hline exanone & $(u g / L)$ & $<10.0000<$ & $<10.0000<$ & $=10.0000$ & \\
\hline 4-Methyl-2-per & & $<10.0000<$ & & 10.0000 & \\
\hline Acrtong & & 32.0 & 32.0000 & 2.0000 & \\
\hline & & $5.0000<$ & $=5.0000<$ & 5.0000 & \\
\hline Bromodichlor & & $5.0000<$ & $1000<$ & 0002 & \\
\hline (n- & & & 5.0000 & 5.0000 & \\
\hline & & $<10.0$ & 10.0 & 10.0000 & \\
\hline & (g/) & $<5.0000<$ & $5.0000<$ & 5.0000 & \\
\hline
\end{tabular}

Carbon Disulfide 


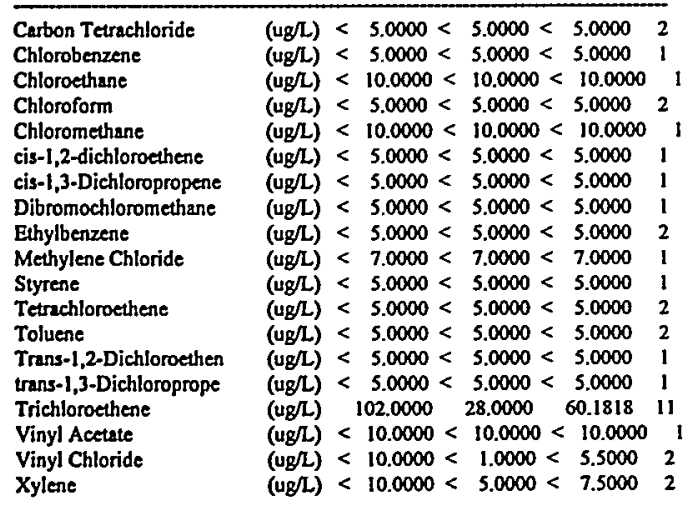


Analysis

(Units) Maximum Minimum Average Count

Alkalinity
Chloride
Cyanide
Fluoride
Hardress as CaCo3
Nitrate
Nitrate as Nitrogen
Sulfate
Sulfide
Total Organic Carbon
Silica
Arsenic
Mercury
Selenium
Aluminum
Antimony
Barium
Beryllium
Cadmium
Calcium
Chromium
Cobalt
Copper
Iron
Lead
Magnesium
Manganese
Molybdenum
Nickel
Potassium
Silicon
Silver
Sodium
Thallium
Vanadium
Zine
Aluminum, Dissolved
Antimonn, Dissolved
Barium, Dissolved
Beryllium, Dissolved
Cadmium, Dissolved
Calcium, Dissolved
Chromium, Dissolved
Cobalt, Dissolved
Copper, Dissolved
Iron, Dissolved
Lead, Dissolved
Magresium, Dissolved
Manganese, Dissolved
Molybdenum, Dissolved
Nickel, Dissolved
Potassium, Dissolved
Silver, Djssolved
Sodium, Dissolved
Thallium, Dissolved
Vanadium, Dissolved
Zing, Dissolved
Depth to Water
Dissolved Oxygen
Dissolved Solids
pH
a

\begin{tabular}{|c|c|c|c|c|}
\hline $\mathrm{ag}$ & 00 & 00 & 58. & \\
\hline & 2.100 & 10.0000 & 20.3857 & \\
\hline & $<0.0200$ & 0.0083 & 0.013 & \\
\hline & 0.1700 & 0.1400 & 0.1533 & \\
\hline & 88.0000 & 2.00 & 780 & $\Omega_{1}$ \\
\hline & & & & 3 \\
\hline & & & & 4 \\
\hline & 11 & 7.0000 & 8.6143 & 7 \\
\hline & 0.1 & 0.0260 & 0.0753 & 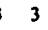 \\
\hline & & 1.0000 & $\begin{array}{r}1.0000 \\
20.0\end{array}$ & \\
\hline
\end{tabular}

$(\mathrm{mg} / \mathrm{L})<\begin{array}{ccccc}(\mathrm{mg} / \mathrm{L}) & 30.0000 & 20.0000 & 24.5000 & 4\end{array}$

$(\mathrm{mg} / \mathrm{L})<0.0002<0.0002<0.00328$

(mgl) $0.0002<0.0002<0.00025$

$\begin{array}{llll}0.0050<0.0010<0.00246 & 6\end{array}$

$(\mathrm{mg} / \mathrm{L})<0.2500<0.0182<0.08038$

$\begin{array}{lllll}(\mathrm{mg} / \mathrm{L}) & 0.2980 & 0.1280 & 0.1603 & 8\end{array}$

$(m g / L)<0.0250<0.0006<0.00678$

$(m g / L)<0.1000<0.0027<0.01988$

$\begin{array}{lllll}(\mathrm{mg} / \mathrm{L}) & 16.4000 & 12.8000 & 14.5500 & 8\end{array}$

(mg/L) $\quad 0.0600<0.0030<0.03117$

(mg/L) $\quad 0.1000<0.0030<0.03448$

(mg/L) $\quad 0.1000<0.0025<0.02398$

$(\mathrm{mg} / \mathrm{L}) \quad 30.0000<0.0370<5.38048$

(mg/L) $\quad 0.2500<0.0018<0.0527$ 5

$\begin{array}{lllll}(\mathrm{mg} / \mathrm{L}) & 7.0800 & 5.8000 & 6.4350 & 8\end{array}$

(mg/L) $\quad 0.8470<0.0120<0.22108$

$(\mathrm{mg} / \mathrm{L})<0.1000<0.0500<0.06673$

$(\mathrm{mg} / \mathrm{L}) \quad 0.1000<0.0039<0.04348$

$(\mathrm{mg} / \mathrm{L}) \quad 10.5000<1.6400<3.64008$

$\begin{array}{lllll}(\mathrm{mg} / \mathrm{L}) & 24.8000 & 7.4600 & 16.1300 \quad 2\end{array}$ (mg/L) $\quad 0.0600<0.0038<0.02096$

$(\mathrm{mg} / \mathrm{L}) \quad 26.7000 \quad 21.3000 \quad 24.0250 \quad 8$

$(\mathrm{mg} / \mathrm{L})<0.0600<0.0014<0.02216$

$(\mathrm{mg} / \mathrm{L}) \quad 0.0620<0.0020<0.03096$

$\begin{array}{lllll} & (\mathrm{mg} / \mathrm{L}) & 0.2500 & <0.0050 & <0.05918\end{array}$

$(\mathrm{mg} / \mathrm{L})<0.1850<0.0600<0.1017$

$\begin{array}{llll}(\mathrm{mg} / \mathrm{L}) & 0.1280 & 0.1140 & 0.1210 \quad 4\end{array}$

$(\mathrm{mg} / \mathrm{L})<0.0150<0.0050<0.00833$

$(\mathrm{mg} / \mathrm{L})<0.0250<0.0100<0.01503$

$\begin{array}{lllll}(\mathrm{mg} / \mathrm{L}) & 14.1000 & 13.0000 & 13.5000 & 3\end{array}$

$(\mathrm{mg} / \mathrm{L})<0.0600<0.0500<0.05333$

$(\mathrm{mg} / \mathrm{L})<0.0500<0.0450<0.04833$

$(\mathrm{mg} / \mathrm{L})<0.0250<0.0100<0.01503$

(mg/l) $0.02550<0.0170<0.13203$

$\begin{array}{lllll}(\mathrm{mg} / \mathrm{L}) & 6.2200 & 5.8000 & 5.9933 \quad 3\end{array}$

$(\mathrm{mg} / \mathrm{L}) \quad 0.0240<0.0150<0.01973$

$(\mathrm{mg} / \mathrm{L})<0.0500<0.0500<0.05002$

$(\mathrm{mg} / \mathrm{L}) \quad 0.1000<0.0500<0.07 .73$

$(\mathrm{mg} / \mathrm{L})<10.5000<2.0000<4.83333$

$(\mathrm{mg} / \mathrm{L})<0.0600<0.0600<0.0600 \quad 1$

$\begin{array}{lllll}(\mathrm{mg} / \mathrm{L}) & 25.3000 & 22.3000 & 23.5000 & 3\end{array}$

$(\mathrm{mg} / \mathrm{L})<0.0600<0.0600<0.06002$

$(m g / L) \quad 0.0550<0.0500<0.05252$

$(\mathrm{mg} / \mathrm{L})<0.0300<0.0050<0.01433$

$\begin{array}{llll}\text { (Feet) } \quad 32.1400 & 23.0800 & 27.6089 & 9\end{array}$

$\begin{array}{lllll}(\mathrm{mg} / \mathrm{L}) & 8.3700 & 4.3200 & 6.1756 \quad 9\end{array}$

$\begin{array}{llll}(\mathrm{mg} / \mathrm{L}) & 143.0000 & 131.0000 & 136.5000\end{array}$

$\begin{array}{lrrrrr}(\mathrm{mg} / \mathrm{L}) & 143.0000 & 131.0000 & 136.5000 & 4 & \\ & \text { (SU) } & 6.2000 & 6.0000 & 6.0485 & 33\end{array}$

$\begin{array}{llll}\text { (umhos } / \mathrm{cm} \text { ) } 253.0000 & 211.0000 & 239.2121 & 33\end{array}$

(F) $\quad \begin{array}{llll}62.0000 & 57.0000 & 58.4222 & 9\end{array}$

$\begin{array}{lllll}\text { (mg/L) } & 8.0000 & 8.0000 & 8.0000 & 1\end{array}$

(NTU) 120.0000

(ug/L) $<11.0000<10.0000<10.3333$

$(\mathrm{ug} / \mathrm{L})<11.0000<10.0000<10.33333$

$(\mathrm{ug} / \mathrm{L})<11.0000<10.0000<10.33333$

$(\mathrm{ug} / \mathrm{L})<0.1700<0.1700<0.1700 \quad 1$

$\begin{array}{lllll}(\mathrm{pCi} / \mathrm{L}) & 7.6000 & -2.1000 & 2.0556 & 9\end{array}$

$\begin{array}{lllll}(\mathrm{pCi} / \mathrm{L}) & 17.0000 & 1.0000 & 6.7778 & 9\end{array}$

$\begin{array}{lllll}(\mathrm{pCi} / \mathrm{L}) & 0.5000 & -0.5500 & -0.0133 & 3\end{array}$

(pCiл) $0.1500 \quad 0.0160 \quad 0.09873$

(pCiL) 0.15000 .016000 .09873

$(\mathrm{pCi} / \mathrm{ml})<1.0000<1.0000<1.0000$

$(\mathrm{pCi} / \mathrm{ml})<1.0000<1.0000<1.00001$

(pCi/L) $\quad 437.0000 \quad 239.0000 \quad 338.0000 \quad 2$

$\begin{array}{lllll}\text { (pCi/L) } & 17.0000 & 0.0000 & 7.7258 & 12 \\ \text { (pCi } / \text { ) } & 0.2200 & -0.3400 & -0.0503 & 3\end{array}$

(mell) $<0.0010<0.0010<0.0010<4$

$\begin{array}{lllll}(\mathrm{pCi} / L) & 6.8000 & 0.0100 & 4.0700 & 3\end{array}$

$\begin{array}{lllll}\text { (pCilL) } & 0.4200 & 0.0200 & 0.2233 & 3\end{array}$ 
Uranium-238

1,2,4-Trichlorobenzene

2,4,5-Trichlorophenol

2,4,6-Trichloropheno

2,4-Dichlorophenol

2,4-Dinitrophenol

2,4-Dinitrotoluene

2,6-Dinitrotoluene

2-Chloronaphthalene

2-Chlorophenol

2-Methyinaphthalene

2-Methylphenol

2-Nitroaniline

2-Nitrophenol

3,3'-Dichlorobenzidine

3-Nitroaniline

4,6-Dinitro-2-methylphe

4-Bromophenyl-phenyle

4-Chloro-3-methylphenol

4-Chloroaniline

4-Chlorophenyl-phenylet

4-Methylphenol

4-Nitroaniline

4-Nitrophenol

Anthracene

Benzo(a)anthracene

Benzo(a)pyrene

Benzo(b) nuoranthene

$\operatorname{Benzo}(\mathrm{g}, \mathrm{h}, \mathrm{i})$ perylene

Benzo(k)fluoranthene

Benzoic Acid

Benzyl Alcohol

Benzyl Butyl Phthalate

bis(2-Chloroethoxy)meth

bis(2-Chloroethyl)ether

bis(2-Chloroisopropyl)e

bis(2-Ethylhexyl)phthal

Chrysene

Di-n-butylphthalate

Di-n-octylphthalate

Dibenzo(a,b)anthracene

Diethylphthal ate

Dimethylphthalate

Fluoranthene

Fluorene

Hexachlorobenzene

Hexachlorobutadiene

Hexachlorocyclopentadie

Hexachloroethane

Indeno( $1,2,3-e d)$ pyrene

Isophorone

N-Nitroso-di-n-propylam

N-Nitrosodiphenylamine

Naphthalene

Nitrobenzene

Pentschlorophenol

Phenanthrene

Phenol

Pyrene

1,1,1-Trichloroethane

1,1,2,2-Tetrachloroeth

1,1,2-Trichloroethane

1,1-Dichloroethane

1.1-Dichloroethene

1,2-Dichlorobenzene

1,2-Dichloroethane

1,2-Dichloroethene

1,2-Dichloropropane

1,3-Dichlorobenzene

1,4-Dichlorobenzene

2-Butanone

2-Hexanone

4-Methyl-2-pentanone

Acetone

Benzene

Bromodichloromethane

Bromoform

Bromomethane

Camon Disulfide

Carbon Tetrachloride
2,4-Dimethylphenol

$\begin{array}{lllll}\text { (pCi/L) } & 9.0000 & 0.0100 & 4.9033 & 3\end{array}$

$(\mathrm{ug} / \mathrm{L})<11.0000<10.0000<10.33333$

(ug/L) $<54.0000<50.0000<51.33333$

$($ ug $/ \mathrm{L})<11.0000<10.0000<10.3333$

$(\mathrm{ug} / \mathrm{L})<11.0000<10.0000<10.3333$

$(\mathrm{ug} / \mathrm{L})<11.0000<10.0000<10.3333$

$(\mathrm{ug} / \mathrm{L})<540000<50.0000<51.33333$

$(u g / L)<11.0000<10.0000<10.33333$

$(\mathrm{ug} / \mathrm{L})<11.0000<10.0000<1033333$

$(\mathrm{ug} / \mathrm{L})<11.0000<10.0000<103333$

(ug/L) $<11.0000<10.0000<1033333$

(ug/L) $<11.0000<10.0000<10.33333$

(ug/L) $<11.0000<10.0000<10.33333$

$(u / L)<11.0000<10.0000<10.3333$

ug $/ \mathrm{L})<54.0000<50.0000<51.3333$

$(\mathrm{ug} / \mathrm{L})<11.0000<10.0000<10.3333$

$(u g / L)<22.0000<20.0000<20.66673$

(ug/L) $<54.0000<50.0000<51.33333$

$(\mathrm{ug} / \mathrm{L})<54.0000<50.0000<51.33333$

(ug/L) $<11.0000<10.0000<10.33333$

$(\omega g / L)<11.0000<10.0000<10.3333$

(48/L) $<11.0000<10.0000<10.3333$

(198) $<11.0000<10.0000<10$.

$(\mathrm{ug} / \mathrm{L})<11.0000<10.0000<10.3333$

$(u g / L)<54.0000<50.0000<51.3333$

$(u g / L)<54.0000<50.0000<51.33333$

$(40 / L)<11.0000<10.0000<10.3333$

$(\mathrm{ug} / \mathrm{L})<11.0000<10.0000<10.3333$

$(\mathrm{ug} / \mathrm{L})<11.0000<10.0000<10.33333$

$(\mathrm{ug} / \mathrm{L})<11.0000<10.0000<10.33333$

(ug/L) $<11.0000<10.0000<10.33333$

$(\mathrm{ug} / \mathrm{L})<11.0000<10.0000<10.33333$

$(u g / L)<54.0000<50.0000<51.3333$

(48/L) $<11.0000<10.0000<10.33333$

(1) $<1.0000<10.0000<10.33$

(ug/L) $<11.0000<10.0000<10.3333$

ug/L) $<11.0000<10.0000<10.3333$

$(\mathrm{ug} / \mathrm{L})<11.0000<10.0000<10.33333$

(ug/L) J $9.0000 \quad 4.0000 \quad 7.3333 \quad 3$

$(\mathrm{ug} / \mathrm{L})<11.0000<10.0000<10.3333$

$(\mathrm{ug} / \mathrm{L})$ ) $11.0000<1.0000<4.66673$

$(\mathrm{ug} / \mathrm{L})<11.0000<10.0000<10.33333$

(ug/L) $<11.0000<10.0000<10.3333$

$(\mathrm{ug} / \mathrm{L})<11.0000<10.0000<10.3333$

$(\mathrm{ug} / \mathrm{L})<11.0000<10.0000<10.33333$

(ug/L) $<11.0000<10.0000<10.3333$

(ug/L) $<11.0000<10.0000<10.3333$

(4.1) $<11.0000<10.0000<10.33$.

$($ ug/L) $<11.0000<10.0000<10.33333$

$(\mathrm{ug} / L)<11.0000<10.0000<10.33333$

$(\mathrm{ug} / \mathrm{L})<11.0000<10.0000<10.3333$

$(4 \mathrm{~g} / \mathrm{L})<11.0000<10.0000<103333$

$(\mathrm{ug} / \mathrm{L})<11.0000<10.0000<1033333$

$(u g / L)<11.0000<10.0000<10.33333$

(ug/L) $11.0000<2.0000<7.66673$

$(\mathrm{ug} / \mathrm{L})<11.0000<10.0000<10.3333$

(ug/L) $<11.0000<10.0000<10.3333$

(ug/L) $<54.0000<50.0000<51.3333$

$(40 / L)<11.0000<10.0000<10.3333$

$(4 \mathrm{~g})<1<1$

$(u g / L)<11.0000<10.0000<10.3333$

$(\mathrm{ug} / \mathrm{L})<11.0000<10.0000<10.33333$

(ug/L) $<5.0000<5.0000<5.00004$

$(\mathrm{ug} / \mathrm{L})<5.0000<5.0000<5.00003$

(ug/L) $<5.0000<5.0000<5.00004$

(ug/L) $<5.0000<5.0000<5.00004$

$(4 \mathrm{~g} / \mathrm{L})<5.0000<5.0000<5.00004$

$(\mathrm{Lg} / \mathrm{L})<11.0000<10.0000<10.3333$

(ug/L) $<5.0000<5.0000<5.00004$

(ug/L) $<5.0000<5.0000<5.00003$

ugh) $<5.0000<5.0000<5.00003$

$(\mathrm{ug} / \mathrm{L})<11.0000<10.0000<10.33333$

(ug/L) $<11.0000<10.0000<10.3333$

$(u g / L)<10.0000<10.0000<10.00003$

$(\mathrm{ug} / \mathrm{L})<10.0000<10.0000<10.00003$

$(u g / L)<10.0000<10.0000<10.00003$

(ug/L) $<10.0000<10.0000<10.0000$

(ug/L) $<5.0000<5.0000<5.00004$

$(u g / L)<5.0000<5.0000<5.00004$

$(4 \mathrm{~g})<5.0000<5.0000<5.00003$

(4. $<10.0000<10.0000<10.00003$

$(u g / L)<5.0000<5.0000<5.00003$

(ug/L) $<5.0000<5.0000<5.00004$

Environmental Information Management System

Data Summary for Sampling Station MW194 04/28/97 
Chlorobenzene

Chlorocthane

Chloroform

Chloromethane

cis-1,2-dichloroethene

cis-1,3-Dichloropropene

Dibromochloromethane

Ethylbenzene

Methylene Chloride

Styrene

Tetrachloroethene

Toluene

Trans-1,2-Dichloroethen

trans-1,3-Dichloroprope

Trichloroethene

Vinyl Acetate

Vinyl Chloride

Xylene $(\mathrm{ug} / \mathrm{L})<5.0000<5.0000<500003$

$(u g / L)<10.0000<10.0000<100000$

$(\mathrm{ug} / \mathrm{L})<5.0000<5.0000<5.00004$

(ug/L) $<10.0000<10.0000<10.0000$

$(\mathrm{ug} / \mathrm{L})<5.0000<5.0000<5.00001$

(ug/L) $<5.0000<5.0000<5.00003$

(ug/L) $<5.0000<5.0000<5.0000$
(ug/L) $<5.0000<5.0000<5.00003$

(ug/L) $<5.0000<5.0000<5.0000$

$(\mathrm{ug} / \mathrm{L})<5.0000<5.0000<5.0000$

$(\mathrm{ug} / \mathrm{L})<5.0000<5.0000<5.00003$

(ug/l) $<5.0000<5.0000<5.0000$

ug $/ L)<5.0000<5.0000<5.0000$

(ug/L) $<5.0000<5.0000<5.0000$

(ug/L) $<5.0000<5.0000<5.0000$

(ug/L) $<5.0000<5.0000<5.00003$

$(\mathrm{ug} / \mathrm{L})<5.0000<1.0000<1.333312$

$(\mathrm{ug} / \mathrm{L})<10.0000<10.0000<10.00003$

(ug/L) $<10.0000<1.0000<5.50004$

$(\mathrm{ugL})<10.0000<5.0000<6.25004$ 
Environmental Information Management System

Data Summary for Sampling Station MW233 04/28/97

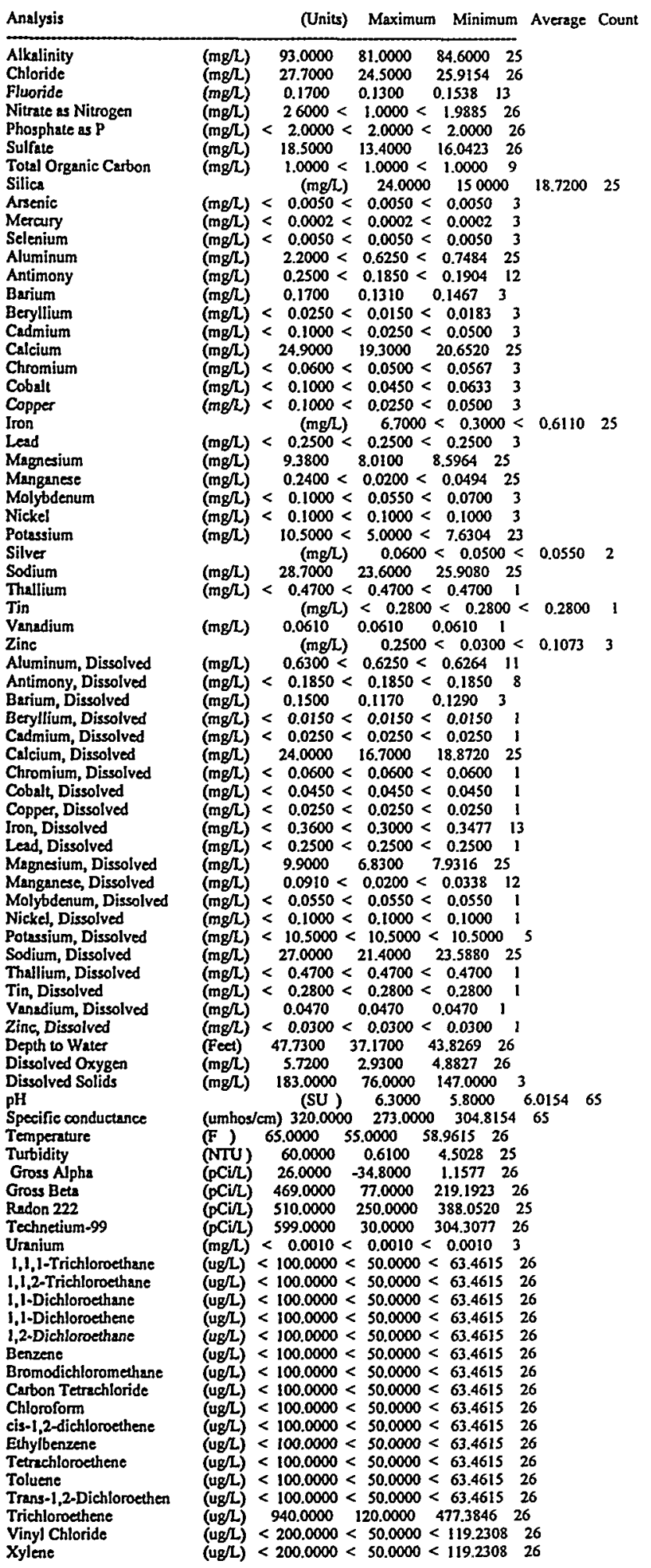




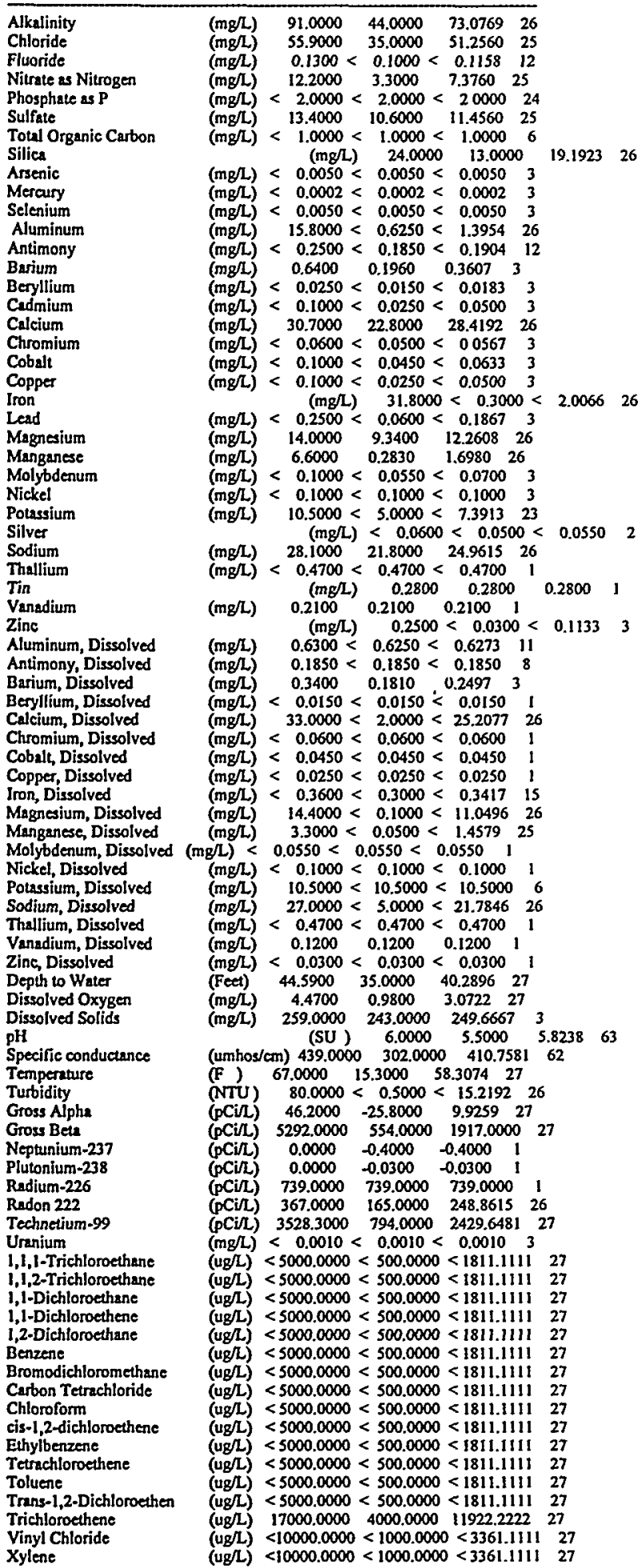




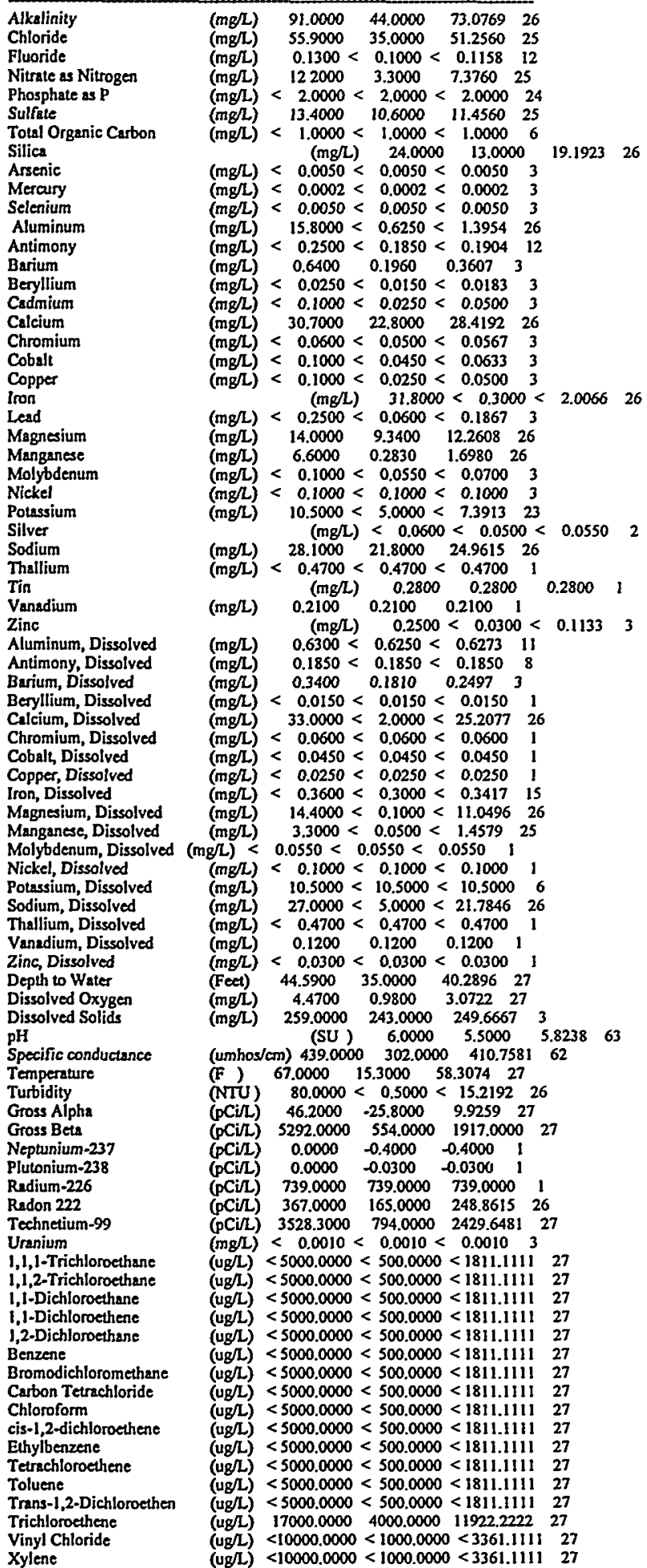


$(m g / L)<2.0000<2.0000<20000$

$\begin{array}{lllll}(\mathrm{mg} / \mathrm{L}) & 34.4000 & 32.6000 & 33.3750 & 4\end{array}$

$(\mathrm{mg} / \mathrm{L}) \quad 2.0000<1.0000<1.3077 \quad 13$ $\begin{array}{lllll}(\mathrm{mg} / \mathrm{l}) & 19.0000 & 13.0000 & 16.7500 \quad 4\end{array}$

Silica.

Arsenic

Mercury

Selenium

Aluminum

Antimony

Barium

Beryllium

Cadmium

Calcium

Chromium

Cobalt

Copper

Iron

Lead

Magnesium

Manganese

Molybdenum

Nickel

Silver

Sodium

Antimony, Dissolved

Burium, Dissolved

Beryllium, Dissolved

Cadmium, Dissolved

Colcium, Dissolved

Calcium, Dissolved

Chromium, Dissolved

Cobalt, Dissolved

Copper, Dissolved

Iron, Dissolved

Lead, Dissolved

Magnesium, Dissolved

Manganese, Dissolved

Nickel, Dissolved

Potassium, Dissolved

Silver, Dissolved

Sodium, Dissolved

Uranium, Dissolved

Zinc, Dissolved

Depth to Water

Dissolved Oxygen

Dissolved Solids

pH

Specific conductance

Temperature

Turbidity

PCB

Gross Alpha

Gross Beta

Radon 222

Technetium-99

Uranium

1,1,1-Trichloroethane

1,1,2-Trichlorethane

1,1-Dichlorocthane

1,1-Dichloroethene

1,2-Dichloroethane

Benzene

Bromodichloromethane

Carbon Tetrachloride

Chloroform

cis-1,2-dichloroethene

Ethylbenzene

Tetrachloroethene

Toluene

Trans-1,2-Dichloroethen

Trichloroethene

Vinyl Chloride

$(\mathrm{mg} / \mathrm{L})<0.0050<0.0050<0.00504$

(mg/L) $\quad 0.0002<0.0002<0.00024$

$(\mathrm{mg} / \mathrm{L})<0.0050<0.0050<0.0050$

(mg/L) $<0.7500<0.7500<0.7500 \quad 1$

$(\mathrm{mg} / \mathrm{L})<0.2500<0.1850<0.20134$

$\begin{array}{lllll}\text { (mg/L) } & 0.3600 & 0.2110 & 0.2575 & 4\end{array}$

$(m g / L)<0.0250<0.0150<0.0175$

$(\mathrm{mg} / \mathrm{L})<0.1000<0.0250<0.04384$

$\begin{array}{lllll}(\mathrm{mg} / \mathrm{L}) & 32.6000 & 29.2000 & 31.2750 & 4\end{array}$

(mg/L) $\quad 0.0600<0.0500<0.05754$

$(\mathrm{mg} / \mathrm{L})<0.1000<0.0450<0.05884$

(mg/L) $0.1000<0.0250<0.04504$

$\begin{array}{lllll}(\mathrm{mg} / \mathrm{L}) & 14.9000 & 0.7720 & 5.2155 & 4\end{array}$

$(\mathrm{mg} / \mathrm{L})<0.2500<0.2500<0.2500$ \&

$\begin{array}{lllll}(m g / L) & 13.5000 & 12.6000 & 13.0000 & 4\end{array}$

$\begin{array}{lllll}(m g / L) & 0.9600 & 0.2170 & 0.5140 & 4\end{array}$

$(m g / L)<0.1000<0.1000<0.10001$

$(\mathrm{mg} / \mathrm{L}) \quad 0.1400<0.1000<0.11004$

$(\mathrm{mg} / \mathrm{L}) \quad 10.5000<5.0000<8.66673$

$(\mathrm{mg} / \mathrm{L})<0.0600<0.0500<0.05754$

$\begin{array}{llll}87.4000 \quad 77.4000 \quad 83.2250 \quad 4 & 4\end{array}$

(mgl) $0.2500<0.0630<0.1270$

$(m g / L)<0.1850<0.1850<0.18502$

$\begin{array}{lllll}(\mathrm{mg} / \mathrm{L}) & 0.2000 & 0.1750 & 0.1853 & 4\end{array}$

$(\mathrm{mg} / \mathrm{L})<0.0150<0.0150<0.01503$

$(m g / L)<0.0250<0.0250<0.02503$

(mell) $30.3000<27.600029 .2500$

(mell) $<30.3000027 .6000<29.2500<4$

(mg/L) $<0.0600<0.0600<0.06003$

$(\mathrm{mg} / \mathrm{L})<0.0450<0.0450<0.04503$

$(m g / L)<0.0250<0.0250<0.02503$

(mg/L) $<0.3550<0.3000<0.34134$

$(\mathrm{mg} / \mathrm{L})<0.2500<0.2500<0.25003$

$\begin{array}{lllll}(m g / L) & 12.4000 & 11.8000 & 12.0750 & 4\end{array}$

$\begin{array}{llllll}(\mathrm{mg} / \mathrm{L}) & 0.3600 & 0.1430 & 0.2818 & 4\end{array}$

$(\mathrm{mg} / \mathrm{L})<0.1000<0.1000<0.10003$

$(\mathrm{mg} / \mathrm{L}) \quad 10.5000<10.5000<10.50003$

$(\mathrm{mg} / \mathrm{L}) \quad 0.0600<0.0600<0.06003$

$\begin{array}{lllll}(\mathrm{mg} / \mathrm{L}) & \mathbf{7 9 . 4 0 0 0} & \mathbf{7 0 . 8 0 0 0} & \mathbf{7 4 . 6 5 0 0} & 4\end{array}$

$(\mathrm{mg} / \mathrm{L})<0.0010<0.0010<0.0010$

(mg/L) $0.0700<0.0300<0.05173$

$\begin{array}{lllll}\text { (Feet) } \quad 58.3300 & 34.5100 & 53.0189 & \end{array}$

$\begin{array}{lllll}(\mathrm{mg} / \mathrm{L}) & 1.2100 & 0.4400 & 0.7722 & 9\end{array}$

$\begin{array}{lllll}(\mathrm{mg} / \mathrm{L}) & 440.0000 & 374.0000 & 408.0000 \quad 4\end{array}$ $\begin{array}{llll}\text { SU ) } \quad 6.2000 & 5.7000 & 6.0476 & 21\end{array}$

(umhos $/ \mathrm{cm}$ ) $729.0000 \quad 689.0000 \quad 701.6500 \quad 20$

(F) $\quad 71.0000 \quad 59.0000 \quad 62.2222 \quad 9$

(NTU) $210.0000 \quad 20.0000 \quad 68.1667 \quad 6$

$(\mathrm{ug} / \mathrm{L})<0.1700<0.1700<0.1700 \quad 1$

$\begin{array}{llll}(\mathrm{DCi} / \mathrm{L}) & 5.5000 & -5.3000 & 0.0778\end{array}$

$\begin{array}{lllll}(\mathrm{pC} i \Omega) & 17.0000 & 0.0000 & 8.0000 & 9\end{array}$

$\begin{array}{lllll}(\mathrm{pC} / 2 / 2) & 584.0000 & 455.0000 & 512.3333 & 3\end{array}$

$\begin{array}{lllll}(\mathrm{pCi} / \mathrm{L}) & 25.0000 & 0.0000 & 11.1111 & 9\end{array}$

$(\mathrm{mg} / \mathrm{L}) \quad 0.0010<0.0010<0.00104$

$(48 / L)<500.0000<100.0000<368.7500$

$(\mathrm{ug} / \mathrm{L})<500.0000<100.0000<368.75008$

$(\mathrm{ug} / \mathrm{L})<500.0000<100.0000<368.75008$

(ug/L) $<500.0000<100.0000<368.75008$

$(u g / L)<500.0000<100.0000<368.75008$

$(u g / L)<500.0000<100.0000<368.7500$

$(\mathrm{He} / \mathrm{L})<500.0000<100.0000<368.75008$

(ug/L) $<500.0000<100.0000<368.7500$

(ug/L) $<500.0000<100.0000<368.7500$

(ug/L) $<500.0000<100.0000<368.7500$

(ug/L) $<500.0000<100.0000<368.7500$

(ug/L) $<500.0000<100.0000<368.7500$

$(\mathrm{ug} / \mathrm{L})<500.0000<100.0000<368.75008$

(ug/L) $<500.0000<100.0000<368.75008$

(ug) $<500.0000<100.0000<368.7500 \quad 8$

$(\mathrm{ug} / \mathrm{L})<1000.0000<100.0000<725.0000 \quad 8$

$(\omega g / L)<1000.0000<100.0000<725.00008$ 


Alkalinity
Chloride
Fluoride
Nitrate as Nitrogen
Sulfate
Total Organic Carbon
Silica
Arsenic
Mercury
Selenium
Antimony
Barium
Beryllium
Cadmium
Calcium
Chromium
Cobalt
Copper
Iron
Lead
Magnesium
Manganese
Nickel
Potassium
Silver
Sodium
Zine

$\begin{array}{lllll}(\mathrm{mg} / \mathrm{l}) & 99.0000 & 83.0000 & 91.0000 & 2\end{array}$

$\begin{array}{lllll}(\mathrm{mg} / \mathrm{L}) & 119.4000 & 76.9000 & 981500 & 2\end{array}$

(mg/L) $\quad 0.1200<0.1000<0.11002$

$\begin{array}{lllll}(m g / L) & 6.8000 & 5.5000 & 6.1500 & 2\end{array}$

$\begin{array}{lllll}(\mathrm{mgl}) & 6.8000 & 5.5000 & 6.1500 & 2 \\ (\mathrm{mgl}) & 37.1000 & 10.8000 & 23.9500 & 2\end{array}$

$(\mathrm{mg} / \mathrm{L})<1.0000<1.0000<1.00008$

$\begin{array}{lllll}(\mathrm{mg} / \mathrm{L}) & 20.0000 & 17.0000 & 185000 & 2\end{array}$

$(\mathrm{mg} / \mathrm{L})<0.0050<0.0050<0.00502$

(mg/L) $\quad 0.0002<0.0002<0.00022$

$(\mathrm{mg} / \mathrm{L})<0.0050<0.0050<0.00502$

$(\mathrm{mg} / \mathrm{L})<0.1850<0.1850<0.18502$

$\begin{array}{lllll}(\mathrm{mg} / \mathrm{L}) & 0.2900 & 0.2330 & 0.2615 & 2\end{array}$

$(\mathrm{mg} / \mathrm{L})<0.0150<0.0150<0.01502$

$(\mathrm{mg} / \mathrm{L})<0.0250<0.0250<0.02502$

$\begin{array}{lllll}(\mathrm{mg} / \mathrm{L}) & 37.1000 & 31.2000 & 34.1500 & 2\end{array}$

$(\mathrm{mg} / \mathrm{L})<0.0600<0.0600<0.06002$

$(\mathrm{mg} / \mathrm{L})<0.0450<0.0450<0.04502$

$(\mathrm{mg} / \mathrm{L})<0.0250<0.0250<0.02502$

$\begin{array}{llllll} & (\mathrm{mg} / \mathrm{L}) & 10.1000 & 0.3550 & 52275 & 2\end{array}$

(m)
$0.2500<0.2500<0.25002$

$\begin{array}{llll}15.6000 & 13.9000 & 14.7500 & 2\end{array}$

$\begin{array}{lllll}(m g / L) & 1.7000 & 0.0590 & 0.8795 & 2\end{array}$

(mgl) $0.2010<0.1000<0.15052$

$(\mathrm{mg} / \mathrm{L})<10.5000<10.5000<10.5000 \quad 1$ $(\mathrm{mg} / \mathrm{L})<0.0600<0.0600<006002$

$(\mathrm{mg} / \mathrm{L}) \quad 61.7000 \quad 36.0000 \quad 48.8500 \quad 2$ $\begin{array}{lllll}(\mathrm{mg} / \mathrm{L}) & 0.0780 & 0.0600 & 0.0690 & 2\end{array}$

Antimony, Dissolved $\quad(\mathrm{mg} / \mathrm{L})<0.1850<0.1850<0.18502$

$\begin{array}{llllll}\text { Barium, Dissolved } & (\mathrm{mg} / \mathrm{L}) & 0.2400 & 0.2220 & 0.2310 & 2\end{array}$

Beryllium, Dissolved $\quad(\mathrm{mg} / \mathrm{L})<0.0150<0.0150<0.01502$

Cadmium, Dissolved $\quad(m g l)<0.0250<0.0250<0.02502$

$\begin{array}{llllll}\text { Calcium, Dissolved } & (\mathrm{mg} / \mathrm{L}) & 33.1000 & 30.6000 & 31.8500 & 2\end{array}$

Chromium, Dissolved $\quad(\mathrm{mg} / \mathrm{L}) \quad 0.0600<0.0600<0.06002$

Cobalt, Dissolved $\quad(\mathrm{mg} / \mathrm{L})<0.0450<0.0450<0.04502$

Copper, Dissolved $\quad(m g /)<0.0250<0.0250<0.02502$

Conper, Dissolved

Lead, Dissolved

Magnesium, Dissolved

Manganese, Dissolved

Nickel, Dissolved

Potassium, Dissolved

Silver, Dissolved

Sodium, Dissolved

Zinc, Dissolved

Depth to Water

Dissolved Oxygen

Dissolved Solids

$\mathrm{pH}$

Specific conductance

Temperature

Turbidity

PCB

Gross Alpha

Gross Beta

Technetium-99

Uranium

1,1,1-Trichloroethase

1,1,2-Trichloroethane

l,1-Dichloroethane

1,1-Dichloroethene

1,2-Dichloroethane

Benzene

Bromodichloromethan

Carbon Tetrachloride

Chloroform

cis-1,2-dichloroethene

Ethylbenzene

Tetrachloroethene

Toluene

Trans-1,2-Dichloroethen

Trichloroethene

Vinyl Chloride

Xylene

$(\mathrm{mg} / \mathrm{L})<0.3550<0.3550<0.35502$

$(\mathrm{mg} / \mathrm{L})<0.2500<0.2500<0.25002$

$\begin{array}{lllll}(\mathrm{mg} / \mathrm{L}) & 13.6000 & 13.6000 & 13.6000 & 2\end{array}$

$\begin{array}{lllll}(m / L) & 1.3600 & 0.0560 & 0.7080 & 2\end{array}$

$(\mathrm{mg} / \mathrm{l}) \quad 0.2090<$

(mg/L) $\quad 10.5000<10.5000<10.5000$

$(m g / L) \quad J<0.0600<0.0600<0.0600$

$(\mathrm{mg} / \mathrm{L}) \quad 53.7000 \quad 34.6000 \quad 44.1500 \quad 2$

(mg/L) $0.0700<0.0300<0.05002$

$\begin{array}{llll}\text { (Feet) } \quad 48.4000 & 42.8300 & 45.9071 & 7\end{array}$

$\begin{array}{lllll}\text { (mg/L) } & 3.7900 & 1.7900 & 2.8329 & 7\end{array}$

$\begin{array}{llll}(m g / L) & 350.0000 & 295.0000 & 322.5000\end{array}$

$\begin{array}{llllll}\text { (SU) } & 5.9000 & 5.5000 & 5.7625 & 16\end{array}$

umhos $(\mathrm{cm}$ ) $666.0000 \quad 502.0000 \quad 556.7500$

(F) $67.0000 \quad 59.0000 \quad 61.0000 \quad 7$

(NTU) $100.0000 \quad 2.9000 \quad 32.4750 \quad 4$

(ug/L) $<0.1700<0.1700<0.1700 \quad 1$

$\begin{array}{lllll}(\mathrm{pCi} / \mathrm{L}) & 28.2000 & -84.7000 & -8.5571 & 7\end{array}$

$\begin{array}{lllll}\text { (pCi/L) } & 3543.0000 & 863.0000 & 2281.2857 & 7\end{array}$

$\begin{array}{lllll}(\mathrm{pCi} / \mathrm{L}) & 322.0000 & 281.0000 & 301.5000 & 2\end{array}$

$\begin{array}{lllll}\text { (PCiL) } & 322.0000 & 281.0000 & 301.5000 & 2\end{array}$

$(\mathrm{PCi} / \mathrm{L}) \quad 3489.00001567 .0000$
$(\mathrm{~m} / \mathrm{L})<0.0010<0.0010<0.00103$

$(u g / L)<2500.0000<500.0000<1571.4286$

$(\mathrm{ug} / \mathrm{L})<2500.0000<500.0000<1571.4286$

$(u g / L)<2500.0000<500.0000<1571.42867$

$(\mathrm{ug} / \mathrm{L})<2500.0000<500.0000<1571.4286$

$(u / L)<2500.0000<500.0000<1571.42867$

$(u g / L)<2500.0000<500.0000<1571.42867$

$(\mathrm{ug} / \mathrm{L})<2500.0000<500.0000<1571.42867$

(ug/L) $<2500.0000<500.0000<1571.42867$

$(\mathrm{ug} / \mathrm{L})<2500.0000<500.0000<1571.42867$

$(4 \mathrm{~L} / \mathrm{L})<2500.0000<500.0000<1571.42867$

.0000 < $500.0000<1571.4286$

$(u g / L)<2500.0000<500.0000<1571.42867$

$(\mathrm{ug} / \mathrm{L})<2500.0000<500.0000<1571.42867$

(ug/L) $<2500.0000<500.0000<1571.42867$

$\begin{array}{lllllll}\text { (ug/L) } 15000.0000 & 9400.0000 & 11914.2857 & 7\end{array}$

(ug/L) $<5000.0000<1000.0000<2785.71437$

(ug/L) $<5000.0000<1000.0000<2785.71437$ 
Environmental Information Management System

Datu Summary for Sampling Station MW66 04/03/97

Analysis

(Units) Maximum Minimum Average Count

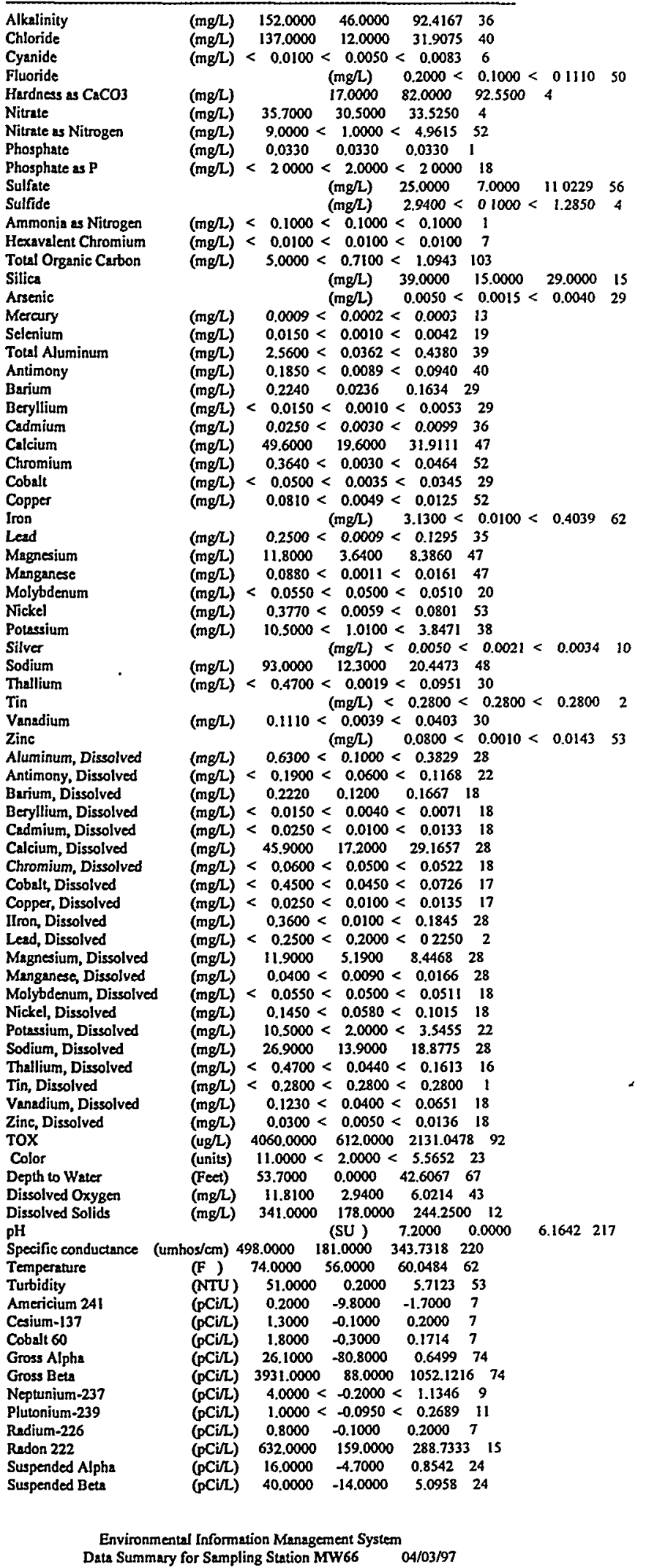




\begin{tabular}{|c|c|c|c|c|c|}
\hline $1 \mathbf{a}$ & i/L) & 1.0000 & -31.8000 & 9.68332 & 24 \\
\hline sets & inl) & 25950000 & 333.0000 & 1554.7917 & 24 \\
\hline$n-99$ & Ci/L) & 3670.0000 & 0.0000 & 1738.7489 & 135 \\
\hline hor & CiL) & $1.0000<$ & $-0.5000<$ & $<\begin{array}{lll}0.1827 & 1\end{array}$ & 10 \\
\hline & b) & $0.0010<$ & $0.0010<$ & 0.00103 & 30 \\
\hline 4 & L) & $1.0000<$ & $0.0350<$ & $=0.3658$ & 6 \\
\hline & L) & $0.1400<$ & $0.0076<$ & $=0.0438$ & 6 \\
\hline & i/L) & $3.5000<$ & $0.0160<$ & $=0.8171$ & 7 \\
\hline $1,1$. & & $<1000.0000$ & 5.0000 & $<402.2727$ & 3 \\
\hline trachloroethe & & $<50$ & 5.0000 & 75.7143 & 7 \\
\hline ane & A) & $<10$ & 1.0000 & $<432.8125$ & \\
\hline & & $<100$ & $<5.0000$ & $<396.6667$ & 36 \\
\hline 1,1 & & $<100$ & 1.0000 & $<<407.7429$ & 935 \\
\hline ene & (L) & $<11.0000<$ & $<10.0000$ & $<102000$ & 5 \\
\hline & /L) & $<100$ & $<5.0000$ & $<424.0816$ & $5 \quad 49$ \\
\hline & L) & $<5$ & $<5.0000$ & $<89$ & 6 \\
\hline & & $<500$ & $<5.0000$ & $<75.7143$ & 7 \\
\hline & & $<11$ & $<10.0000$ & $<10.2000$ & 5 \\
\hline & & $<11$ & $<10.0000$ & $<10.2000$ & 5 \\
\hline & & $<100$ & & $<175.0000$ & 0 \\
\hline & & $<10$ & & $0<1$ & \\
\hline & & $<1$ & $<10$ & $0<1$ & \\
\hline & & $<10$ & $<5$. & 2727 & $7 \quad 33$ \\
\hline & $y)$ & $<10$ & 00 & $<42$ & $6 \quad 49$ \\
\hline & 3/L) & $<5$ & $<5.0$ & $<8$ & 6 \\
\hline & L) & $<1$ & $<10$ & $0<1$ & 6 \\
\hline & L) & $<5$ & 5.0 & $<87.5000$ & 0 \\
\hline & & $<10$ & $<12.0000$ & $<425.6327$ & 49 \\
\hline & $g(L)$ & $<50$ & 5.0000 & $<87.5000$ & 6 \\
\hline & & $<10$ & & $0<1$ & 7 \\
\hline & & & & $0<4$ & 30 \\
\hline & & $<10$ & $<10$. & $<151.4286$ & \\
\hline & & $<1$ & $<50.0000$ & $0<482.3429$ & 9 \\
\hline S & $(L)$ & $<500$. & $<5.0000$ & $<87.5000$ & 6 \\
\hline romethane & (ug/L) & $<500$ & $<5.0000$ & $<87.5000$ & 6 \\
\hline & & & & $<390.5882$ & 234 \\
\hline hloride & & $<t$ & & $<18$ & 6 \\
\hline & & $<50$ & 5.0000 & $<75.7143$ & 7 \\
\hline 6 & $g / L)$ & $<10$ & 5.0000 & $0<437.4583$ & 48 \\
\hline & & & & $<390.5882$ & 234 \\
\hline & & $<100$ & $<50.0000$ & $<482.1429$ & 42 \\
\hline & & & & & 7 \\
\hline & & 10000 & 15.0000 & 4116.1894 & 132 \\
\hline Vinyl Acetate & (ug/L) & $<1000.0000$ & $<10.0000$ & $<157.1429$ & 7 \\
\hline Vinyl Chloride & & $<2000$. & 1.0000 & $<829.8333$ & 348 \\
\hline & $(0 g / 2)$ & $<2000.0000$ & 5.0000 & $<742.0588$ & $8 \quad 34$ \\
\hline
\end{tabular}




\section{DISTRIBUTION}

Argonne National Laboratory

N. Sturchio/L. Heraty

Department of Energy

J. C. Hodges (3)

P. A. Hofmann (ORO)

Environmental Protection Agency

C. Froede (3)

Jacobs Engineering

B. Phillips

D. J. Wilkes

Lockheed Martin Energy Systems

J. L. Clausen (3)

A. F. Diefendorf (ORNL)

J. W. Douthitt (2)

G. K. Jacobs (ORNL)

N. E. Korte (ORNL/GJ)

G. R. Miller (2)

J. W. Morgan

T. E. Phelps (ORNL)

Library

PGDP LMES DMC - RC (2)

Sandia National Laboratory

P. Brady

State of Kentucky

A. Fryar

T. Mullins

T. M. Taylor (4)

U.S. Geological Suryey

M. Rose 